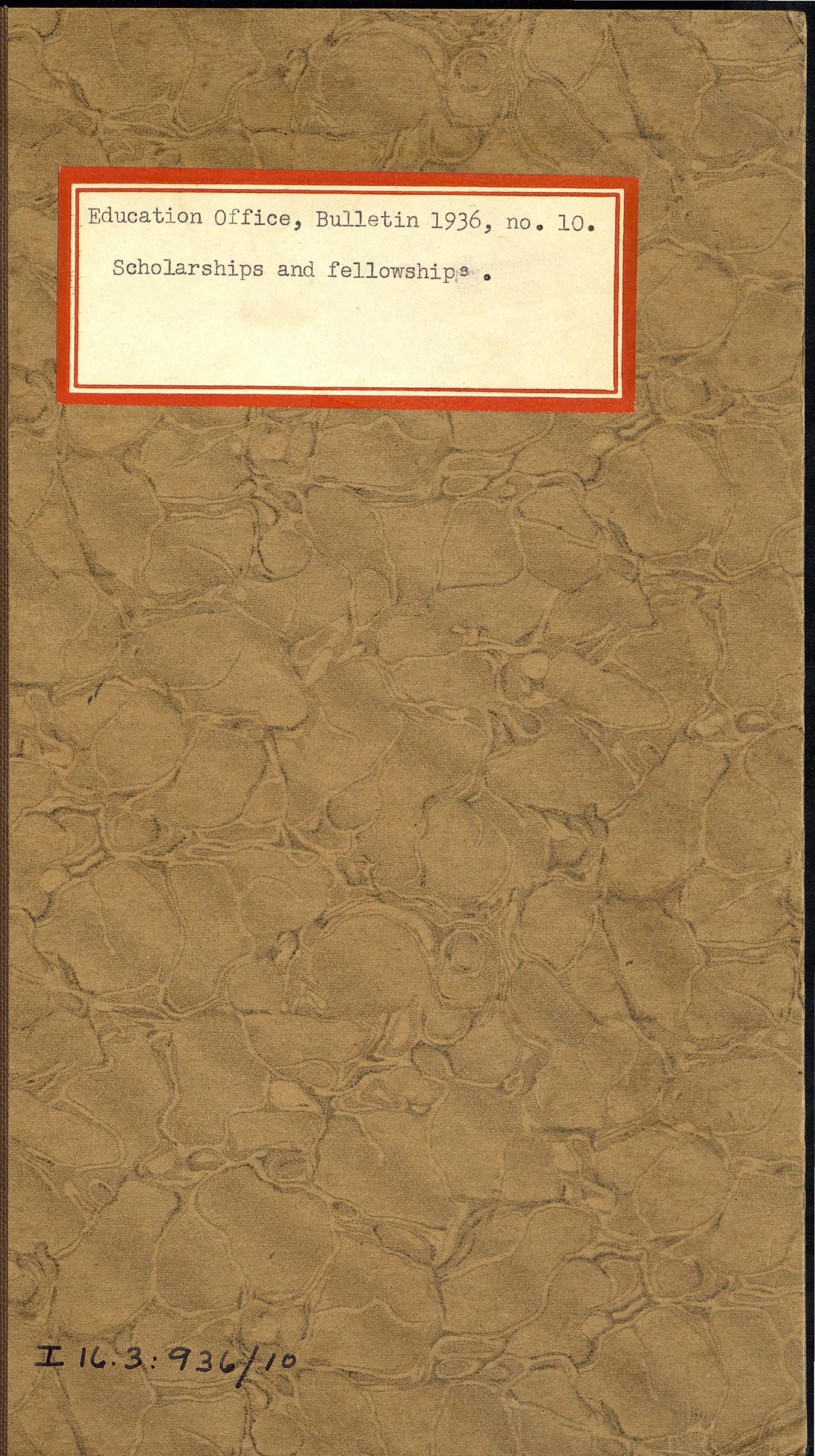




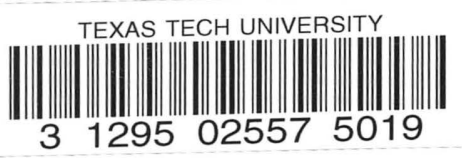




\section{Scholarships and Fellowships}

Available at Institutions of

Higher Education

UNITED STATES DEPARTMENT OF THE INTERIOR OFFICE OF EDUCATION 



\section{UNITED STATES DEPARTMENT OF THE INTERIOR}

Harold L. Ickes, Secretary

OfFice of Education - J. W. Studebaker, Commissioner

\section{Scholarships and Fellowships}

Available at Institutions of Higher Education

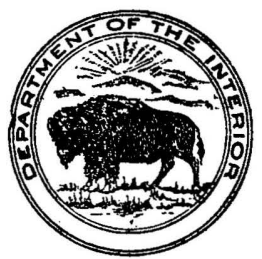

Bulletin, 1936, No. 10

By

ELLA B. RATCLIFFE

Chief Educational Assistant, Division of Higher Education Office of Education

UNITED STATES

GOVERNMENT PRINTING OFFICE

WASHINGTON : 1936

G36:20

For sale by the Superintendent of Documents, Washington, D. C.

Price 15 cents

\section{LIBRAPY}

TEXAS TECHNOLOOIOAL COLLEGE

$$
\text { LUBBOCK TEXAS }
$$





\section{CONTENTS}

Foreword

Introduction

List of references on scholarships and fellowships

Part I.-Scholarships and fellowships available at institutions of higher education, 1934-35 (table 1)

Part II.-State scholarships

For World War orphans._.....

For World War veterans.

Scholarships and fellowships authorized by institutional boards of trustees

Part III.-Scholarships and fellowships available at State-supported institutions of higher education, 1934-35

Table 2.-Scholarships at State-supported universities and colleges.-

Table 3.-Fellowships at State-supported universities and colleges_--

Table 4.-Scholarships and fellowships at State-supported universities and colleges designated for study in special fields.

Table 5.-Scholarships available at State-supported teachers colleges and normal schools

Part IV.-Scholarships and fellowships available at municipally supported institutions of higher education, 1934-35

City scholarships.

Table 6.-Scholarships at municipally supported universities and colleges

Table 7.-Fellowships at municipally supported universities and colleges

Table 8.-Scholarships and fellowships at municipally supported universities and colleges designated for study in special fields.....-

Part V.-Scholarships and fellowships available at privately endowed higher educational institutions, 1934-35.

Table 9.-Scholarships at privately endowed universities and

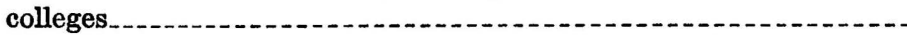

Table 10.-Fellowships at privately endowed universities and colleges. . . . . . .

Table 11.-Scholarships and fellowships at privately endowed universities and colleges designated for study in special fields.

Table 12.-Scholarships and fellowships at privately supported teachers colleges and normal schools.

Table 13.-Scholarships at independent privately endowed technical and professional schools

Art

Engineering -

Medicine

Music 
Part V.-Scholarships and fellowships available at privately endowed higher educational institutions, 1934-35-Continued.

Table 13.-Scholarships at independent privately endowed technical and professional schools-Continued.

Osteopathy

Pharmacy

Social wor

Theology

Table 14.-Fellowships available at independent privately endowed technical and professional schools

Art

Engineering

Medicine

Music

Osteopathy

Pharmacy

Social work

Theology 


\section{FOREWORD}

At the present time particularly, when a college education is made difficult for so many because of financial drawbacks, it is important to bring to the attention of students the opportunities for assistance offered by means of scholarships and fellowships. Information as to how students may be aided is in constant demand. A bulletin of the Office of Education published in 1931 set forth the offerings then available. But these offerings change over a period of years, as scholarships are withdrawn or invested funds decline in value. This bulletin attempts to bring the information regarding scholarship and fellowship offerings up to date. A number of other studies, more limited in scope, have been made recently, and these also are listed. It is believed that this information will be appreciated by the thousands of students who may be eligible to receive scholarships or fellowships.

Bess Goody koontz, Assistant Commissioner. 



\title{
SCHOLARSHIPS AND FELLOWSHIPS
}

\author{
Available at Institutions of Higher Education \\ INTRODUCTION
}

$T_{\text {second which has been made by the United States Office of }}^{\text {HIS COMPILATION of scholarships and fellowships is the }}$ Education. The first compilation was published in 1931 and treated the subject in a manner similar to that used in the present bulletin. Information of this type, however, needs frequent revision, as changes are constantly taking place in the form of student aid represented by scholarships and fellowships, existing funds undergoing modification, and new funds being created.

Of the many thousands of scholarships and fellowships offered, a great number are individual grants awarded on the basis of specific requirements. A compilation which attempted to indicate these requirements and to give exact information about each scholarship and fellowship would require so much time in preparation that much of the information would be out of date almost before it could be published. Several compilations of fellowships made by other agencies have detailed individual grants, but in a bulletin intending to furnish current information and setting out to cover the whole field of scholarship and fellowship awards, the most that can be done, in view of the vast number of grants, is to indicate the institutions at which scholarships and fellowships are available and to give brief statistical data concerning them. This plan has been used in the present bulletin, except in the case of State scholarships for which there is given a brief résumé of the legal provisions and institutional requirements for their award. INFORMATION ON THE SPECIFIC REQUIREMENTS FOR THE SCHOLARSHIPS AND FELLOWSHIPS GIVEN BY ANY INSTITUTION MAY BE OBTAINED BY WRITING DIRECTLY TO THE INSTITUTION ITSELF.

No attempt has been made in this bulletin to indicate the scholarships and fellowships available for foreign study, as this has been done periodically for some years by another organization, the Institute of International Education, to which reference is later made.

The data for individual institutions contained in the tables in this bulletin were obtained by means of a questionnaire, a copy of which 
was sent to all of the institutions of higher learning-1,662-listed in the Educational Directory (part III), 1935, of the Office of Education. Although a large number of institutions - 674-are included in the tables, these are not all that grant scholarships and fellowships, as 700 institutions either did not answer the questionnaire or else gave incomplete information. Practically all of the larger institutions, both publicly and privately supported, answered the questionnaire. Two hundred and eighty-eight institutions reported that they granted neither scholarships nor fellowships. The institutions that failed to report or reported that they had no scholarship funds were very largely those at which either no tuition, or very little tuition, is charged. State teachers colleges and normal schools, municipally supported junior colleges, and independent theological schools constituted the majority of these institutions.

A copy of the questionnaire on which the data in the tables were based is appended to the bulletin.

The terms "scholarship" and "fellowship" are used somewhat interchangeably, but grants for undergraduate study are usually called scholarships, while those for graduate study are called fellowships and are usually, but not always, given for study in a specified field. This common distinction is observed in the present bulletin.

\section{DIVISIONS OF THE BULLETIN}

The bulletin is divided into six parts, as follows:

Introduction.

Part I.-Summary of the statistical data contained in Parts II, III, IV, and V.

Part II.-State scholarships.

Part III.-Scholarships and fellowships available at State-supported higher educational institutions, 1934-35.

Part IV.-Scholarships and fellowships available at municipally supported institutions, 1934-35.

Part V.-Scholarships and fellowships available at privately endowed institutions, 1934-35.

\section{OTHER PUBLICATIONS DEALING WITH SCHOLARSHIPS AND FELLOWSHIPS}

In addition to the previous publication on scholarships and fellowships issued by the Office of Education, Bulletin 1931, No. 15, there have been other studies dealing with the subject. Several of these have listed fellowships and other funds for advanced work available in all fields of study and research; others have been compilations of scholarships and fellowships for study in a specified field only. In all of these compilations information has been given for individual grants from which one or a number of awards are made. Some of these com- 
pilations are now too old to be of service; those that have been published recently enough to be of current value follow. Appended also are references to circulars of information concerning fellowships granted from funds designated by their donors for study or investigation in specified fields.

\section{BULLETINS AND CIRCULARS LISTING SCHOLARSHIPS AND FELLOWSHIPS}

American Association of University Women. A. A. U. W. fellowships and fellows. Washington, D. C. (1634 I Street NW.), 1935.

A history of fellowships in the association, with brief mention of some of the distinguished women who have held them.

American Students Foundation, Inc. Yearbook, 1934-35. New York, N. Y. (R. K. O. Bldg., Radio City).

Lists of the scholarships and fellowships available in a large number of colleges and universities.

Estate of La Verne Noyes. La Verne Noyes scholarships. Chicago, Ill. (2500 Roosevelt Road.)

Circular of information on scholarships for veterans of the World War and their descendants, available in 1935-36 at the following institutions, to which applicants for scholarships should apply:

Alma College, Alma, Mich.

Amherst College, Amherst, Mass.

Baylor University, Dallas, Tex.

Beloit College, Beloit, Wis.

Bradley Polytechnic Institute, Peoria, Ill.

Carleton College, Northfield, Minn.

Carthage College, Carthage, Ill.

Coe College, Cedar Rapids, Iowa.

College of Wooster, Wooster, Ohio.

Cornell College, Mount Vernon, Iowa.

Cornell University, Ithaca, N. Y.

Denison University, Granville, Ohio.

Doane College, Crete, Nebr.

Drury College, Springfield, Mo.

Eureka College, Eureka, Ill.

Franklin College, Franklin, Ind.

Grinnell College, Grinnell, Iowa.

Howard University (Negro), Washington, D. C.

Illinois College, Jacksonville.

Illinois Wesleyan University, Bloomington.

Indiana University, Bloomington.

Iowa State College, Ames.

Kansas State Agricultural College, Manhattan.

Knox College, Galesburg, Ill.

Lake Forest College, Lake Forest, III.

Lawrence College, Appleton, Wis.

Lewis Institute, Chicago, Ill.

Loyola University, Chicago, Ill.

Michigan State College of Agriculture and Applied Science, East Lansing.

James Millikin University, Decatur, Ill.

Monmouth College, Monmouttr, Ill. 
North Central College, Naperville, Ill.

Northwestern University, Evanston, Ill.

Oberlin College, Oberlin, Ohio.

Oklahoma Agricultural and Mechanical College, Stillwater.

Ottawa University, Ottawa, Kans.

George Peabody College for Teachers, Nashville, Tenn.

Purdue University, Lafayette, Ind.

Shurtleff College, Alton, Ill.

South Dakota State College of Agriculture and Mechanic Arts, Brookings.

State University of Iowa, Iowa City.

Texas Christian University, Fort Worth.

Texas Technological College, Lubbock.

University of Alabama, University.

University of California, Berkeley.

University of Colorado, Boulder.

University of Denver, Denver, Colo.

University of Illinois, Urbana.

University of Kansas, Lawrence.

University of Kentucky, Lexington.

University of Michigan, Ann Arbor.

University of Minnesota, Minneapolis.

University of Missouri, Columbia.

University of Nebraska, Lincoln.

University of North Dakota, Grand Forks.

University of Oklahoma, Norman.

University of Redlands, Redlands, Calif.

University of South Dakota, Vermillion.

University of Southern California, Los Angeles.

University of Texas, Austin.

University of Wisconsin, Madison.

Wabash College, Crawfordsville, Ind.

Washington University, St. Louis, Mo.

Wells College, Aurora, N. Y.

Wheaton College, Wheaton, III.

Scholarships for nurses only:

Teachers College, Columbia University, New York, N. Y.

Institute of International Education. Fellowships and scholarships open to American students for study in foreign countries. Fifth edition. New York, N. Y. (2 West Forty-fifth Street), November 1, 1935.

Lists fellowships and scholarships (part $\mathrm{I}$ ) open to students of American institutions of higher education, and (part II) open only to students affiliated with specified colleges and universities.

Institute of International Education. Opportunities for graduate study abroad open to American students. Administered by the institute. New York (2 West Forty-fifth Street).

American field service fellowships for French universities. Fifteenth annual report, 1934. Administered by the institute.

Institute of Student Aid. Student-Aid. Hartford, Conn.

A monthly magazine which reviews State by State the opportunities for scholarships, fellowships, and other forms of student aid.

Institute of Women's Professional Relations. Fellowships and other aids for advanced work. Compiled by Grace Hays Johnson. Greensboro, N. C. North Carolina College for Women, 1930. (Bulletin no. 3.)

Cumulative supplement, 1933. 
Supplement, October 1935-To be used in connection with Bulletin no. 3, 1930, and supplement of 1933 . New London, Conn. Institute of Women's Professional Relations Research Headquarters, Connecticut College.

A comprehensive compilation, according to subject, of scholarships, fellowships, assistantships, and special grants for advanced work.

John Simon Guggenheim Memorial Foundation. Fellowships for advanced study abroad. New York (551 Fifth Avenue), 1936.

Circular of information and list of fellows for 1935.

BULLETINS AND CIRCULARS RELATING TO INDIVIDUAL FUNDS FOR THE AWARD OF SCHOLARSHIPS AND FELLOWSHIPS IN SPECIAL FIELDS

\section{Biological sciences:}

National Research Council. National research fellowships in the biological sciences. Administered by the council. Washington, D. C., October 1, 1935.

Circular of information and list of fellows and their researches, 1931-35.

\section{Chemistry and related sciences:}

The Lalor Foundation Awards for advanced study and research for the year 1937-38. Wilmington, Del. (Lancaster Pike and Old Baltimore Road).

Mimeographed circular of information.

Economic, political, and social sciences:

The Brookings Institution. Research training fellowships. Washington, D. C. (7.22 Jackson Place).

Circular of information. "The flelds in which the institution is at present best equipped to offer research training are as follows: International economfo relations, agricultural economies, power resources, labor and industry, financial organization, marketing, constitutional law, ajministrative law, tax, budget, and public personnel administration."

Forestry:

Charles Lathrop Pack Forest Education Board. Announcements of fellowships in forestry. Washington, D. C. (1214 Sixteenth Street NW.)

Government:

National Institute of Public Affairs. Graduate scholarships. Announcement of the competition for 30 appointments to internship training in the Federal Government for the academic year 1936-37. Washington, D. C. (Investment Building.)

Humanistic sciences:

American Council of Learned Societies. Grants in aid of research. Washington, D. C. (907 Fifteenth Street NW.)

Circular of information. Researches for which grants are made include: philosophy; philology; literature and linguistics; archaeology and art; musicology; history-cultural and intellectual; and auxiliary sciences.

Library science:

American Library Association, Board of Education for Librarianship. Scholarships, fellowships, and loan funds open to librarians. Mimeograph issued by the board. Chicago, Ill. (520 North Michigan Avenue.)

Lists scholarships and fellowships (1) for American students at colleges and universities in the United States; (2) for American students to study abroad; and (3) for the foreign student to study in the United States or another country foreign to his own. 
Medical sciences:

National Research Council. Announcement of fellowships in the medical sciences by the National Research Council. Washington, D. C., September 1935.

Medicine:

Association of American Medical Colleges. Fellowships, funds, and prizes available for graduate medical work in the United States and Canada. Second edition. Chicago, Ill. (5 South Wabash Avenue), 1934.

Compilation of fellowships and funds listed alphabetically according to the institutions, organizations, or designation of funds allocating the funds.

Physics, chemistry, and mathematics:

National Research Council. Research fellowships in physics, chemistry, and mathematics. Administered by the National Research Council. Washington, D. C., January 1, 1936.

Contains information for applicants and a list of fellows and titles of their researches.

\section{Science and technology:}

National Research Council. Fellowships and scholarships for advanced work in science and technology. Third edition. Compiled by Callie Hull and Clarence J. West. Washington, D. C., 1934.

A descriptive list of fellowships and scholarships for advanced work in science and technology by Institutions alphabetically arranged. The index lists the scholarships and fellowships which have distinctive names, and groups those which are restricted to particular sciences.

Funds available in the United States for the support and encouragement of research in science and its technologies. Third edition. Compiled by Callie Hull and Clarence J. West. Washington, D. C., 1934.

Information is presented concerning funds available fer the encouragement and support of research in the form of medals, prizes, grants, and institutional funds.

Social work:

American Association of Social Workers. Social work fellowships and scholarships for 1935-36. New York. (130 East Twenty-second Street.)

Compilation of fellowships and scholarships granted by (1) institutions which are members of the American Association of Schools and Social Workers, and (2) other universities and agencies

Social Science Researah Council. Research training fellowships and grantsin-aid of research in the social sciences, including economics; social, economic, and political history; political science; social psychology, sociology; cultural anthropology; statistics; and social aspects of related disciplines. New York. (230 Park Avenue.)

Circular of information for applicants. 
PART I: SUMMARY OF THE STATISTICAL DATA CONTAINED IN PARTS II, III, IV, AND V

TABLE 1.- SCHOLARSHIPS AND FELLOWSHIPS AVAILABLE AT INSTITUTIONS OF HIGHER EDUCATION, 1934-35 STATE-SUPPORTED INSTITUTIONS

\begin{tabular}{|c|c|c|c|c|c|c|}
\hline \multirow[b]{2}{*}{ Type of institution } & \multicolumn{3}{|c|}{ ScHOLARSHIPS } & \multicolumn{3}{|c|}{ FELLOWSHIPS } \\
\hline & $\begin{array}{l}\text { Institu- } \\
\text { tions re- } \\
\text { porting }\end{array}$ & $\begin{array}{c}\text { Number of } \\
\text { scholar- } \\
\text { ships }\end{array}$ & $\begin{array}{l}\text { Amount of } \\
\text { scholarship } \\
\text { funds }\end{array}$ & $\begin{array}{l}\text { Institu- } \\
\text { tions re- } \\
\text { porting }\end{array}$ & $\begin{array}{c}\text { Number of } \\
\text { fellow- } \\
\text { ships }\end{array}$ & $\begin{array}{l}\text { Amount of } \\
\text { fellowship } \\
\text { funds }\end{array}$ \\
\hline 1 & 2 & 8 & 4 & s & 6 & 7 \\
\hline $\begin{array}{l}\text { University, college, junior col- } \\
\text { lege, professional or technical } \\
\text { school. } \\
\text { Teachers college or normal } \\
\text { school }\end{array}$ & 88 & $\begin{array}{r}14,492 \\
1,602\end{array}$ & $\begin{array}{r}\$ 1,416,679 \\
78,970\end{array}$ & $\begin{array}{r}89 \\
5\end{array}$ & $\begin{array}{r}2,531 \\
38 \\
\end{array}$ & $\begin{array}{r}\$ 945,467 \\
9,560 \\
\end{array}$ \\
\hline Total & 139 & 16,094 & $1,495,649$ & 64 & 2,569 & 955,027 \\
\hline \multicolumn{7}{|c|}{ MUNIOIPALLY SUPPORTED INSTITUTIONS } \\
\hline $\begin{array}{l}\text { University, college, or junior } \\
\text { college. }\end{array}$ & 40 & 1,745 & $\$ 69,821$ & 6 & 60 & $\$ 32,823$ \\
\hline \multicolumn{7}{|c|}{ PRIVATELY SUPPORTED INSTITUTIONS } \\
\hline 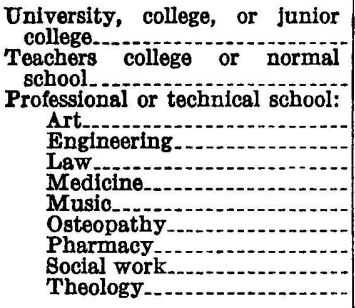 & $\begin{array}{r}394 \\
14 \\
3 \\
3 \\
14 \\
4 \\
5 \\
9 \\
1 \\
8 \\
1\end{array}$ & $\begin{array}{r}44,476 \\
407 \\
11 \\
1,779 \\
23 \\
42 \\
304 \\
22 \\
76 \\
26 \\
1,703\end{array}$ & $\begin{array}{r}\$ 6,481,539 \\
69,108 \\
7,850 \\
850,468 \\
1,175 \\
11,275 \\
69,360 \\
3,300 \\
10,060 \\
3,000 \\
310,477\end{array}$ & $\begin{array}{r}84 \\
1 \\
1 \\
7 \\
0 \\
2 \\
1 \\
2 \\
2 \\
1 \\
10\end{array}$ & \begin{tabular}{r|}
2,341 \\
26 \\
7 \\
493 \\
0 \\
4 \\
178 \\
8 \\
19 \\
13 \\
79
\end{tabular} & $\begin{array}{r}\$ 1,142,828 \\
10,550 \\
8,500 \\
152,010 \\
0 \\
5,800 \\
200,000 \\
1,740 \\
11,500 \\
9,000 \\
47,700\end{array}$ \\
\hline Total. & 495 & 48,869 & $7,297,612$ & 120 & 3,168 & $1,589,628$ \\
\hline Grand total & 674 & 66,708 & $8,863,082$ & 190 & 5,797 & $2,577,478$ \\
\hline
\end{tabular}




\section{PART II: STATE SCHOLARSHIPS}

THE STATES of the Union have very generally made it possible for their citizens to obtain higher education at a minimum of outlay to themselves. Not only, as a rule, are the tuition or other instructional charges at State colleges and universities made moderate for students resident within the State, but in 20 States additional financial aid is accorded State students by means of scholarships which are made available, so far as their numbers permit, to any citizens of the State who can meet the legal and institutional requirements. The requirements sometimes make it incumbent upon the holders to pursue designated courses of study, such as in agriculture or in education, that will fit them to enter a specified field of work which the State desires to develop, but more often they leave the holders free to elect courses in accordance with their own desires and needs. One State, Wisconsin, in order to attract students from other States, has provided by law for scholarships to be awarded to nonresident students at the University of Wisconsin. Another State, Michigan, has made provision for the offering of an annual scholarship at the Michigan College of Mining and Technology to each State in the Union, each Province of Canada, each LatinAmerican country, and each outlying part of the United States.

In addition to the scholarships for citizens of the State in general, 35 States and the District of Columbia provide through legislative enactment for the granting of scholarships to World War orphans, 11 States provide scholarships for the veterans themselves, and 4 States provide scholarships for Negro residents to enable them to attend institutions of college grade outside the State where they may be admitted to advanced or professional courses of study not available to them in their own State.

The trend in recent years has been to make scholarship aid available to an increasing number of students. Practically all of the laws granting scholarships to war orphans have been enacted within the past 5 years; in 10 States they were enacted in 1935 . The four States which provide scholarships for Negro students in out-of-State institutions enacted the laws during the past 2 years. On the other hand, North and South Carolina, in 1933, and Arizona, in 1935, repealed their laws providing for general scholarship aid. In the 
two Carolinas the acts not only abolished all State scholarships but required that tuition be paid by all students in the State-supported institutions. In 1933 also the State of Florida suspended the awarding of all State scholarships except those for agricultural students at the University of Florida, although 2 years later it enacted the most liberal law of any State in the Union granting scholarships to the children of World War veterans. Another State, Delaware, which formerly provided 60 scholarships at the University of Delaware, to be given residents who intended to become teachers in the elementary schools of the State, discontinued the practice several years ago, "when it became unnecessary to offer inducement to secure an adequate supply of teachers for these positions."

The State scholarship laws reveal various purposes in their enactment. One purpose, which has grown somewhat less needful in recent years, is that of encouraging students to prepare for teaching positions in the State; another is to train persons for carrying on agricultural pursuits in the State. One State, Vermont, grants 90 scholarships annually to students of medicine, who must agree to practice medicine in the State 1 year for each year the scholarship is held or refund the amount received. The State of Maryland places 129 annual scholarships in engineering at Johns Hopkins University for State students but imposes no obligation upon the holders to engage in the practice of engineering.

The greatest number of State scholarships, however, are given for study in the general field of higher education without reference to training for a specialty. They are awarded, as a rule, to students of good character and ability and are regarded as an investment which will accrue to the benefit of the State as well as of the individual. Excepting those for special classes, such as war orphans, they are usually distributed in equal number to the counties or legislative districts of the State and are awarded on the basis of a competitive examination, or of standing in the high-school graduating class, or of scholarship combined with need. Most of these scholarships release the holders from the payment of certain fees during the length of the course of study, but others are limited to 1 or 2 years. They range in value from $\$ 50$ to $\$ 350$ a year.

The laws commonly assign the scholarships to the State-supported institutions; but in Louisiana, Maine, Maryland, New York, Ohio Pennsylvania, Rhode Island, and Vermont, State scholarships are also placed at privately endowed institutions.

A brief résumé of the legal provisions and of the regulations which the institutions have adopted for the award of State scholarships are given in the following paragraphs: 


\title{
SCHOLARSHIPS GIVEN UNDER AUTHORITY OF STATE LAW
}

\author{
For State Residents in General \\ CONNEOTIOUT
}

State Teachers College, New Britain, and State normal schools at Danbury, Now Haven, and Willimantic.-One scholarship at any one of the institutions for each town in the State having average annual receipts from taxation of $\$ 39,000$ or less. Appointments are made upon the recommendation of the board of education of the town. Scholarships provide living expenses not to exceed $\$ 300$ annually for each student. About 60 scholarships are available. Holders are required to teach in a 1- or 2-teacher school in one of the towns for a period of 2 years after graduation.

\section{FLORIDA}

University of Florida.-County agricultural scholarships: One for each county, offered and provided for at the discretion of the board of county commissioners of each county. Annual value represents a sum sufficient to pay for board in the dining hall and room in the dormitory during the period necessary for the pursuit of a full course of study. Awarded on basis of competitive examination. Appointees must sign a certificate agreeing, if capable and otherwise qualified, to engage in agricultural pursuits in the State.

\section{ILLINOIS}

University of Illinois.-(1) County scholarships: One scholarship for each county in the State. Annual value, $\$ 70$ to $\$ 152.50$, depending upon the college or school in which the student enrolls. Awarded on basis of competitive examination. Candidates must be at least 16 years of age and must be able to meet in full requirements for admission to the university. Open to men and women. Tenure, 4 years.

(2) General assembly scholarships: One nomination annually by each member of the general assembly. Annual value, $\$ 70$ to $\$ 152.50$, depending upon the college or school in which the student enrolls. Candidates must be able to meet in full requirements for admission to the university. They must be at least 16 years of age and must be residents of the districts represented in the general assembly by the members who nominate them. Tenure, 4 years.

State teachers colleges.-Scholarships for recognized high schools: For use at any of the State teachers colleges-Fiastern Illinois State Teachers College, Charleston; Ilinois State Normal University, Normal; Northern nlinois State Teachers College, De Kalb; Southern Illinois State Normal University, Carbondale; Western Hlinois State Teachers College, Macomb. Awarded annually to each recognized 4-year high school as follows: High schools with enrollment of fewer than 500 studends, 1 scholarship; high schools. with enrollment of 500 to 1,000 students, 2 scholarships; high schools with enrollment of more than 1,000 students, 3 scholarships. Scholarships entitle holders to gratuitous instruction, including tuition, matriculation, incidental or any other fees for 4 years. Applicants must rank in the upper quarter of their high-school graduating classes and must signify their intention to prepare to teach in the public schools of Illinois.

\section{INDIANA}

Indiana University.-County scholarships: Not less than two appointments for each county in the State made annually by the board of trustees of the university and the faculty, nominations to be made on the basis of scholarship and superior mental ability. Appointments may be made both from students 
eligible to enter the university and students already in attendance. Scholarships exempt holders from payment of any contingent fees. Tenure, 1 year. Purdue University.-County scholarships: Not fewer than two appointments for each county in the State made annually by the trustees of Purdue University upon recommendation of the university faculty. The recommendations are based upon such tests, examinations, and records as may be prescribed by the faculty. Scholarships exempt holders from payment of tuition and incidental fees.

Ball State Teachers College, Muncie, and Indiana State Teachers College, Terre Haute.-County scholarships: Two appointments to each State teachers college for each county in Indiana, made annually by the State teachers college board. Exempt holders from payment of contingent fees (amounting in 1935-36 to $\$ 66$ for the school year). Appointments are made from among the candidates recommended by the high-school principals of each county, based on qualities which predict success in teaching, such as scholarship, health, personality, leadership, and character.

\section{LouisLana}

Louisiana State University, Baton Rouge; Louisiana Polytechnic Institute, Lafayette; Louisiana State Normal College, Natchitoches; Southwestern Louisiana Institute, Ruston.-The police jury of each parish in the State is empowered by law to select one beneficiary and the city council of New Orleans to select one beneficiary from each representative ward of the city and to defray their expenses at one of the above-named State institutions. Such expense must not exceed $\$ 350$ annually.

Louisiana State University.-The police jury of each parish in the State has the right to select a graduate from each of the high schools in the parish and to defray his expenses at the university, provided he obligates himself to pursue the course in agriculture, to remain in the institution until he graduates, and then to work in his home parish for at least 2 years after graduation in some capacity connected with agriculture. The amount allowed for expenses covers such items as board, fees, cost of books, etc., and is usually $\$ 300$ or $\$ 400$ a year.

Louisiana Polytechnic Institute, Southwestern Louisiana Institute, and Louisiana State Normal College.-The police jury of each parish in the State is empowered to delegate from the parish to one of the above-named institutions one woman student, and the city of New Orleans is empowered to delegate from each ward of the city to any one of the institutions one woman student and to defray the expense of their attendance at the institution, to an amount not to exceed $\$ 250$ a year. The beneficiaries are selected upon the basis of competitive examination. They must be residents of the parishes or wards and must be students who have not the means for defraying the whole cost of attendance at the institutions.

Tulane University of Louisiana, New Orleans (a privately supported institution).-Each State senator and each State representative has the right to nominate one beneficiary to attend Tulane University or H. Sophie Newcomb College (the woman's college), free of expense for tuition or other college fees. At the university the beneficiary may be enrolled in the college of arts and sciences and (at present) the college of engineering. The appointees must meet entrance and other requirements of the university and of the college.

\section{MAINE}

Bates College, Lewiston (a privately supported institution).-State scholarships: Ten, at annual value of $\$ 50$. Award in hands of the Governor. Preference is given to children of those who have borne arms in defense of their country and always to students who are needy and worthy.

$75014^{\circ}-36-2$ 


\section{MARYLAND}

Blue Ridge College, ${ }^{1}$ New Windsor (a privately supported institution).--State scholarships: One for each senatorial district. Furnish free tuition. Tenure, 4 years. Open to men and women. Awarded upon basis of competitive examination. Applicants must be unable to pay for their college expenses without assistance.

Johns Hopkins University, Baltimore (a privately supported institution).-

(1) State scholarships (ordinary): For use in the school of engineering. One hundred and twenty-nine scholarships. Apportioned to the counties of the State and to the legislative districts of Baltimore. Six are scholarships at large, open to residents of the State without reference to the county or legislative district in which they reside. Applicants must be deserving and unable to pay for their college education without assistance. They must satisfy the university entrance requirements by means of an examination. Holders are entitled to free tuition, free textbooks, and exemption from laboratory fees. Appointments are for 1 year but may be renewed for the length of the course. Three of the scholarships are offered to Maryland graduates of each of the following colleges: Loyola College, Baltimore; University of Maryland, College Park; Mount St. Mary's College, Emmitsburg; St. John's College, Annapolis; Washington College, Chestertown; Western Maryland College, Westminster. Award of these scholarships is made without reference to ability of the applicants to pay the fees and is solely on the basis of merit as certified by the presidents of the colleges.

(2) Senatorial scholarships: Held in addition to the State scholarships. In each county and in each legislative district the senator has the privilege of recommending one of the scholarship holders for the senatorial scholarship, which consists of $\$ 200$ or other provision for defraying the expense of board and lodging.

St. John's College, Annapolis (a privately supported institution).-(1) Senatorial scholarships: One for each county in the State and one for each legislative district of Baltimore. Award based on competitive examination. Cover tuition, board, and room rent. Tenure, 4 years.

(2) Tuition scholarships: One for each county in the State and one for each legislative district of Baltimore. Award based on competitive examination. Tenure, 4 years.

Only applicants who are unable to pay the necessary college expenses may receive appointments to either of these scholarships.

St. Mary's Female Seminary, ${ }^{1}$ St. Marys City (a privately supported institution).-One scholarship for each county of the State and one for each legislative district of Baltimore. Awarded on basis of competitive examination. Tenure, 4 years. Only applicants unable to pay the necessary college expenses are eligible for appointment.

Washington College, Chestertown (a privately supported institution).-(1) Two scholarships for male students from each county of the Eastern Shore. Annual value covers tuition, board, room rent, and textbooks. Appointments are made by the orphan's court of the county, except that in Kent, Queen Anne's, and Dorchester Counties the award is made by the appropriate State senator after competitive examination given by the college. Tenure, 4 years. Only needy students are eligible.

(2) A scholarship for one male student in each senatorial district on the Western Shore. Annual value covers tuition, board, room rent, and textbooks. Tenure, 4 years. Assigned by the board of education of the sena-

\footnotetext{
1 Junior college.
} 
torial district, by and with the consent of the senator from that district. In the city of Baltimore the appointment is made by the senator in each district after competitive examination given by the college. Only needy students are eligible.

(3) The board of education of each county on the Western Shore is empowered to send one male student to the college, who is entitled to receive free tuition and free textbooks. Only needy students are eligible.

Western Maryland College, Westminster (a privately supported institution).One scholarship for a young man and one for a young woman from each county of the State and from each legislative district of Baltimore. Annual value covers tuition and board. Appointments made by appropriate State senators only after competitive examination. Only applicants who are unable to pay their own expenses are eligible. Scholarship tenure, 4 years.

State scholarships for Negroes, to attend college outside the State of Maryland.-The main purpose of these scholarships is to give the benefit of college, medical, law, or other professional courses to colored youth of the State who do not have facilities in the State for such courses. Value of scholarship, $\$ 200$. Candidates must be bona-fide residents of Maryland, must maintain satisfactory standard in deportment, scholarship, and health after the award is made, and must meet all additional charges beyond the amount of the scholarship to enable them to pursue their studies. The Maryland Commission on Higher Education of Negroes, Baltimore, Md., administers these scholarships.

Note: The laws of Maryland provide also for scholarships to Charlotte Hall School, Charlotte Hall, a private secondary school for boys, and Maryland Institute, Baltimore, a private school of art and design.

\section{MASSACHUSETTS}

There are no State scholarships maintained by Massachusetts except those given to the children of World War veterans (see p. 22), but the department of education makes an annual appropriation for the State teachers colleges, the amount being divided up somewhat on a per-pupil basis among the 10 State teachers colleges and administered by the president in each case as direct aid to needy students.

\section{MICHIGAN}

Michigan College of Mining and Technology.-United States and foreign scholarships. In accordance with provisions made by the State legislature, the board of control of the college has established for each State in the Union, each Province of Canada, each Latin-American country, and each territorial possession of the United States, an annual scholarship entitling the holder to the privileges of the college without payment of matriculation and tuition fees.

\section{MISSOURI}

Tuition for Negro college students at institutions outside the State.Negro students may have their tuition paid at some standard college or university not located in Missouri, provided they have completed at least 60 hours of standard college work and are not pursuing courses in such college or university leading to the A. B. degree in liberal arts or the B. S. degree in education, but are pursuing courses not offered at Lincoln University but offered at the University of Missouri. The total amount paid for a student may not exceed the difference between the registration and incidental fees charged by the University of Missouri to resident students and by the institution attended for similar courses, and may not exceed $\$ 100$ for a school year of 9 months for undergraduate study, and $\$ 150$ for a school year of 9 months for graduate study. 


\section{NEW JERSEY}

Rutgers University (the land-grant college of the State).-Forty tuition scholarships, which exempt residents of New Jersey from the payment of tuition, distributed among the counties in approximate proportion to the number of assemblymen. Students are admitted to such scholarships on recommendation of the superintendent of schools in each county after having qualified for admission.

\section{NEW YORK}

University of the State of Now York (State education department, Albany).University scholarships: For use in the approved institutions of higher learning in the State. Seven hundred and fifty available annually; five to each county for each assembly district therein, except that in a city having a population of $1,000,000$ or more, 5 scholarships are awarded to such city for each assembly district therein, and are awarded to the city at large, without regard to county boundaries. Annual value, $\$ 100$. Tenable 4 years. Collegeentrance diplomas constitute, in part, basis for award. Such diplomas are issued only to those who have been pupils in the registered secondary schools of the State for at least half of the school year immediately preceding the date of award of the diploma; who have attended such schools for at least 3 school years (except in unusual and extraordinary cases); who have completed within 6 years of enrollment an approved 4-year high-school course (certain exceptions noted); who have passed the prescribed regents' examinations with an average standing of 75 percent; and who file in the State education department, not later than July 5 next succeeding the completion of the course of study, principal's certificate of good moral character, a formal application for the scholarship on a blank furnished by the department, and evidence of citizenship and residence in the State of New York. Candidates are required to pass comprehensive examinations in certain prescribed subjects. Awards are made in the order of merit.

University scholarships are available for use at the following institutions:

Adelphi College, Garden City.

Alfred University, Alfred.

Bard College, Annandale.

Brooklýn College, Brooklyn.

Buffalo State Teachers College, Buffalo.

Canisius College, Buffalo.

Clarkson College of Technology, Potsdam.

Colgate University, Hamilton.

City College, New York.

College of Mount St. Vincent, New York.

College of New Rochelle, New Rochelle.

College of the Sacred Heart, Manhattanville.

College of St. Rose, Albany.

Columbia University, New York.

Cooper Union Institute of Technology, New York.

Cornell University, Ithaca.
D'Youville College, Buffalo.

Elmira College, Elmira.

Fordham University, New York.

Good Counsel College, White Plains.

Hamilton College, Clinton.

Hartwick College, Oneonta.

Hobart College, Geneva.

Houghton College, Houghton.

Hunter College of the City of New York, New York.

Ithaca College, Ithaca.

Juilliard School of Music, New York.

Keuka College, Keuka Park.

Long Island University, Brooklyn.

Manhattan College, New York.

Marymount College, Tarrytown.

Nazareth College, Rochester.

New York State College of Forestry (Syracuse University), Byracuse.

New York State College for Teachers, Albany.

New York University, New York. 
Niagara University, Niagara Falls.

Notre Dame College of Staten Island, Grymes Hill, S. I.

Polytechnic Institute of Brooklyn, Brooklyn.

Rensselaer Polytechnic Institute, Troy.

Russell Sage College, Troy.

St. Bernard's Seminary and College, Rochester.

St. Bonaventure's College, St. Bonaventure.

St. Francis College, Brooklyn.

St. John's University, Brooklyn.

St. Joseph's College for Women, Brooklyn.
St. Joseph's Seminary and College, New York.

St. Lawrence University, Canton.

Sarah Lawrence College, Bronxville.

Skidmore College, Saratoga Springs.

Syracuse University, Syracuse.

Union University, Schenectady.

University of Buffalo, Buffalo.

University of Rochester, Rochester.

Vassar College, Poughkeepsie.

Wagner Memorial Lutheran College, Staten Island.

Webb Institute of Naval Architecture, New York.

Wells College, Aurora.

William Smith College, Geneva.

Yeshiva College, New York.

Industrial teachers' scholarships.-Twenty-five available annually. Entitle holders to receive $\$ 250$ for 1 year while in attendance upon vocational department of a State normal school. Only men and women who possess satisfactory educational qualifications, in the opinion of the commissioner of education, and who have had at least 5 years of successful experience in a trade or industrial occupation are eligible.

Cornell University.-State tuition scholarships (in addition to university scholarships). Equal to the number of assembly districts in the State. Annual value, reduction of $\$ 200$ from the regular tuition in any college of the university. Tenable 4 years. Award made after student has satisfied regular entrance requirements and registered as a student of the university. Given in consideration of superior ability and scholarship.

For information concerning all of the above New York State scholarships, application should be made to the commissioner of education, Albany, N. Y.

оHIO

Wilberforce University, Wilberforce (a privately supported institution for Negroes).- State scholarships: Each senator and representative of the general assembly of the State may designate one or, under certain circumstances, more than one youth, resident in his district, to receive State scholarships. Such students are entitled to enter the combined normal and industrial department (the only State-aided division of the university) free from the payment of tuition and charges for room rent, heat, and light.

\section{OKLAHOMA}

Oklahoma Military Academy, Claremore.-Each senator of the State is authorized to appoint two cadets from his senatorial district, and each representative of the State is authorized to appoint one cadet from his representative district, to attend the Oklahoma Military Academy free from the payment of tuition.

Colored Agricultural and Normal University, Langston.-State scholarships: Twenty-five; annual value, $\$ 100$; tenure, 2 years. Awards made on basis of competitive examination, which is open to boys in each county of Oklahoma who have completed the common-school course and received, or are entitled to receive, their diplomas. Not more than two scholarships may be awarded to students in any one county. Holders are obligated to become actual farmers for at least such period of time as they have been students of the institution. 
Out-of-State tuition for Negro students.-(1) Bona fide residents of Oklahoma of 5 years' standing, of good character and ability, who have completed 2 years of college work, and who desire to pursue courses of study which are not given in institutions in Oklahoma provided for such persons and who are excluded through constitutional provisions from attending the University of Oklahoma or other State-supported institutions of Oklahoma offering such courses, may have their tuition and fees paid by the State at educational institutions outside the State where such courses are given. In addition, they may be allowed transportation costs to such institutions. The total expense incurred may not exceed $\$ 250$ a year for each student. The State board of education, Oklahoma City, is charged with the administration of the funds.

(2) Students who have completed a course of study in State-supported educational institutions of Oklahoma and have received or will receive a degree which does not have a similar value as the same degree from the University of Oklahoma, or other State-supported educational institutions of Oklahoma from which such students are by constitutional provisions excluded, are entitled to attend institutions outside the State which confer degrees of similar value to those in Oklahoma from which such students are excluded, for the purpose of obtaining such degree, and have their tuition, fees, and transportation paid to an amount not to exceed $\$ 250$ a year for each student.

\section{OREGON}

Oregon State System of Higher Education, Eugene.-The State board of higher education is authorized by law to award scholarships in any institution of higher learning in the State, not to exceed 2 percent of the institution's enrollment; award to be based on intellectual standing and deportment in the school where the applicant has received or is receiving his or her preliminary training, the need of financial assistance, and other qualifications of such nature that the awarding of scholarships will operate not only to the advantage of the applicant but to the people of the State of Oregon. Annual value of scholarship is not to exceed the amount of tuition and other fees at the respective institutions. Offered annually and available to both men and women.

Under authority of the foregoing, State scholarships (waiver of fees) are offered (in 1935-36) at the institutions composing the Oregon State System of Higher Education, as follows:

University of Oregon, Eugene:

53 resident scholarships, at annual value of $\$ 54$.

2 nonresident scholarships, at annual value of $\$ 174$.

Oregon State Agricultural College, Corvallis:

54 resident scholarships, at annual value of $\$ 54$.

3 nonresident scholarships, at annual value of $\$ 174$.

Eastern Oregon Normal School, La Grande:

7 scholarships, at annual value of $\$ 18$.

Oregon Normal School, Monmouth:

17 scholarships, at annual value of $\$ 18$.

Southern Oregon Normal School, Ashland:

7 scholarships, at annual value of $\$ 18$.

\section{PENNSYLVANIA}

State scholarships.-Eight to Philadelphia County, six to Allegheny County, two to Luzerne County, and one to each of the remaining counties in the State. Valid in any approved college or university in the State. Annual value, $\$ 100$. Tenable 4 years. Award made on basis of competitive examination given under supervision of State board of education. Information regarding examination obtainable from the State department of public instruction at Harrisburg. 
State scholarships may be used at the following institutions:

Albright College, Reading. Allegheny College, Meadville.

Beaver College, Jenkintown.

Bryn Mawr College, Bryn Mawr.

Bucknell University, Lewisburg.

Carnegie Institute, Pittsburgh.

Cedar Crest College, Allentown.

College Misericordia, Dallas.

Dickinson College, Carlisle.

Drexel Institute, Philadelphia.

Dropsie College, Philadelphia.

Duquesne University, Pittsburgh.

Elizabethtown College, Elizabethtown.

Franklin and Marshall College, Lancaster.

Geneva College, Beaver Falls.

Gettysburg College, Gettysburg.

Grove City College, Grove City.

Haverford College, Haverford.

Immaculata College, Immaculata.

Juniata College, Huntingdon.

Lafayette College, Easton.

LaSalle College, Philadelphia.

Lebanon Valley College, Annville.

Lehigh University, Bethlehem.

Lincoln University, Lincoln University.

Marywood College, Scranton.

Mercyhurst College, Erie.

Moore Institute of Art, Science, and Industry, Philadelphia.

Moravian College and Theological Seminary, Bethlehem.
Moravian College for Women, Bethlehem.

Mount Mercy College, Pittsburgh.

Mount St. Joseph College, Philadelphia.

Muhlenberg College, Allentown.

Pennsylvania College for Women, Pittsburgh.

Pennsylvania Military College, Chester

Pennsylvania State College, State College.

Philadelphia College of Pharmacy and Science, Philadelphia.

Rosemont College, Rosemont.

Seton Hill College, Greensburg.

St. Charles' Seminary, Overbrook.

St. Francis College, Loretto.

St. Joseph's College, Philadelphia.

St. Thomas College, Scranton.

St. Vincent College, Latrobe.

Susquehanna University, Selinsgrove.

Swarthmore College, Swarthmore.

Temple University, Philadelphia.

Thiel College, Greenville.

University of Pennsylvania, Philadelphia.

University of Pittsburgh, Pittsburgh.

Ursinus College, Collegeville.

Villa Maria College, Erie.

Villanova College, Villanova.

Washington and Jefferson College, Washington.

Waynesburg College, Waynesburg.

Westminster College, New Wilmington. Wilson College, Chambersburg.

Holders of the State scholarships may also attend the State teachers colleges, provided they take courses leading to the degree of bachelor of science in education. The State teachers colleges are located as follows: Bloomsburg, California, Clarion, East Stroudsburg, Edinboro, Indiana, Kutztown, Lock Haven, Mansfield, Millersville, Shippensburg, Slippery Rock, West Chester, Cheyney Training School for Teachers (Negro), Cheyney.

Pennsylvania State College, Temple University, University of Pennsylvania, University of Pittsburgh.- Senatorial scholarships: Three appointments to each, made annually by each State senator, entitle holders to exemption from the incidental fee of $\$ 100$ a year at Pennsylvania State College and to the tuition in the other three universities. Applicants must meet in full all college-entrance requirements and be enrolled for a 4-year course of study. (These scholarships were established by the board of trustees of the colleges, in accordance with a resolution of the State senate "that each college, university, or other institution of learning receiving appropriations from the Commonwealth shall, for each appropriation period, award to each member of the senate of the general assembly of the Commonwealth three scholarships in a complete course of study at said college, university, or institution.") 


\section{RHODE ISLAND}

Brown University, Providence (a privately supported institution).--State scholarships in education, covering tuition for graduate courses in education pursued by candidates for the degree of master of arts. Also granted for individual courses. Open to men and women. Appointments made by State board of education. The number varies annually, the appropriation to cover being $\$ 5,000$.

Rhode Island College of Pharmacy and Allied Sciences, Providence (a privately supported institution).-State scholarships: Sixteen available annually; value, $\$ 125$. Awarded to worthy students who could not otherwise attend college.

Rhode Island School of Design, Providence (a privately supported institution).-The number of scholarships that may be purchased for $\$ 12,000$ annually. This number varies because the scholarships may be for day or evening classes, and the tuition is larger for day classes. For students who are not able to pay the tuition.

TEXAS

State scholarship.-For the highest ranking graduate of each accredited high school in Texas. Entitles the holder to exemption of tuition fees amounting to $\$ 50$ annually. May be used at any one of the State-supported institutions of higher learning in Texas, as follows:

Agricultural and Mechanical College of Texas, College Station.

College of Mines and Metallurgy, El Paso.

Texas College of Arts and Industries, Kingsville.

Texas State College for Women, Denton.

Texas Technological College, Lubbock.

University of Texas, Austin.

East Texas State Teachers College, Commerce.

Prairie View State College (Negro), Prairie View.

North Texas State /Teachers College, Denton.

Sam Houston State Teachers College, Huntsville.

Southwest Texas State Teachers College, San Marcos.

Stephen F. Austin State Teachers College, Nacogdoches.

Sul Ross State Teachers College, Alpine.

West Texas State Teachers College, Canyon.

John Tarleton Agricultural College, ${ }^{2}$ Tarleton Station.

North Texas Agricultural College, ${ }^{2}$ Arlington.

\section{UTAH}

University of Utah, Salt Lake City.-Normal scholarships: One hundred. For use in the school of education of the university. Annual value, \$25. Tenure, 4 years.

VERMONT

Middlebury College, Middlebury (a privately supported institution).-State scholarships: Sixty (two for each State senator). Appointments made annually by senators of students from their respective counties. Annual value, $\$ 120$; covers tuition and incidental charges. Tenure, 4 years.

Norwich University, Northfleld (the State military school).- State scholarships: One hundred and twenty-five, at annual value of $\$ 120$. Appointments made upon recommendation of the several State senators to bona fide residents of their respective counties. Tenure, 4 years.

\footnotetext{
2 Junior college.
} 
University of Vermont, Burlington.-State scholarships: Ninety, at annual value of $\$ 120$. Three appointments, one of a student pursuing the bachelor of science course in agriculture, are made annually by each State senator. Tenure, 1 year.

State scholarships in medicine: Fifty, at annual value of $\$ 100$. Applicants must be in need of financial assistance and must have resided in Vermont for 2 consecutive years preceding enrollment. Tenure, 4 years. Beneficiaries must agree to practice medicine in the State of Vermont 1 year for each year the scholarship is held or to refund the amount received.

\section{VIRGINIA}

College of William and Mary, Williamsburg.- State teachers scholarships: One hundred and thirty-two. Offered to students who wish to prepare themselves to teach in the public schools of Virginia. Entitle holders to credit on college expenses amounting to $\$ 37.50$ a semester on fees and $\$ 9$ a semester on board. Scholarships may be held until the dean of the school of education rules otherwise.

University of Virginia, Charlottesville.-State teachers scholarships. Given in the department of education. Thirty annually, 20 with a value of $\$ 200$ and 10 with a value of $\$ 100$. Candidates must be Virginians in need of financial assistance, and must pledge themselves to teach or engage in some form of public-school work in Virginia for at least 2 years, or, failing this, to repay the university the full value of the scholarships.

Virginia Military Institute, Lexington.-Not fewer than 50 State cadets, 1 from each senatorial district and others from the State at large, are received at the institute free of the expense of board and tuition. They must furnish evidence that they are unable to pay such expenses. Young men between the ages of $\mathbf{1 6}$ and $\mathbf{2 5}$ who give evidence of fair moral character are eligible. State cadets who remain in the institute 2 years or more are obligated to teach in some school in the State after leaving the institute, or, in lieu of such service, to serve an enlistment in the National Guard of the State, or as an engineer in the State Highway Commission.

Virginia Polytechnic Institute, Blacksburg.-Free tuition may be allowed applicants whose homes are in Virginia, for a period of 2 years. The law provides that on recommendation of the faculty of the college, for more than ordinary diligence and proficiency, any student so selected may be continued for a longer period. A student who carries a full schedule and passes all of his classes satisfactorily and whose quality credits are up to the standard required for graduation, will have this privilege renewed as long as his record remains satisfactory as indicated.

Virginia State College (Negro), Ettrick.-A number of students, men and women, equal to twice the number of members of the house of delegates and apportioned in the same manner, are given free tuition at the college. Selections are made by division superintendents of schools for the respective counties and cities. Candidates must give evidence of good scholarship and good moral character.

WEST VIRGINIA

State aid to students taking advanced courses outside the State.-All bonafide residents of West Virginia who have been residents of the State for 5 years, and who have completed the equivalent of 2 years of college work preparatory to special courses to be pursued outside of the State, and those who are pursuing or may pursue courses in institutions outside the State the same as those taught in West Virginia University or other West Virginia schools but because of certain provisions in the constitution of West Virginia cannot pursue such 
courses in West Virginia University or other State school, and no similar courses being taught in the State schools provided for them, may have their annual tuition and fees paid by the State, to the amount paid by a nonresident student of the State university or other State-supported school, over and above the amount of tuition and fees paid by a resident student of the State university or other schools. The State board of education and the Negro board of education, Charleston, W. Va., jointly administer the fund.

\section{WISCONSIN}

University of Wisconsin, Madison.-Legislative scholarships. For nonresident students. Remission of tuition ( $\$ 200$ a year) to a number of needy and worthy students from other States, upon the basis of merit. Total number about 235. Available for undergraduate and graduate students.

\section{FOR WORLD WAR ORPHANS}

Alabama.-Orphans of the World War who are not under 16 and not over 21 years of age and who have been domiciled in the State for 12 months, may attend State educational or training institutions of secondary or college grade free from the payment of tuition, and may have their expenses paid for matriculation, board, room rent, books, and supplies, to an amount not to exceed $\$ 150$ a year. The State board of education, Montgomery, is charged with the administration of the scholarships.

Arizona.-The Veterans' Relief Commission, Phoenix, is authorized to provide from its annual appropriations such assistance as it may deem necessary in the education of war orphans of Arizona. The amount of aid for each child and the requirements for eligibility are fixed by the commission.

Arkansas.-War orphans not under 16 and not over 22 years of age who have resided in the State for 12 months, may attend State educational institutions of secondary or college grade free from the payment of tuition. An annual appropriation is made to provide funds for the payment of matriculation fees, board, room rent, books, and supplies for such children. The amount for each child is not specified. The State board of education, Little Rock, supervises the payments.

California.-War orphans who are not less than 16 nor more than 21 years of age and who have lived in California for 5 years, may apply to the Veterans' Welfare Board, Sacramento, for assistance to enable them to continue their education. The board may provide educational counsel for the applicants and when necessary assist them in securing admission to suitable institutions of learning. Private tuition schools may be chosen only when suitable opportunity is not available in public or semipublic institutions. The board has the power to provide for the payment of tuition and other fees, for the purchase of books and supplies, and for living expenses. The amount expended for any one student of college, business, and trade-school rank may not exceed $\$ 25$ a month, or $\$ 250$ a year; for students of secondary rank it may not exceed $\$ 15$ a month, or $\$ 135$ a year. Should the funds available be insufficient to supply the needs of all applicants, the board will assume wardship over such as are most urgently in need of further education.

Connecticut.-War orphans not under 16 and not over 23 years of age, whose fathers entered the service of the United States from Connecticut, or, subject to the same restrictions as to age, orphans of veterans who have resided in Connecticut for 5 years continuously, may attend any State educational or training institution of college grade, a State normal school, trade school, or commercial training school within the State, free from the payment of fees for tuition, matriculation, board, room rent, books, and supplies, provided 
such fees do not exceed $\$ 200$ a year. The State board of education, Hartford, is charged with administration of the scholarships.

Delaware.-War orphans and post-war orphans not under 16 and not over 21 years of age, may have their expenses paid for tuition, matriculation, board, room rent, books, and supplies, at any educational or training institution in the State, provided the amount paid for such expenses does not exceed $\$ 200$ a year for each child. Residence in the State for 12 months prior to making application is required. A child who is pursuing a 4-year course of study and arrives at the age of 21 while taking such course, may receive the benefits of this provision until the course is completed. The director of the State board of vocational education, Newark, Del., administers the funds.

District of Columbia.-An act of Congress, approved June 19, 1934, provides $\$ 200$ a year for each war orphan between the ages of 16 and 21 , who has had his domicile in the District of Columbia for at least 5 years "for aid in the education" of such war orphan, "including tuition fees, maintenance, and the purchase of books and supplies." The board of education of the District of Columbia is charged with the administration of the act.

Florida.-War orphans between the ages of 16 and 22, either of whose parents entered the military, naval, marine, or nurse corps services of the United States from Florida, or war orphans who have been bona fide residents of Florida for 5 years, may attend State educational or training institutions of secondary or college grade free from the payment of tuition, and have their expenses paid for matriculation, board, room rent, and books, to an amount not to exceed $\$ 300$ a year of 12 months. These benefits may not be received for more than 4 years. The State board of control, Tallahassee, administers the fund.

Georgia.-War orphans not under 16 and not over 21 years of age who have had their domicile in the State for $\mathbf{1 2}$ months, and are attending or may attend an educational or training institution of a secondary or college grade located within the State, may have their expenses paid for matriculation fees, board, room rent, books, and supplies, to an amount not to exceed $\$ 150$ a year. They may also be admitted to State institutions of secondary or college grade free of tuition. The Director of the Veterans' Service Office, Atlanta, administers the fund.

Idaho.- The Veterans' Welfare Commission, Boise, is authorized to provide from its annual appropriation such assistance as it may deem necessary in the education of Idaho war orphans. The amount that each child may receive and the requirements for eligibility are fixed by the commission.

Illinois.-War orphans not under 16 and not over 22 years of age who have been domiciled in the State for 12 months, may attend State institutions of secondary or college grade free from the payment of tuition, and from the payment of fees for matriculation, board and room, books and supplies, to an amount not to exceed $\$ 150$ a year. The Department of Registration and Education, Springfield, administers the fund.

Indiana.-Pupils of the Soldiers' and Sailors' Children's Home, and children not under 16 and not over 21 years of age, who for 12 months preeeding their application have had their domicile in the State of Indiana, and whose fathers were killed in action or died from other causes while serving in the armed forces of the United States, may attend the State higher educational institutions, including Indiana University, Purdue University, Ball State Teachers College, and Indiana State Teachers College, without payment of tuition or matriculation fees.

Iowa.-War orphans not under 16 and not over 21 years of age, who have lived in the State of Iowa for 2 years, may have their expenses for tuition, matricu- 
lation, laboratory and similar fees, books, and supplies paid, to an amount not to exceed $\$ 150$ a year for each child, for attendance at any educational or training institution of college grade located within the State of Iowa. The Iowa Bonus Board, Des Moines, is charged with administration of the fund.

Kentucky. - Scholarships for World War orphans entitle the holders to attendance at any State educational institution of secondary or college grade free from the payment of tuition, and from the payment of matriculation fees, board, room rent, books, and supplies, to an amount not to exceed $\$ 150$ a year. Beneficiaries may not be under 16 nor more than 22 years of age, and must have resided in the State for 12 months. If any of the scholarships are not used for children attending colleges and secondary schools, they may be given to eligible war orphans who desire to enroll in vocational, technical, or business schools, provided that not more than 6 scholarships be so awarded in any one year. The State board of education, Frankfort, is charged with administration of the scholarships.

Louisiana.-Amendments to the Female Student, Beneficiary Cadet, and Agricultural Student acts (see p. - $\rightarrow$ ) give preference in the selection of the beneficiaries to war orphans. Beneficiaries of the Female Student Act may have their expenses paid at State-supported higher institutions to an amount not to exceed $\$ 250$ a year, and of the Beneficiary Cadet Act $\$ 350$ a year. Beneficiaries of the Agricultural Student Act are not limited in the amount of their expenses.

Maine.-War orphans not under 16 and not over 22 years of age whose fathers entered the service of the United States from Maine, or who themselves have been resident of the State for 5 years may enter the State institutions of collegiate grade free from the payment of tuition, and from charges for matriculation, board, room rent, books, and supplies, to an amount not to exceed $\$ 150$ a year. The State department of education, Augusta, is charged with administration of the fund.

Maryland.-The Maryland Veterans Commission, Baltimore, is authorized, in its discretion, to expend from funds under its control, not to exceed $\$ 150$ annually for each war orphan of Maryland who has reached the age of 18 , to enable him to attend a secondary school, college, or university, or pursue a course of vocational training. War orphans are defined as children of persons who served in active duty in time of war, campaign, or expedition, in the Army, Navy, or Marine Corps of the United States and who received an honorable discharge from such service.

Massachusetts.-War orphans resident in Massachusetts, not under 16 and not over 22 years of age, whose fathers entered the service from Massachusetts, are entitled to reimbursement by the State, in an amount not to exceed $\$ 250$ in any year, for expenses incurred for tuition, board, room rent, transportation, books, and supplies necessary or incidental to pursuit of study at any State or county educational institution, and for expenses for the above-named items, except tuition, in any other educational institution approved by the commissioner of education. The benefits of this provision may not be enjoyed for a longer period than 4 years. The State commission of education, Boston, is charged with administration of the fund.

Michigan.-War orphans not under 16 and not over 22 years of age who have resided in the State for 12 months, may attend any State educational or training institution of a secondary or college grade without payment of matriculation fee, athletic fee, or tuition, during the time in which he is a student at the institution. The State board of education, Lansing, administers the fund.

Minnesota.-War orphans, not under 16 and not over 22 years of age who have had their domicile in Minnesota for 2 years, may have their expenses paid for 
matriculation, board, room rent, books, and supplies, to an amount not to exceed $\$ 200$ a year, at "any educational or training institution of a secondary or college grade located within the State of Minnesota and approved by the State board of education." They may be admitted to the State-supported institutions of secondary or college grade free of tuition. The State soldiers' welfare director, St. Paul, is charged with administration of the fund.

Montana.-War orphans between the ages of 16 and 21 whose fathers had legal residence in Montana at the time they were "commissioned, warranted, enlisted, or inducted into the military or naval service of the United States", may attend State institutions of learning free from the payment of tuition, matriculation fees, board, room rent, books, and supplies to an amount not to exceed $\$ 250$ a year. The State board of education, Helena, administers the fund.

Now Hampshire.-War orphans between the ages of 16 and 21, whose fathers were enlisted or inducted into service from New Hampshire, may be admitted to State institutions of secondary or college grade free from the payment of tuition and from charges for board, room rent, books, and supplies to an amount not to exceed $\$ 150$ a year. The beneficiaries must be children who without this aid would be unable to attend such institutions. The State board of education, Concord, administers the fund.

New Jersey.-War orphans between the ages of 16 and 21 years of age, "domiciled in this State at the time of application for the benefits of this act first having been made and for a period of at least 12 months prior to its enactment" (Mar. 31, 1930; amended 1933), may have their expenses paid for tuition, matriculation, board, room rent, books, and supplies "at any State educational or other technical or professional school of a secondary or college grade in this State", to an amount not to exceed $\$ 150$ a year. It is provided "that when the application of any such war orphan shall have been granted in the first instance as herein provided, then the maximum number of annual allotments herein provided may be granted to such applicant for and during consecutive years regardless of the fact that such applicant shall be above the age of 21 years at the time of the granting of any such annual allotment subsequent to the first." The adjutant general of the State, Trenton, is charged with administration of the fund.

New Mexico.-War orphans, not under 16 and not over 22 years of age, of those who enlisted from the State of New Mexico, may be admitted to State institutions of secondary or college grade free from the payment of tuition, and from charges for matriculation, board, room rent, books, and supplies to an amount not to exceed $\$ 150$ a year. The State board of education, Santa Fe, is charged with administration of the fund.

New York.-War orphans of resident soldiers, sailors, marines, and trained nurses who died while serving in the armed forces of the United States, or as a result thereof, may receive scholarships which entitle them to free tuition not to exceed $\$ 100$ a year for 4 years, in any university, college, normal, technical; or trade school of his selection located within the State, together with $\$ 100$ additional a year for maintenance. The award of the scholarships is made by the State commissioner of education, Albany.

North Dakota.-War orphans, not under 16 and not over 21 years of age, may attend any State educational or training institution of secondary or college grade free from the payment of tuition and other fees. This privilege is limited to the 35 war orphans now domiciled in the State, such orphans having been born between the years 1912 and 1921, both inclusive. The State board of administration, Bismarck, is authorized to waive payment of the fees. 
Oklahoma.-The soldiers' relief commission, Oklahoma City, is authorized to set aside from its annual appropriation a sufficient amount to pay for the expenses of any worthy and needy war orphan desiring higher education.

Pennsylvania.- -War orphans, between the ages of 16 and 21 years of age, who have lived in Pennsylvania for 5 years and are attending any State or Stateaided educational or training institution of a secondary or college grade, may have their expenses paid for matriculation, tuition, board, room rent, books, and supplies to an amount not to exceed $\$ 200$ a year. "Where a child within the class described is completing an educational or training course and before completing the course the child arrives at the age of 21 years it shall be lawful for the gratuity to be paid until the course is completed." The State veterans' commission, Harrisburg, is charged with administration of the fund.

Rhode Island.-War orphans, not under 16 and not over 21 years of age, whose fathers had legal residence in Rhode Island at the time of their enlistment or induction into service, may attend the Rhode Island State College, the Rhode Island College of Education, or any other institution of learning in Rhode Island, and have their expenses for tuition, matriculation, board, room rent, books, and supplies paid for, in whole or in part by the State, for a period not to exceed 4 years. The State board of education, Providence, administers the fund.

South Carolina.-War orphans, whose fathers entered the service of the United States from South Carolina, may be admitted, upon the recommendation of the State board of education, to any State-supported college or university free of tuition and have their expenses paid for board, room rent, books, and supplies to an amount not to exceed $\$ 150$ a year. The State board of education, Columbia, administers the fund.

Tennessee.-War orphans, not under 16 and not over 22 years of age, who for 12 months have had their domicile in the State, may be admitted to State institutions of college or secondary grade free from the payment of tuition, and from the payment of fees for matriculation, board, room, books, and supplies to an amount not to exceed $\$ 150$ a year. The State board of education, Nashville, administers the fund.

Utah.-War orphans, not under 16 and not over 21 years of age, who have for 12 months had their domicile in the State, may attend State educational or training institutions of a secondary or college grade free of expense for tuition, matriculation, board, room rent, books, and supplies to an amount not to exceed $\$ 150$ a year. The State superintendent of public instruction, Salt Lake City, administers the fund.

Vermont.-Needy war orphans, not under 16 and not over 21 years of age, who have had their domicile in Vermont for 12 months, may attend an educational or training institution of secondary or college grade within the State and have their expenses paid for matriculation, tuition, board, room rent, books, and supplies, to an amount not to exceed $\$ 150$ a year. Such children may be admitted to State institutions of secondary or college grade free of tuition. The State board of education, Montpelier, administers the fund.

Virginia.-War orphans, not under 16 and not over 21 years of age, of those who enlisted in the service from Virginia, may have their expenses paid for matriculation, board, room rent, books, and supplies to an amount not to exceed $\$ 150$ a year at any educational institution in the State approved in writing by the State superintendent of public instruction. Children of those who did not enter the service from the State of Virginia must have resided in the State for at least 5 years prior to the date on which the act became effective (Mar. 24, 1930; amended, Mar. 18, 1932). Upon recommendation of the State board of education, all such children may be admitted to State institu- 
tions of secondary or college grade free of tuition. The State board of education, Richmond, administers the fund.

West Virginia.-War orphans, not under 16 and not over 22 years of age, who have had their domicile in the State for 12 months, may attend State educational and training institutions free from the payment of tuition, and from expense for matriculation fees, board, room rent, books, and supplies and other necessary living costs to an amount not to exceed $\$ 150$ a year. In selecting those to receive these benefits, preference is given to needy students and to those whose parents were domiciled in the State during the period of their war service. The department of public welfare is charged with administration of the fund.

Wisconsin.-Children of World War veterans, not under 16 and not over 24 years of age, who desire to continue their education in any public, elementary, high, or vocational school of the State, or in special schools organized for this purpose, or in the county training or county agricultural schools, the mining school, normal schools, Stout Institute, or in the University of Wisconsin, or in any other institution of learning in the State at which there was organized a Student Army Training Corps unit, or in any other institution of learning of high-school or college grade in the State not run for profit, are entitled to receive $\$ 30$ a month while in regular attendance at any such institution, or a total not to exceed $\$ 1,080$. (The acceptance of the soldier bonus, provided for in the Wisconsin laws of 1919 , precludes the granting of this aid to a veteran's children unless the veteran returns to the State treasury the amount of the bonus received.) The adjutant general of the State is charged with administration of the fund.

\section{FOR WORLD WAR VETERANS}

Arkansas.-All honorably discharged veterans of the World War, who were citizens of the State of Arkansas at the outbreak of the war and who are otherwise properly qualified, may be admitted to any school or university supported by State funds without the payment of tuition or matriculation fees; provided that this shall not apply to those veterans who received training under contract with the Federal Government.

minois.-World War veterans, who served in the Army, Navy, or Marine Corps of the United States and who at the time of entering the service were residents of Illinois, are entitled to scholarships at the University of Illinois which cover incidental and matriculation charges ( $\$ 70$ to $\$ 152.50$, depending upon the college in which the student enrolls). Candidates must possess all necessary entrance requirements for the college or curriculum which he proposes to enter.

Iowa.-All honorably discharged soldiers and sailors of the World War, who are citizens of Iowa, are exempt from the payment of fees amounting to $\$ 40$ annually at the Iowa State institutions of higher learning.

Kentucky.-Persons who served in any branch of the military and naval services of the United States during the World War, who at the time of enlistment were residents of Kentucky, are entitled to free scholarships at any of the State higher educational institutions of Kentucky. The scholarships cover tuition, matriculation and other fees, room rent, fuel, and light (but not board), and transportation to and from the institutions once each way during the year for those who continue their studies for a consecutive school year of 10 months, and are tenable for the period necessary for the completion of the course of study chosen by the applicant.

Montana.- Upon the proper certification of the president of one of the units of The University of Montana that a student has rendered military or naval 
service to the United States during the time of the Nation's actual participation in war and has been honorably discharged, the chancellor of the University of Montana (who is the chief executive officer of the combined institutions of higher learning in Montana) will authorize the award to such student of a military-service scholarship exempting him from the payment of all regular fees, exclusive of laboratory deposits and special course tuitions throughout his college course.

New York.-Soldiers, sailors, marines, and trained nurses, residents of New York, who served in the World War and have been honorably discharged from the service, may receive scholarships which entitle them to free tuition not to exceed $\$ 100$ a year for 4 years, in any university, college, normal, technical, or trade school of his selection located within the State, together with $\$ 100$ additional a year for maintenance. Award of scholarships is made by the State commissioner of education, Albany.

Ohio.-Citizens of Ohio, who have resided within the State for 1 year and who were in the active service of the United States as soldiers, sailors, nurses, or marines between April 6, 1917, and November 11, 1918, and who were honorably discharged from such service, may be admitted to any school, college, or university which receives State funds toward its support, without being required to pay tuition or matriculation fees.

Oregon.- -Honorably discharged soldiers, sailors, or marines, or soldiers, sailors, or marines in reserve, who were in the service of the Army, Navy, or Marine Corps of the United States during the World War and who were enlisted or inducted into service from Oregon prior to November 11, 1918, and who desire to attend either public or private institutions of learning in the State, may be granted financial assistance by the State to an amount not to exceed $\$ 25$ for any 1 month, and not to exceed $\$ 200$ for any 1 year, for a period of not to exceed 4 years.

South Dakota.-Residents of the State, who have rendered active war service in the Army or Navy of the United States and who have been discharged from such service, are entitled to free tuition at any of the State educational institutions under the control of the regents of education of South Dakota. This includes persons who have performed active war service in nursing or assisting in the care of soldiers or sailors as members of recognized war-relief organizations, such as the Red Cross. The University of South Dakota, the South Dakota State College of Agriculture and Mechanic Arts, the South Dakota State School of Mines, the Northern Normal and Industrial School, the Eastern State Normal School, the Southern State Normal School, and the State Normal School at Spearfish come under the provisions of the statute.

Texas.-Citizens of Texas, who have resided in the State for not less than 12 months and who served as nurses or as members of the armed forces of the United States during the Spanish-American or World War and were honorably discharged therefrom, are exempt from the payment of all fees, dues, and charges (including fees for correspondence courses) for attendance at the State-supported institutions of collegiate rank. These exemptions do not cover lodging, board, and clothing.

Wisconsin.-Any person discharged, released, or furloughed subsequent to April 7,1917 , upon honorable conditions, from any branch of the military or naval services of the United States, including all Red Cross and other nurses in military camps or hospitals who were a part of the military or naval forces of the United States in this country or overseas during the World War, and who at the time of entering the service, which must have been prior to November 12, 1918, was a resident of Wisconsin, and was in the service at least 3 months, who desires to continue his education in any public, elementary, high, 
or vocational school of the State, or in special schools organized for this purpose, or in the county training or county agricultural schools, the mining school, normal schools, Stout Institute, or in the University of Wisconsin, or in any other institution of learning in the State at which there was organized a Student Army Training Corps unit, or in any other institution of learning of high-school or college grade in the State not run for profit, is entitled to receive $\$ 30$ a month while in attendance as a student at any such institution, or a total not to exceed $\$ 1,080$. (The acceptance of the soldier bonus provided for in the Wisconsin laws of 1919 precludes the granting of this aid to a veteran, unless he returns to the State treasury the amount of the bonus received.) The adjutant general of the State administers the fund.

NoтE.-Attention is also called to the scholarships for war veterans offered at the Colorado School of Mines (see p. 28) and at the University of Michigan (see p. 31); and to the scholarships for veterans and their children offered by the estate of La Verne Noyes (see p. 3).

\section{SCHOLARSHIPS AND FELLOWSHIPS AUTHORIZED BY INSTITUTIONAL BOARDS OF TRUSTEES}

In addition to the scholarships made possible by direct State appropriations, many State colleges and universities provide scholarship aid for their students out of the funds allotted to them for their own support. As a rule, this aid is given for the definite purpose of helping students of superior ability, and a high grade of performance must be maintained in order to secure and hold the scholarships. Help of this kind is given by State institutions to both undergraduate and graduate students. Usually the undergraduate scholarships are available to State residents only, but in some institutions they are specially designated for students from other States. Furthermore, many institutions also provide a number of assistantships, which require usually only a small amount of service and are available as a rule to students engaged in advanced study or research work. These carry, of course, much larger amounts of money than do scholarships and fellowships, the average annual amount being around $\$ 500$.

In the following paragraphs are given briefly the main facts concerning scholarships, fellowships, and assistantships offered by individual State-supported colleges and universities. It is probable that other institutions than those listed offer assistantships to graduate students but failed to report this form of student aid.

\section{UNDERgRadUATE Scholarships}

ARKANSAS

University of Arkansas.-University scholarships: One annually to each class A and class B high school. Awarded to honor graduate or, as second choice, to the graduate of that year who has made the highest record during his or her entire course. Cover cost of matriculation, registration, and library fees, $\$ 30$ for 1 year.

\section{CALIFORNIA}

University of California.-State of California scholarships: Distributed among the 20 congressional districts of the State. Awarded to poor and deserving students. Annual value, $\$ 125$.

$75014^{\circ}-36-3$ 


\section{COLORADO}

Colorado State institutions of higher education.-(1) High-school honor scholarships: Available at the six State institutions of higher education. Granted to graduates of accredited high schools; 1 for each 25 graduates, or any part thereof up to 5 , the maximum granted to any high school. Award based on scholarship standing. Recipients must have had 2 full years of work in the senior high schools from which they graduate. Annual value covers tuition or fees. Tenure, 4 years.

(2) In addition to the high-school honor scholarships, each of the six State institutions may remit tuition or fees of exceptionally worthy students who do not qualify under the high-school scholarship plan. Such students must be recommended by a committee of the high-school faculty and passed upon by a committee composed of the registrar and two faculty members appointed by the different presidents. Total number of students who may receive this benefit at any of the institutions, 25 .

Colorado School of Mines.-(1) United States scholarships: One scholarship may be awarded each year to each State in the Union and to territorial and insular possessions of the United States on the recommendation of the superintendent of public instruction. The scholarship may be held 4 years or any part thereof, but may not extend beyond graduation. Annual value, approximately $\$ 250$, in fees.

(2) Foreign scholarships: One scholarship may be awarded each year to foreign countries or governments upon the recommendation of the minister of education. Annual value, approximately $\$ 250$ in tuition and fees.

(3) United States Army and Navy scholarships: Awarded to men who were in the service during the World War and who have been honorably discharged.

$\Delta$ dams State Teachers College.-Board of trustees scholarships: Four, given to sophomores at the end of the second year.

Colorado State College of Education.-(1) Board of trustees scholarships: Four given annually; two to men and two to women having the highest scholastic standing in the sophomore class. The scholarships cover the regular college fees for the remaining 2 years of college.

(2) State superintendent of public-instruction scholarships: Awarded to the man and woman in the senior class having the highest scholarship standing. Cover the regular college fees for 1 year of graduate work.

Western State College of Colorado.-(1) State superintendent of public-instruction scholarships. Awarded to the senior highest in scholarship rank. The recipient must have earned 180 hours at Western State College.

(2) Board of trustees scholarships: Awarded to the sophomore man and the sophomore woman highest in scholarship, who have earned not less than $\mathbf{8 0}$ nor more than 110 credits at Western State college.

\section{ILLINOIS}

University of mlinois.-(1) Scholarships in agriculture and home economics: Two for each county (except Cook and Lake) and 2 for each of the first 10 congressional districts, 1 for students in agriculture, and 1 for students in home economics. An applicant must have been a resident of the county for at least 1 year; must rank in the upper half of his high-school graduating class, or, if he has completed 1 year or more of college work must have an average 15 points above passing; must be recommended by the Illinois Farmers' Institute; must pass a competitive examination; must qualify for admission to the university as a regular or unclassified student in agriculture or home economics. The person receiving the highest average in the competitive examination is awarded the scholarship. No person who has attended the university is eligible. Schol- 
arship exempts holder from the payment of matriculation and incidental fees. Tenure, 4 years.

(2) Scholarships in ceramics: One for each county in the State. Candidates must be residents of counties from which nominated and must meet in full university admission requirements. No student who has attended the university is eligible. Scholarships cover matriculation and incidental fees. Tenure, 4 years, provided the student continues in the ceramics curriculum. Nominations made by Illinois Clay Manufacturers' Association, Urbana, Ill.

(3) Summer session scholarships: All high-school teachers in Illinois, and all teachers in the State who can matriculate in the university, are entitled to summer session scholarships of $\$ 12$. Similar scholarships are granted to librarians and assistants employed by Illinois libraries and persons under appointment to such positions or under contract to teach in the State during the coming year.

\section{INDIANA}

Indiana University.-(1) Various scholarships for extension work are offered through the centers at Indianapolis, Fort Wayne, East Chicago, South Bend, and Logansport.

(2) The university may grant to two members of the entering law-school class each year a scholarship consisting of a remission of contingent fees for the year. In granting these scholraships consideration is given to the quality of the college record presented, the financial need, and the personality of the applicant. Preference will be given to applicants entering with 4 years of college credit and to residents of the State. The scholarships may be renewed for the second and third year if the law-school record of the student warrants it.

(3) School of music scholarships: Four, covering a semester's fee valued at $\$ 90$. Awarded to the winners of highest place in the piano, violin, voice, and cello divisions of the State High School Music Contest held at the university each spring under the auspices of the school of music and extension division.

Purdue University.-(1) 4-H club scholarships: Winners in boys' and girls' club classes. Exemption from fees amounting to $\$ 60$ a year.

(2) Vocational rehabilitation service: Young persons who have been injured by accident or otherwise and who have not the means of financing college training. Approved persons receive compensation for fees and books for the period during which they remain enrolled.

(3) Military scholarships: Citizens military training camps at Fort Benjamin Harrison, Fort Thomas, and Camp Know are granted one scholarship each. Value, $\$ 30$ a semester.

(4) Undergraduate students enrolled for degrees who carry at least 14 semester-hours of work and make a scholarship index of 5 or more at the end of any semester are entitled to receive remission of fees to the extent of $\$ 30$ for the semester immediately following.

(5) Special merit scholarships: Awarded to outstanding graduates of high schools. Annual value, exemption from fees to the extent of $\$ 30$ a semester; to students from outside Indiana exemption from the out-of-State fee also. Applicants for these scholarships must pass certain examinations with high grades. They must maintain high averages in order to retain them.

\section{IOWA}

Iowa State College of Agriculture and Mechanic Arts.-Fee exemptions are granted to a limited number of students who make proper showing of merit and need: Residents of Iowa are granted exemption of $\$ 60$ a year; residents of other States, $\$ 40$ a year; foreign students, $\$ 60$ a year. 
State University of Iowa.-(1) Fee exemptions are granted to a limited number of meritorious and needy students who are residents of Iowa, in the colleges of liberal arts, engineering, education, and commerce: They will be continued upon maintenance of an average of 1.75. Exemption granted, $\$ 60$ a year.

(2) A limited number of fee exemptions to the amount of $\$ 10$ for each term of the summer session are available on the same basis as above to seniors who expect to graduate at the end of the summer session and who have been previous recipients of this scholarship.

(3) Public-speaking scholarships: Any approved high school in the State is eligible to membership in the Iowa High School Debating and Extemporaneous Speaking League. To each of the finalists, six debaters and two speakers, who annually compete for the league chamiponship, the university offers a 4-years' scholarship which exempts the holder from the payment of $\$ 30$ of the regular semester fee during each of the 4 years of his college course unless it is forfeited because of low scholarship.

(4) Music exemptions: A limited number of applied music fee exemptions will be granted annually to talented students who require aid. Applicable only to students in applied music who hold no other form of tuition exemption.

(5) In addition to the above scholarships and exemptions, the board of education provides a limited number of fee exemptions for needy and worthy students.

\section{LOUISIANA}

Louisiana State University.-(1) High-school honor scholarships: Offered to the honor graduate of each approved high school in Louisiana. Selection of the recipient rests with the faculty of each school.

(2) High-school rally scholarships: Students who win first place in the various contests at the State high-school rally held at the university are awarded a university scholarship.

(3) Scholarships established by the board of supervisors: Awarded by the Governor of the State, the president of the university, and by each member of the board.

All of the foregoing scholarships exempt students from the payment of fees for matriculation, hospital, library, and stated laboratory fees. They are valid for 4 years, unless forfeited by reason of unsatisfactory school work.

(4) Out-of-State scholarships: Awarded to the honor graduate of each approved high school in neighboring States. Exempt holder from payment of tuition fee, $\$ 60$ a session, or $\$ 240$ for the 4 years during which they may be held. Not valid in the school of medicine.

(5) Self-help scholarships: The Louisiana State University has established a number of scholarships by means of which students may pay a part of their expenses by work that need not interfere with their studies. These scholarships are given usually to upperclass students who have made good scholastio records or who have special qualifications for the work to be done.

\section{MAINE}

University of Maine.-(1) Trustee undergraduate scholarships: Five, annual value, 1 year's tuition. Awarded primarily on the basis of scholarship standing.

(2) Secondary school contest scholarships: Eight, annual value, 1 year's tuition. Awarded each year on the basis of competitive examinations to freshmen entering the university from Maine secondary schools.

(3) Trustee scholarships: Fifteen, annual value, 1 year's tuition. Granted to students of high scholastic standing, good character, and intellectual promise, who are in need of financial assistance. Awards made by the faculty committee on honors, with the approval of the president. 
(4) Trustee scholarships for normal schools: Three, for use in the junior year of the school of education. Awarded to graduates of the 2-year training course in the several State normal schools.

\section{MICHIGAN}

Michigan College of Mining and Technology.-(1) Michigan State scholarships. A scholarship each year to a deserving student from every high-school graduating class in the State. Exempts such students from matriculation and general term fees, provided their scholarship, attitude, and conduct are satisfactory to the faculty. They are, however, required to make the usual $\$ 25$ deposit, which is returned to them when they withdraw from the institution, and to pay annually the student organization fee of $\$ 10$, a clubhouse maintenance fee of $\$ 1.50$, and the medical examination fee of $\$ 1.50$.

University of Michigan.-(1) United States Army veteran scholarships: Five, limited to honorably discharged veterans of the United States Army in the World War or of the United States Regular Army, who must be recommended by the Adjutant General of the Army. Cover semester fees.

(2) American Indian scholarships: Five, assigned to American Indian students, who must be recommended by the Secretary of the Interior or his representative. Cover semester fees.

(3) University scholarships in professional schools: Three each given annually in the medical school and law school; two each in the schools of dentistry and of education; and one each in the schools of business administration and of forestry and conservation. Only regularly enrolled seniors in these schools are eligible.

\section{MISSOURI}

Lincoln University (Negro), Jefferson City.-A scholarship to the ranking graduate of any accredited high school in Missouri, provided the applicant matriculates in Lincoln University the next semester immediately following his or her graduation from high school: Value, $\$ 25$ a semester. Beneficiary must maintain a creditable record during the first semester in order to be entitled to a continuance of the scholarship during the second semester.

\section{MONTANA}

University of Montana (includes the five State institutions of higher education).-(1) High-school honor scholarships: Open to graduates of accredited high schools. Available for use at any State higher educational institution in Montana. Nominations made by principals of accredited high schools of from one to four graduates, depending upon size of class (but not more than two for any one higher institution). Scholarships exempt holders from payment during the freshman year of all customary fees except the student activity fees and the special fees in the schools of law and music.

The five units of the University of Montana are:

State University of Montana, Missoula.

Montana State College, Bozeman.

Montana School of Mines, Butte.

Montana State Normal College, Dillon.

Eastern Montana Normal School, Billings.

(2) Advanced scholarships: Each unit of the University of Montana is authorized by the State board of education to award to 5 percent of the students in regular attendance above the freshman year, scholarships exempting the holders from payment of the registration and incidental fees. Awards are made on the basis of ability, character, and promise. 
Montana School of Mines.-Scholarships for foreign students: One offered each year to a high-school honor graduate in each foreign country, to be bestowed by the American consul. The person nominated should have sufficient command of English to be able to follow the course of instruction successfully, and his preparation should be equivalent to that of a good 4-year American high school. He should be of the type who is likely to succeed both as a technical student and as an engineer after graduation.

\section{NEBRASKA}

University of Nebraska.-Regents' scholarships: Two hundred and fifty, open to graduates of Nebraska high schools in the upper quarter of the graduating class. Granted annually, on basis of competitive examinations. Exempt holders from payment of general fees, approximately $\$ 35$ a semester, during the freshman year.

Nebraska State Teachers Colleges.-Scholarships for honor graduates of accredited high schools: May be presented at any of the four State teachers colleges. Applicants must hold rank in the highest 10 percent of the graduating classes. Holders are entitled to free tuition and fees amounting to $\$ 37.50$ a year, for 4 years. Open to men and women.

The Nebraska State teachers colleges are located at Chadron, Kearney, Peru, and Wayne.

\section{NEVADA}

University of Nevada.-(1) Regents' scholarships: Five, awarded annually to regular students on the basis of scholarship, one to a freshman, two to sophomores, and two to juniors. Value, $\$ 50$.

(2) The regents have exempted the following Federal groups from payment of the nonresident tuition charge: (a) Officers and enlisted men in active service of the United States Army and Navy and their children; (b) sons and daughters of officers, warrant officers, and enlisted men in active service in the Coast Guard.

(3) A total of not more than 10 students in any one university year will be admitted without the payment of the nonresident tuition fee from Mexico, Central America, and South America; provided that not to exceed three such students from any one nation in this area receive this exemption within the same year. Such students are required to pay all other regular university charges.

\section{NEW HAMPSHIRE}

University of New Hampshire.-Two hundred and fifty scholarships, awarded to New Hampshire students who need and deserve financial assistance: Annual value, $\$ 75$. Tenure, 1 year. Given to students who have attended the university less than 3 terms.

\section{NORTH CAROLINA}

University of North Carolina.-Free tuition is given in the college and in the nonprofessional schools to residents of North Carolina under bodily infirmity, subject to approval of the State department of vocational rehabilitation.

\section{OHIO}

Ohio State University.-(1) State-wide scholarship contest awards: Thirtythree-one 4-year, two 3-year, six 2-year, and twenty-four 1-year. Cover tuition for the number of years designated.

(2) Scholarships in the college of agriculture: Twenty given annually. Awarded to the members of the graduating classes of first-and second-grade high schools, through a competitive examination in high-school agriculture. Annual value, $\$ 60$. 


\section{PENNSYLVANIA}

By resolution of the Pennsylvania State Senate "each college, university, or other institution of learning, receiving appropriations from the Commonwealth, shall for such appropriation period, award to each member of the senate of the general assembly of the Commonwealth, three scholarships in a complete course of study at said college, university, or institution."

The institutions which receive appropriations from the State of Pennsylvania and at which provision for the award of "senatorial" scholarships is made are: Pennsylvania State College, State College; Hahnemann Medical College, Philadelphia; Jefferson Medical College, Philddelphia; Temple University, Philadelphia; University of Pennsylvania, Philadelphia; University of Pittsburgh, Pittsburgh; Womans Medical College of Pennsylvania, Philadelphia.

\section{VERMONT}

University of Vermont.-(1) Honor scholarships: Awarded annually by the board of trustees to the young man and the young woman graduating with highest standing from a college-preparatory course in each of the Vermont high schools accredited by the State board of education. Value, \$200. Tenure, 1 year.

(2) Interscholastic debating scholarships: The final contest of the Interscholastic Debating League is held at the university. Each member of the team winning the decision in this contest is awarded a scholarship covering full tuition of $\$ 300$. Members of the losing team receive half scholarships.

(3) High-school editorial scholarships: Four, offered to members of the editorial boards of Vermont high-school publications. Values, $\$ 175, \$ 150$, and $\$ 125$, according to the size of the high school, and $\$ 100$ irrespective of size of high school, but awarded to the editor of the publication showing the most improvement over the previous year. The scholarship in each case goes to the editor-in-chief of the winning publication, or, in case the editor is not an applicant, it may be given to the business manager or to some other senior member of the staff.

(4) Prize speaking contest scholarships: Six, one of $\$ 150$ and one of $\$ 100$, offered to the ranking winners in each of the three districts of the Vermont State Interscholastic Prize Speaking Contest. Three scholarships of $\$ 150$, $\$ 100$, and $\$ 75$ are also awarded to the first, second, and third ranking participants in the final contest.

(5) Vocal music contest scholarships: Eighteen, given annually to students of the secondary schools of Vermont who win awards in district and final vocal music contests. These contests are held in three districts under the auspices of the department of music and the supervision of the Vermont Headmasters' Club. The first prize for boys and the first prize for girls in each district is a $\$ 150$ scholarship. The district second prizes are $\$ 100$ each. The winners of the district contests participate in a final competition at the university for three scholarships for men and three for women. The values of the awards for the final contest are $\$ 150, \$ 100$, and $\$ 75$.

(6) Literary scholarships: Six, given for the encouragement of literary work in the schools of the State. Three scholarships of $\$ 150$ each are offered for the best short stories, essays, and poems in annual competition, and three scholarships of $\$ 100$ each for the second best in each class.

(7) Chemistry essay scholarships: Six, for the best essays written by students of chemistry who are enrolled in secondary schools in Vermont. Value, $\$ 150$ each. Awarded annually. The contest is arrazged and administered by the Headmasters' Club. 


\section{VIRGINIA}

College of William and Mary.-(1) High-school scholarships: Offered to a number of accredited high schools. Exempt students from payment of $\$ 75$ in fees for the session. Granted for 1 year only, but on the basis of special merit may be continued for 2 years. Holders must pass all of the work carried in any semester and make a quality point average of 4 or better. All students holding this scholarship are required to board in the college dining room and room in a college-owned dormitory.

(2) Ministerial scholarships: Students furnishing satisfactory evidence of their intention and fitness to enter the ministry are admitted upon the same terms as Virginia students holding State scholarships. (See p. 19.)

University of Virginia.-(1) Accredited school scholarships: For use in the college of arts and sciences and the department of engineering; one for each accredited public or private secondary school. Tenure, 1 year. Emolument, for Virginians, in the college of arts and sciences and the department of engineering, the remission of $\$ 60$ in fees; for nonresidents, in the college of arts and sciences, the remission of $\$ 200$ in fees; in the department of engineering, the remission of $\$ 150$ in fees. The holder must be a graduate of his school, must rank in the highest quarter of his class, and must enter the university immediately following his graduation. Appointments are made upon recommendation of the accredited schools.

(2) Virginia State medical scholarships: Two, awarded annually in the department of medicine, toward the close of the session, to students from Virginia, on the basis of rank and need, retroactive for the session. Tenure, 4 years, conditioned upon maintenance of satisfactory scholastic record. Emolument, remission of tuition fee.

Virginia Military Institute.-Army scholarships: Two, at annual value of $\$ 250$. Awarded to the sons of officers of the United States Army upon nominations of the Adjutant General of the Army.

Virginia Polytechnic Institute.-Undergraduate honor scholarships: Three, open to men and women. Awarded to students who lead the freshman, sophomore, and junior classes, and good for use during the following year. Annual value, $\$ 100$. Tenure, 1 year.

\section{WYOMING}

University of Wyoming.-High-school honor scholarships: Two for each 4-year high school in State, one for boys and one for girls. Awarded to members of graduating class who show high scholarship, evidence of growth, and qualities of leadership. Annual value covers fees amounting to $\$ 44$. Tenure, 4 years.

\section{Graduate Scholarships, Fellowships, and Assistantships}

\section{ALABAMA}

University of Alabama.-(1) Research fellowships in school of mines. Offered in cooperation with United States Bureau of Mines: Four, for research in the mining and metallurgy of the ores and mineral resources of Alabama and the South. Annual stipend, $\$ 540$.

(2) Assistantships in accounting, botany, chemistry, economics, education, engineering, English, geology, history, home economics, law, library, mathematics, medicine, modern languages, physics, physical education, psychology, sociology, and zoology. Annual stipend, $\$ 200$; not over 12 hours per week of service.

\section{ARIZONA}

University of Arizona -Fellowships, 22, as follows: Animal industry, 1, $\$ 480$; bacteriology, 1, $\$ 300$; botany, 1, $\$ 300$; Bureau of Mines, 2, $\$ 600$ each; chemistry, 3, \$300 each; civil engineering, 1, \$400; geology, 2, $\$ 400$ each; history, 
1, $\$ 400$; home economics, $1, \$ 400$; mining, engineering, and metallurgy, $1, \$ 400$; music, 1, $\$ 400$; nutrition, 1, $\$ 480$; observatory, 1, $\$ 400$; philosophy and psychology, 1, \$300; physical education for men, 2, \$400 each; physical education for women, 1, $\$ 400$; physics, $1, \$ 300$.

\section{ARKANSAS}

University of Arkansas.-Graduate scholarships: Five, offered in various departments. Annual stipend, $\$ 250$. The recipient renders a small amount of service to the department in which he is majoring.

\section{CALIFORNIA}

University of California.-(1) University fellowships: Ten, available in any academic department (or in professional schools, provided the student is engaged in research). Annual stipend, approximately $\$ 600$.

(2) Lick Observatory fellowships in astronomy: Two, yielding approximately $\$ 600$ each. Open to properly qualified graduate students in astronomy. Appointees devote their attention to graduate study and assist in the work of the Lick Observatory, at Mount Hamilton, Calif. They usually are also permitted to spend 1 semester of each year at Berkeley, to carry on study at the Students' Observatory.

(3) Teaching assistantships: Available in many departments. Annual stipend, $\$ 600$, or, in some cases, slightly less. Appointees devote about one-half of their time to teaching duties and the remainder to graduate work.

\section{COLORADO}

Colorado School of Mines.-Graduate fellowships: Offered in mining, metallurgy, geology, geophysics, and petroleum. Open to graduates of universities, colleges, and technical schools who have completed substantially the undergraduate work of the Colorado School of Mines and who are qualified to undertake research problems.

University of Colorado.-(1) University fellowships: Ten, annual stipend, $\$ 200$, plus free tuition and major department course fees. Not over 3 hours of service per week.

(2) Graduate scholarships: forty-five, provide for tuition and major department course fees.

(3) Research fellowships: Ten, annual stipend, $\$ 400$, plus free tuition and major department course fees. Not over 3 hours of service per week.

(4) Foreign student fellowship: Annual stipend, $\$ 400$, plus free tuition and major department course fees. Open to a properly qualified student from a foreign country.

\section{FLORIDA}

University of Florida.-(1) Graduate assistantships: Agriculture, seven, $\$ 600$ each; biology and geology, one, $\$ 500$; business administration and economics, two, $\$ 50$ each; chemistry, six, $\$ 500$ each; engineering (civil one, mechanical one), two, $\$ 500$ each; pharmacognosy and pharmacology, two, $\$ 500$ each; pharmacy, two, $\$ 500$ each; psychology, one, $\$ 400$; physics, four, $\$ 400$ each; sociology, one, $\$ 200$ (for second semester).

(2) Graduate scholarships: $15, \$ 250$ each. These scholarships may be in any department that offers major work for a master's degree. Students accepting them are not permitted to take other remunerative positions.

(3) Fellowships: Architecture and allied arts, one, $\$ 500$.

(4) Research assistantships: Business administration and economics, two, $\$ 400$ each. 


\section{IDAHO}

Oniversity of Idaho.-(1) Graduate scholarships: Annual stipend, \$250, plus fees; limited service.

(2) Graduate fellowships: Annual stipend, $\$ 500$, plus fees; limited service.

(3) Teaching fellowships: Annual stipend, $\$ 600$, plus fees. "Holders of teaching fellowships will not under normal circumstances find it possible to complete the requirements for the master's degree in less than 2 years."

(4) Graduate fellowships in school of mines: Two, offered in cooperation with United States Bureau of Mines. Annual stipend, $\$ 600$. Research related to mineral industry.

(5) Graduate fellowship in the college of agriculture, department of agronomy, for the purpose of conducting research in pea gemination and vitality: Candidates must have degree from agricultural college of recognized standing with a major in agronomy. Annual stipend, $\$ 600$.

(6) Graduate fellowship in the college of agriculture and the college of engineering, department of agricultural engineering, for the purpose of conducting research in field and processing machinery required for the production of field peas: Annual stipend, $\$ 300$. Candidate is enabled to secure his master's degree in 2 years. He must have a degree in agricultural engineering.

(7) Fellowship in entomology: Annual stipend, $\$ 450$. Candidates must have bachelor's degree from an agricultural college of recognized standing, with a major in entomology. Holder may secure master's degree in 1 year.

\section{ILLINOIS}

University of Illinois.-(1) Graduate scholarships: For first-year graduate students. Annual stipend, $\$ 300$ and freedom from tuition, incidental and laboratory fees.

(2) Graduate fellowships: Annual stipends, $\$ 500$ to $\$ 600$, with freedom from tuition, incidental and laboratory fees. Open to second- and third-year graduate students.

(3) Organio chemistry fellowships: Ten each year. Annual stipend, $\$ 600$.

(4) Research assistantships in engineering experiment station: A number of certain additional assistantships of varying amounts for special research work. Annual stipend of $\$ 600$ for half-time service.

Purdue University.-Assistantships: In allde partments students pursuing graduate studies and at the same time giving assistance in the work of the department in which they are studying receive some compensation, usually sufficient to pay fees and living expenses.

IOWA

Iowa State College of Agriculture and Mechanic Arts--(1) Teaching seholarships: Offered by departments of college. Annual stipend, \$225. Minimum requirement of 3 hours of teaching, or 6 hours in laboratory, per week, or other equivalent service. At present one.

(2) Teaching fellowships: One or more in scientific and technical departments. Annual stipend, \$450. Minimum requirement of 5 hours per week of teaching, or 12 hours in laboratory, or equivalent service. At present 29.

(3) Research scholarships: In agricultural and engineering experiment stations, industrial research, department of veterinary research, and certain other departments. Annual stipend, \$225. Scholars are expected to do their major work largely in connection with the experiment-station work being carried on and to be on duty except for such time as is required for the minor and supporting work. At present 14.

(4) Research fellowships (in same departments as above): Not commonly awarded except to those who have already had some graduate training. Annual stipend, \$450. (Service same as above.) At present 54 . 
(5) Special research and industrial fellowships: Several offered annually, either by the college or by other agencies, for study of special industrial problems. Stipend varies with nature and importance of work and the preparation of the fellow.

(6) Graduate assistantships in many of the college departments and in several sections of the agricultural and engineering experiment stations: Annual stipend, $\$ 540$ to $\$ 720$. Teaching in class or laboratory one-half of standard teaching schedule assigned to an instructor in the department in which he is employed, or performing similar duties. At present 70.

State University of Iowa.-As part of the general policy of education adopted by the State and as a means of honoring and encouraging students of high ability, the graduate college of the university offers the following appointments with stipends for the year 1935-36 (subject to modification without notice): 70 tuition scholarships; 60 tuition and room scholarships; 25 or more research assistantships on half time, $\$ 450$ a year; about 70 graduate assistantships on half time, $\$ 450$ a year; 25 or more research assistantships on quarter time, $\$ 225$ a year; research associateships, open only to holders of the doctorate, with varying stipends.

All of the above stipends carry a reduction of two-thirds in tuition, both for the academic year and for each of the summer sessions adjacent to the academic year for which the appointment is made.

Assistantships as a rule are open only to graduate students who have done a year of distinguished work in their department of this university or a university of equal rank.

KANSAS

Kansas State College of Agriculture and Applied science.-(1) Graduate assistantships: Six, annual stipend, $\$ 425$ to $\$ 510$; one-third time.

(2) Graduate research assistants: 12 , annual stipend, $\$ 425$ to $\$ 500$; onethird time.

University of Kansas.-(1) University fellowships: About 15, annual stipend, $\$ 250$; not exceeding 6 clock hours' service a week.

(2) Assistantships: Annual stipend, $\$ 250$ to $\$ 1,000$, depending upon amount of service rendered.

\section{KENTUOKY}

University of Kentucky.-(1) University scholarships: 10. Annual stipend, \$200

(2) University fellowships: Five, annual stipend, $\$ 400$.

(3) Registrar's fellowship: Annual stipend, $\$ 400$.

(4) Assistantships: Open to graduate students in many departments. Stipend, $\$ 400$ to $\$ 800$.

\section{LOUISIANA}

Louisiana State University.-(1) Graduate assistants and teaching fellows. Appointments open to graduates of Louisiana State University or of other colleges and universities. Made on a competitive basis, the previous academic records of the applicants being the determining factor. Annual stipend: $\$ 450$ to $\$ 720$. Appointees are required to give not more than 9 hours a week to class instruction, or not more than 16 hours a week to laboratory instruction. They may take not more than 18 semester-hours of work. Candidates for assistantships should have had at least 1 year of graduate work.

(2) Graduate fellows: Annual stipend $\$ 360$ to $\$ 450$. Appointees are required to give not more than 4 hours a week to class instruction, or more than 8 hours a week to laboratory instruction. They may take not more than 24 semester-hours of graduate work.

(3) Honorary graduate scholarships: Five, awarded each year to honor graduates of public institutions of higher learning in Louisiana. Annual 
stipend, $\$ 270$, with exemption from all university fees except the diploma fee. One each awarded to graduates of the following institutions: Louisiana Polytechnic Institute, Ruston; Louisiana State Normal College, Natchitoches; Southwestern Louisiana Institute, Lafayette. Two are open to the graduating class of Louisiana State University. The students nominated in each case must have made an average of not less than B during their junior and senior years.

MAINE

University of Maine.-(1) Trustee graduate scholarships: Eight, open to graduates of any college in the State of Maine. Annual value, a year's tuition.

(2) Maritime Provinces graduate scholarships: One available annually in each of the four academic divisions of the university, for graduates of the colleges and universities in the Provinces of New Brunswick, Nova Scotia, and Prince Edward's Island. Given on a competitive basis. Annual value, remission of tuition.

(3) Trustee fellowships: Three, annual value, \$500. Assigned annually on a competitive basis by a committee of the faculty of graduate study.

(4) Tuition scholarships for graduate study are available to faculty members of the State normal schools.

\section{MARYLAND}

University of Maryland.-(1) Fellowships: A number have been established. Annual stipend, $\$ 400$, and remission of all graduate fees except the diploma fee. Service not to exceed 12 clock hours per week.

(2) Teaching and research assistantships: A number available in several departments. Stipend varies with the services rendered. Some are for $\$ 800$ a year. The assistant in this class devotes one-half of his time to instruction or research in connection with experiment-station projects, and is required to spend 2 years in residence for the master's degree. All graduate fees except the diploma fee are remitted to all assistants, provided they are in full graduate status and are carrying programs leading directly to academic higher degrees.

\section{MICHIGAN}

University of Michigan.-(1) University fellowships: Limited number. Stipend, $\$ 350$ to $\$ 600$.

(2) State college fellowships: Candidates recommended by the faculties of the accredited colleges in the State of Michigan. Stipend, $\$ 300$ to $\$ 400$.

(3) University scholarships in the graduate school: Limited to 20. Scholars must be residents of Michigan entering graduate work immediately after graduation from one of the undergraduate courses in the university. Annual value, remission of semester fees.

(4) Assistantships in various departments: About 100 are appointed annually. Stipend, $\$ 100$ to $\$ 500$.

\section{MINNESOTA}

University of Minnesota.-(1) Administration fellowships: Four-One in office of the comptroller, one in the office of the registrar, one in the office of the dean of women, and one in the office of the dean of student affairs. Each of the fellowships require one-half of the time of the student, the remaining half being given to such other work as may be deemed advisable. Granted for a period of 2 academic years, or 18 continuous months. Annual stipend, $\$ 600$.

(2) Fellowships and assistantships: The following fellowships and assistantships, carrying stipends ranging from $\$ 225$ to $\$ 900$, are open to graduates of any acceptable college or university: 
(a) Assistants in agriculture and'home economics, 30; botany, 10; economics, 6; education, 10; engineering experiment station, 2; English, 6; geology and mineralogy, 4; mathematics, 1 ; medical school, 4; political science, 3; Scandinavian, 1; sociology, 1; zoology, 2.

(b) Teaching assistants in botany, 1; chemistry and chemical engineering, 32; German, 3; history, 7; mathematics, 1; physics, 14; political science, 1; psychology, 6; sociology, 1; zoology, 14.

(c) Teaching fellows in electrical engineering, 2; medical school, 36.

(d) Research fellows in engineering experiment station, three.

(e) Scholarships: Medical school, five.

(f) Fellows: Mayo Foundation, 193; Minneapolis General Hospital, 12; medical social work, 2.

\section{MISSOURI}

University of Missouri.-(1) University scholarships and fellowships: A limited number of each. Annual stipend, $\$ 300$ and $\$ 600$.

(2) Agricultural research fellowships and scholarships. A limited number available in all departments of the college of agriculture.

\section{MONTANA}

Montana School of Mines.-Fellowships: Several State bureau of mines fellowships are available each year to graduates of universities, colleges, and technical schools who are qualified to undertake research problems and who are candidates for the degree of master of science. Value, $\$ 480$; tenure, 9 month

\section{NEBRASKA}

University of Nebraska.-(1) University research fellowships: For students pursuing work for $\mathrm{Ph}$. D. Annual stipend, $\$ 500$, plus free tuition.

(2) Graduate teaching fellowships and scholarships: Stipend dependent upon kind and amount of assistance rendered. Part of stipend consists in remission of certain fees.

(3) Graduate scholarships for colleges of State: One allotted to each college and university in Nebraska. Selection made from the graduating class of the previous year. Scholarships carry exemption from payment of general fees. Sixteen were granted in 1934-35.

\section{NEW MEXICO}

University of New Mexico.-Graduate fellowships: Four to six. Annual stipend, $\$ 400$; limited service, as teachers or laboratory assistants in their major departments of study.

\section{NORTH OAROLINA}

University of North Carolina.-(1) University fellowships: 26. For men only. Annual stipend, $\$ 500$ and free tuition; limited teaching or laboratory service.

(2) Research assistantships: 10. In sociology and related fields. Candidates must have had at least 1 year of graduate work. Annual stipend, $\$ 500$ and remission of tuition and certain other expenses.

(3) University scholarships: Available to men and women. Annual stipend, remission of tutiton, $\$ 75$ a year.

(4) Teaching assistants: Annual stipend, $\$ 450$ and free tutition; approximately one-half time in teaching.

North Carolina State College of Agriculture and Engineering of the University of North Carolina.-(1) Fellowships: 11, at \$530 each. Laboratory service.

(2) Station fellowship: For a study in plant breeding. Stipend, $\$ 600$. 


\section{NORTH·DAKOTA}

North Dakota Agricultural College.-Experiment station fellowship: Annual stipend, \$500. Awarded each year to a graduate of the school of agriculture whose interests and training are such as to make him a suitable candidate for research work. The terms of the fellowship permit the student to register in the graduate department and complete the requirements for a master's degree in 12 months. Thesis to be on some experiment station problem.

University of North Dakota.-(1) Graduate fellowships and scholarships: Several. Annual stipend, $\$ 500$ to $\$ 1,200$; one-half time in service.

(2) Industrial fellowship: Annual stipend, $\$ 500$. Research on problems connected with development of resources and industries of State.

\section{OHIO}

Ohio State University.--(1) Graduate assistantships: A variable number. Annual stipend, $\$ 450$ and remission of all fees except matriculation and graduation; one-half time in service.

(2) University scholarships: A variable number. Annual stipend, $\$ 250$ and remission of all fees except matriculation and graduation.

(3) University fellowships: A variable number. Annual stipend, $\$ 400$ and remission of all fees except matriculation and graduation.

\section{OKLAHOMA}

University of Oklahoma.-(1) University scholarships: 20 or more. Annual stipend, free tuition and remission of all departmental and incidental fees, except that charge may be made for materials.

(2) Graduate assistantships: Annual stipend, $\$ 250$ to $\$ 1,200$, depending upon nature and amount of service rendered.

(3) Research scholarships and fellowships: 10 or more. Annual stipends: Scholarships, $\$ 150$ to $\$ 250$; fellowships, $\$ 300$ to $\$ 500$; remission of fees in major department in each case. Limited amount of service may be required.

(4) Fellowships in petroleum engineering. Several. Annual stipend, $\$ 600$ to $\$ 800$.

\section{OREGON}

Oregon State Agrioultural College.-(1) Graduate assistantships: 18; 9 at annual value of $\$ 500 ; 9$ at annual value of $\$ 250$.

(2) Research assistantships: Four; three at annual value of $\$ 500$; 1 at annual value of $\$ 361.90$.

University of Oregon.-(1) Graduate assistantships: 23. Annual stipend, $\$ 500$ (less 6.3-percent legislative cut in 1935-36). Approximately 18 hours per week service.

(2) Research assistantships: One. Annual stipend, $\$ 500$ (less 6.3-percent legislative cut in 1935-36). Approximately 18 hours per week service.

(3) Part-time graduate assistantships: Two. Carry a smaller stipend and fewer hours of work than full-time assistantships.

(4) Teaching fellowships: Three. Annual stipends average $\$ 650$ to $\$ 1,050$ (less 6.3-percent legislative cut in 1935-36). Open usually to candidates with master's degree or equivalent. Part-time teaching required.

(5) Graduate assistantships in the medical school (at Portland): Three with values from $\$ 501$ to $\$ 618.42$; five with values from $\$ 401$ to $\$ 500$; three with values from $\$ 168.28$ to $\$ 343.80$.

\section{PENNSYLVANIA}

Pennsylvania State College.-(1) Graduate assistantships: Number varies from year to year. Annual stipend, about $\$ 800$; service equivalent to one-half the duties required of instructors or full-time assistants. 
(2) Graduate scholarships: A limited number assigned to different departments. Carry exemption from graduate student and practicum fees; some service required.

(3) Graduate stipend scholarships: Number varies from year to year. Annual stipend, $\$ 300$; one-fourth time given to service.

\section{SOUTH DAKOTA.}

South Dakota State College of Agriculture and Mechanic Arts.-Graduate assistantships: Two. Annual stipend, \$500; one-half time in teaching.

South Dakota State School of Mines.-Fellowships in engineering: Two. Annual stipend, \$600; one-half time in laboratory service.

TEXAS

Agricultural and Mechanical College of Texas.-Graduate scholarships and fellowships: A limited number. Annual stipends, $\$ 405$. Amount of service determined by dean and department heads.

University of Texas.-(1) University advanced fellowships: Open only to graduate students of at least 1 year's standing. Annual stipend, $\$ 300$.

(2) University fellowships: Annual stipend, $\$ 200$.

UTAH

University of Utah.-Metallurgical research fellowships: Five. Awarded preferably to graduates of mining schools who have shown special aptitude for research in metallurgy. For cooperative research with the United States Bureau of Mines. Tuition and fees in metallurgy department.

\section{VIRGINIA}

University of Virginia.-(1) Service fellowships in biology: Five. Annual income $\$ 250$ to $\$ 750$. Holder must have a baccalaureate degree from a college or university of recognized standing, and must have received a thorough undergraduate training in biology. Service, not more than 15 hours a week.

(2) Service fellowships in chemistry: Several. Annual stipend, $\$ 450$, and exemption from tuition. Holder must have a baccalaureate degree from a college or university of recognized standing, and must have received a thorough undergraduate training in chemistry and physics. Service, not more than 15 hours a week.

(3) Service fellowships in economics: Two. Annual stipend, $\$ 450$. Holder must be a graduate student in economics and related subjects, and must devote a portion of his time to instructional work in the department.

(4) Service fellowships in physics: Seven. Annual stipends, $\$ 200$ to $\$ 500$. The amount of stipend in any one case is determined by the special fitness of the applicant and is subject to possible increase from year to year. Holder must have a baccalaureate degree and must pursue graduate studies in physics for his major subject. A student showing aptitude for research may have his teaching duties lightened.

(5) Rector and visitors' fellowships in the schools of English, English literature, and Romance languages: Three. Annual stipend, $\$ 170$, and remission of all fees. Holder must be a graduate student, and must devote a portion of his time to work connected with one of the designated schools.

(6) College fellowships: One for each of a list of colleges selected by the faculty. Annual stipends: For Virginians, the remission of the university fee, $\$ 50$; for non-Virginians, the remission of the tuition fee, $\$ 90$. The holders must be graduates of the selected colleges. 
Virginia Polytechnic Institute.-(1) Teaching fellowships: 15. Open to men and women who hold a bachelor's degree from the Virginia Polytechnic Institute or another accredited college. Annual value, $\$ 400$, together with remission of college fees. Tenure, 1 year, and may be renewed in exceptional cases. Service, a limited amount of instruction or laboratory work.

(2) Research fellowships: 12. Open to men and women who hold a bachelor's degree from Virginia Polytecnnic Institute or another accredited college. Annual value, $\$ 600$ and remission of college fees. Tenure, 1 year, and may be renewed in exceptional cases. Service, one-half time to research for which credit is allowed toward a graduate degree.

(3) Fellowships: Four, open to men and women who hold a bachelor's degree from the Virginia Polytechnic Institute or another accredited college. Annual value, $\$ 400$, together with remission of college fees. Tenure, 1 year, and may be renewed in exceptional cases. Holders must assist members of the faculty in their research projects to an extent not interfering with the pursuit of work toward a graduate degree.

\section{WASHINGTON}

State College of Washington.-(1) Teaching fellowships. In business administration, one at $\$ 350$; in botany, three at $\$ 350$ each; in chemistry, two at $\$ 350$ each; in zoology, one at $\$ 350$; in English, three at $\$ 350$ each; in geology, one at $\$ 350$; in the college of agriculture and agricultural experiment station, one at $\$ 1,020$; in the college of mechanic arts and engineering and the engineering experiment station, one, at $\$ 350$.

(2) Research fellowships: In the college of agriculture and the agricultural experiment station, three to five, at $\$ 510$ to $\$ 680$. In the college of mechanic arts and engineering and the engineering experiment station, one at $\$ 350$.

(3) College scholarships: Offered in many departments of the college to students from junior to graduate standing. Annual stipends, $\$ 100$ to $\$ 500$. A specified amount of work of instructional value is required.

University of Washington.-(1) Research fellowships: Five. In college of mines, for research in coal and clay, in cooperation with the United States Bureau of Mines. Annual stipend, \$714, and remission of tuition and fees.

(2) University teaching fellowships: In various departments. Annual stipends, $\$ 500$ to $\$ 700$; one-half time in service.

(3) Graduate scholarships: Open each year to students who perform service as laboratory assistants, assistants in charge of quiz sections, or readers. Annual stipends, $\$ 180$ to $\$ 360$, in proportion to service.

\section{WISCONSIN}

University of Wisconsin.-(1) University fellowships: 48. Annual stipend, $\$ 600$, equivalent of 1 hour of teaching daily.

(2) School of education fellowships: Two. For students interested primarily in problems of secondary-school teaching. Annual stipend, $\$ 600$.

(3) Graduate research fellowships in engineering: Three. Appointments for 2 years. Stipend, first year, $\$ 900$; second year, $\$ 1,100$; one-half time in service.

(4) Graduate scholarships: 23. Annual stipend, $\$ 250$.

(5) Honorary fellowships: 48 . Restricted to graduates of at least 1 year's standing who have already held academic honors, such as fellowships or teaching or research appointments. Carry remission of nonresident and general fees.

(6) Honorary scholarships: 23. Open only to persons who have received baccalaureate degree at least 1 year previous to their nomination. Carry remission of nonresident tuition and general fees. 


\title{
PART III: SCHOLARSHIPS AND FELLOWSHIPS AVAILABLE AT STATE-SUPPORTED HIGHER EDUCATIONAL INSTI- TUTIONS, 1934-35
}

\begin{abstract}
THERE ARE other sources of scholarship aid at State-supported
higher institutions than the States and the institutions themselves. Individuals, clubs, alumni associations, industrial organizations, and various other groups have given generous scholarship aid to publicly as well as privately supported colleges and universities. Usually the donors prescribe the conditions upon which the scholarships or fellowships are to be granted. Inasmuch as these conditions vary so greatly, it is not practicable to state them here, as has been done in the case of State scholarships. In the following tables, however, the data include figures for the scholarships and fellowships available from funds supplied from both State and private sources in 1934-35.
\end{abstract}


TABLE 2.-SCHOLARSHIPS AVAULABLE AT STATE-SUPPORTED UNIVERSTTIES AND COLLEGES, 1934-35

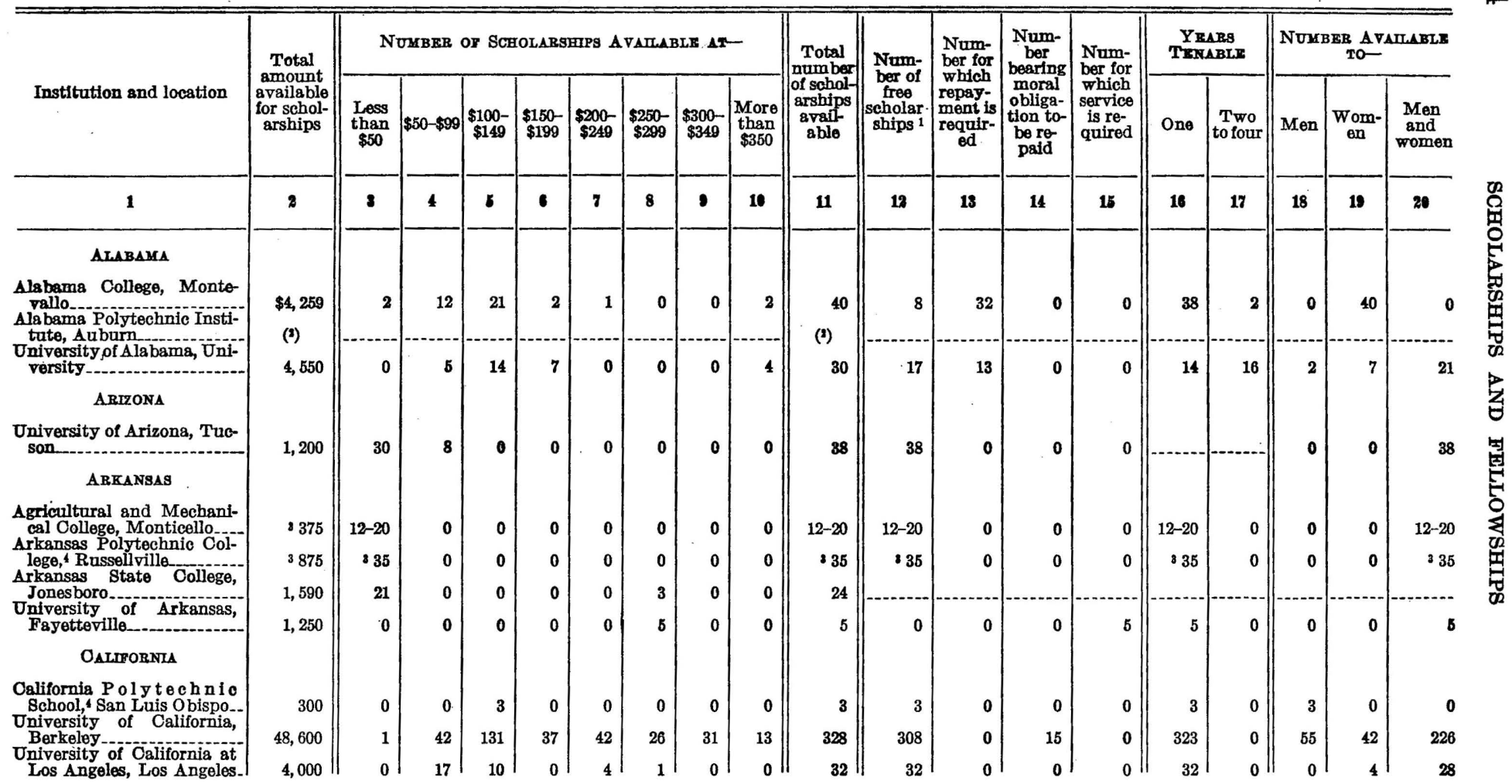




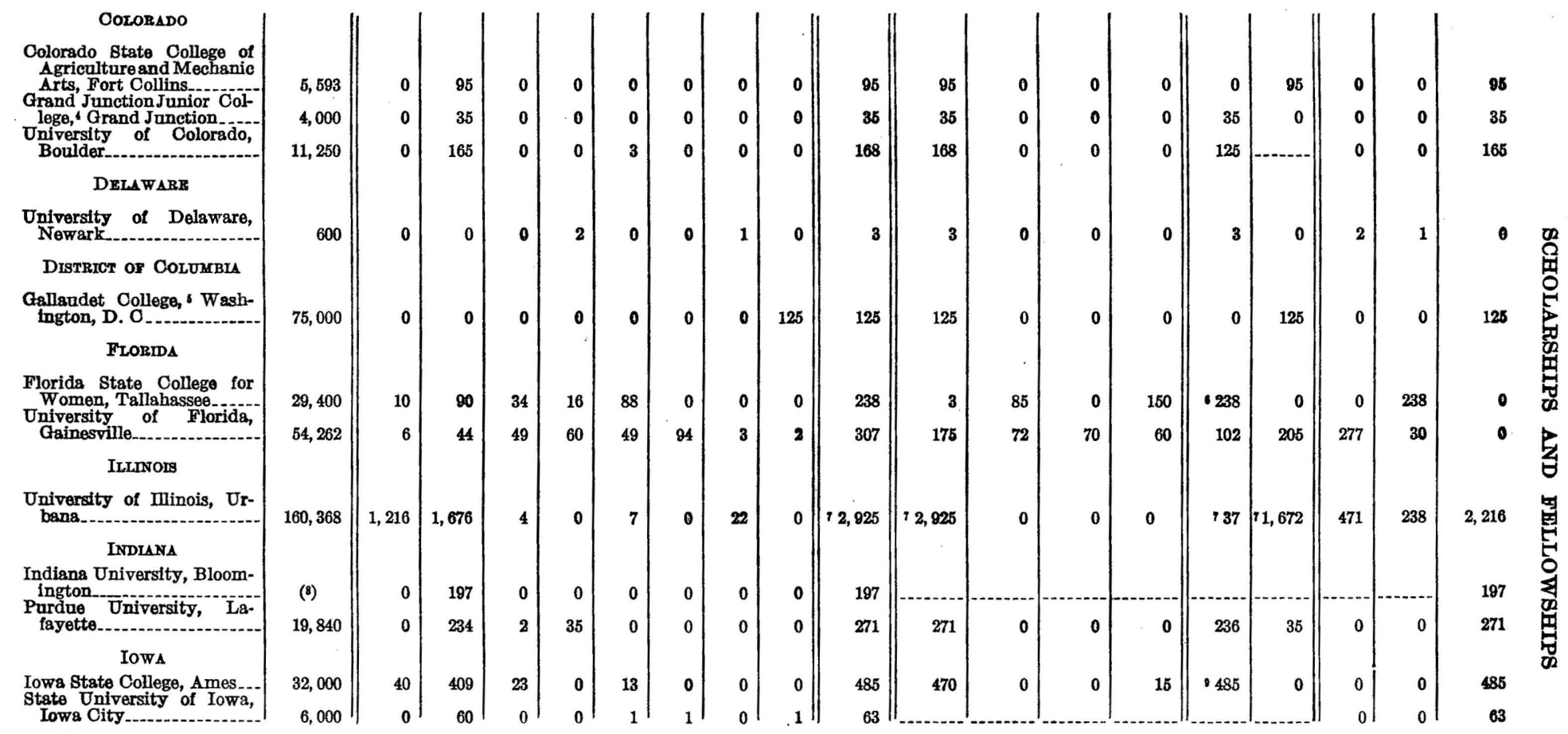

1 Repayment not required.

A limited number

Approximately.

- For the deaf. Under national control.

1216 are for use in the summer session onit.

"No cash appropriation." 


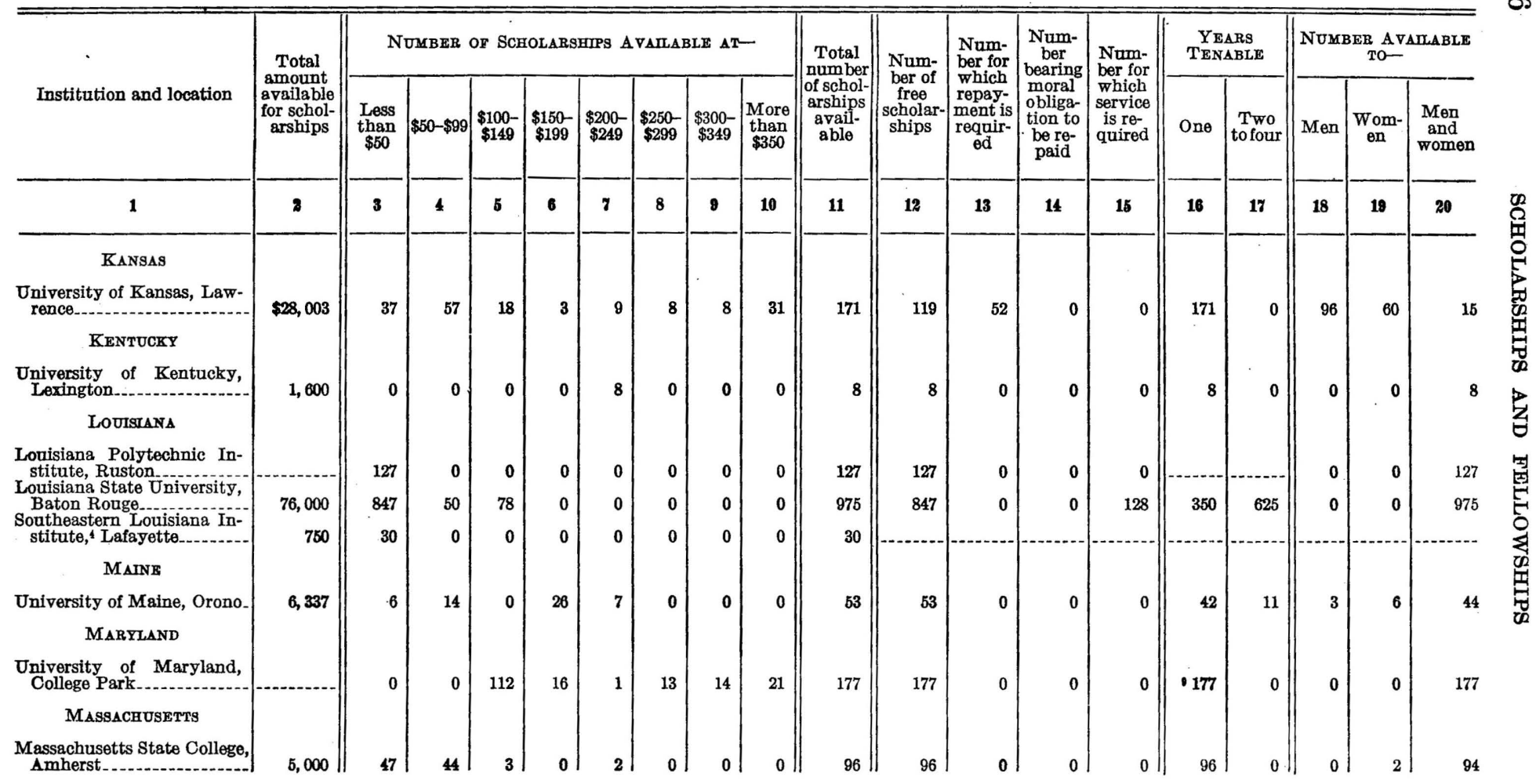




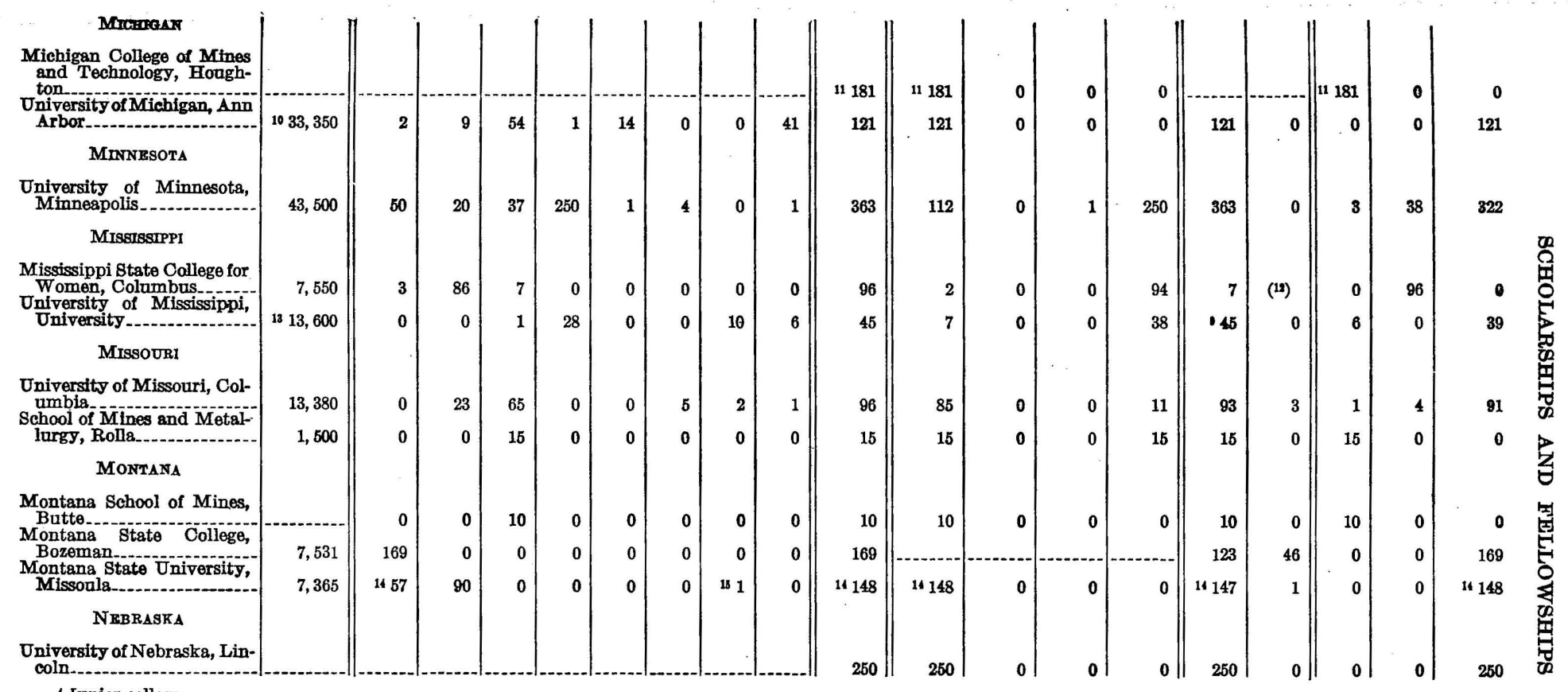

( Junior college.

9 May be renewed.

10 In addition, free tuition totaling $\$ 21,439$ granted in amounts ranging from $\$ 60$ to $\$ 160$ (figures for 1933-34).

of 12 No specified period; 3 years is usnally the limit but sometimes the time may be extended to 4 years.

13 Includes amount for 20 graduate assistantships, valued at $\$ 150$ to $\$ 199$.

14 Exclusive of military service scholarships.

4 Awarded every 3 years. 
TABL 2. SCHOLARSHIPS AVAILABLE AT STATE-SUPPORTED UNIVERSITIES AND COLLEGES, 1934-35-Continued

\begin{tabular}{|c|c|c|c|c|c|c|c|c|c|c|c|c|c|c|c|c|c|c|c|}
\hline \multirow{2}{*}{ Institution and location } & \multirow{2}{*}{$\begin{array}{c}\text { Total } \\
\text { amount } \\
\text { available } \\
\text { for schol- } \\
\text { arships }\end{array}$} & \multicolumn{8}{|c|}{ NUMBER OF SCHOLARSHIPS A VATHABLE AT- } & \multirow{2}{*}{\begin{tabular}{|c} 
Total \\
number \\
of schol- \\
arships \\
availa- \\
able
\end{tabular}} & \multirow{2}{*}{$\begin{array}{c}\text { Num- } \\
\text { ber of } \\
\text { free } \\
\text { scholar- } \\
\text { ships }\end{array}$} & \multirow{2}{*}{$\begin{array}{c}\text { Num- } \\
\text { ber for } \\
\text { which } \\
\text { repay- } \\
\text { ment is } \\
\text { requir- } \\
\text { ed }\end{array}$} & \multirow{2}{*}{$\begin{array}{c}\text { Num- } \\
\text { ber } \\
\text { beiring } \\
\text { moral } \\
\text { obliga- } \\
\text { tion to } \\
\text { be re- } \\
\text { paid }\end{array}$} & \multirow{2}{*}{$\begin{array}{l}\text { Num- } \\
\text { ber for } \\
\text { which } \\
\text { service } \\
\text { is re- } \\
\text { quired }\end{array}$} & \multicolumn{2}{|c|}{$\begin{array}{l}\text { YEARS } \\
\text { TENABLE }\end{array}$} & \multicolumn{3}{|c|}{$\underset{\text { TO- }}{\text { NUMBER AVATLBLE }}$} \\
\hline & & $\begin{array}{l}\text { Less } \\
\text { than } \\
\$ 50\end{array}$ & $\$ 50-\$ 99$ & $\mid$\begin{tabular}{|}
$\$ 100-$ \\
$\$ 149$
\end{tabular} & $\begin{array}{l}\$ 150- \\
\$ 199\end{array}$ & $\$ 200-$ & $\left|\begin{array}{|}\$ 250- \\
\$ 299\end{array}\right|$ & \begin{tabular}{|}
$\$ 300-$ \\
$\$ 349$
\end{tabular} & $\mid \begin{array}{c}\text { More } \\
\text { than } \\
\$ 350\end{array}$ & & & & & & One & $\begin{array}{c}\text { Two } \\
\text { to four }\end{array}$ & Men & $\begin{array}{c}\text { Wom- } \\
\text { en }\end{array}$ & $\begin{array}{l}\text { Men } \\
\text { and } \\
\text { women }\end{array}$ \\
\hline 1 & $\mathbf{2}$ & 3 & 4 & 5 & 6 & $\boldsymbol{y}$ & 8 & 9 & 10 & 11 & 12 & 13 & 14 & 15 & 16 & 17 & 18 & 19 & 20 \\
\hline NEVADA & & & & & & & & & & & & & & & & & & & \\
\hline $\begin{array}{l}\text { University of Nevada, Reno- } \\
\text { NEw HAMPSHrE } \\
\text { University of New Hamp- } \\
\text { shire, Durham. }\end{array}$ & $\$ 1,810$ & 1 & 275 & 39 & 0 & 25 & 0 & 2 & 0 & 340 & 340 & 0 & 1 & 0 & 21 & 0 & 5 & 2 & 14 \\
\hline NEW JERSEY & & & & & & & & & & & & & & & & & & & \\
\hline $\begin{array}{l}\text { Newrark College of Engineer- } \\
\text { ing, } 18 \text { Newark. } \\
\text { New Jersey College for } \\
\text { Women, Rutgers Uni- } \\
\text { versity, New Brunswick } \\
\text { Rutgers University (men's }\end{array}$ & 19,122 & 0 & 0 & 36 & 40 & 0 & 0 & $\theta$ & 0 & 121 & 121 & 0 & 40 & 0 & 121 & 0 & 0 & 121 & 40 \\
\hline $\begin{array}{c}\text { college), New Brunswick.- } \\
\text { NEW MExco }\end{array}$ & 55,935 & 1 & 18 & 218 & 3 & 45 & 1 & 0 & 51 & 337 & 337 & 0 & 0 & 0 & 337 & 0 & 337 & 0 & $\mathbf{0}$ \\
\hline $\begin{array}{l}\text { New Mexico College of Agri- } \\
\text { culture and Mechanic } \\
\text { Arts, State College }\end{array}$ & 100 & 0 & 0 & 1 & 0 & 0 & 0 & 0 & 0 & 1 & 1 & 0 & 0 & 0 & 1 & 0 & 0 & 1 & 0 \\
\hline $\begin{array}{l}\text { New Mexico Military Insti- } \\
\text { tute, }{ }^{4} \text { Roswell } \\
\text { University of New Mexico- }\end{array}$ & 600 & 0 & 0 & 0 & 0 & 3 & 0 & 0 & 0 & 3 & 3 & 0 & 0 & 0 & 3 & 0 & 1 & $\begin{array}{l}1 \\
0\end{array}$ & 0 \\
\hline Albuquerque...- & 2,828 & 8 & 2 & 1 & 3 & 4 & 0 & 4 & 0 & 22 & 22 & 0 & 0 & 0 & $\cdot 22$ & 0 & 7 & 8 & 7 \\
\hline NORTH OAROLINA & & & & & & & & & & & & & & & & & & & \\
\hline $\begin{array}{l}\text { University of North Caro- } \\
\text { lina, Chapel Hill } \\
\text { Woman's College of the Uni- } \\
\text { versity of North Carolina, } \\
\text { Greensboro. }\end{array}$ & 600 & 94 & 3 & 0 & 0 & 0 & 0 & 0 & 0 & 94 & 94 & 0 & 0 & 0 & 24 & 70 & 0 & 0 & 94 \\
\hline
\end{tabular}




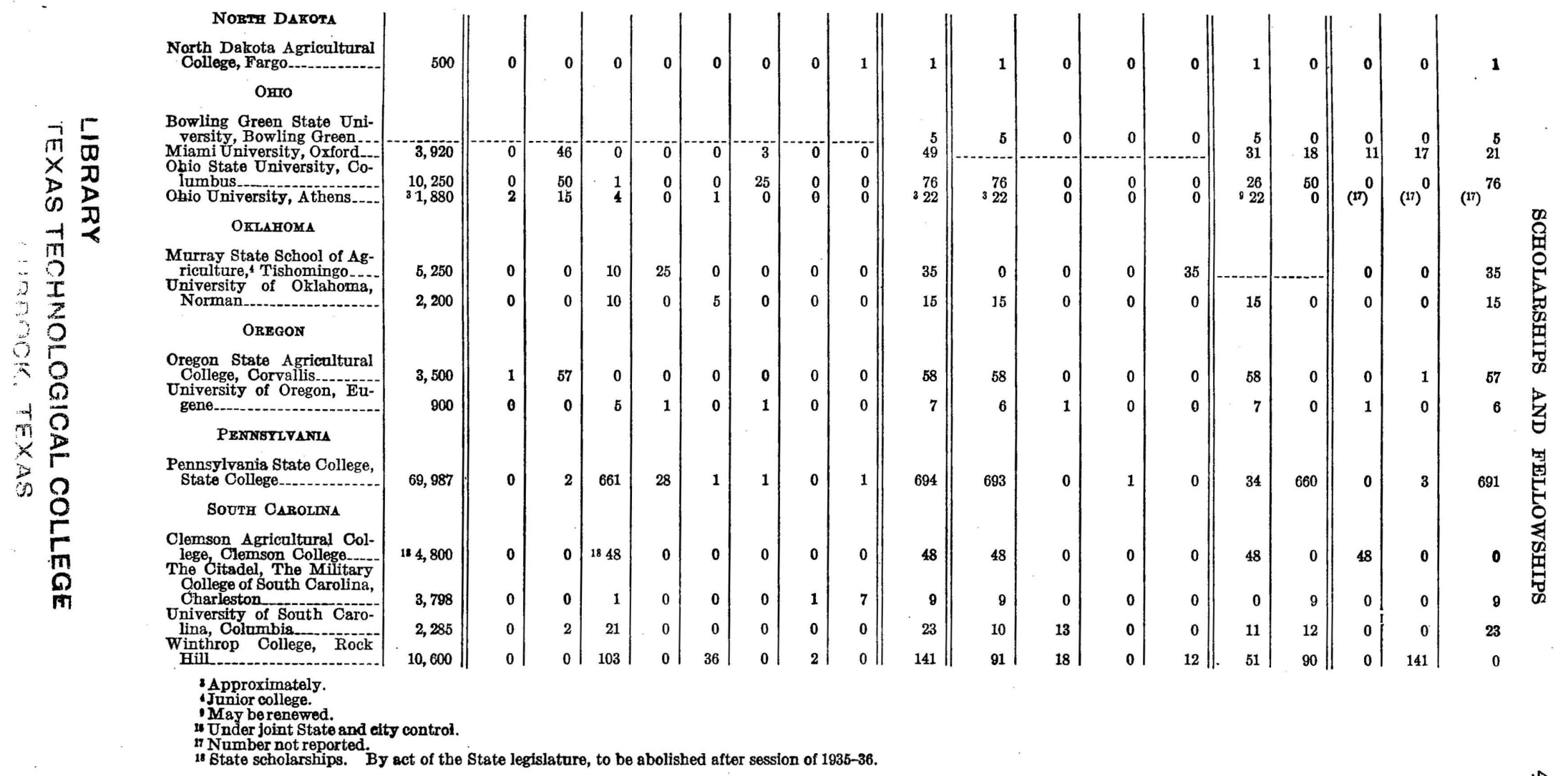


TABLE 2.-SCHOLARSHIPS AVAILABLE AT STATE-SUPPORTED UNIVERSITIES AND COLLEGES, 1934-35-Continued

\begin{tabular}{|c|c|c|c|c|c|c|c|c|c|c|c|c|c|c|c|c|c|c|c|}
\hline \multirow{2}{*}{ Institution and location } & \multirow{2}{*}{$\begin{array}{l}\text { Total } \\
\text { amount } \\
\text { available } \\
\text { for schol- } \\
\text { arships }\end{array}$} & \multicolumn{8}{|c|}{ NUMBER of SCHOLARSHIPS AVATLBLE AT } & \multirow{2}{*}{\begin{tabular}{||} 
Total \\
number \\
of schol- \\
arships \\
avail- \\
able
\end{tabular}} & \multirow{2}{*}{$\begin{array}{c}\text { Num- } \\
\text { ber of } \\
\text { free } \\
\text { scholar- } \\
\text { ships }\end{array}$} & \multirow{2}{*}{$\begin{array}{l}\text { Num- } \\
\text { ber for } \\
\text { which } \\
\text { repay- } \\
\text { ment is } \\
\text { requir- } \\
\text { ed }\end{array}$} & \multirow{2}{*}{$\begin{array}{l}\text { Num- } \\
\text { ber } \\
\text { bearing } \\
\text { morolal } \\
\text { obliga. } \\
\text { tion to } \\
\text { be re- } \\
\text { paid }\end{array}$} & \multirow{2}{*}{\begin{tabular}{|c|} 
Num- \\
buer for \\
which \\
service \\
is re- \\
quired \\
quired
\end{tabular}} & \multicolumn{2}{|c|}{$\begin{array}{c}\text { YRARS } \\
\text { TKMNABLE }\end{array}$} & \multicolumn{3}{|c|}{$\underset{\text { TO- }}{\text { NUMBER AVATABLI }}$} \\
\hline & & $\begin{array}{l}\text { Less } \\
\text { than } \\
\$ 50\end{array}$ & $\$ 50-\$ 99$ & $\$ \$ 1149-$ & $\$ 150-$ & $\$ \$ \$ 240-$ & $\$$ & $\begin{array}{l}\$ 300- \\
\$ 349\end{array}$ & $\begin{array}{l}\text { More } \\
\text { than } \\
\$ 350\end{array}$ & & & & & & One & $\left|\begin{array}{c}\text { Two } \\
\text { to four }\end{array}\right|$ & Men & $\begin{array}{c}\text { Wom- } \\
\text { en }\end{array}$ & $\begin{array}{l}\text { Men } \\
\text { and } \\
\text { women }\end{array}$ \\
\hline 1 & 2 & 3 & 4 & 5 & 0 & 7 & 8 & 9 & 10 & 11 & 12 & 13 & 14 & 15 & 16 & 17 & 18 & 10 & 20 \\
\hline TENnessez & \multirow{4}{*}{$\$ 1,730$} & \multirow{3}{*}{1} & \multirow{3}{*}{2} & \multirow[b]{2}{*}{9} & \multirow{3}{*}{3} & \multirow{3}{*}{0} & \multirow[b]{2}{*}{1} & \multirow[b]{2}{*}{0} & \multirow[b]{2}{*}{0} & \multirow{3}{*}{16} & \multirow[b]{2}{*}{15} & \multirow[b]{2}{*}{0} & \multirow[b]{2}{*}{0} & \multirow[b]{2}{*}{1} & \multirow{2}{*}{\multicolumn{2}{|c|}{14}} & \multirow[b]{2}{*}{0} & \multirow[b]{2}{*}{1} & \multirow[b]{2}{*}{15} \\
\hline $\begin{array}{c}\text { University of Tennessee, } \\
\text { Knoxville_ }\end{array}$ & & & & & & & & & & & & & & & & & & & \\
\hline TEXAS & & & & & & & & & & & & & & & & & & & \\
\hline $\begin{array}{c}\text { Agricultural and Mechani- } \\
\text { cal College of Texas, Col- } \\
\text { lege Station } \\
\text { John Tarleton Agricultural }\end{array}$ & & 0 & 18 & 0 & 0 & 0 & 0 & 0 & 0 & 18 & 18 & 0 & 0 & 0 & 1018 & 0 & 18 & 0 & $\mathbf{0}$ \\
\hline $\begin{array}{l}\text { John Tarleton Agricultural } \\
\text { College, Stephenville..... }\end{array}$ & 540 & 54 & 0 & 0 & 0 & 0 & 0 & 0 & 0 & 54 & & & & & 54 & 0 & 0 & 0 & 54 \\
\hline $\begin{array}{l}\text { Texas College of Arts and } \\
\text { Industries, Kingsille } \\
\text { Texas States College for Wom- } \\
\text { en Dente College }\end{array}$ & $(20)$ & ${ }_{(20)}^{25}$ & 0 & 0 & 0 & 0 & 0 & 0 & 0 & ${ }_{(20)}^{25}$ & ${ }_{(20)}^{25}$ & 0 & 0 & 0 & $\begin{array}{r}25 \\
(20)\end{array}$ & 0 & 0 & 0 & 25 \\
\hline $\begin{array}{l}\text { en, Denton } \\
\text { Texas Technological Coliege, } \\
\text { Lnbbock }\end{array}$ & (20) & $(20)$ & & & & & & & & $(20)$ & $(20)$ & & & & & & & & \\
\hline Oniversity of Texas, Austin & 10,581 & 0 & 85 & 4 & $\overline{2}$ & 4 & 1 & $\mathrm{i}$ & 5 & 102 & 102 & 0 & 0 & 0 & 101 & 1 & $i$ & 6 & 95 \\
\hline UTAH & & & & & & & & & & & & & & & & & & & \\
\hline $\begin{array}{l}\text { Dixie Junior College, } \\
\text { George } \\
\text { Snow College, }\end{array}$ & $\begin{array}{r}770 \\
1000\end{array}$ & ${ }_{0}^{6}$ & $\frac{14}{20}$ & $\begin{array}{l}0 \\
0\end{array}-1-1$ & $\begin{array}{l}0 \\
0\end{array}$ & $\begin{array}{l}0 \\
0\end{array}$ & $\begin{array}{l}0 \\
0\end{array}$ & $\begin{array}{l}0 \\
0\end{array}$ & $\begin{array}{l}0 \\
0\end{array}$ & $\begin{array}{l}20 \\
20\end{array}$ & ${ }_{20}^{20}$ & $\begin{array}{l}0 \\
0\end{array}$ & $\begin{array}{l}0 \\
0\end{array}$ & $\begin{array}{l}0 \\
0\end{array}$ & ${ }_{20}^{20}$ & $\begin{array}{l}0 \\
0\end{array}$ & $\begin{array}{l}0 \\
0 \\
\end{array}$ & $\begin{array}{l}0 \\
0\end{array}$ & 20 \\
\hline 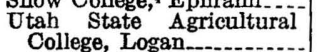 & 2,040 & 63 & 10 & 2 & 0 & 0 & 0 & 0 & 0 & 7 & 70 & 0 & 0 & 0 & ${ }_{75}{ }^{20}$ & 0 & 0 & 0 & $\begin{array}{l}20 \\
75\end{array}$ \\
\hline $\begin{array}{l}\text { Branch Agricultural } \\
\text { College, Cedar City } \\
\text { University of Utah, Salt }\end{array}$ & 1,050 & 30 & 0 & 0 & 0 & 0 & 0 & 0 & 0 & $\begin{array}{r}30 \\
231\end{array}$ & $\begin{array}{r}30 \\
231\end{array}$ & 0 & 0 & 0 & 30 & $\begin{array}{r}0 \\
100\end{array}$ & 15 & $\begin{array}{c}15 \\
0\end{array}$ & ${ }^{0}$ \\
\hline
\end{tabular}




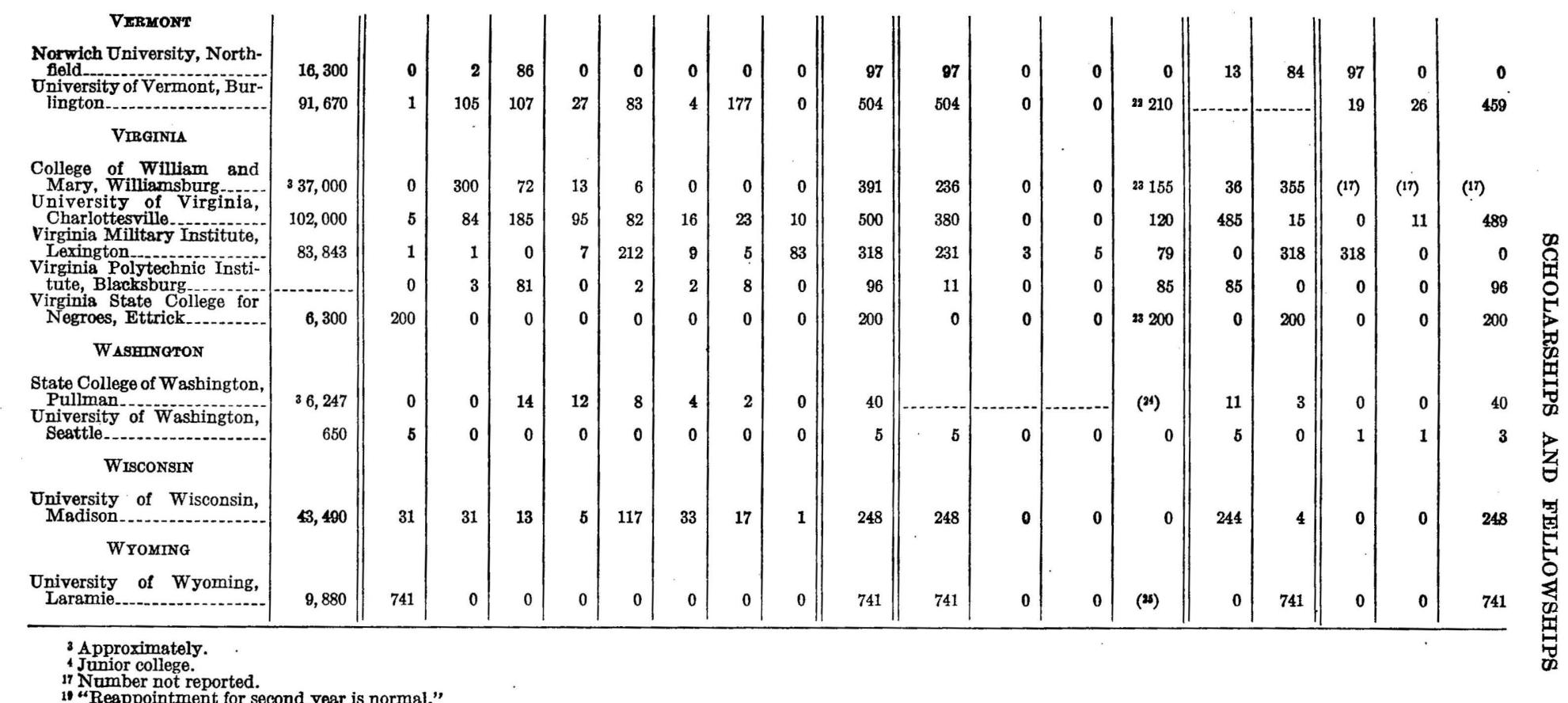

17 Number not reported.

20 Each State college may award 1 scholarship a year, amounting to $\$ 50$ tuition charges, to each first-class high school in the State. The colleges did not report the number arded in $1934-35$.
210 percent of amcunt of total registration. $\$ 5,456.76$ in $1934-35$.

22210 are State scholarships. Holders of 160 teacher-training scholarships must teach 1 year in the State for each year the soholarships are held or refund the amount received. Holders of 50 medical scholarships must practice 1 year in the state for each year the

24 Mostly loboratory or research assistants.

26 Few render service. 
TABLE 3.-FELLOWSHIPS AND GRADUATE SCHOLARSHIPS AVAILABLE AT STATE-SUPPORTED UNIVERSITIES AND COLLEGES, 1934-35

\begin{tabular}{|c|c|c|c|c|c|c|c|c|c|c|c|c|c|c|c|}
\hline \multirow[b]{2}{*}{ Institution } & \multirow{2}{*}{$\begin{array}{l}\text { Trotal } \\
\text { amount } \\
\text { available } \\
\text { for } \\
\text { fellow- } \\
\text { ships }\end{array}$} & \multicolumn{6}{|c|}{ 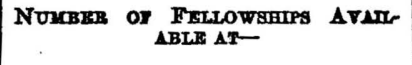 } & \multirow{2}{*}{$\begin{array}{l}\text { Total } \\
\text { num- } \\
\text { ber of } \\
\text { fellow- } \\
\text { ships } \\
\text { arail- } \\
\text { able }\end{array}$} & \multirow{2}{*}{$\begin{array}{c}\text { Num- } \\
\text { ber of } \\
\text { free } \\
\text { fellow- } \\
\text { ships }\end{array}$} & \multirow{2}{*}{$\begin{array}{l}\text { Num- } \\
\text { ber for } \\
\text { which } \\
\text { service } \\
\text { is re- } \\
\text { quired }\end{array}$} & \multicolumn{2}{|c|}{$\underset{\text { TENABLI }}{\text { YRARS }}$} & \multicolumn{3}{|c|}{$\underset{\text { NOGGBR }}{\text { NOATIABLR }}$} \\
\hline & & $\begin{array}{l}\$ 299 \\
\text { or } \\
\text { less }\end{array}$ & $\$ 300-$ & $\$ 400$ & 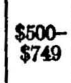 & $\$ \$ \$ 70-$ & $\begin{array}{l}\$ 1,000 \\
\text { and } \\
\text { over }\end{array}$ & & & & One & $\begin{array}{l}\text { Two } \\
\text { or } \\
\text { more }\end{array}$ & Men & Women & $\begin{array}{c}\text { Men } \\
\text { and } \\
\text { women }\end{array}$ \\
\hline $\mathbf{1}$ & 9 & 3 & 4 & $\mathbf{5}$ & - & 7 & 8 & ? & 10 & $\mathbf{1 1}$ & 12 & 13 & 14 & $15 \cdot$ & 16 \\
\hline $\begin{array}{l}\text { University of Alabama } \\
\text { University of Arizona } \\
\text { University of Oalifornia } \\
\text { University of California at Ios Angeles } \\
\text { University of Colorado }\end{array}$ & $\begin{array}{r}\$ 29,789 \\
6,240 \\
40,995 \\
11,200 \\
39,121\end{array}$ & $\begin{array}{r}171 \\
3 \\
12 \\
0 \\
5\end{array}$ & $\begin{array}{r}27 \\
0 \\
\mathbf{3} \\
0 \\
0\end{array}$ & $\begin{array}{r}7 \\
11 \\
4 \\
14 \\
10\end{array}$ & $\begin{array}{r}10 \\
2 \\
34 \\
11 \\
5\end{array}$ & $\begin{array}{l}6 \\
0 \\
9 \\
0 \\
5\end{array}$ & $\begin{array}{r}1 \\
0 \\
7 \\
0 \\
19\end{array}$ & $\begin{array}{r}222 \\
16 \\
69 \\
25 \\
44\end{array}$ & $\begin{array}{r}0 \\
0 \\
163 \\
0 \\
17\end{array}$ & $\begin{array}{r}222 \\
16 \\
0 \\
25 \\
27\end{array}$ & $\begin{array}{r}222 \\
16 \\
0 \\
25 \\
24\end{array}$ & $\begin{array}{r}0 \\
0 \\
69 \\
0 \\
20\end{array}$ & $\begin{array}{l}0 \\
2 \\
1 \\
0 \\
0\end{array}$ & $\begin{array}{l}0 \\
3 \\
4 \\
0 \\
0\end{array}$ & $\begin{array}{r}222 \\
11 \\
64 \\
25 \\
\mathbf{4 4}\end{array}$ \\
\hline $\begin{array}{l}\text { Gallaudet College }{ }^{2} \\
\text { Florida State College for Women }\end{array}$ & $\begin{array}{l}\mathbf{6}, 000 \\
\mathbf{1}, 600 \\
\mathbf{9}, 460\end{array}$ & $\begin{array}{l}0 \\
0 \\
8\end{array}$ & $\begin{array}{r}0 \\
1 \\
10\end{array}$ & $\begin{array}{l}0 \\
0 \\
6\end{array}$ & $\begin{array}{l}0 \\
2 \\
4\end{array}$ & $\begin{array}{l}0 \\
0 \\
0\end{array}$ & $\begin{array}{l}6 \\
0 \\
0\end{array}$ & $\begin{array}{r}0 \\
3 \\
28\end{array}$ & $\begin{array}{l}\mathbf{0} \\
\mathbf{0}\end{array}$ & $\begin{array}{l}6 \\
3\end{array}$ & $\begin{array}{l}6 \\
3\end{array}$ & $\begin{array}{l}\mathbf{0} \\
\mathbf{0}\end{array}$ & $\begin{array}{l}0 \\
0\end{array}$ & $\begin{array}{l}\mathbf{0} \\
\mathbf{3}\end{array}$ & 6 \\
\hline $\begin{array}{l}\text { University of Idaho } \\
\text { University of Illinois.-.... }\end{array}$ & $\begin{array}{r}5,921 \\
19,450\end{array}$ & $\begin{array}{l}0 \\
0\end{array}$ & $\begin{array}{l}1 \\
0\end{array}$ & $\begin{array}{l}9 \\
0\end{array}$ & $\begin{array}{r}3 \\
34\end{array}$ & $\begin{array}{l}0 \\
1\end{array}$ & $\begin{array}{l}0 \\
0\end{array}$ & $\begin{array}{l}13 \\
35\end{array}$ & $\begin{array}{r}0 \\
35\end{array}$ & ${ }_{0}^{13}$ & 35 & $\begin{array}{l}1 \\
0\end{array}$ & $\begin{array}{l}3 \\
0 \\
0\end{array}$ & $\begin{array}{l}2 \\
0\end{array}$ & $\begin{array}{r}8 \\
35\end{array}$ \\
\hline $\begin{array}{l}\text { Iowa State College } \\
\text { State University of Iowa }\end{array}$ & $\begin{array}{r}37,400 \\
473,000 \\
2,112\end{array}$ & 0 & 0 & 83 & 0 & 0 & 0 & $\begin{array}{r}83 \\
184\end{array}$ & $\begin{array}{r}0 \\
57\end{array}$ & $\begin{array}{r}83 \\
127\end{array}$ & 383 & 0 & $\begin{array}{l}0 \\
0\end{array}$ & $\begin{array}{l}0 \\
0\end{array}$ & $\begin{array}{r}83 \\
6184 \\
6\end{array}$ \\
\hline $\begin{array}{l}\text { lege of Agriculture and Applied Science } \\
\text { nsas. }\end{array}$ & $\begin{array}{l}2,112 \\
3,600\end{array}$ & 15 & 0 & 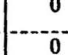 & 0 & 0 & $\begin{array}{c}0 \\
0-\end{array}$ & $\begin{array}{r}7 \\
718 \\
15\end{array}$ & $\begin{array}{l}0 \\
0 \\
0\end{array}$ & $\begin{array}{r}0 \\
718 \\
15\end{array}$ & $\begin{array}{r}6 \\
-15\end{array}$ & 0 & $\begin{array}{l}0 \\
3 \\
0\end{array}$ & $\begin{array}{l}0 \\
5 \\
0\end{array}$ & $\begin{array}{l}6 \\
10 \\
15\end{array}$ \\
\hline $\begin{array}{l}\text { University of Kentucky } \\
\text { Lotisiana Polytechnic Institute }\end{array}$ & 2,000 & $\begin{array}{r}0 \\
95\end{array}$ & $\begin{array}{l}\mathbf{0} \\
0\end{array}$ & $\begin{array}{l}5 \\
0\end{array}$ & 0 & $\stackrel{0}{0}$ & $\begin{array}{l}0 \\
0\end{array}$ & 95 & $\begin{array}{l}5 \\
0\end{array}$ & $\begin{array}{r}0 \\
95\end{array}$ & 5 & 0 & $\begin{array}{r}0 \\
68\end{array}$ & $\begin{array}{l}0 \\
5\end{array}$ & $\stackrel{5}{22}$ \\
\hline ty-. & 98,000 & 36 & 91 & 68 & 17 & 18 & 1 & 231 & 0 & 231 & 231 & 0 & 0 & 0 & 231 \\
\hline $\begin{array}{l}\text { Southwestern Louisiana Institute } \\
\text { University of Maine }\end{array}$ & $\begin{array}{r}24,445 \\
1,500\end{array}$ & $\begin{array}{r}208 \\
0\end{array}$ & $\begin{array}{l}0 \\
0\end{array}$ & $\begin{array}{l}0 \\
0\end{array}$ & $\begin{array}{l}\mathbf{0} \\
\mathbf{3}\end{array}$ & $\begin{array}{l}0 \\
0\end{array}$ & $\begin{array}{l}0 \\
0\end{array}$ & $\begin{array}{r}208 \\
3\end{array}$ & $\begin{array}{l}0 \\
3\end{array}$ & $\begin{array}{r}208 \\
0\end{array}$ & 3 & 0 & $\begin{aligned} 93 \\
0\end{aligned}$ & $\begin{array}{r}62 \\
0\end{array}$ & $\begin{array}{l}53 \\
3\end{array}$ \\
\hline $\begin{array}{l}\text { University of Maryland } \\
\text { Massachusetts State College } \\
\text { University of Michigan } \\
\text { University of Minnesota } \\
\text { Mississippi State Oollege for Women }\end{array}$ & $\begin{array}{r}8,400 \\
17,300 \\
40,065 \\
57,900 \\
160\end{array}$ & $\begin{array}{r}0 \\
1 \\
2 \\
18 \\
1\end{array}$ & $\begin{array}{r}0 \\
0 \\
15 \\
11 \\
0\end{array}$ & $\begin{array}{r}21 \\
0 \\
35 \\
7 \\
0\end{array}$ & $\begin{array}{r}0 \\
22 \\
21 \\
23 \\
0\end{array}$ & $\begin{array}{l}0 \\
2 \\
6 \\
6 \\
0\end{array}$ & $\begin{array}{r}0 \\
2 \\
3 \\
14 \\
0\end{array}$ & $\begin{array}{r}21 \\
27 \\
82 \\
79 \\
1\end{array}$ & $\begin{array}{l}0 \\
0 \\
0 \\
0 \\
0\end{array}$ & $\begin{array}{r}21 \\
27 \\
82 \\
79 \\
1\end{array}$ & $\begin{array}{c}327 \\
(3) \\
79 \\
31\end{array}$ & $\begin{array}{r}\text { (3) } \\
0 \\
0\end{array}$ & $\begin{array}{l}0 \\
0 \\
0 \\
0 \\
0\end{array}$ & $\begin{array}{l}0 \\
0 \\
0 \\
0 \\
1\end{array}$ & $\begin{array}{r}21 \\
27 \\
82 \\
79 \\
0\end{array}$ \\
\hline $\begin{array}{l}\text { School of Mines and Metallurgy of the University of Missouri. } \\
\text { Montana School of Mines } \\
\text { Montana State College } \\
\text { Montana State University } \\
\text { University of Nebraska }\end{array}$ & $\begin{array}{r}5,200 \\
2,250 \\
425 \\
\hdashline 38,568\end{array}$ & $\begin{array}{r}0 \\
0 \\
0 \\
0 \\
23\end{array}$ & $\begin{array}{r}0 \\
0 \\
0 \\
0 \\
73\end{array}$ & $\begin{array}{l}0 \\
5 \\
1 \\
0 \\
0\end{array}$ & $\begin{array}{l}6 \\
0 \\
0 \\
0 \\
4\end{array}$ & $\begin{array}{l}2 \\
0 \\
0 \\
1 \\
0\end{array}$ & $\begin{array}{l}0 \\
0 \\
0 \\
0 \\
0\end{array}$ & $\begin{array}{r}8 \\
5 \\
1 \\
1 \\
10100\end{array}$ & $\begin{array}{c}0 \\
-1 \\
1 \\
7\end{array}$ & $\begin{array}{r}8 \\
0 \\
0 \\
93\end{array}$ & $\begin{array}{r}8 \\
5 \\
81 \\
01\end{array}$ & $\begin{array}{l}0 \\
0 \\
0 \\
0\end{array}$ & $\begin{array}{l}8 \\
5 \\
1 \\
0 \\
0\end{array}$ & $\begin{array}{l}0 \\
0 \\
0 \\
0 \\
0\end{array}$ & $\begin{array}{r}0 \\
0 \\
0 \\
1 \\
10100\end{array}$ \\
\hline
\end{tabular}


Ratgers Universitty (men's college)

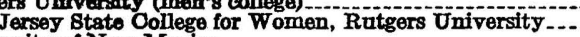
New York State Conlexo of Forestry at Byracnse University.

University of North Carolins.

oman's College of the University of North Carolina

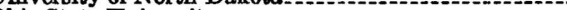

Ohio State University....

niversity of Oklahoma

regon Stato Agricultural College

Pennsylvania State Coll

Clemson Agricult

South Dakota State School of Mines

University of South Dakota

Agricultural and Mechanical College of Texas............................

Texas Technological College

University of Texas.-.

University of Utah

University of Vermont.

Virginia Polytechnic Institute

University of Wisconsin State College of Agriculture and Engineering of the University

tra College of Washington

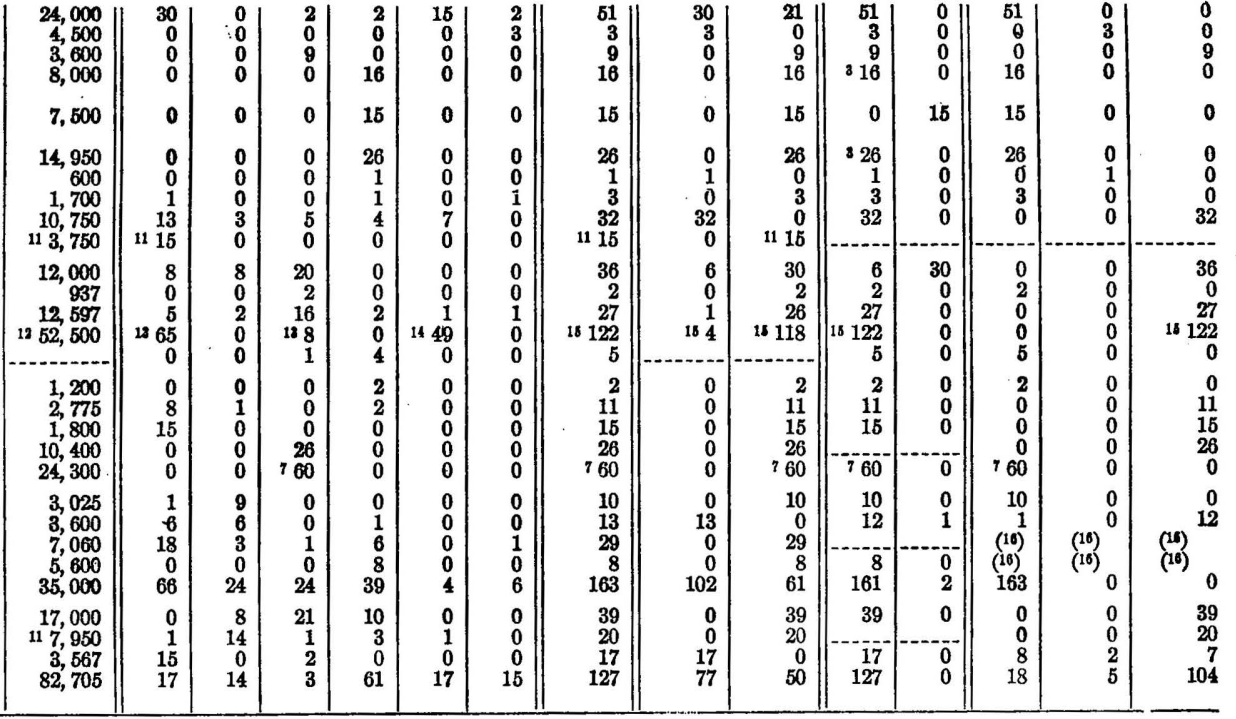

16 others carry a moral obligation to be repaid.

2 For the deaf. Under national control.

\$ 510,000 for followships; $\$ 63,000$ for research assistants and assaciates, and graduate assistants.

I Of these; 57 allowh

- Decided each year by State board of regents.

Assistantships.

Awarded every 2 years.

A Awarded every 4 years.

the $\$ 38,568, \$ 2,600$ is for fellowships, and $\$ 35,968$ for graduate asssitantships.

11 Approximately.

18 Graduate scholars and assistants.

144 fellowships, 45 graduate scholars and assistants.

is 4 fellowships, 118 graduate scholars and assistants 
Scholarships, fellowships, and assistantships in the following special fields are offered by the institutions listed in the preceding tables. The number of offerings in special fields are included in the figures given in the tables.

TABLE 4.-SCHOLARSHIPS AND FELLOWSHIPS AT STATE-SUP-
PORTED UNIVERSITIES AND COLLEGES DESIGNATED FOR STUDY IN SPECIAL FIELDS

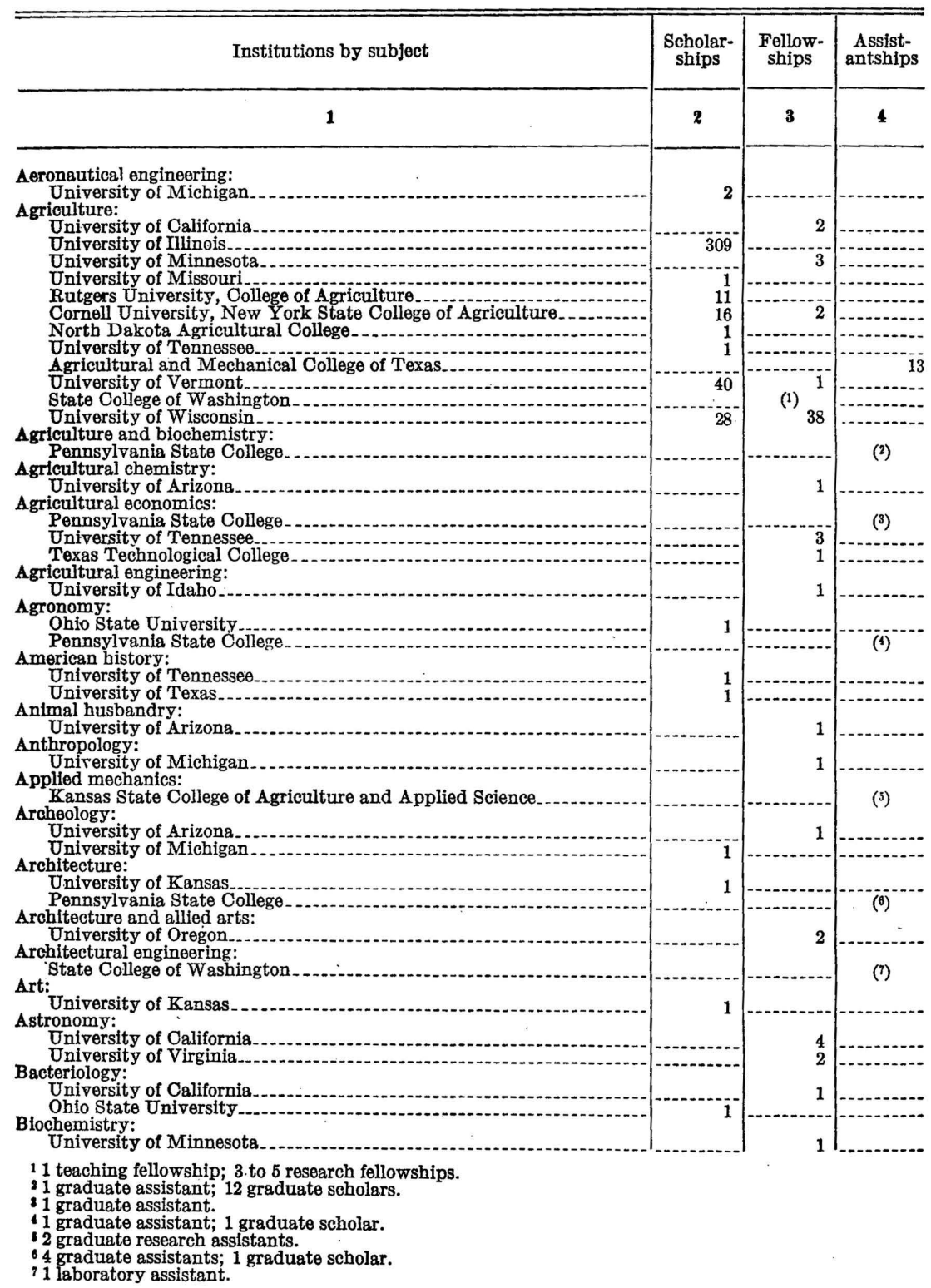




\section{TABLE 4--SCHOLARSHIPS AND FELLOWSHIPS AT STATE-SUP- PORTED UNIVERSITIES AND COLLEGES DESIGNATED FOR STUDY IN SPECIAL FIELDS-Continued}

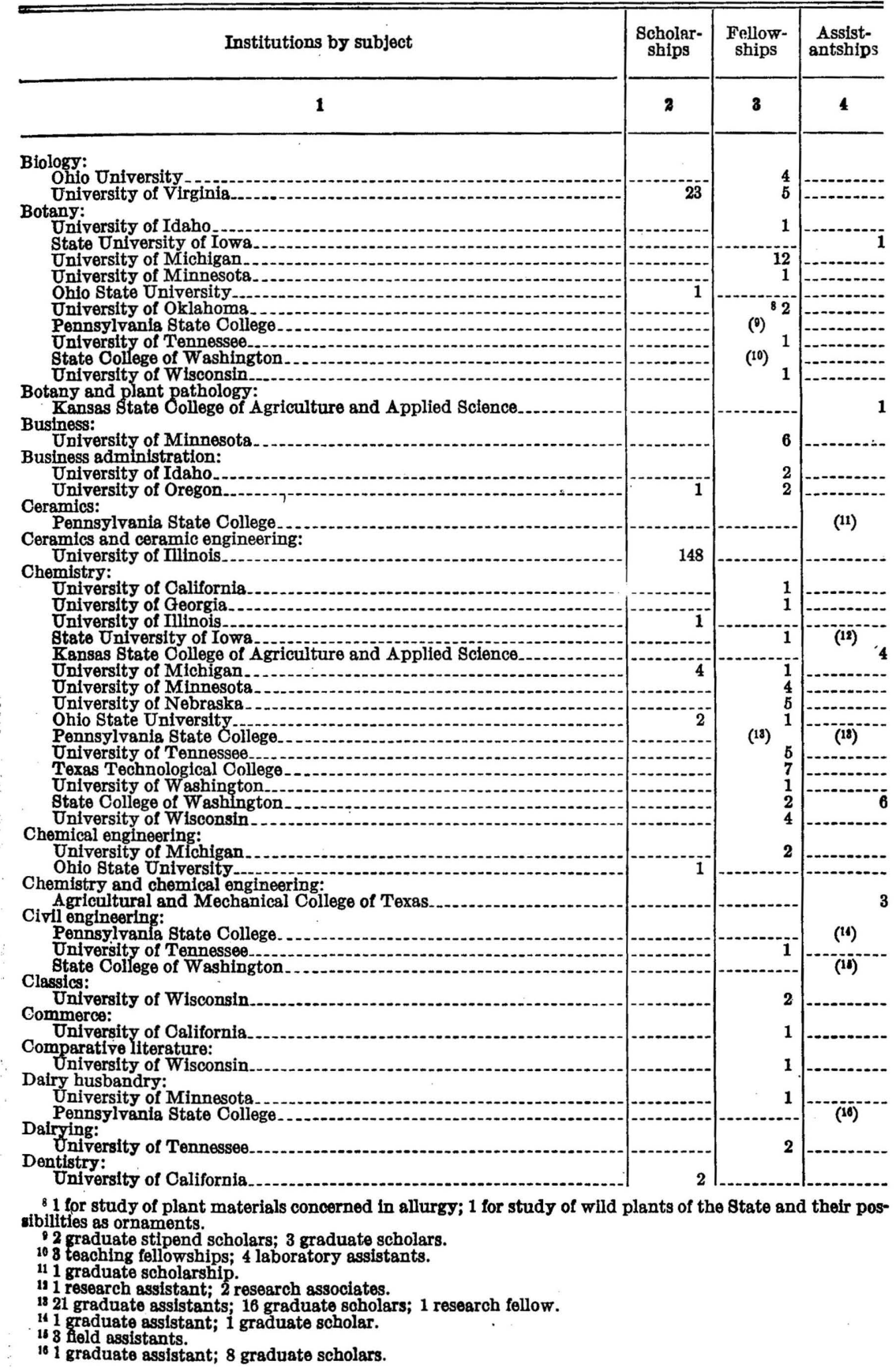


TABLII 4--SCHOLARSHIPS AND FELLOWSHIPS AT STATE-SUPPORTED UNIVERSITIES AND COLLEGES DESIGNATED FOR STUDY IN SPECIAL FIELDS-Continued

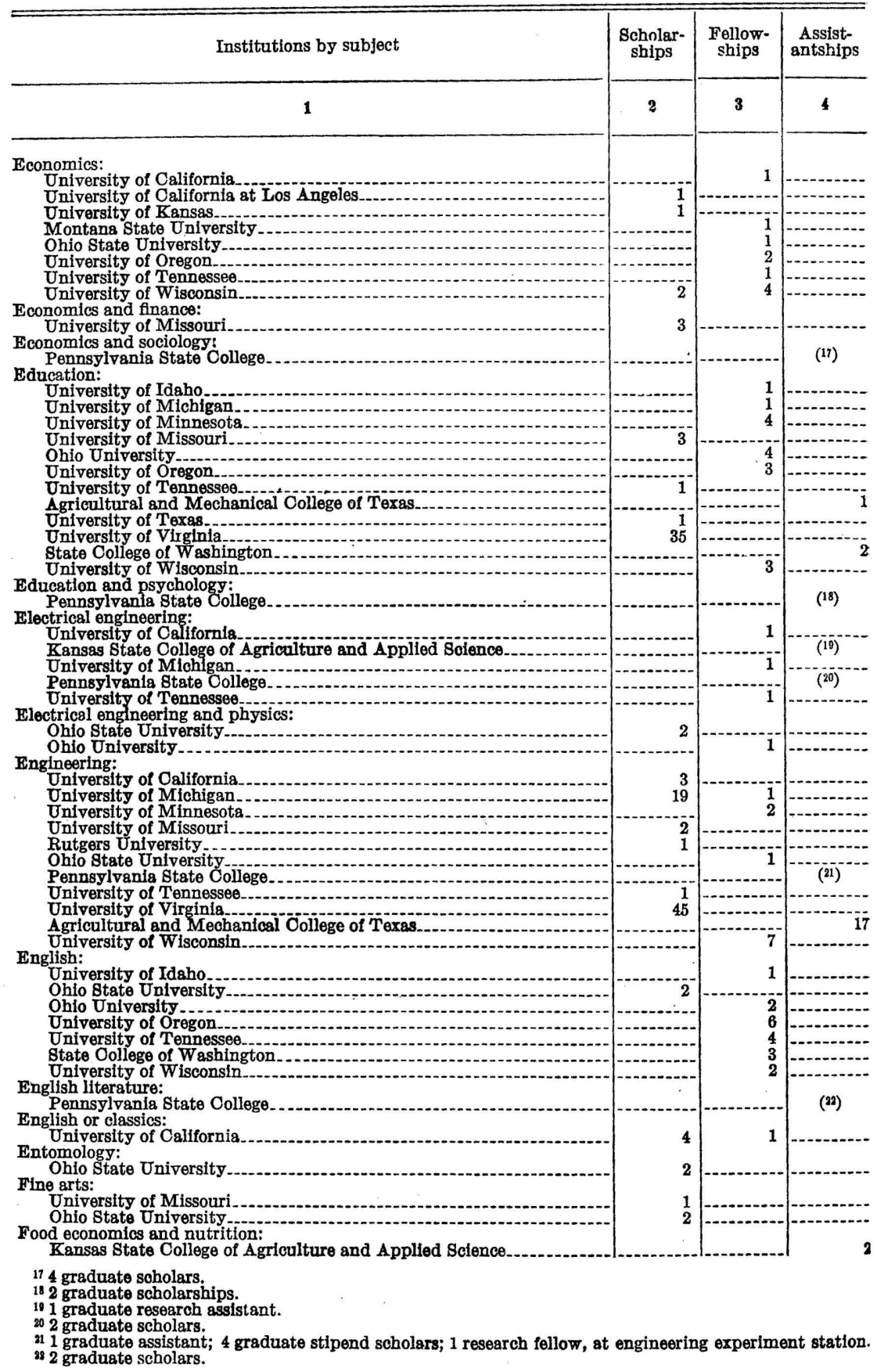


TABLE 4.-SCHOLARSHIPS AND FELLOWSHIPS AT STATE-SUPPORTED UNIVERSITIES AND COLLEGES DESIGNATED FOR STUDY IN SPECIAL FIELDS-Continued

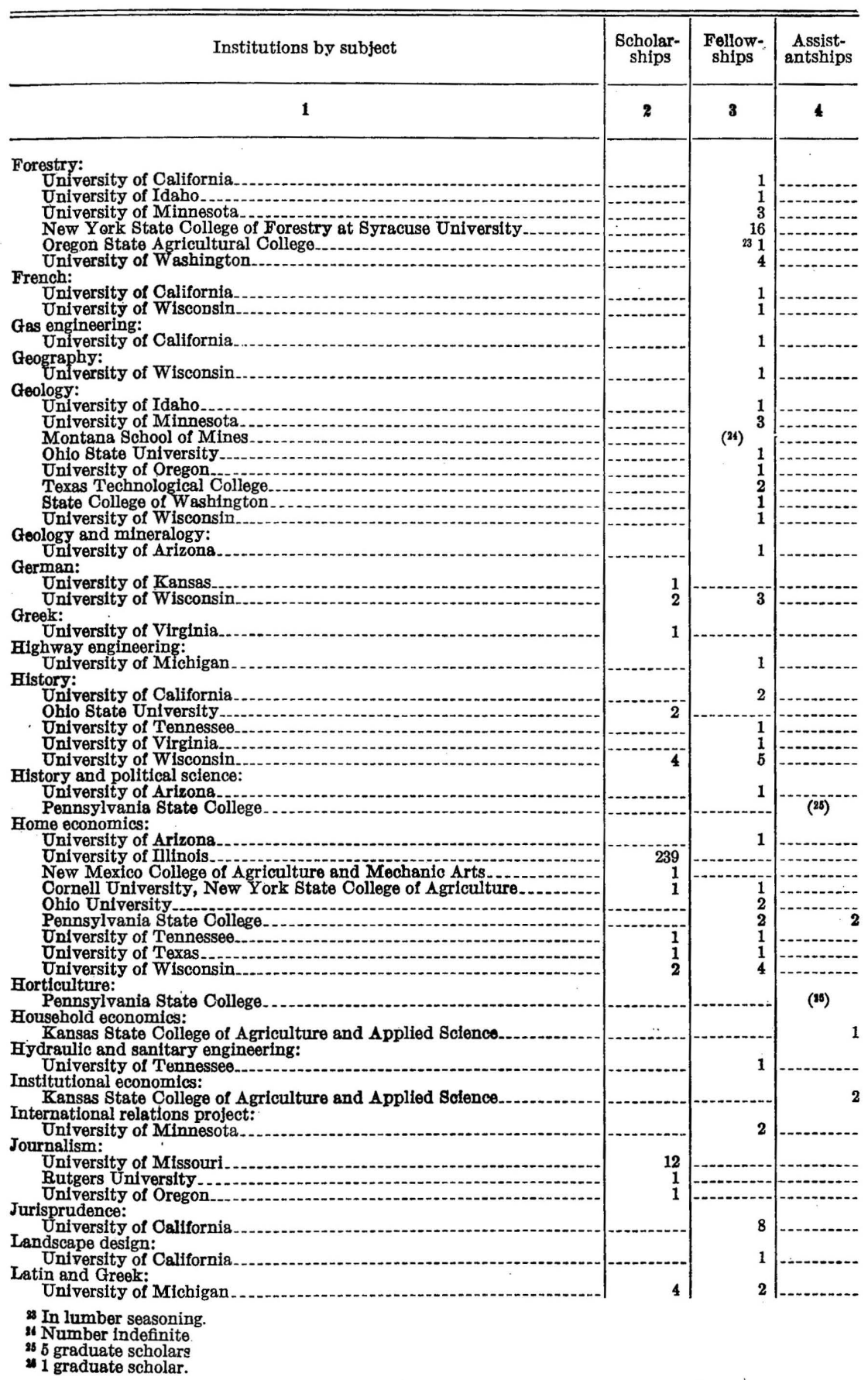


TABLE 4--SCHOLARSHIPS AND FELLOWSHIPS AT STATE-SUP-
PORTED UNIVERSITIES AND COLLEGES DESIGNATED FOR STUDY IN SPECIAL FIELDS-Continued

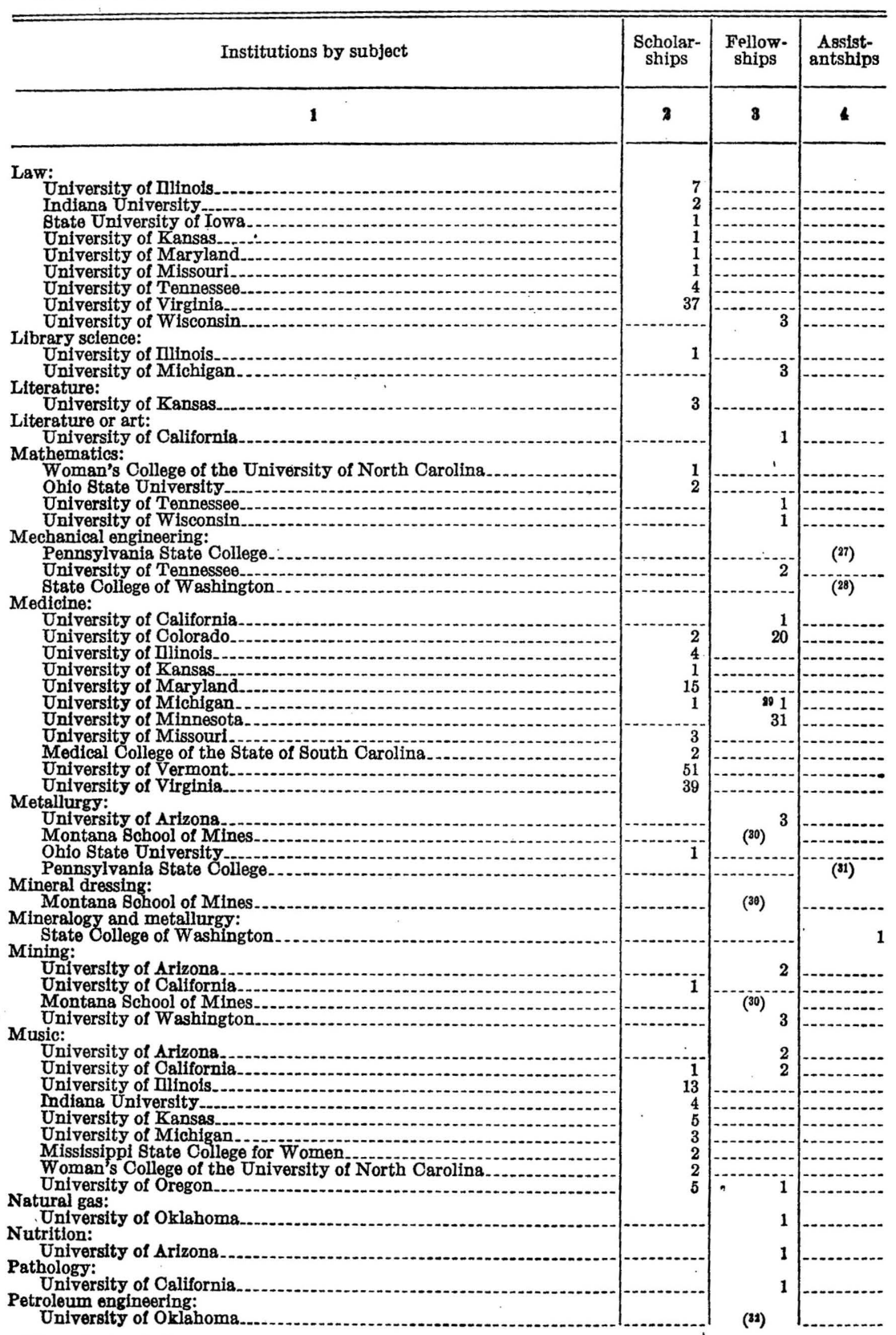

27 1 graduate scholar.

21 teaching fellowship; 1 research fellowship; 6 laboratory assistants.

3 In pharmacology.

20 Number indefinite.

in 2 graduate soholars.

a Several fellowships. 


\section{TABLI 4.-SCHOLARSHIPS AND FELLOWSHIPS AT STATE-SUP. PORTED UNIVERSITIES AND COLLEGES DESIGNATED FOR STUDY IN SPECIAL FIELDS-Continued}

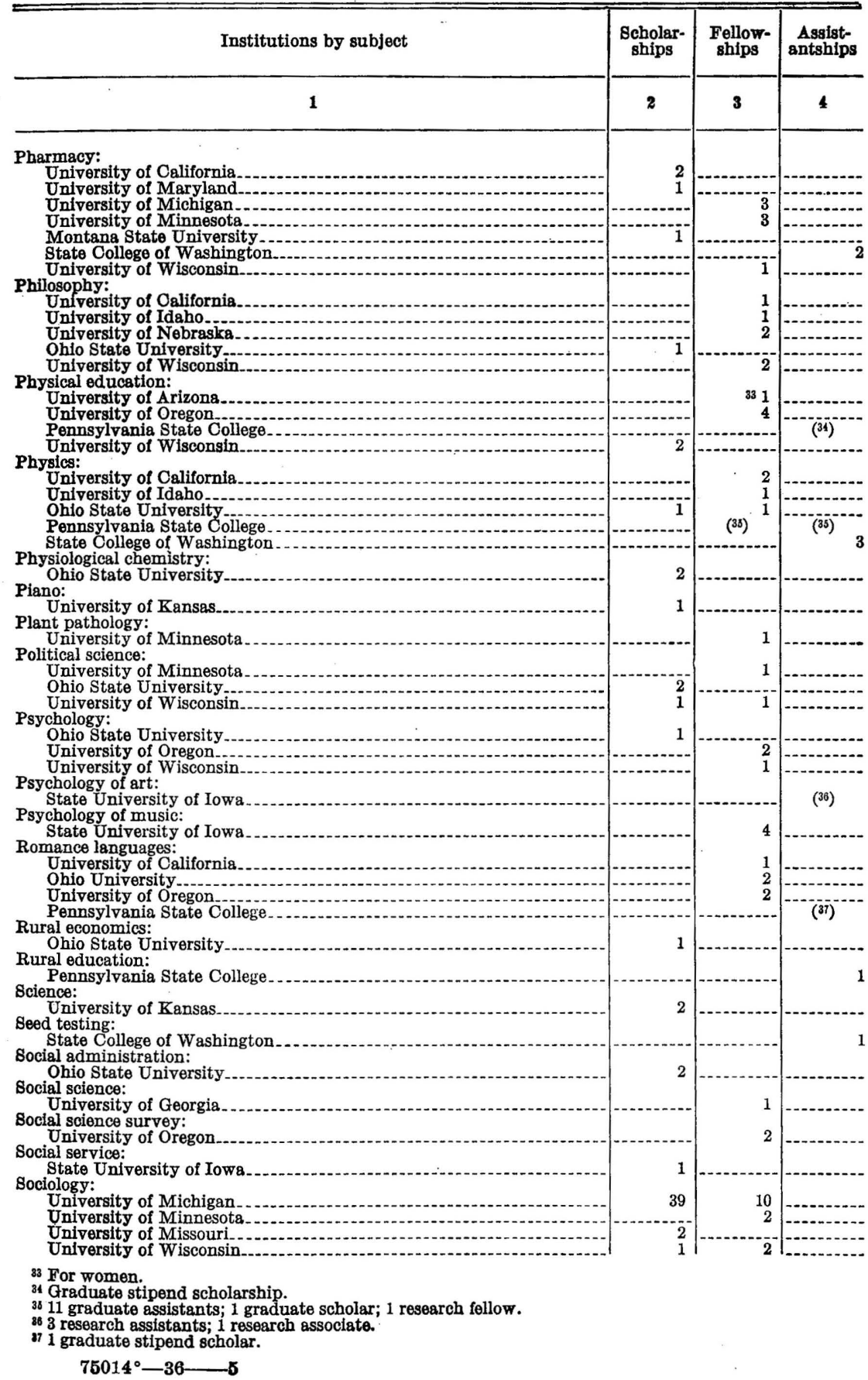


TABLE 4.-SCHOLARSHIPS AND FELLOWSHIPS AT STATE SUPPORTED UNIVERSITIES AND COLLEGES DESIGNATED FOR STUDY IN SPECIAL FIELDS-Continued

\begin{tabular}{l} 
Institutions by subject \\
\hline
\end{tabular}

3s 5 research associates.

89 1 or more fellowships for museum fleld work.

Noтв.-Some of the institutions that reported scholarships and fellowships did not give the number offered for study in special fields; others stated that they had fellowships available in many departments, without specifying them. Also a number of institutions known to offer assistantships did not report them. 
TABLE 5.-SCHOLARSHIPS AVAILABLE AT STATE-SUPPORTED TEACHERS COLLEGES AND NORMAL SCHOOLS, 1934-35

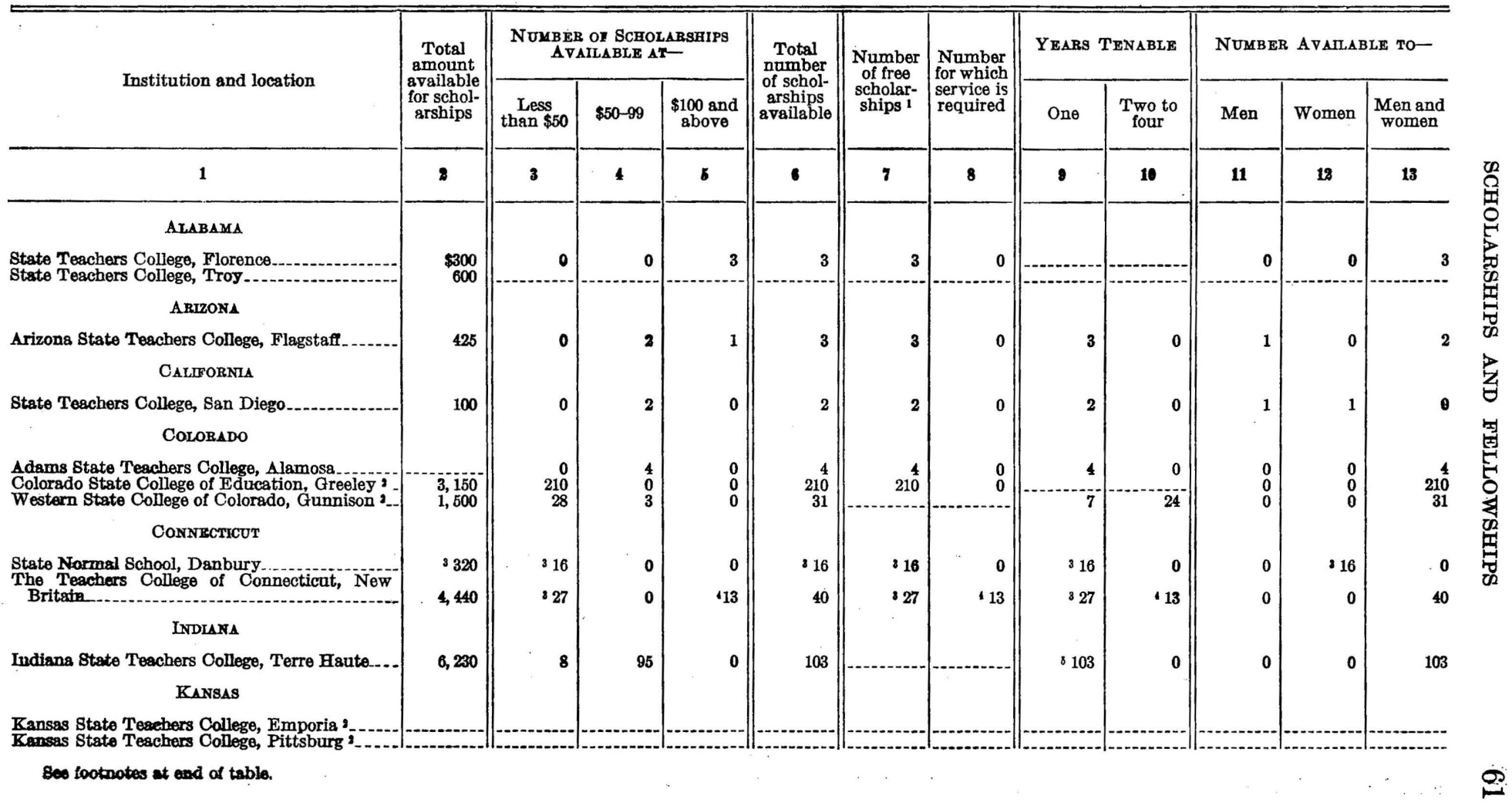



TABLE 5.-SCHOLARSHIPS AVAILABLE AT STATE-SUPPORTED TEACHERS COLLEGES AND NORMAL SCHOOLS,

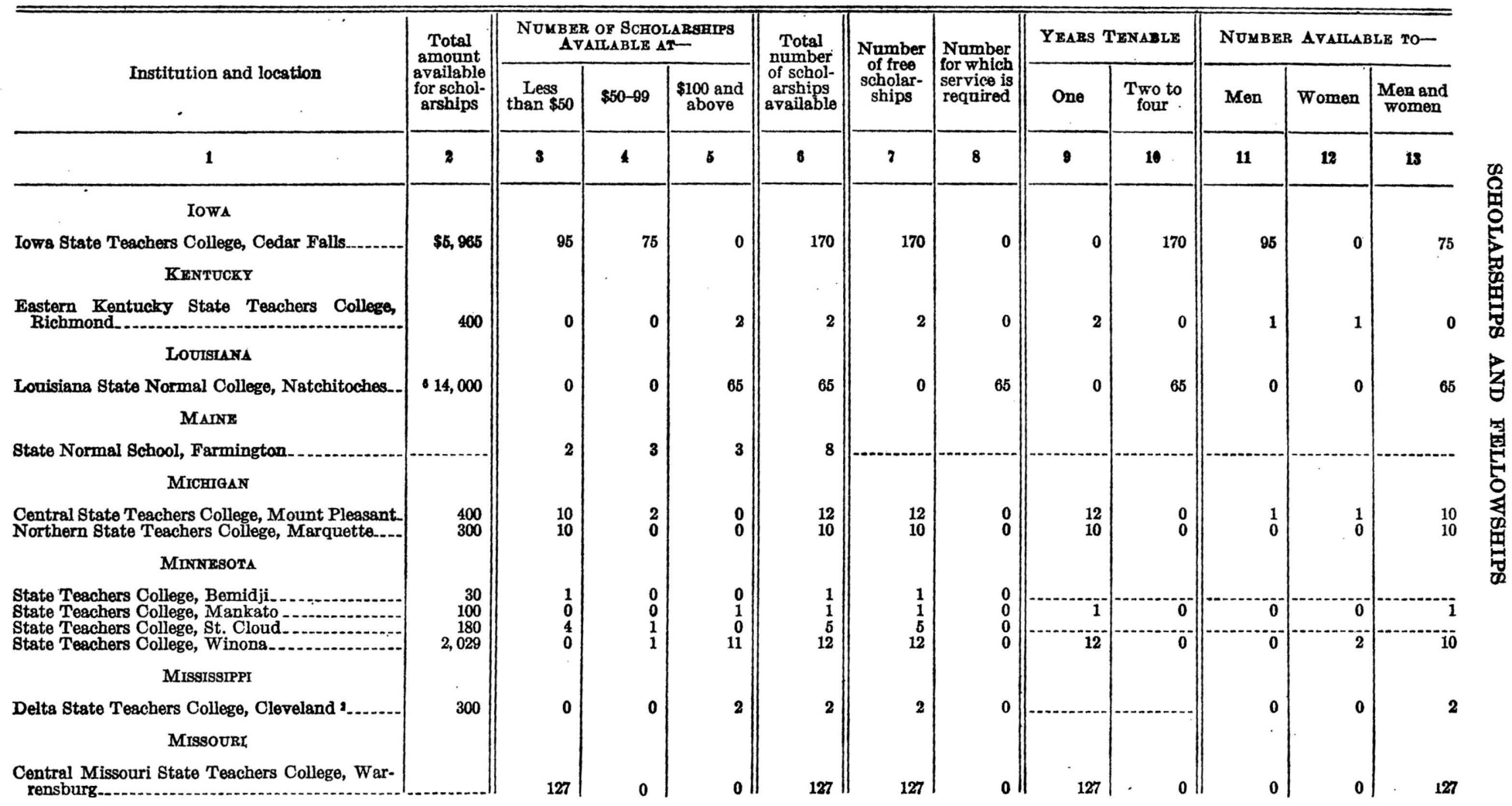


Southeast Missouri State Teachers College, Sonthwest Missouri State Teachers College,
Springfield. MONTANA

Eastern Montana Normal School, Billings. Montana State Normal College, Dillon

\section{NEBRAsKa}

Nebraska State Normal College, Chadron. Nebraska State Teachers Colleg, Kearnoy.-...

,

NrW JHRSEY

New Jersey State Normal School, Newark

Trenton.

New Mexico

NewMexico Normal University, East Las Vegas. NEW YORK

State Teachers College, Buffolo

NORTH DAKOTA

State Teachers College, Mayvill

PRnNSYLVANIA

State Teachers College, Mansfield

State Teachers College, Slippery Rock

SOVTH CAROIINA

State Colored Normal, Industrial, Agricultura and Mechanical College of South Carolina Orangebarg

SOUTH DAKota

Eastern State Normal School, Madison

Trennessex

Austin Peay Normal School Clarksville Tennessee Agricultural and Industrial State

Teachers College, Nashville

See footnotes at end of table.

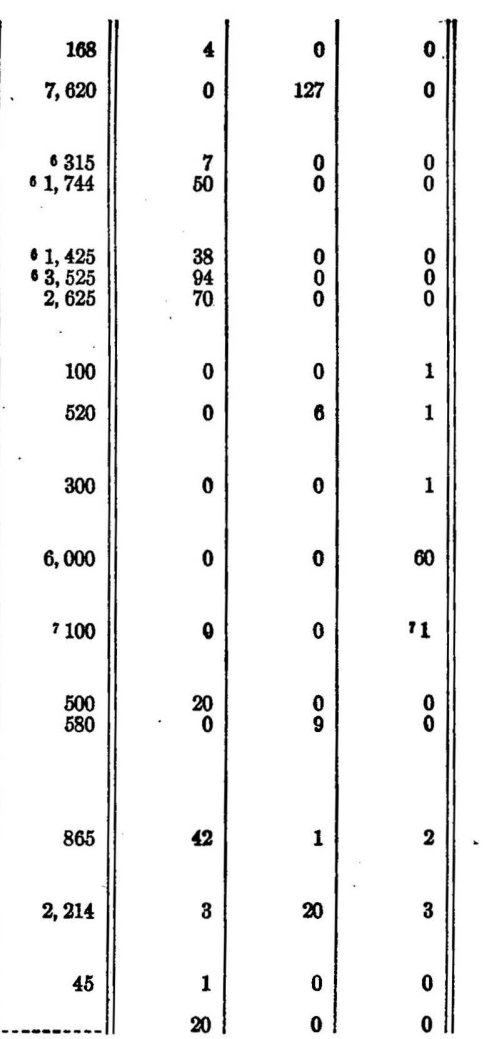

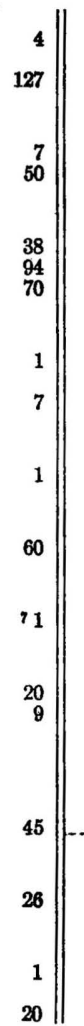

\begin{tabular}{r|}
1 \\
20
\end{tabular}

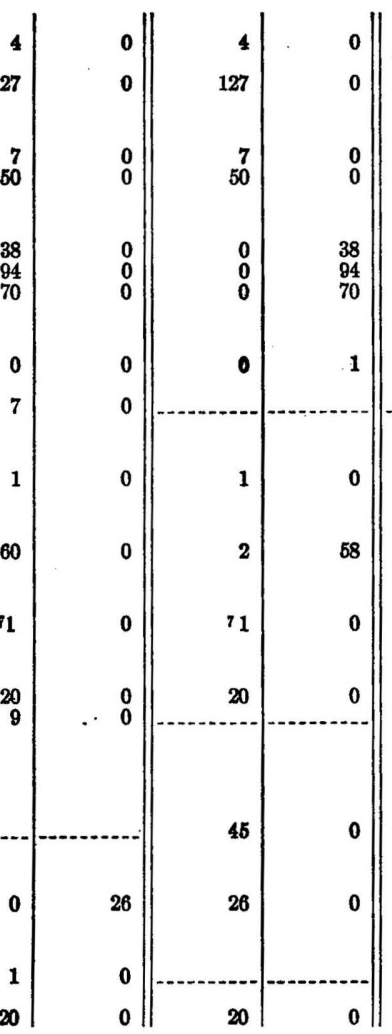

1

政

-

60

$\theta$

11

20

$\stackrel{20}{9}$

45

26

20 
TABLE 5. SCHOLARSHIPS AVAILABLE AT STATE-SUPPORTED TEACHERS COLLEGES AND NORMAL SCHOOLS, 1934-35-Continued.

\begin{tabular}{|c|c|c|c|c|c|c|c|c|c|c|c|c|}
\hline \multirow{2}{*}{ Institution and location } & \multirow{2}{*}{$\begin{array}{l}\text { Total } \\
\text { amount } \\
\text { available } \\
\text { for schol- } \\
\text { arships }\end{array}$} & \multicolumn{3}{|c|}{$\begin{array}{c}\text { NUMBER OF SCHOLARSHIPS } \\
\text { AVARABLR } \triangle T-\end{array}$} & \multirow{2}{*}{$\begin{array}{c}\text { Total } \\
\text { number } \\
\text { of schol- } \\
\text { arships } \\
\text { available }\end{array}$} & \multirow{2}{*}{$\begin{array}{c}\text { Number } \\
\text { of free } \\
\text { scholar- } \\
\text { ships }\end{array}$} & \multirow{2}{*}{$\begin{array}{l}\text { Number } \\
\text { for which } \\
\text { service is } \\
\text { required }\end{array}$} & \multicolumn{2}{|c|}{ YEARS TENABLE } & \multicolumn{3}{|c|}{ NUMBER AVAILABLE TO- } \\
\hline & & $\begin{array}{c}\text { Less } \\
\text { than } \$ 50\end{array}$ & $\$ 50-99$ & $\begin{array}{c}\$ 100 \text { and } \\
\text { above }\end{array}$ & & & & One & $\begin{array}{l}\text { Two to } \\
\text { four }\end{array}$ & Men & Women & $\begin{array}{c}\text { Men and } \\
\text { women }\end{array}$ \\
\hline 1 & 2 & 8 & 4 & 5 & 8 & $\boldsymbol{\gamma}$ & 8 & ? & 10 & 11 & 12 & 13 \\
\hline Traxas & & & & & & & & & & & & \\
\hline $\begin{array}{l}\text { ville-1 } \\
\text { Stephen } \mathrm{F} \text { Austin State Teachers Coiliege, }\end{array}$ & 500 & 10 & 0 & 0 & 10 & 10 & 0 & 10 & 0 & 0 & 0 & 10 \\
\hline $\begin{array}{l}\text { Nacogdoches } \\
\text { Southwest Texas State Teachers College, San }\end{array}$ & 1,000 & 0 & 20 & 0 & 20 & 20 & 0 & 20 & 0 & 0 & 0 & 20 \\
\hline $\begin{array}{l}\text { Maros } \\
\text { Sul Ross State Teachers Côliege, Äipine }\end{array}$ & $\begin{array}{r}1,350 \\
225\end{array}$ & $\stackrel{0}{1}$ & 27 & $\begin{array}{l}0 \\
0\end{array}$ & $\begin{array}{r}27 \\
5\end{array}$ & 27 & $\begin{array}{l}0 \\
0\end{array}$ & 27 & $\begin{array}{l}0 \\
0\end{array}$ & $\begin{array}{l}0 \\
0\end{array}$ & $\stackrel{0}{0}$ & 27 \\
\hline WASBINGTON & & & & & & & & & & & & \\
\hline Washington State Normal School, Cheney & 780 & 20 & 1 & 2 & 23 & 23 & $\mathbf{0}$ & 23 & 0 & 0 & 2 & 21 \\
\hline WIBCONSIN & & & & & & & & & & & & \\
\hline
\end{tabular}

1 Repayment not required.

These institutions granted fellowships in 1934-35 as follows:
Colorado State Teachers College -7, at total value of $\$ 2,640$; all require service, are tenable for 1 year, and are open to men and women.

Western State College of Colorado-1, at $\$ 1,500$; tenure, 1 year; open to men and women.

Cansas State Teachers College (Emporia)-6, at total value of \$1,440; all require service, are tenable for 1 year, and are open to men and women.

Delta State Teachers College-18, at total value of $\$ 2,000 ; 6$ must be repaid; 12 require service; 6 are tenable for 2 years, 12 for 1 year; all are open to men and women.

3 Remissions of tuition fees to ranking students.

State scholarships. Holders must teach in rural schools for 2 years after completion of the course.

80 may be held 4 years.

? Music scholarship.
Negro: 


\title{
PART IV: SCHOLARSHIPS AND FELLOWSHIPS AVAILABLE AT MUNICIPALLY SUPPORTED HIGHER EDUCATIONAL INSTITUTIONS, 1934-35
}

\begin{abstract}
$O^{\mathrm{F}}$ F THE 189 city-supported institutions listed in the directory of higher education for 1935, 151 were junior colleges. The remainder consisted of 12 colleges and universities, 4 professional schools, 8 teachers' colleges, and 14 normal schools. Among this number of institutions, 40 reported funds for the award of scholarships or fellowships. Ten of these were of college or university rank. Since no tuition or very low tuition is charged city residents at the municipally supported institutions, the possession of large scholarship funds by them is not so important as at institutions where tuition is high. However, the boards of trustees of several of the city colleges and universities have provided for some free scholarships in addition to those contributed from private sources.
\end{abstract}

\section{CITY SCHOLARSHIPS}

The board of regents of the University of Wichita, Wichita, Kans., offers annually a scholarship of $\$ 75$ to the $4-\mathrm{H}$ club boy or girl making the best record in general all-around 4-H leadership. The scholarship covers a year's tuition.

At the University of Louisville, Louisville, Ky., certain funds appropriated by the board of trustees are awarded to deserving students, on recommendation of the university committee on scholarships. Two teaching fellowships carrying a stipend of $\$ 250$ each are awarded on the recommendation of the faculty to graduate students in the college of liberal arts. Eight research assistantships of $\$ 135$ each are allotted annually to students in the school of medicine who distinguish themselves by their work. Preference is given to candidates for graduate degrees.

At Wayne University, the city college of Detroit, Mich., on authority of the board of education of the city a scholarship covering tuition and matriculation fees for the freshman year is granted to a member of the graduating class of each high school in Detroit. The award is based on scholarship, seriousness of purpose, ability, promise, and personality.

The University of Cincinnati, Cincinnati, Ohio, may award annually in the teachers' college, on recommendation of the dean, 12 graduate scholarships covering tuition of $\$ 200 ; 12$ graduate fellowships covering 
tuition of $\$ 200$, with a stipend of $\$ 200$ additional; and 12 graduate assistantships covering tuition, with a stipend of $\$ 500$ additional. Recipients of these offerings are required to render service to the college.

The University of Toledo, Toledo, Ohio, grants 15 scholarships to freshman students on recommendations from the high-school principals of Toledo. The university also awards about 100 "service scholarships" each year to unusually competent students who assist the faculty in the various departments.

By authority of the board of trustees of the College of Charleston, Charleston, S. C., the probate judge and the superintendent of education of each county of South Carolina may jointly appoint annually one student, resident of the county, to a free tuition scholarship covering the length of the college course.

In two cities at least the city government appropriates funds for the support of scholarships at privately endowed institutions. The city of New Orleans has authorized the mayor to select and appoint annually five students from among the deserving poor and needy boys or girls attending the public schools of the city to scholarships at Tulane University, in the college of arts and sciences (except the premedical course), the college of engineering, or Sophie Newcomb College. The scholarships confer the privilege of free tuition and exemption from the registration fee, and are tenable for the full college course. 
TABLE 6. -SCHOLARSHIPS AVAILABLE AT MONICTPALLY SUPPORTED COLLEGES AND UNIVERSITIES, 1934-35

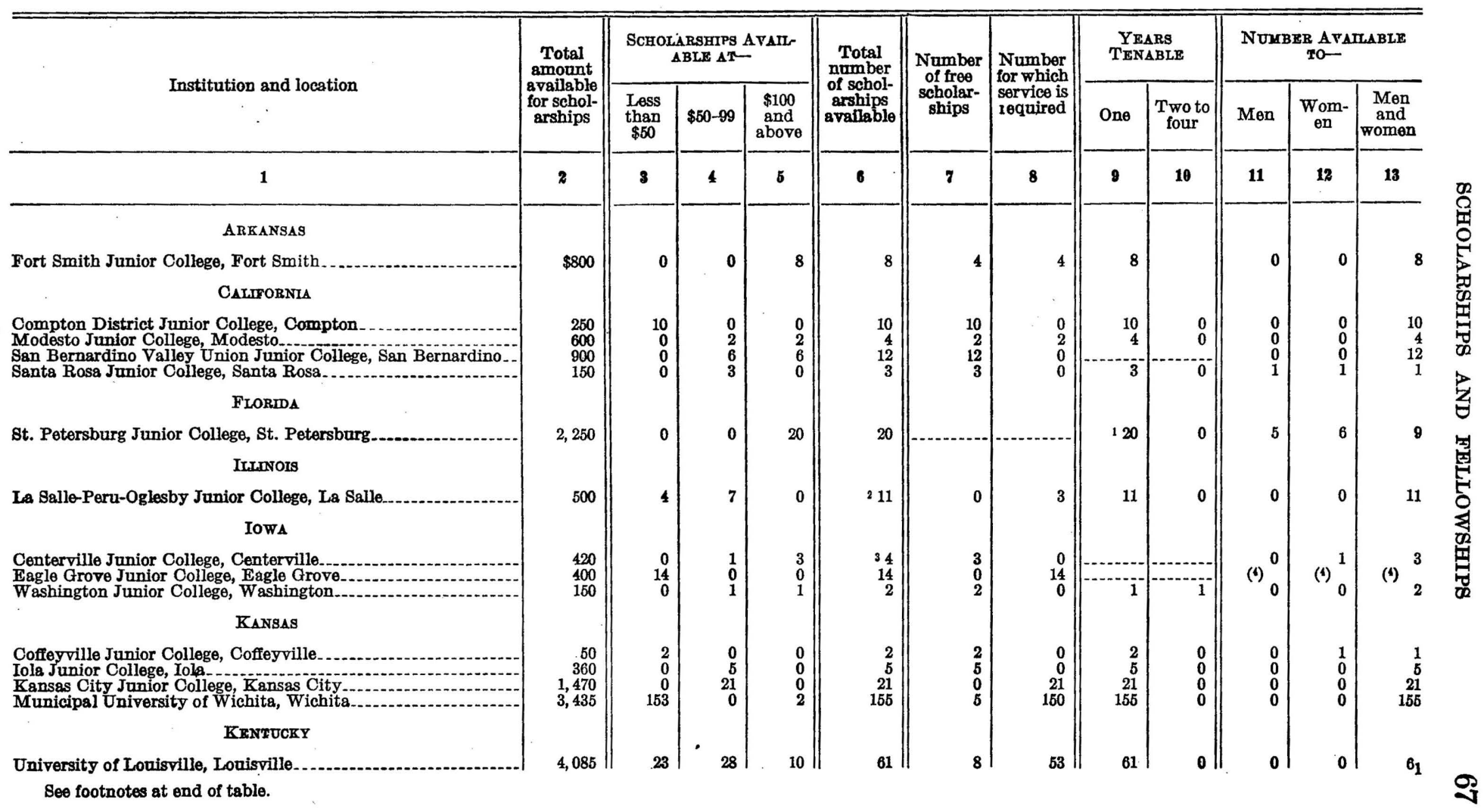


TABLE 6.-SCHOLARSHIPS AVAILABLE AT MUNICIPALLY SUPPORTED COLLEGES AND UNIVERSITIES, 1934-35-Con.

\begin{tabular}{|c|c|c|c|c|c|c|c|c|c|c|c|c|}
\hline \multirow{2}{*}{ Institution and location } & \multirow{2}{*}{$\begin{array}{c}\text { Total } \\
\text { amount } \\
\text { available } \\
\text { for schol- } \\
\text { arships }\end{array}$} & \multicolumn{3}{|c|}{ 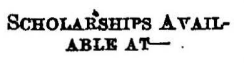 } & \multirow{2}{*}{$\begin{array}{c}\text { Total } \\
\text { number } \\
\text { of schol- } \\
\text { arships } \\
\text { available }\end{array}$} & \multirow{2}{*}{\begin{tabular}{|} 
Number \\
of free \\
scholar- \\
ships
\end{tabular}} & \multirow{2}{*}{$\begin{array}{l}\text { Number } \\
\text { for which } \\
\text { service is } \\
\text { required }\end{array}$} & \multicolumn{2}{|c|}{$\underset{\text { TERABLE }}{\text { YEARS }}$} & \multicolumn{3}{|c|}{$\underset{\text { NO- }}{\text { NUMBRR ATATABLE }}$} \\
\hline & & $\begin{array}{l}\text { Less } \\
\text { than } \\
\$ 50\end{array}$ & $\$ 50-99$ & $\begin{array}{l}\$ 100 \\
\text { and } \\
\text { above }\end{array}$ & & & & One & \begin{tabular}{|c|c|} 
Two to \\
four
\end{tabular} & Men & $\begin{array}{c}\text { Wom- } \\
\text { en }\end{array}$ & \begin{tabular}{|c|} 
Men \\
and \\
women
\end{tabular} \\
\hline 1 & 2 & 3 & 4 & 5 & 6 & 7 & 8 & 9 & 10 & 11 & 12 & 13 \\
\hline 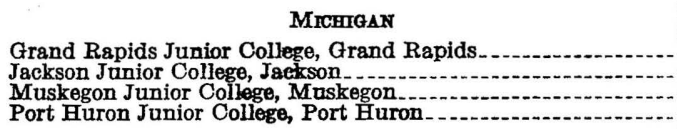 & $\begin{array}{l}\$ \$ \$ 30 \\
130 \\
150 \\
180\end{array}$ & $\begin{array}{l}0 \\
0 \\
0 \\
0\end{array}$ & $\begin{array}{l}3 \\
2 \\
3 \\
3 \\
3\end{array}$ & $\begin{array}{r}14 \\
0 \\
0 \\
0\end{array}$ & $\begin{array}{r}17 \\
2 \\
3 \\
3\end{array}$ & $\begin{array}{r}17 \\
2 \\
3 \\
3\end{array}$ & $\begin{array}{l}0 \\
0 \\
0 \\
0\end{array}$ & $\begin{array}{l}-2 \\
3 \\
3\end{array}$ & $\begin{array}{r}-0 \\
0 \\
0 \\
0\end{array}$ & $\begin{aligned} &(4) 0 \\
& 0 \\
& 1\end{aligned}$ & (t) $\begin{array}{r}2 \\
3 \\
1 \\
1\end{array}$ & (4) $\begin{array}{l}0 \\
0 \\
1\end{array}$ \\
\hline $\begin{array}{l}\text { MINNEsots } \\
\text { Itasca Junior College, Coleraine- } \\
\text { Rochester Junior College, Rochester.... }\end{array}$ & $\begin{array}{l}(6) \\
(6)\end{array}$ & $\begin{array}{r}10 \\
4\end{array}$ & $\stackrel{0}{3}$ & ${ }_{2}^{0}$ & $\begin{array}{r}10 \\
9\end{array}$ & 10 & 0 & $\begin{array}{l}1 \\
9\end{array}$ & $\begin{array}{l}9 \\
0\end{array}$ & $\begin{array}{l}0 \\
0\end{array}$ & $\begin{array}{l}0 \\
0\end{array}$ & $\begin{array}{r}10 \\
8\end{array}$ \\
\hline $\begin{array}{c}\text { MrssouRI } \\
\text { Jefferson City Junior College, Jefferson City.. }\end{array}$ & 40 & 1 & 0 & 0 & 1 & 1 & 0 & 1 & 0 & 0 & 0 & : \\
\hline NEBRASKA & & & & & & & & & & & & \\
\hline $\begin{array}{l}\text { McCook Junior College, McCook } \\
\text { Municipal University of Omaha, Omaha } \\
\text { Scottsbluff Junior College, Scottshluff }\end{array}$ & $\begin{array}{r}280 \\
5,940 \\
490\end{array}$ & $\begin{array}{r}14 \\
0 \\
0\end{array}$ & $\begin{array}{l}0 \\
\frac{1}{7}\end{array}$ & $\begin{array}{r}0 \\
48 \\
0\end{array}$ & $\begin{array}{r}14 \\
49 \\
7\end{array}$ & ${ }^{(7)}{ }_{7}^{14}$ & $\begin{array}{l}0 \\
1 \\
0\end{array}$ & $\begin{array}{r}0 \\
27\end{array}$ & $\begin{array}{l}14 \\
22\end{array}$ & $\begin{array}{l}0 \\
0 \\
0\end{array}$ & $\begin{array}{l}0 \\
1 \\
0\end{array}$ & $\begin{array}{r}14 \\
48 \\
7\end{array}$ \\
\hline $\begin{array}{l}\text { NEW YORK } \\
\text { Brooklyn College, Brooklyn }\end{array}$ & ' 17,890 & 3 & 0 & $\cdot 158$ & 161 & 161 & 0 & 3 & 158 & 0 & 0 & 161 \\
\hline College of the City of New York, New York.. & & 0 & 0 & 1003 & 645 & 645 & 0 & & $\cdots$ & (`) & (4) & (๑) \\
\hline Hunter College, New York & 11,193 & 1 & 3 & 4 & 128 & ${ }^{18} 7$ & 0 & 8 & 0 & 0 & 8 & 0 \\
\hline $\begin{array}{l}\text { University of Akron, Akron } \\
\text { University of Cincinnati, Cincinnati } \\
\text { University of Toledo, Toledo }\end{array}$ & $\begin{array}{l}2,400 \\
8,250 \\
8,635\end{array}$ & $\begin{array}{r}18 \\
47 \\
243\end{array}$ & $\begin{array}{r}8 \\
26 \\
0\end{array}$ & $\begin{array}{r}0 \\
28 \\
0\end{array}$ & $\begin{array}{r}26 \\
101 \\
243\end{array}$ & $\begin{array}{l}18 \\
92 \\
58\end{array}$ & $\begin{array}{r}8 \\
0 \\
185\end{array}$ & $\begin{array}{r}26 \\
101\end{array}$ & $\begin{array}{l}0 \\
0\end{array}$ & ${ }_{(4)}^{10}$ & $(4)^{0}$ & (4) $^{25}$ \\
\hline $\begin{array}{r}\text { OKLAHOMA } \\
\text { tus Junior Colloge, Altus............ }\end{array}$ & 60 & 2 & 0 & 0 & 2 & 2 & 0 & & & 0 & 0 & 2 \\
\hline $\begin{array}{l}\text { SOUTH CAROLINA } \\
\text { College of Charleston, Charleston }\end{array}$ & $4,315 \|$ & 48 & 3 & 19 & 70 & 70 & 0 & 0 & 70 & 3 & 2 & 65 \\
\hline
\end{tabular}




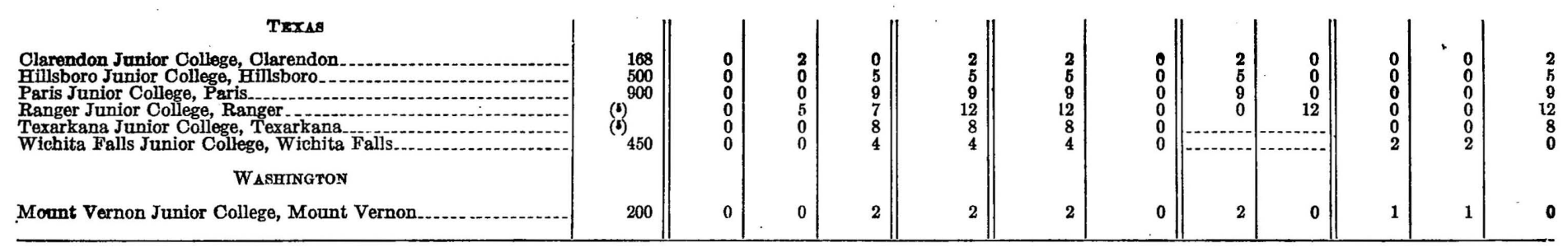

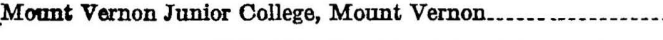

1 May be renewed.

28 of these must be repaid.

1 must be repaid.

orted.

- Free tuition to high-school graduates of the county who rank as valedictorians; 132 tuition to salutatorians. To students ranking as above, outside of the county, $1 / 2$ the amount

in each case is allowed. $7 \$ 4,690$ in free scholarships; $\$ 1,250$ in loan scholarships.

'State scholarships, carrying $\$ 100$ \& year. Students may use the scholarships in any approved higher edueational institution in the State. See p. 14.

the

12 The State scholarships used at the college were not reported.

13 is a loan scholarship.

TABLE 7.-FELLOWSHIPS AVAIIABLE AT MUNICIPALLY SUPPORTED GOLLEGES AND UNIVERSITIES, 1934-35

\begin{tabular}{|c|c|c|c|c|c|c|c|c|c|c|c|c|c|c|c|}
\hline \multirow{2}{*}{ Institution } & \multirow{2}{*}{$\begin{array}{l}\text { Total } \\
\text { amoumt } \\
\text { available } \\
\text { for fel- } \\
\text { lowships }\end{array}$} & \multicolumn{6}{|c|}{ NUMBER OF FELLOWSHIPS A VAILABLE } & \multirow{2}{*}{$\begin{array}{c}\text { Total } \\
\text { number } \\
\text { of fel- } \\
\text { low- } \\
\text { ships } \\
\text { avail- } \\
\text { able }\end{array}$} & \multirow{2}{*}{$\begin{array}{l}\text { Num- } \\
\text { ber of } \\
\text { free } \\
\text { fellow- } \\
\text { ships }\end{array}$} & \multirow{2}{*}{$\begin{array}{l}\text { Num- } \\
\text { ber for } \\
\text { which } \\
\text { service } \\
\text { is re- } \\
\text { quired }\end{array}$} & \multicolumn{2}{|c|}{$\underset{\text { TERABLE }}{\text { YEARS }}$} & \multicolumn{3}{|c|}{$\begin{array}{l}\text { NUMBER AVATLABLI } \\
\text { TO- }\end{array}$} \\
\hline & & $\mid \begin{array}{c}\$ 299 \\
\text { or less }\end{array}$ & $\$ 300-$ & $\$ 400-$ & $\$ 500-$ & \begin{tabular}{|}
$\$ 750-$ \\
$\$ 999$
\end{tabular} & $\begin{array}{l}\$ 1,000 \\
\text { and } \\
\text { over }\end{array}$ & & & & One & $\begin{array}{c}\text { Two } \\
\text { or } \\
\text { more }\end{array}$ & Men & Women & $\begin{array}{c}\text { Men } \\
\text { and } \\
\text { women }\end{array}$ \\
\hline 1 & 2 & 3 & 4 & 5 & 6 & 7 & 8 & 9 & 10 & 11 & 12 & 13 & 14 & 15 & 16 \\
\hline $\begin{array}{l}\text { University of Louisville- } \\
\text { Municipal University of Omaha } \\
\text { Hunter College } \\
\text { University of Akron, Akron } \\
\text { University of Cincinnati- } \\
\text { College of Charleston }\end{array}$ & $\begin{array}{r}\$ 1,580 \\
43 \\
720 \\
750 \\
29,630 \\
100\end{array}$ & \begin{tabular}{r|}
10 \\
1 \\
1 \\
0 \\
6 \\
1
\end{tabular} & $\begin{array}{l}0 \\
0 \\
0 \\
0 \\
7 \\
0\end{array}$ & $\begin{array}{l}0 \\
0 \\
1 \\
0 \\
3 \\
0\end{array}$ & $\begin{array}{r}0 \\
0 \\
0 \\
0 \\
12 \\
0\end{array}$ & $\begin{array}{l}0 \\
0 \\
0 \\
1 \\
1 \\
0\end{array}$ & $\begin{array}{r}0 \\
0 \\
0 \\
0 \\
16 \\
0\end{array}$ & \begin{tabular}{r|r}
10 & \\
1 & 2 \\
1 & 45 \\
1 &
\end{tabular} & $\begin{array}{r}0 \\
0 \\
2 \\
1 \\
32 \\
0\end{array}$ & $\begin{array}{r}10 \\
1 \\
0 \\
0 \\
13 \\
1\end{array}$ & $\begin{array}{r}10 \\
25 \\
1 \\
15\end{array}$ & \begin{tabular}{c}
0 \\
\hdashline 0 \\
\hdashline 0 \\
0
\end{tabular} & $\begin{array}{r}0 \\
0 \\
1 \\
11 \\
1\end{array}$ & $\begin{array}{c}0 \\
-2 \\
0 \\
2 \\
0\end{array}$ & $\begin{array}{r}10 \\
-0 \\
0 \\
32 \\
0\end{array}$ \\
\hline
\end{tabular}


Scholarships and fellowships in the following special fields are offered by the institutions listed in the preceding tables. The number of offerings in special fields are included in the figures given in the tables.

TABLE 8.-SCHOLARSHIPS AND FELLOWSHIPS AT MUNICIPALLY SUPPORTED UNIVERSITIES AND COLLEGES DESIGNATED FOR STUDY IN SPECIAL FIELDS

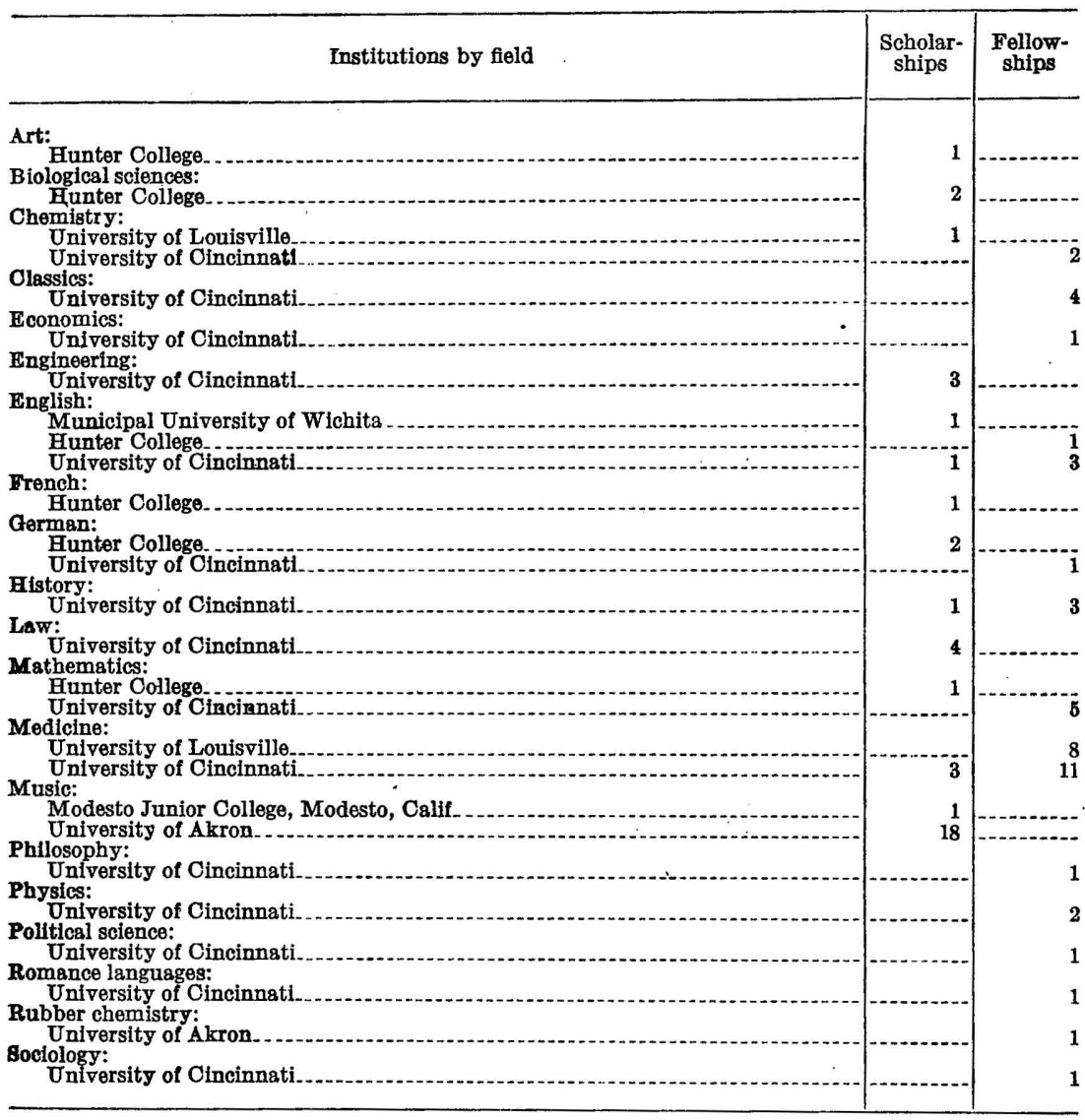




\section{PART V: SCHOLARSHIPS AND FELLOWSHIPS AVAILABLE AT PRIVATELY ENDOWED INSTITUTIONS, 1934-35}

$\mathrm{S}$ CHOLARSHIP FUNDS given through private philanthropy at many of the endowed and also State-supported institutions equal or surpass in value those available through State provision. Student aid through State appropriation, however, is dependable, whereas that from private sources fluctuates with changing financial conditions. In recent years, for example, some of the private scholarship funds have declined to the point where it has been necessary to suspend the award of the scholarships or fellowships for which they make provision. This is especially true of funds of considerable size. However, although no figures are available to show definitely the effect of the years of depression on the amount of scholarship aid offered from private funds, such evidence as is at hand indicates that the total amount of this form of student aid has suffered no very great reduction.

The scholarships offered through privately contributed funds and those established by the privately supported institutions themselves tend to carry higher money values than those given from State funds; that is, there are more scholarships in the higher ranges of values. These higher values, however, are offset by the smaller tuition charges, and in the case of State students no tuition charges, made by many of the State-supported institutions.

Many of the scholarships and fellowships on private foundation are single offerings and are awarded upon conditions specified by their donors, such as scholarship standing, field of concentration, character, health, leadership and promise, participation in student activities, religious affiliation, residence in certain localities and many others. The great number of offerings and the extent of the conditions for their award render individual mention of them impracticable.

In the following tables the scholarships and fellowships offered at a large number of privately supported institutions of higher learning in 1934-35 are enumerated according (1) to value, (2) to whether they are free or must be repaid or require service to the institution, (3) to the number of years tenable, and (4) to whether they are limited to men or to women or are available to both. The total amounts of the scholarship and fellowship funds of each institution are also given. The institutions are divided into $(a)$ colleges and universities, (b) independent technical and professional schools, and (c) teachers colleges and normal schools. 


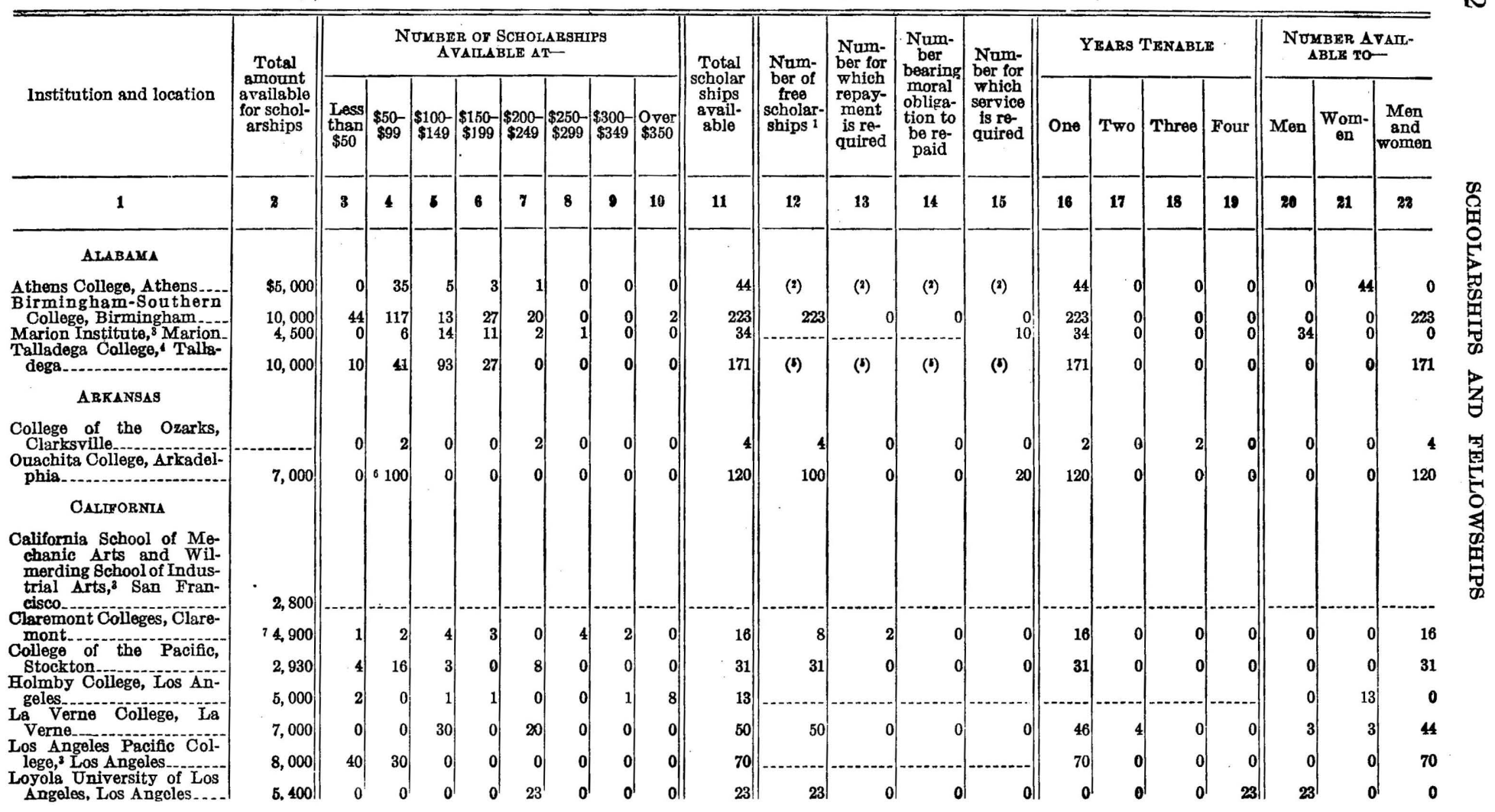




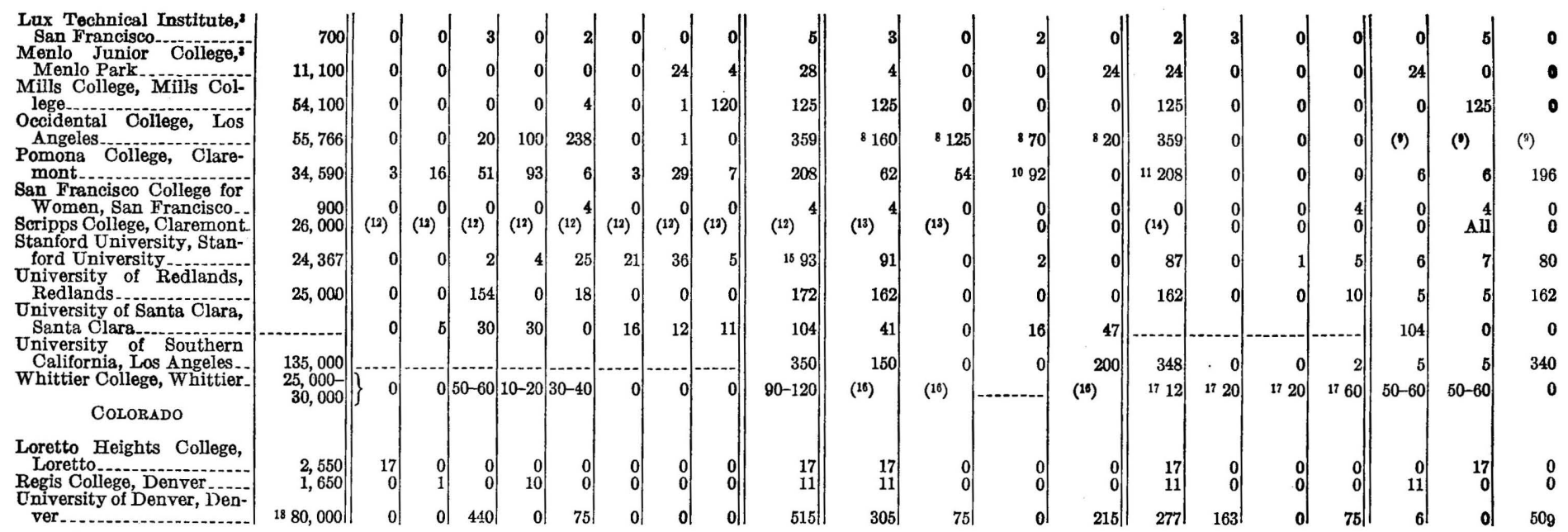

ver.

1 Repayment not required.

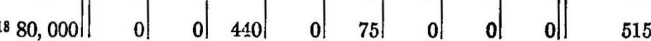

305

0

2 Of the $\$ 5,000$ available for scholarsh
orships for which service is required.

3 Junior college.

Negro. $\$ 10,000$ a vailable, the college reported $\$ 2,000$ used for free scholarships, $\$ 2,000$ for scholarships carrying a definite obligation to be repaid, the remainder carrying a mora obligation to be repaid.

For valedictorian and ministerial students.

7 Includes funds for three fellowships.

the total of these figures slightly exceeds the total number of students aided.

10 Grants in aid. Moral obligation to be repaid if the student withdraws before graduation. Service to institution may be required.

1212 regularly established and designated scholarships of $\$ 400-\$ 500$ each, granted each year. Remainder of fund-approximately $\$ 20,000-$ is available annually for grants in form

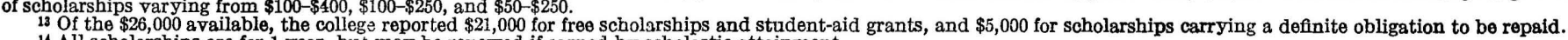

14 All scholarships are for 1 year, but may be renewed if earned by scholastic attainment.

15 Includes only scholarships awarded by the university on e competitive basit.

16 Of the $\$ 25,000-\$ 30,000$ available, $\$ 7,500$ is for free scholarships, $\$ 10,000$ for scholarships carrying a definite obligation to be repaid, and $\$ 8,000$ for scholarships for which service is required.

17 Approximately. 
TABLE 9. SCHOLARSHIPS AVAILABLE AT PRIVATELY SUPPORTED UNIVERSTTIES AND COLLEGES, 1934-35-Contd.

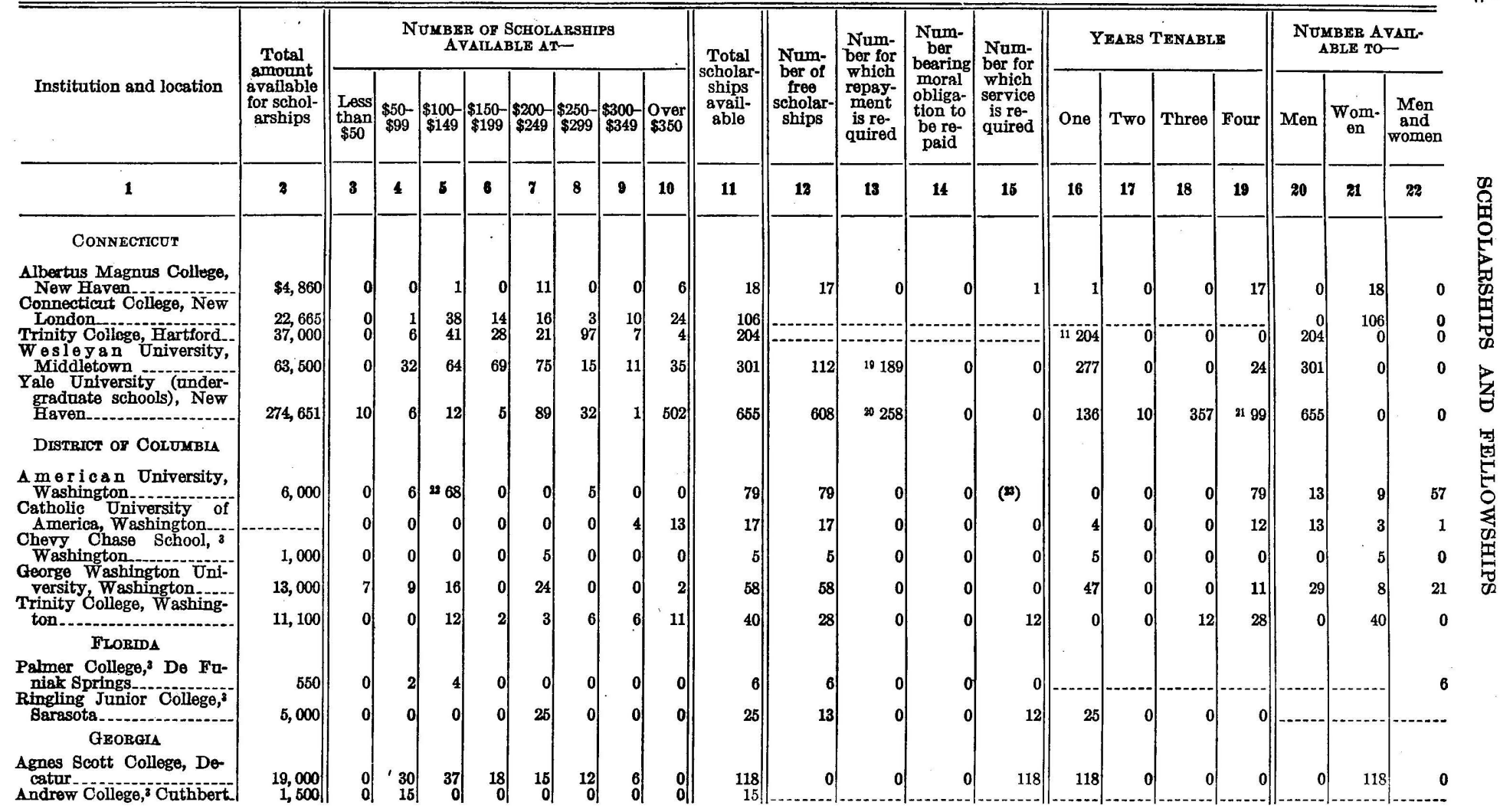




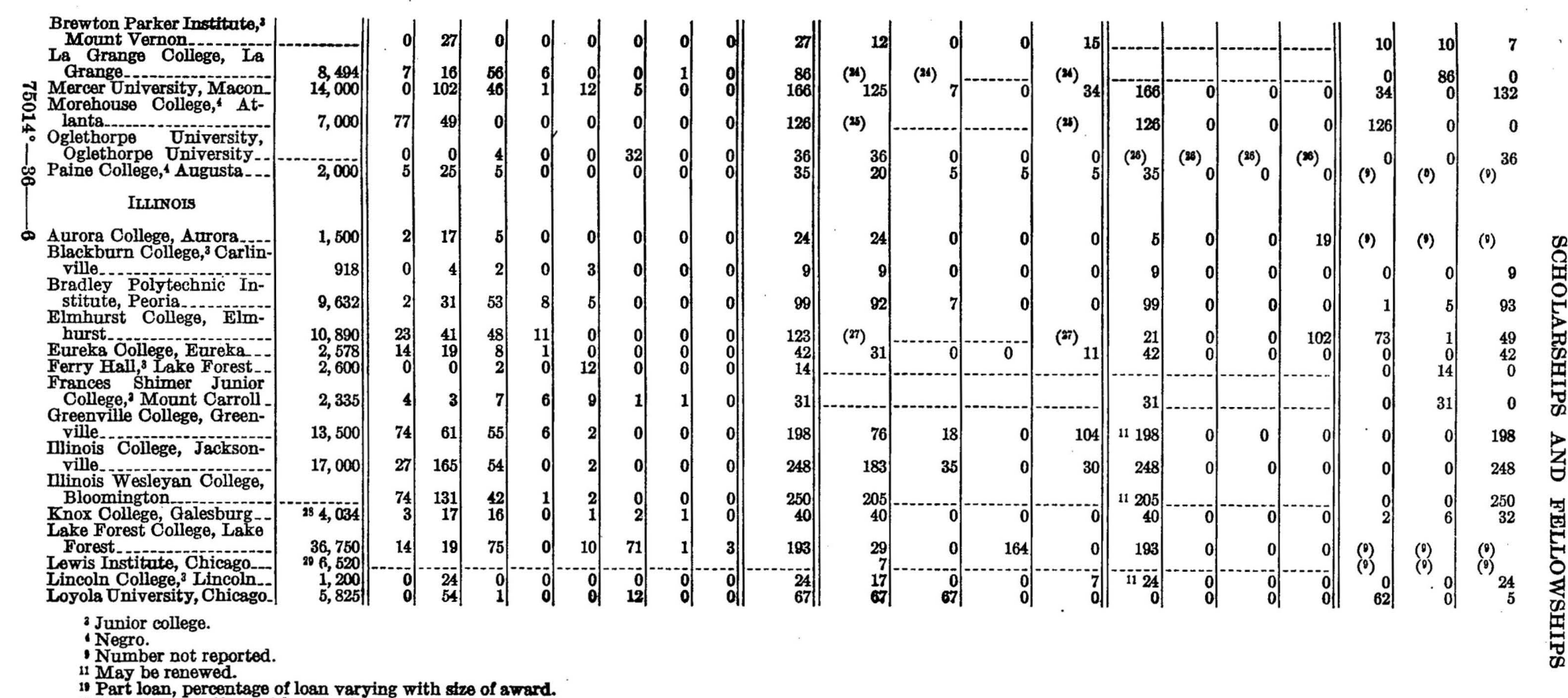

13 Part loan, percentage of loan varying with stze of award.

20211 on a part-gift, part-loan basis.

2248 are foundational scholarships, one for each State. Of these only 15 or 20 are awarded in any one year.

${ }_{23}$ Required "in some cases."

25 Free scholarships to the amount of $\$ 5,500$; service scholarships, $\$ 1,500$.

${ }_{27}$ Depending upon scholarship.

Covers scholarships for which definite provision is made annually. The college in recent years has supplomented this amount.

Wor 
TABLE 9.-SCHOLARSHIPS AVAILABLE AT PRIVATELY SUPPORTED UNIVERSTTIES AND COLLEGES, 1934-35-Contd.

Institution and location

$\frac{1}{1}$

ILInrors-Continued McKendree College, LebNorth Contral College, North Park College.3 Chicago a Northwestern Üniversity, Quincy College, Q Quincy--
Rockford College, RockSt. Procopius College, LisieSt. Viator College, Bourbonnais University of Chicago, Wheaton College, wheaton INDLANA

Butler University, IndianDe Pauw University, Greencastlo
Evansville College, Evansville Franklin College, Franklin Goshen College, Goshen Hakover College, Hanover Kokomo Marion College, Marion land City
St. Mary's College, Notre
Dame

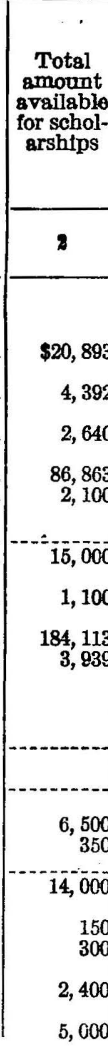

5,000

\begin{tabular}{r} 
Total \\
schola \\
ship \\
aval \\
ablo \\
\hline 11 \\
\hline 1 \\
\end{tabular}

\section{Nonratr of SchotheshTrs}

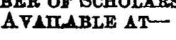

Loss $\$ \$ 50-\$ 100-\$ 150-\$ 200-\$ 250-\$ 300-$ Over

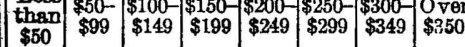

\begin{tabular}{lllllll}
\hline 3 & 5 & 6 & 7 & 8 & 9 & 10
\end{tabular}

Num-
ber of
free
scholar-
ships

\begin{tabular}{|c|c|c|c|c|}
\hline $\begin{array}{l}\text { Num- } \\
\text { ber for }\end{array}$ & Num- & Num- & Years Temable & $\begin{array}{c}\text { NUMBER } \triangle V A T- \\
\text { ABLE TO- }\end{array}$ \\
\hline & $\mid \begin{array}{l}\text { Dearmg } \\
\text { moral }\end{array}$ & $\begin{array}{l}\text { Der lor } \\
\text { which }\end{array}$ & & \\
\hline
\end{tabular}
OMBER AVAT
ABLE TO-

(1)

1112

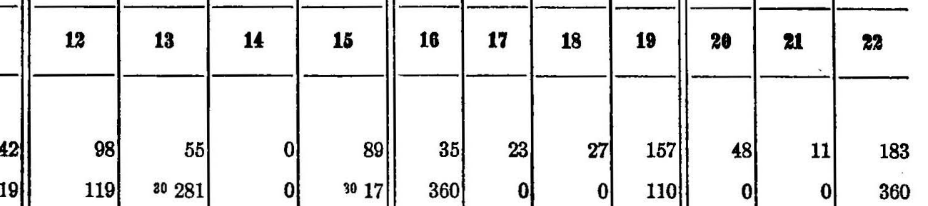

One Two Three Four Men $\begin{aligned} & \text { Wom. } \\ & \text { en }\end{aligned} \begin{aligned} & \text { Men } \\ & \text { and } \\ & \text { women }\end{aligned}$

\begin{tabular}{rr|r|r|r|r|r|r|r}
67 & 84 & 51 & 24 & 2 & 10 & 3 & 1 & 242 \\
110 & 1 & 5 & 3 & 0 & 0 & 0 & 0 & 119
\end{tabular}

畧

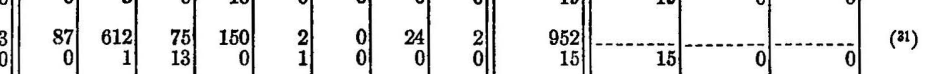

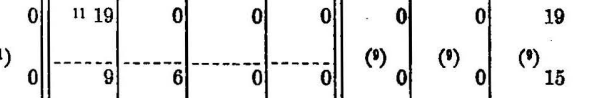

点

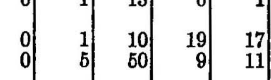

000

00348

10

\begin{tabular}{r|r|r|r|r|r}
29 & 45 & 94 & 3 & 26 & \\
0 & 9 & 36 & 5 & 0 & 481
\end{tabular}

10.185

\begin{tabular}{r|r|r}
0 & 0 & 0 \\
0 & 5 & 36 \\
40 & 50 & 50
\end{tabular}

\begin{tabular}{|l|l|l|l|l|}
0 & 50 & 0 & 0 \\
0 & 3 & 0 & 0 & 0
\end{tabular}

$\begin{array}{lll}0 & 0\end{array}$

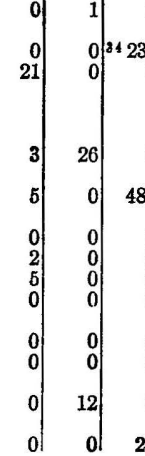

\begin{tabular}{ll|}
3 & 10 \\
0 & 15
\end{tabular}

$234 \quad 356$

1,110
77

0

(33)

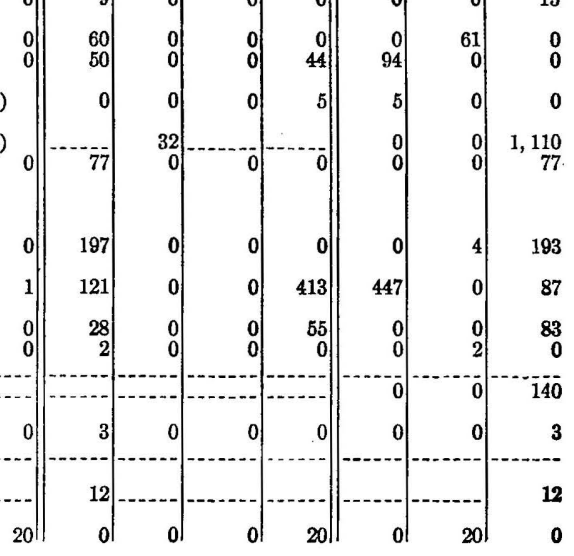




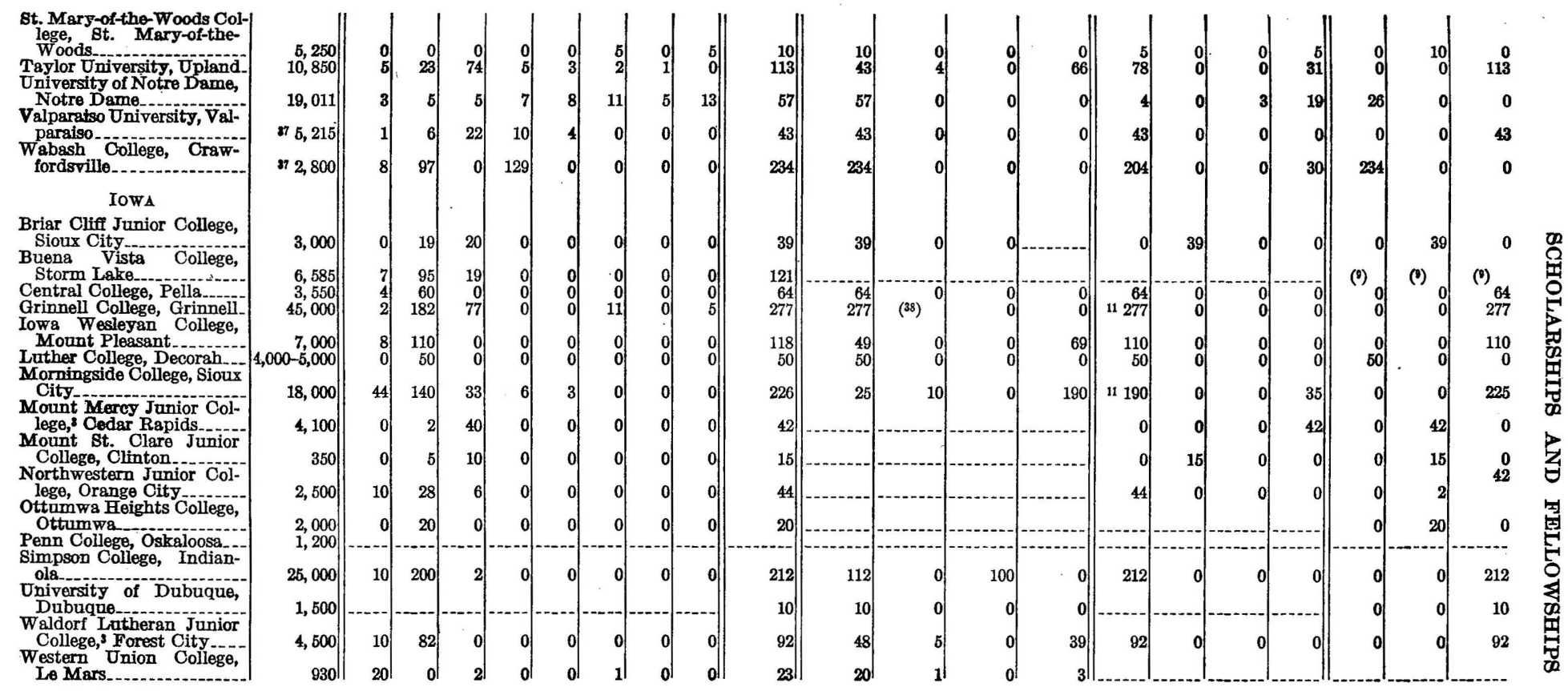

3 Junior college.

is Mayber not report

${ }_{30}$ Loans and part-time jobs not treated as scholarships.

31 About 200 students do part-time clerieal work.

a2 In addition the college reported 89 students receiving financial aid.

${ }_{3}$ Assistance through means of service given to 20 students (men and women), totaling $\$ 3,000$.

34 812 scholarships have a value range of $\$ 50-\$ 200 ; 234$ a range of $\$ 200-\$ 350$.

${ }_{26}$ Free scholarships to the amount of $\$ 103,385$; scholarships involving a moral obligation to be repaid, $\$ 4,303$; and service scholarships, $\$ 76,425$.

27 Funds are also available for part-time campus jobs and student loans. 
TABLE 9.-SCHOLARSHIPS AVAILABLE AT PRIVATELY SUPPORTED UNIVERSITIES AND COLLEGES, 1934-35-Contd.

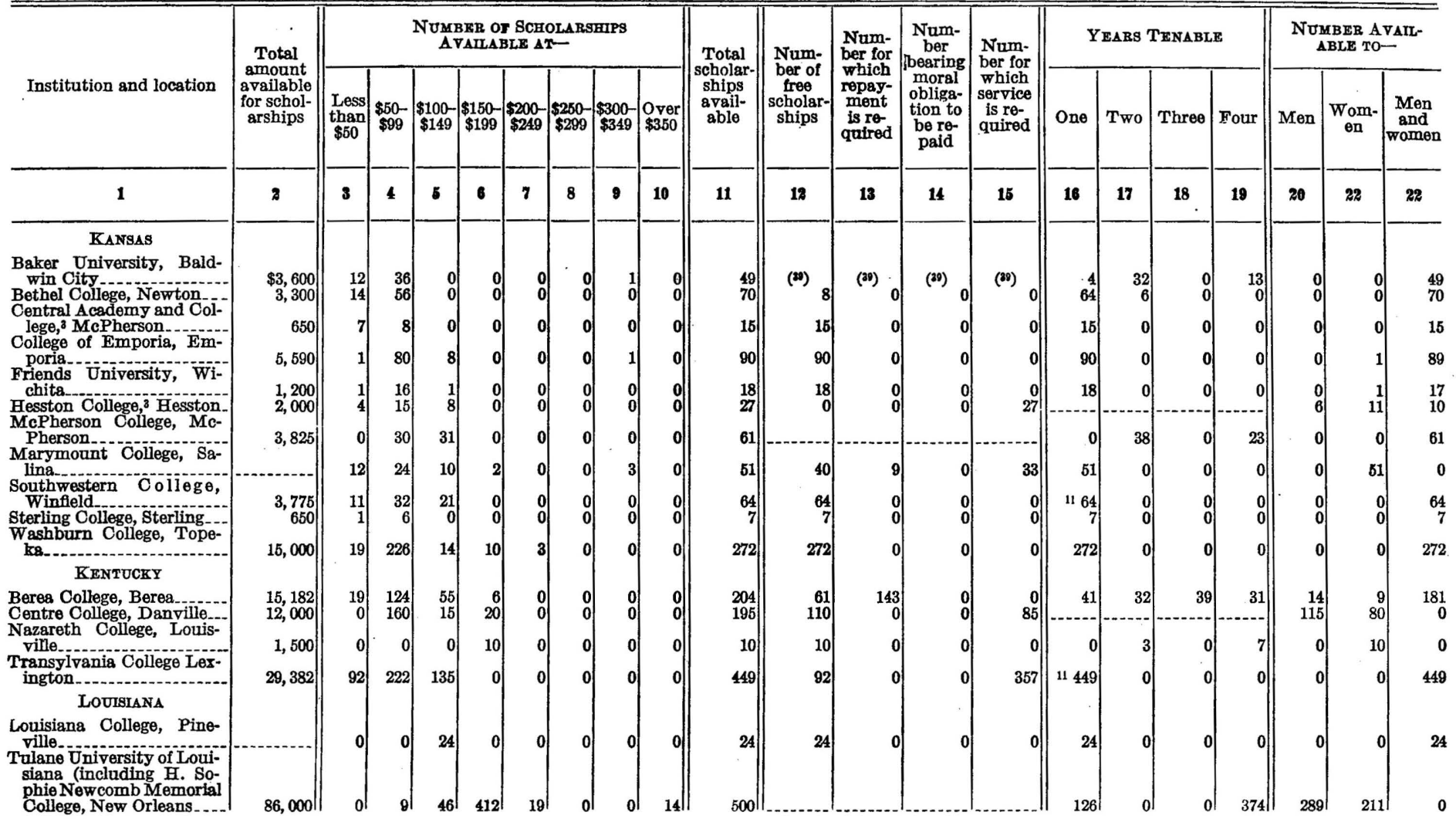




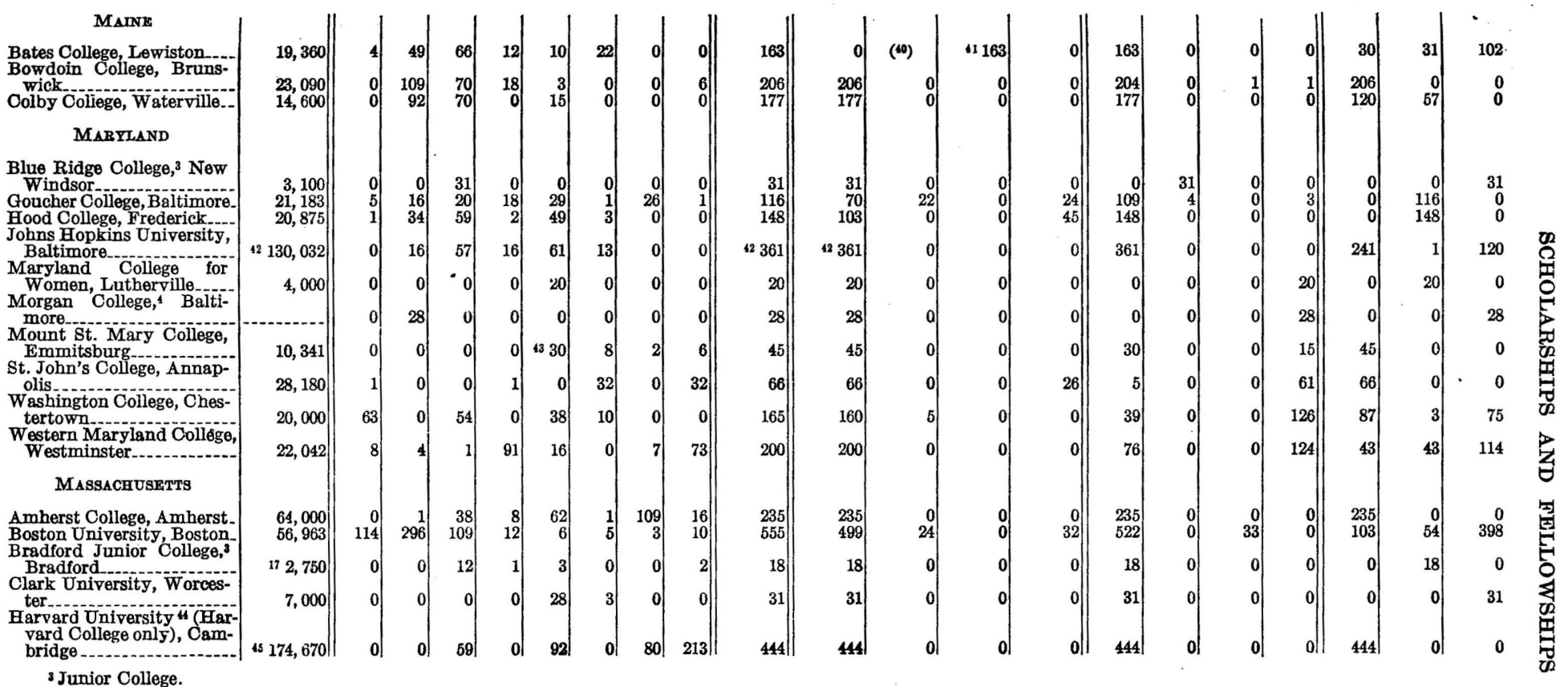

Junior College.

11 May be renewed.

30 A pproximately.

$40 \$ 12,000$ for loans. Not included in scholarships.

\$1 All scholarships to be repaid "if possible." versity reported grants as follows: 29 at $\$ 300-\$ 399 ; 117$ at $\$ 400-\$ 499 ; 29$ at $\$ 500-\$ 749 ; 4$ at $\$ 70-\$ 999 ; 19$ at $\$ 1,000-\$ 1,499$.

43 For 1935-36.

15 Includes $\$ 7,400$ for fellowships as follows: 2 at $\$ 400-\$ 499 ; 3$ at $\$ 500-\$ 749 ; 2$ at $\$ 700-\$ 999 ; 3$ at $\$ 1,000-\$ 1,499$. 
TABLE 9.-SCHOLARSHIPS AVAILABLE AT PRIVATELY SUPPORTED UNIVERSTTIES AND COLLEGES, 1934-35-Contd.

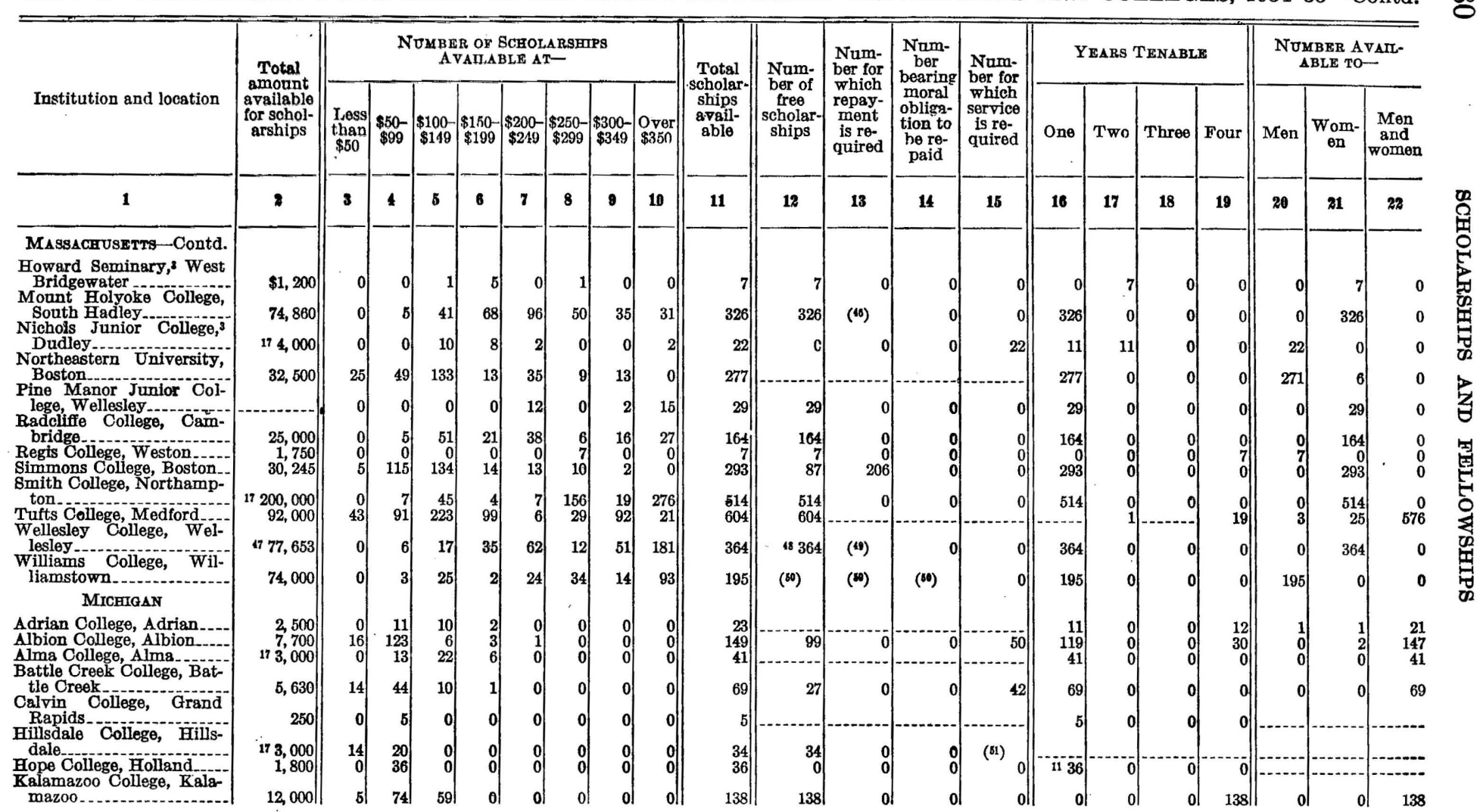




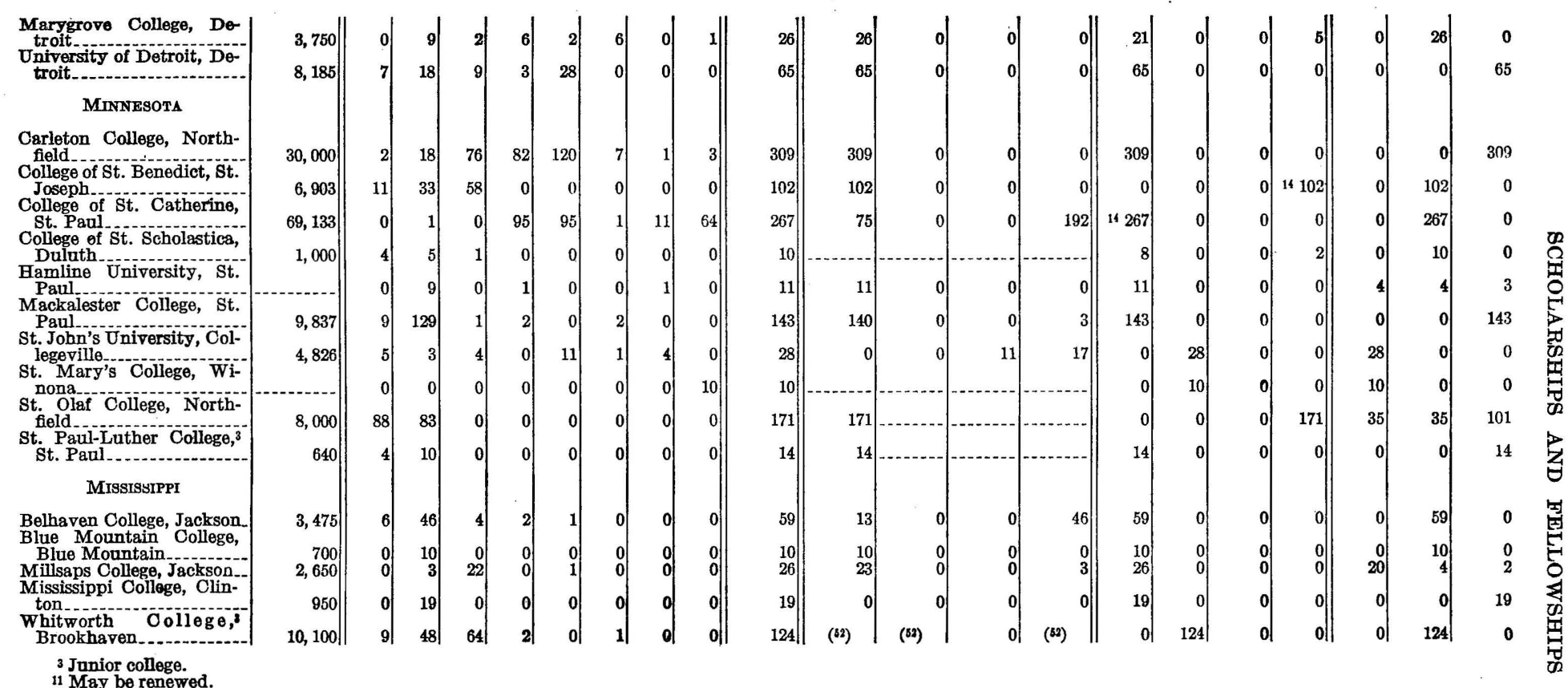

3 Junior college.
is May be renewed.

14 All scholarships are for 1 year, but may be renewed if earned by scholastic attainment.

17. Approximately.

${ }_{77}$ Plus 165 places in cooperative houses. A place in a cooperative house carries an allowance of $\$ 300$ on college fees.

18 Except 1-hour service a day from students living in cooperative houses.

so $\$ 31,000$ for free scholarships; $\$ 3,000$ for loan scholarships; and $\$ 40,000$ for scholarships involving a moral obligation to be repaid.

in 80 service appointments made at $\$ 25-\$ 50$.

s $\$ 4,000$ for free scholarships, $\$ 100$ for loan, and $\$ 6,000$ for service scholarships. 
TABLE 9. SCHOLARSHIPS AVAILABLE AT PRIVATELY SUPPORTED UNIVERSTTIES AND COLLEGES, 1934-35-Contd.

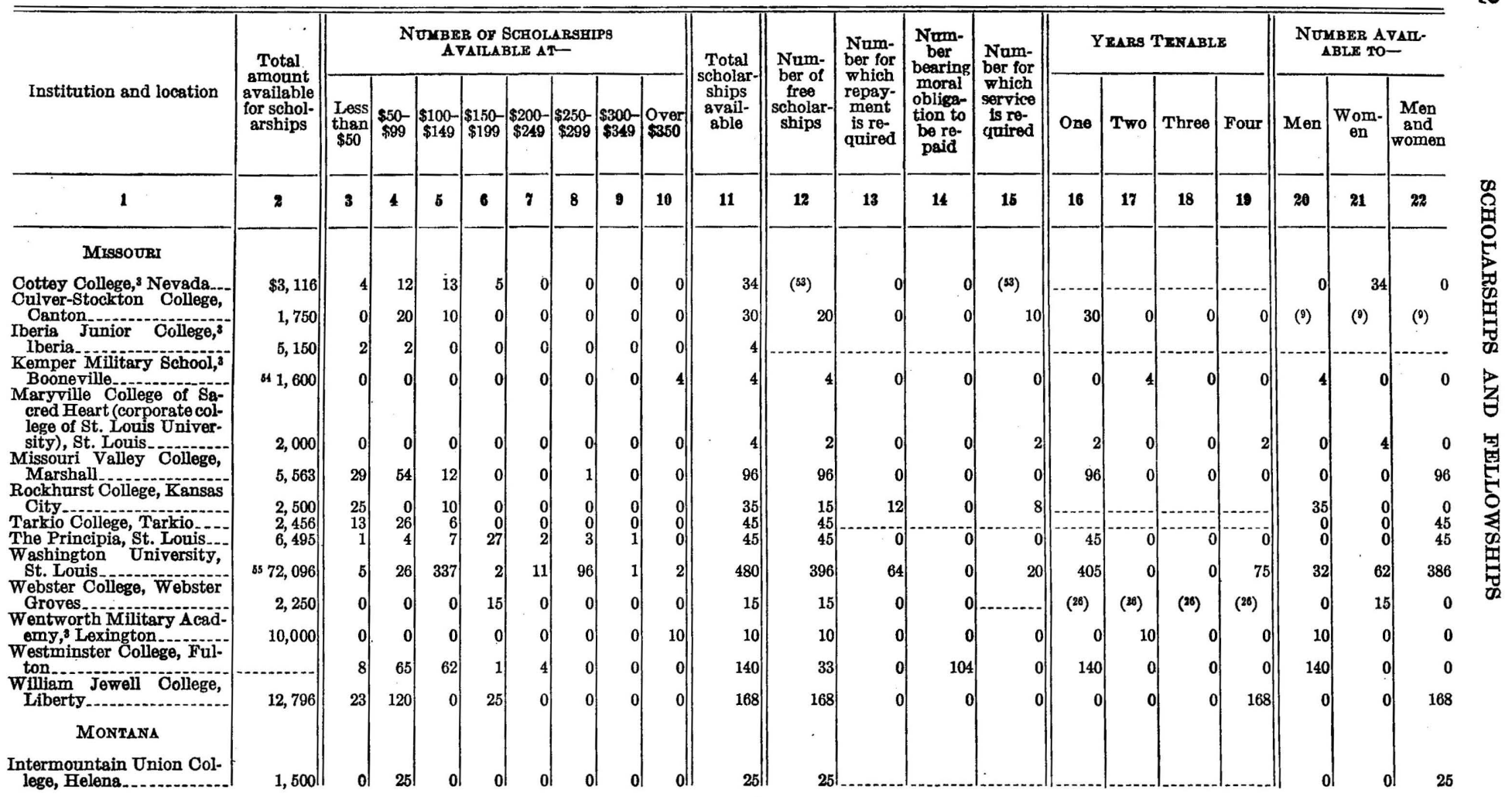




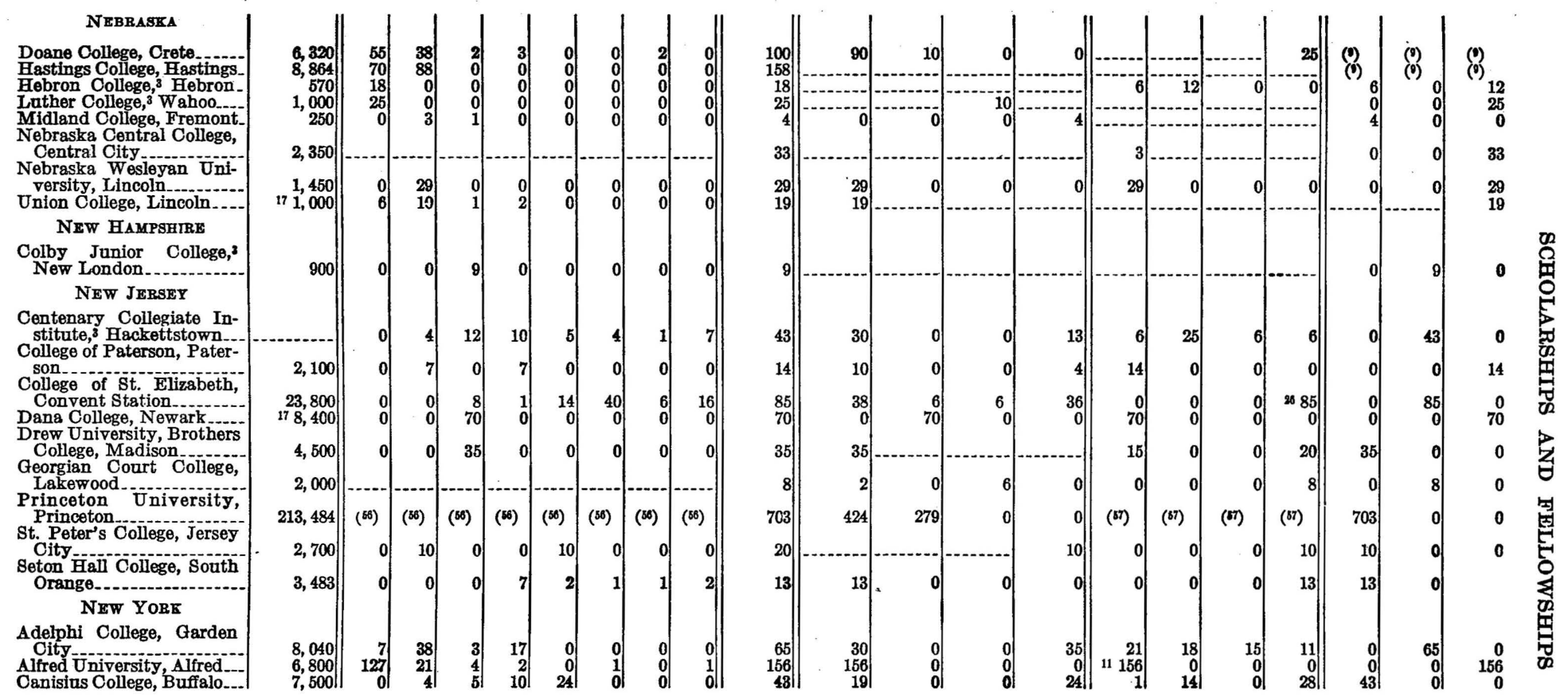

8 Junior college.

11 Number not reported.

17 Approximately.

26 Depending upon scholarship.

${ }_{33} \$ 650$ for free scholarships; $\$ 2,466$ for service scholarships.

in addition, a fund is available for the use of bona fide candidates for the ministry. During 1934-35, 4 cadets were beneflciaries of this fund.

so Impossible to segregate by size of grant.

s7 Dependent upon fulfillment of university regulations regarding scholarships. 
TABLE 9.-SCHOLARSHIPS AVAILABLE AT PRIVATELY SUPPORTED UNIVERSITIES AND COLLEGES, 1934-35-Contd.

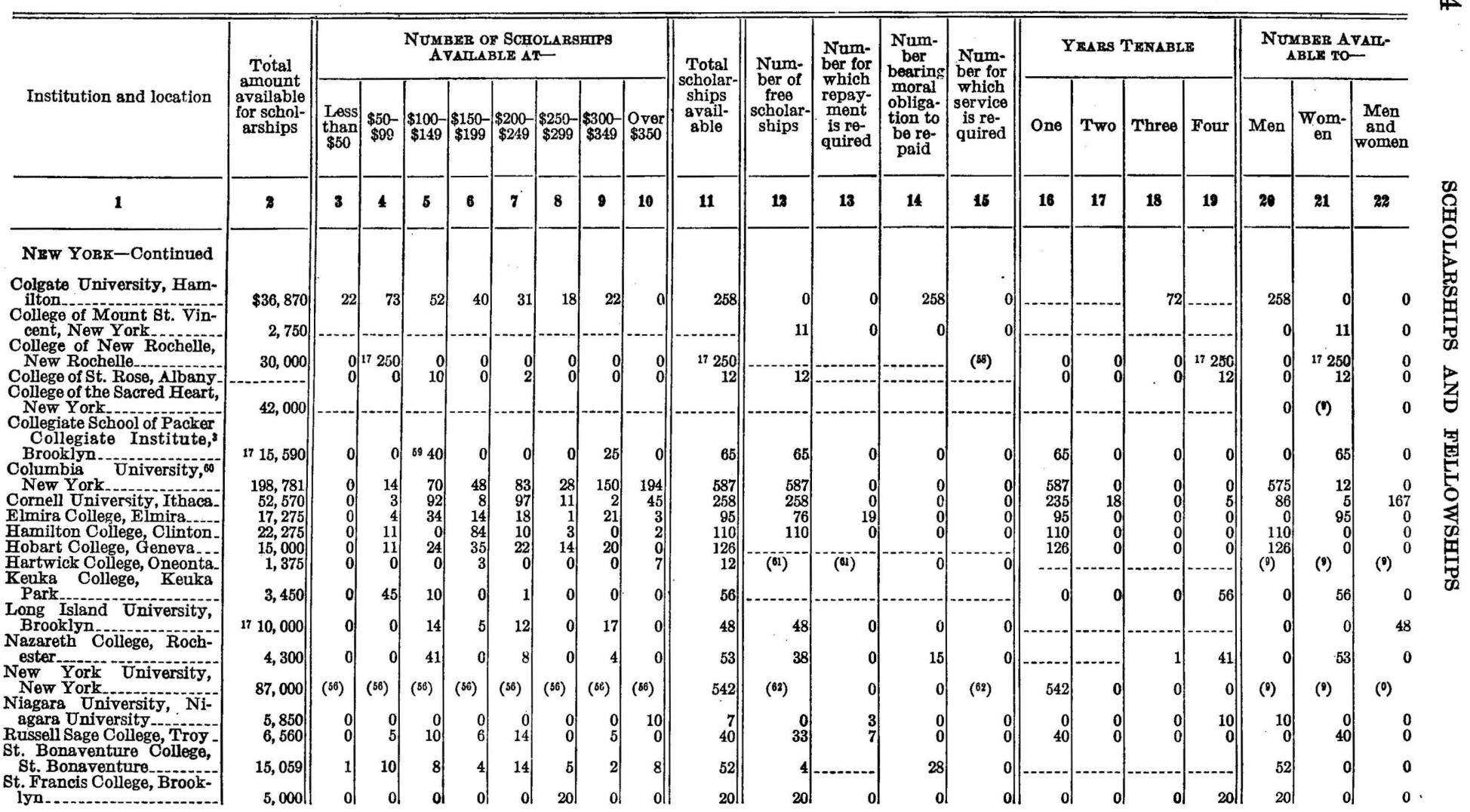




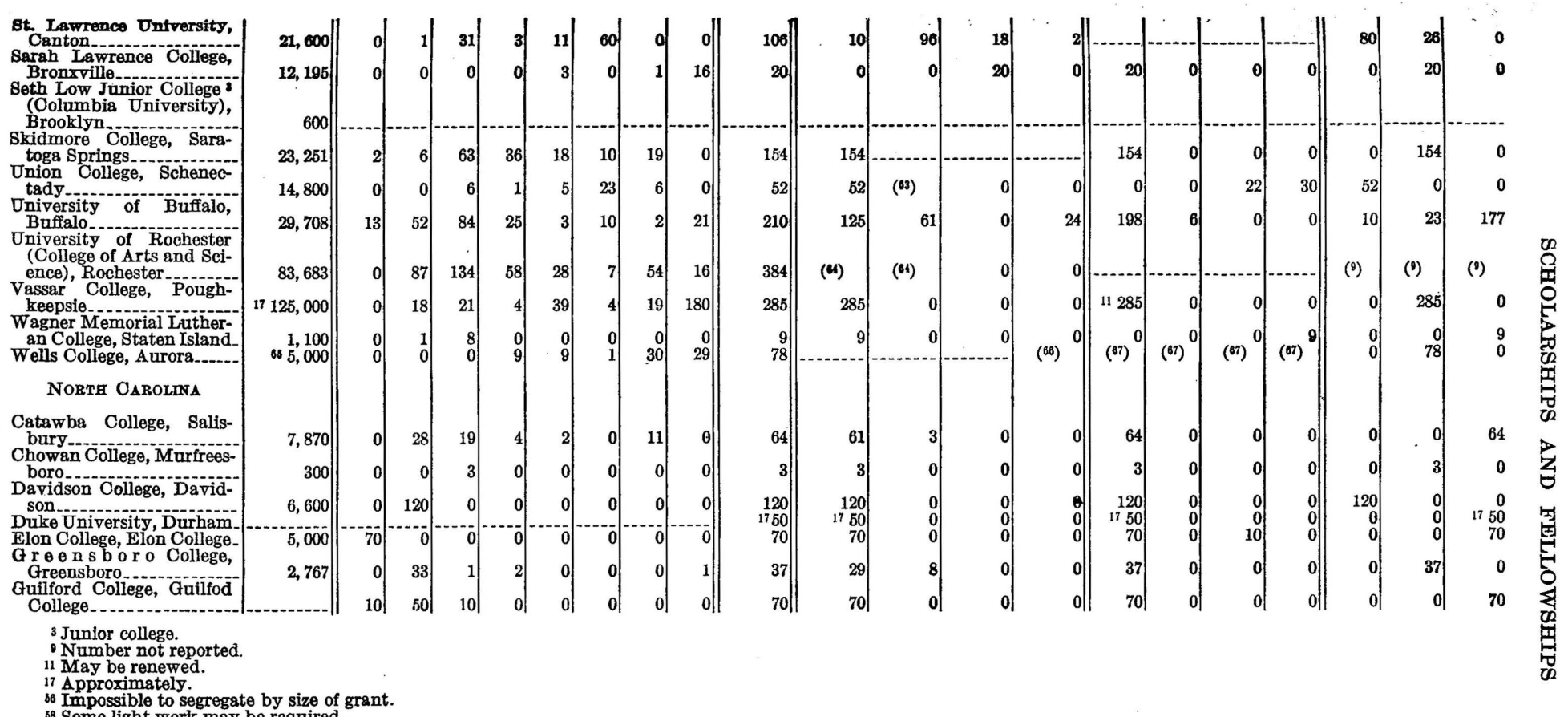

${ }^{6} 8$ Some light work may be required.

${ }_{60}$ Not including Bard College, Barnard College (both of which provide scholarships), Seth Low Junior College, or Teachers College. The first two failed to report; the other

o are listed separately.

$61 \$ 625$ in free scholarships, and $\$ 750$ in scholarships involving a moral obligation to be repaid.

os $\$ 72,000$ in free scholarships; $\$ 15,000$ in service seholarships.

$63 \$ 15,000$ in loans annually.

$64 \$ 59,947$ in free scholarships; $\$ 23,736$ in loans.

o6 Six hours a week work required from any scholarship holder. 
TABLE 9.-SCHOLARSHIPS AVAILABLE AT PRIVATELY SUPPORTED UNIVERSITIES AND COLLEGES, 1934-35-Contd.

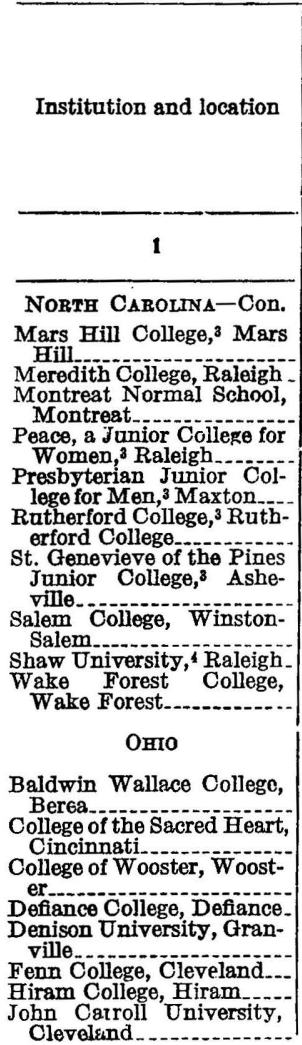

\begin{tabular}{|c|c|c|c|c|c|c|c|c|c|}
\hline \multirow{2}{*}{$\begin{array}{c}\text { Total } \\
\text { amount } \\
\text { available } \\
\text { for schol- } \\
\text { arships }\end{array}$} & \multicolumn{9}{|c|}{$\begin{array}{l}\text { NUKBER OF SCHOLARSHIPS } \\
\text { AVAILABLE AT- }\end{array}$} \\
\hline & \begin{tabular}{|l|} 
Less \\
than \\
$\$ 50$
\end{tabular} & $\$ 50-$ & $\$ \$ \$ 140-$ & $\$$ & $\$ 200-$ & $\$ 250$ & $\$ 30$ & & $\begin{array}{l}\text { Over } \\
\$ 350\end{array}$ \\
\hline 2 & 3 & 4 & 5 & 6 & $y$ & 8 & 9 & & 10 \\
\hline $\begin{array}{r}\$ 1,035 \\
2,660\end{array}$ & $\begin{array}{l}0 \\
0\end{array}$ & ? & $\begin{array}{r}0 \\
24\end{array}$ & $\begin{array}{l}0 \\
0\end{array}$ & o & $\begin{array}{l}0 \\
0\end{array}$ & . & $\begin{array}{l}0 \\
0\end{array}$ & 0 \\
\hline 3,835 & 2 & 3 & & 2 & 0 & 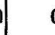 & ) & 0 & 1 \\
\hline 2,000 & 0 & 20 & 10 & 0 & 0 & 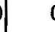 & & 0 & 0 \\
\hline 6,000 & 46 & 66 & 0 & 0 & 0 & 1 & & 0 & 0 \\
\hline 375 & 0 & 5 & 0 & 0 & 0 & 0 & & 0 & 0 \\
\hline 1,200 & 0 & 0 & 2 & 0 & 0 & ( & 0 & 0 & -1 \\
\hline $\begin{array}{r}17,500 \\
960\end{array}$ & $\begin{array}{l}0 \\
0\end{array}$ & $\begin{array}{r}5 \\
15\end{array}$ & $\begin{array}{r}33 \\
0\end{array}$ & $\begin{array}{r}46 \\
0\end{array}$ & 13 & 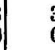 & & 0 & $\begin{array}{l}2 \\
0\end{array}$ \\
\hline 7,500 & 0 & 0 & 150 & 0 & 0 & 0 & & 0 & 0 \\
\hline 17,583 & 23 & 103 & 53 & 13 & 15 & 1 & 1 & 0 & 1 \\
\hline 60 & 0 & 0 & 0 & 0 & 0 & c & 이 & 2 & 0 \\
\hline $\begin{array}{r}19,965 \\
1,270\end{array}$ & $\begin{array}{r}0 \\
17\end{array}$ & $\begin{array}{l}83 \\
10\end{array}$ & $\begin{array}{r}140 \\
0\end{array}$ & $\begin{array}{l}0 \\
1\end{array}$ & 0 & 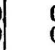 & 0 & 0 & $\begin{array}{l}0 \\
0\end{array}$ \\
\hline $\begin{array}{r}19,000 \\
5,000 \\
6,100\end{array}$ & \begin{tabular}{rr|}
60 & 51 \\
0 & 0 \\
& 0
\end{tabular} & $\begin{array}{r}6092 \\
6 \\
60\end{array}$ & $\begin{array}{r}20 \\
2 \\
16\end{array}$ & $\begin{array}{r}15 \\
26 \\
3\end{array}$ & 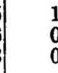 & 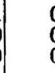 & 0 & 0 & $\begin{array}{l}0 \\
0 \\
0\end{array}$ \\
\hline 5,000 & 0 & 0 & 24 & 0 & 8 & c & a) & 0 & \\
\hline
\end{tabular}

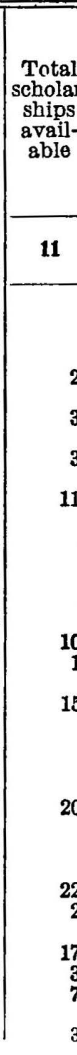

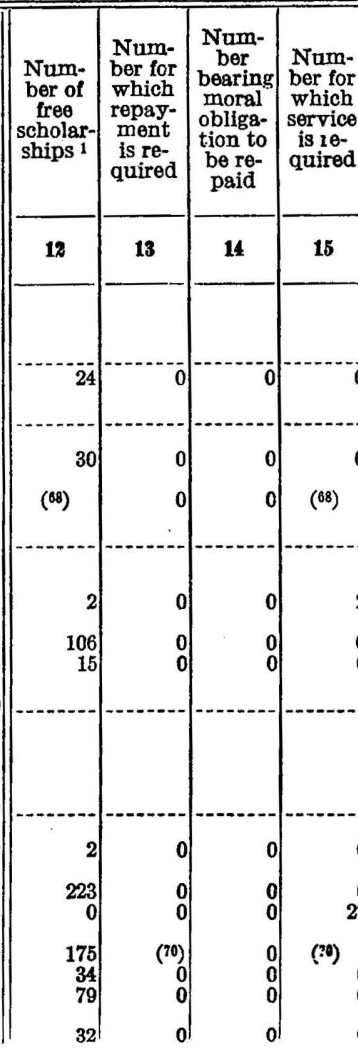

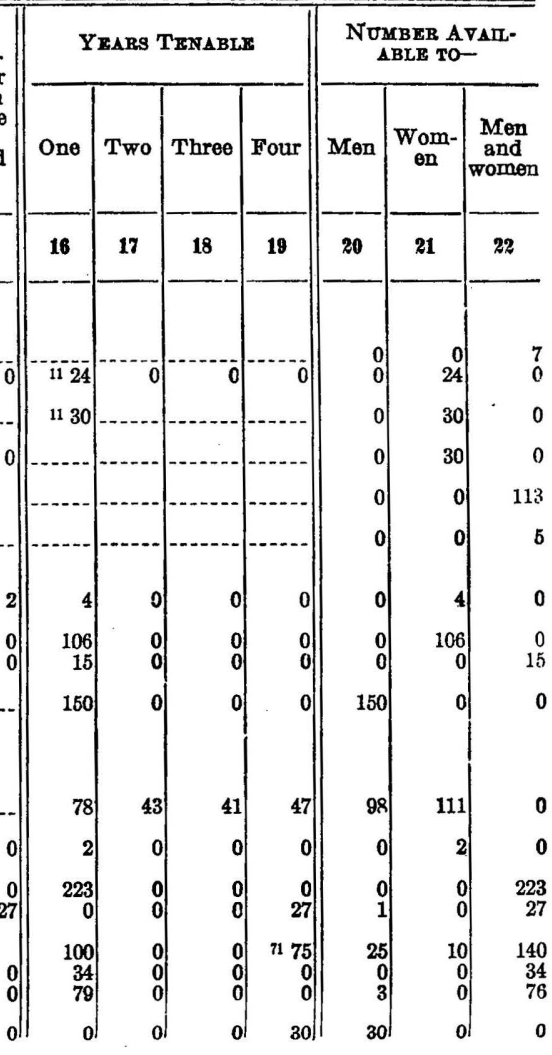




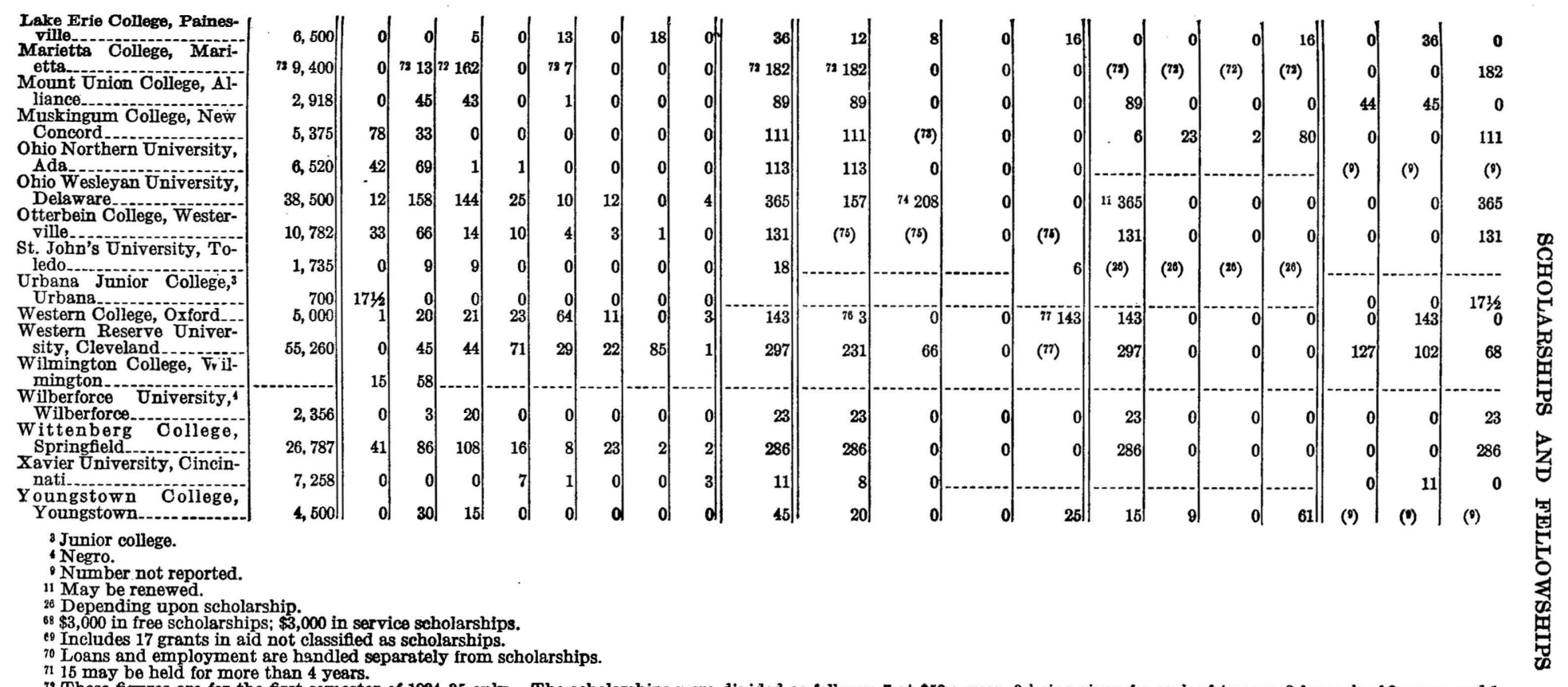

72 These figures are for the first semester of 1934-35 only. The scholarships were divided as follows: 7 at $\$ 50$ a year, 3 being given for each of 4 years, 3 for each of 3 years, and 1 for each of 2 years; 23 at $\$ 50$ a semester for each of 2 years; 139 at $\$ 50$ a semester; 6 at $\$ 25$ a semester; 7 at $\$ 100$ s semester.

74 All of these are on a half-loan and half-gift basis.

76 \$3,894 in free scholarships; $\$ 1,185$ in loans; $\$ 5,703$ in service seholarships.

7 Bome slight service expected. 
TABLe 9.-SCHOLARSHIPS AVAILABLE AT PRIVATELY SUPPORTED UNIVERSITIES AND COLLEGES, 1934-35-Contd.

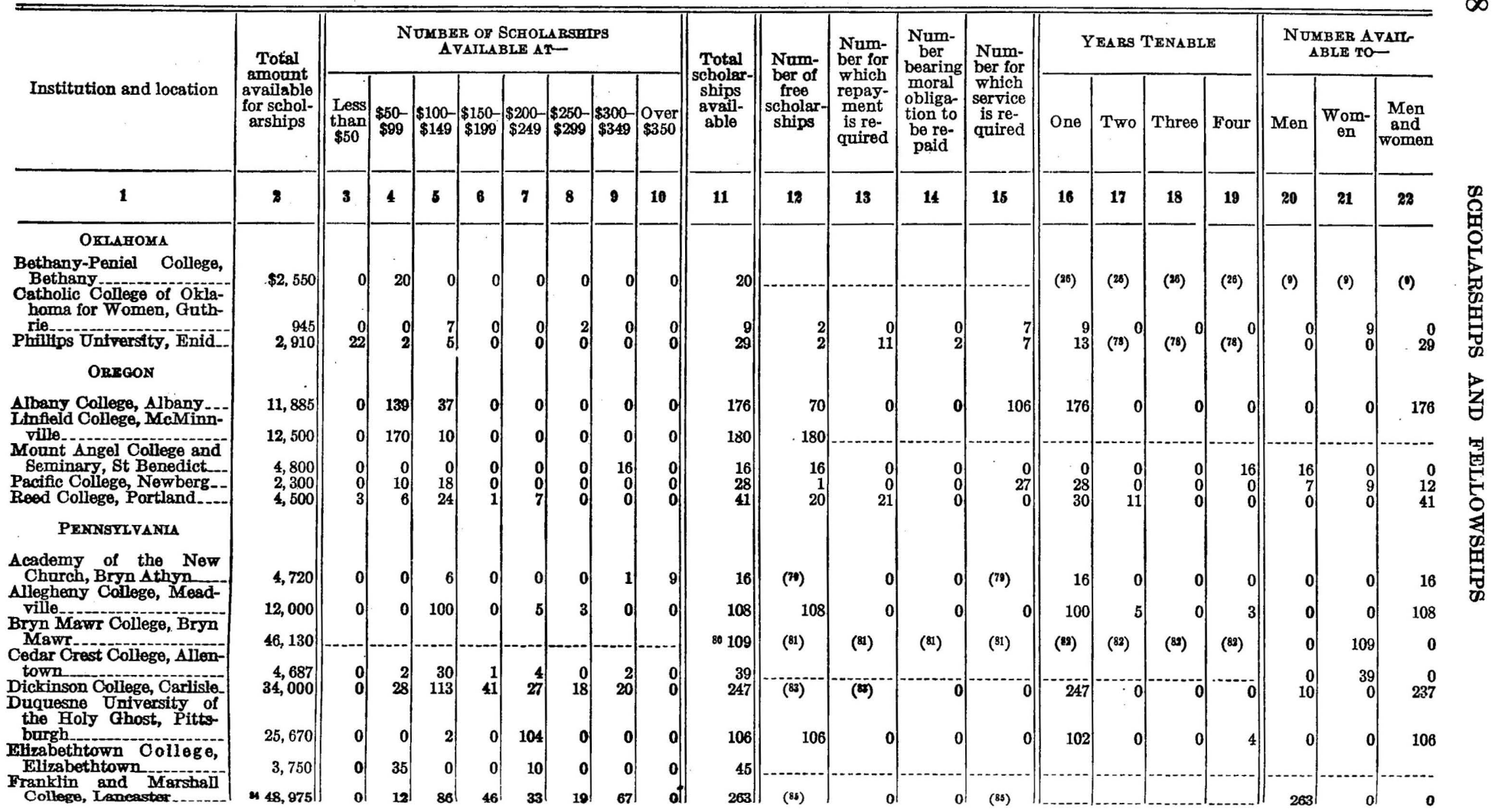


Geneva College, Beaver

Grove City College, Grove Haverford College, HaverJuniata College, HuntingLafayette College, Easton. La Salle College, Philadelphia Annville-........... Lehigh University, Bethl Lincoln University, Moravian Seminary and College, Bethlehem ...... Penn Hall, ${ }^{3}$ Chambersburg. ennsylvania College for

St. Francis College, Loretto

St. Thomas College, ScranSusquehanna Üniversity, swarthmore College, Swarth Unive...........

delphia ............... Thiel College, GreenvilleUniversity of Pittsburgh,

3 Junior college.

- Number not reported.

11 May be renewed.

${ }_{78} 16$ may be renewed.

$70 \$ 2,315$ in fre scholarships: $\$ 2,405$ in service scholarships.

80 The values of annual scholarships range from $\$ 100-\$ 700$. Other scholarships in varying amounts from $\$ 50$ to $\$ 1,000$, have been awarded in recent years, principally from amounts collected through alumnae and friend

None of the scholarships require service nor are they considered loans, but there is a moral obligation applying to a few that when able the amount should be returned. 82 Nearly all scholarships are annual awards, but there are 8 annually renewable for 4 years.

$\$ 24,000$ in free scholarships; $\$ 10,000$ in loans.

No

glowances requiring service to the institution.

$\$ 1,000$ in free scholarships; $\$ 1,750$ in service scholarships.

Number in each group varies from year to year.

so $\$ 2,555$ was not assigned in 1934-35. 
TABLE 9.-SCHOLARSHIPS AVAILABLE AT PRIVATELY SUPPORTED UNIVERSITIES AND COLLEGES, 1934-35-Contd.

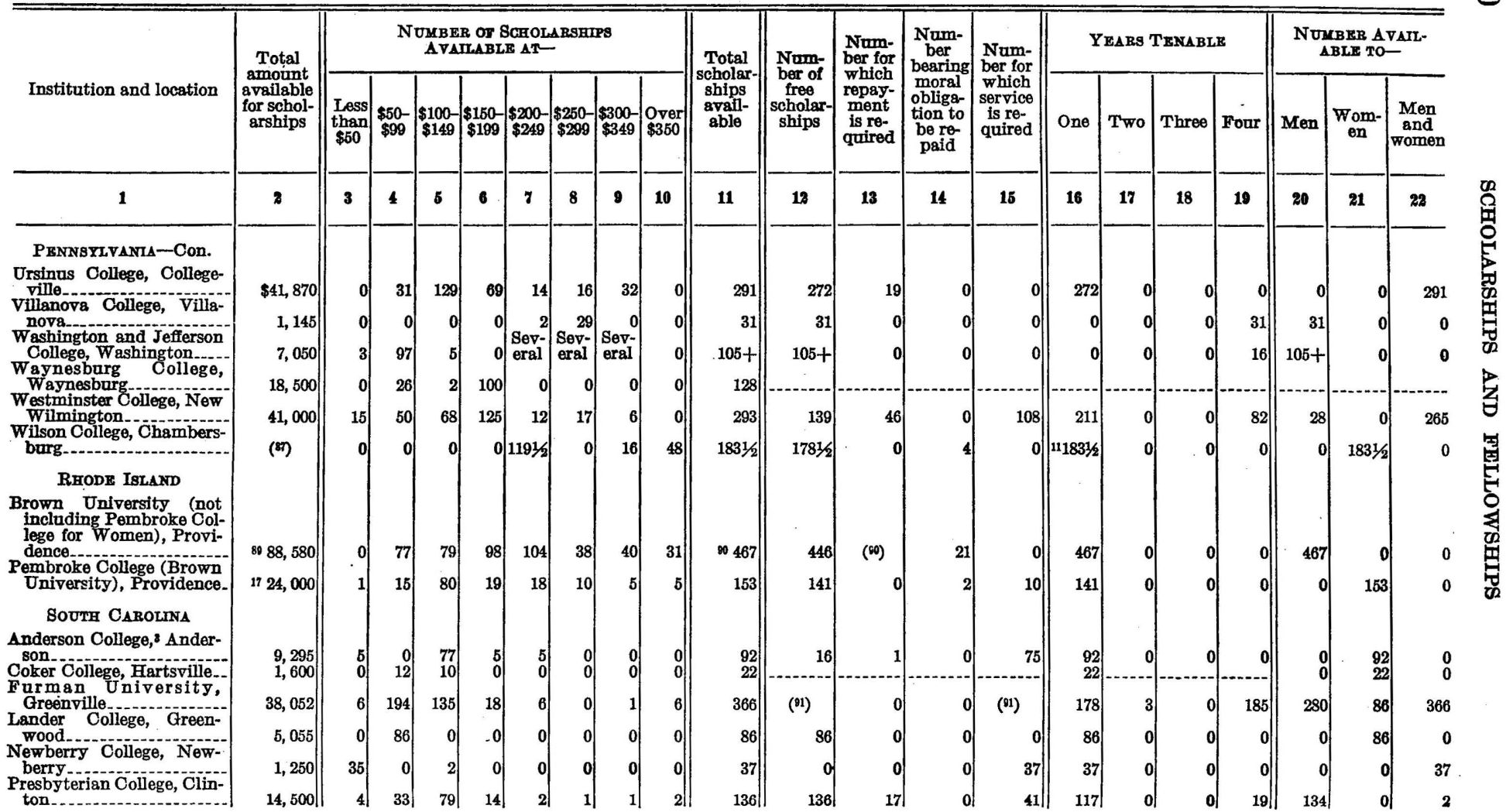




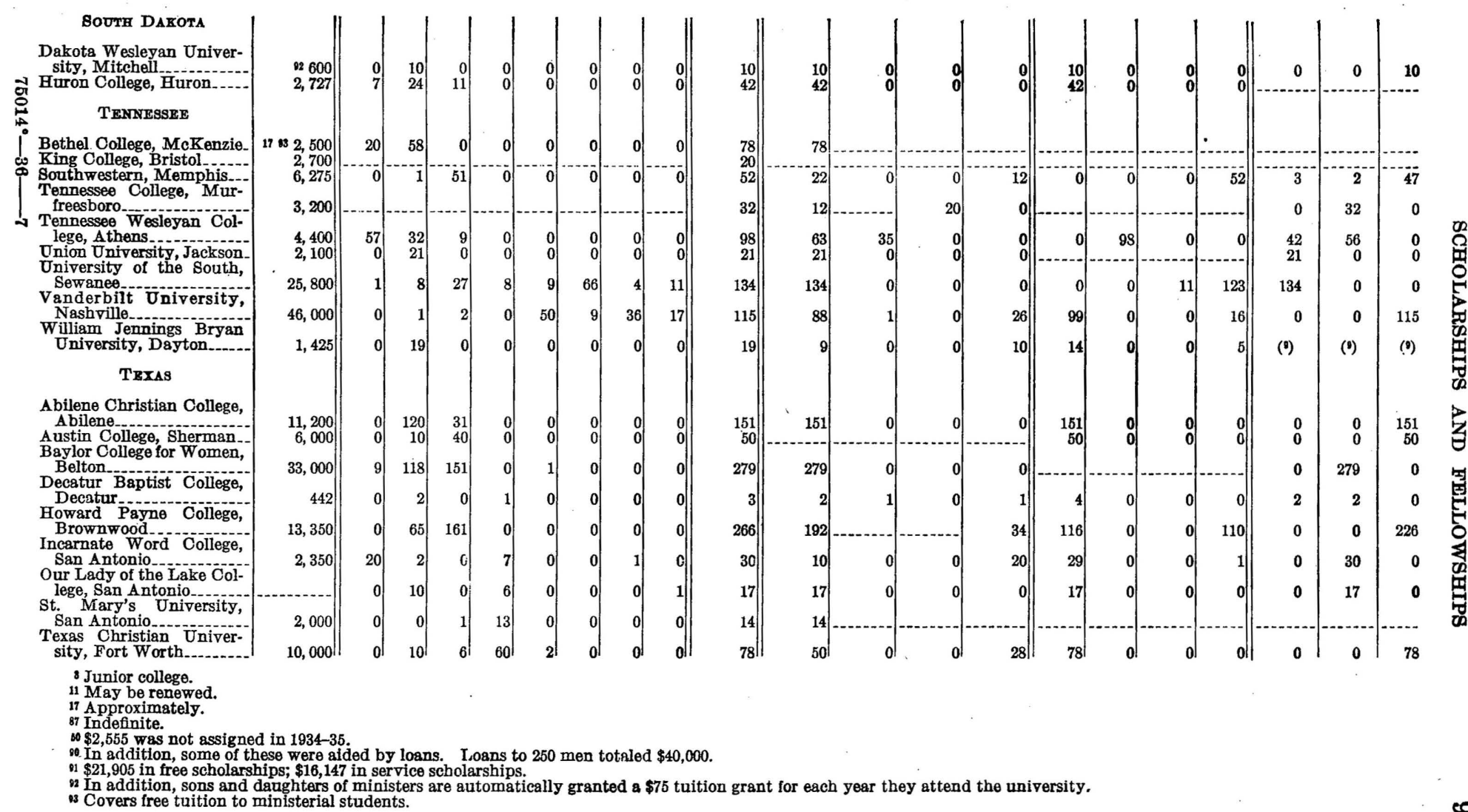


TABLE 9.-SCHOLARSHIPS AVAILABLE AT PRIVATELY SUPPORTED UNIVERSITIES AND COLLEGES, 1934-35-Contd.

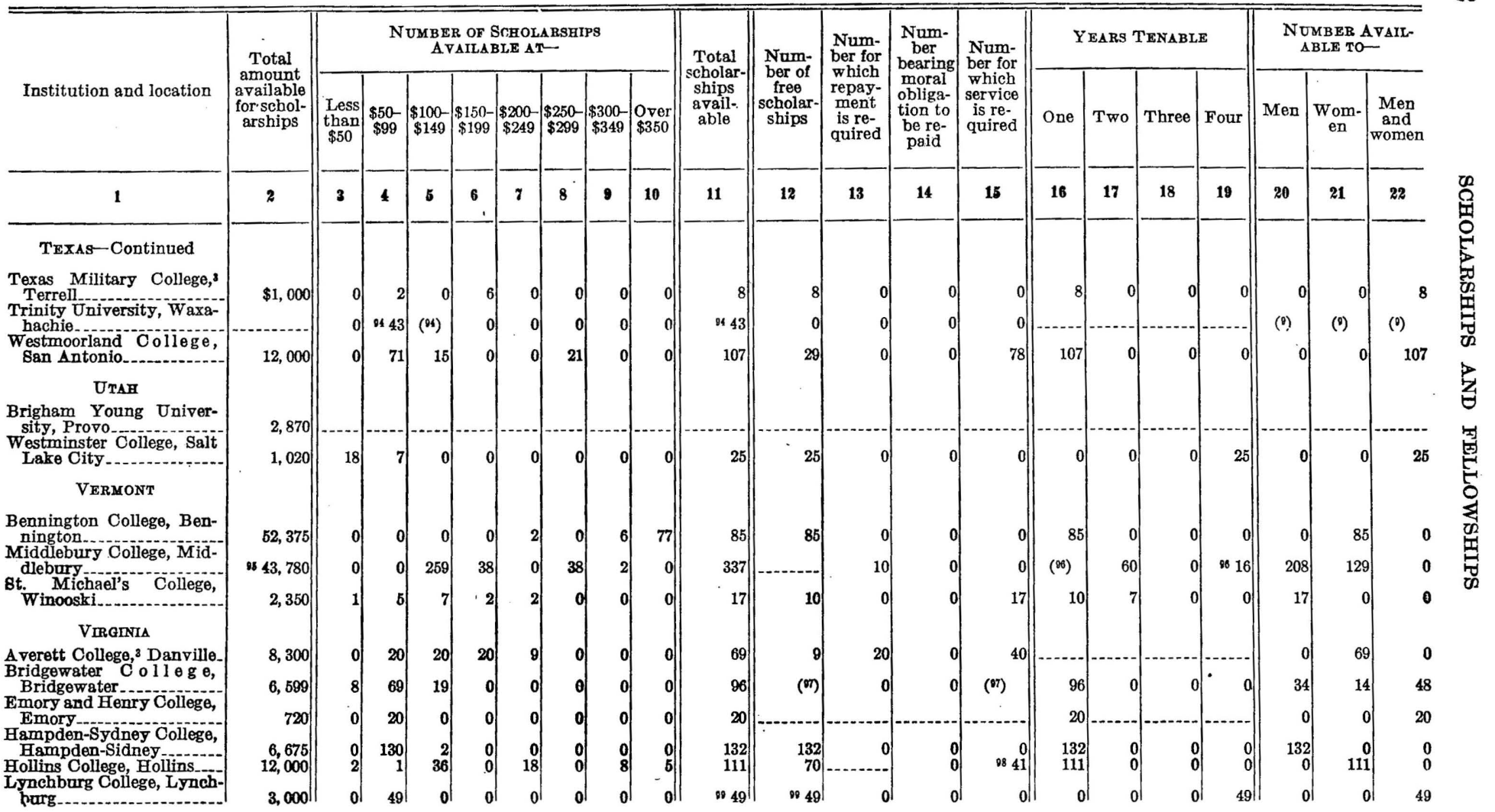




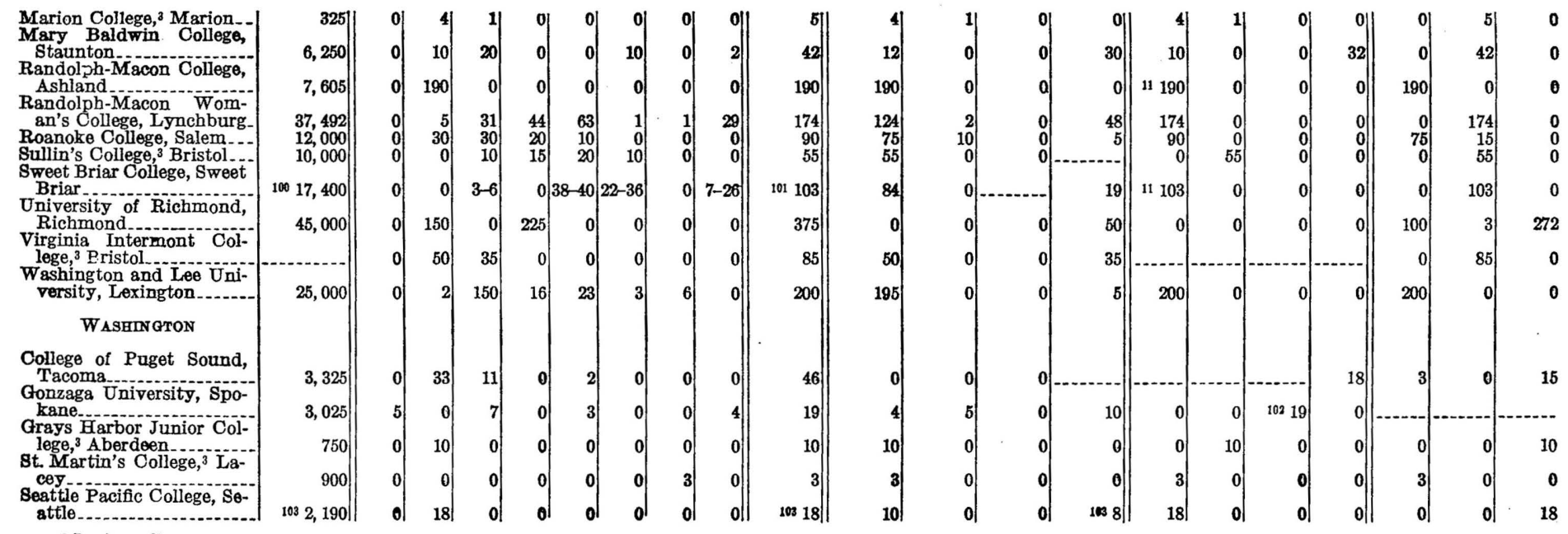

3 Junior college.

Number not reported.

11 May be renewed.

in and and and ters of ministars, sch the or service is required for any of these scholarships.

96261 one-year scholarships and 16 four-year scholarships are held subject to the attainment of satisfactory grades.

${ }^{97} \$ 4,291$ in free scholarships; $\$ 2,308$ in service scholarships.

is 31 of these received free scholarships also.

100 All are for training young men and women for Christion service.

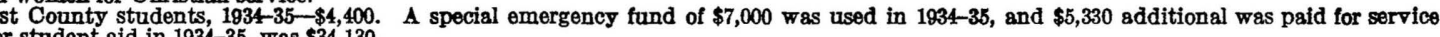
10 P uns special stodent

${ }_{103}$ More than 80 service scholarships, about 40 at $\$ 60$ a year, and the rest for about $\$ 120$ a year, are applied toward residence hall expenses and tuition. These are for 1 year, and are open to both men and women. 
TABLE 9.-SCHOLARSHIPS AVAILABLE AT PRIVATELY SUPPORTED UNIVERSITIES AND COLLEGES, 1934-35-Con.

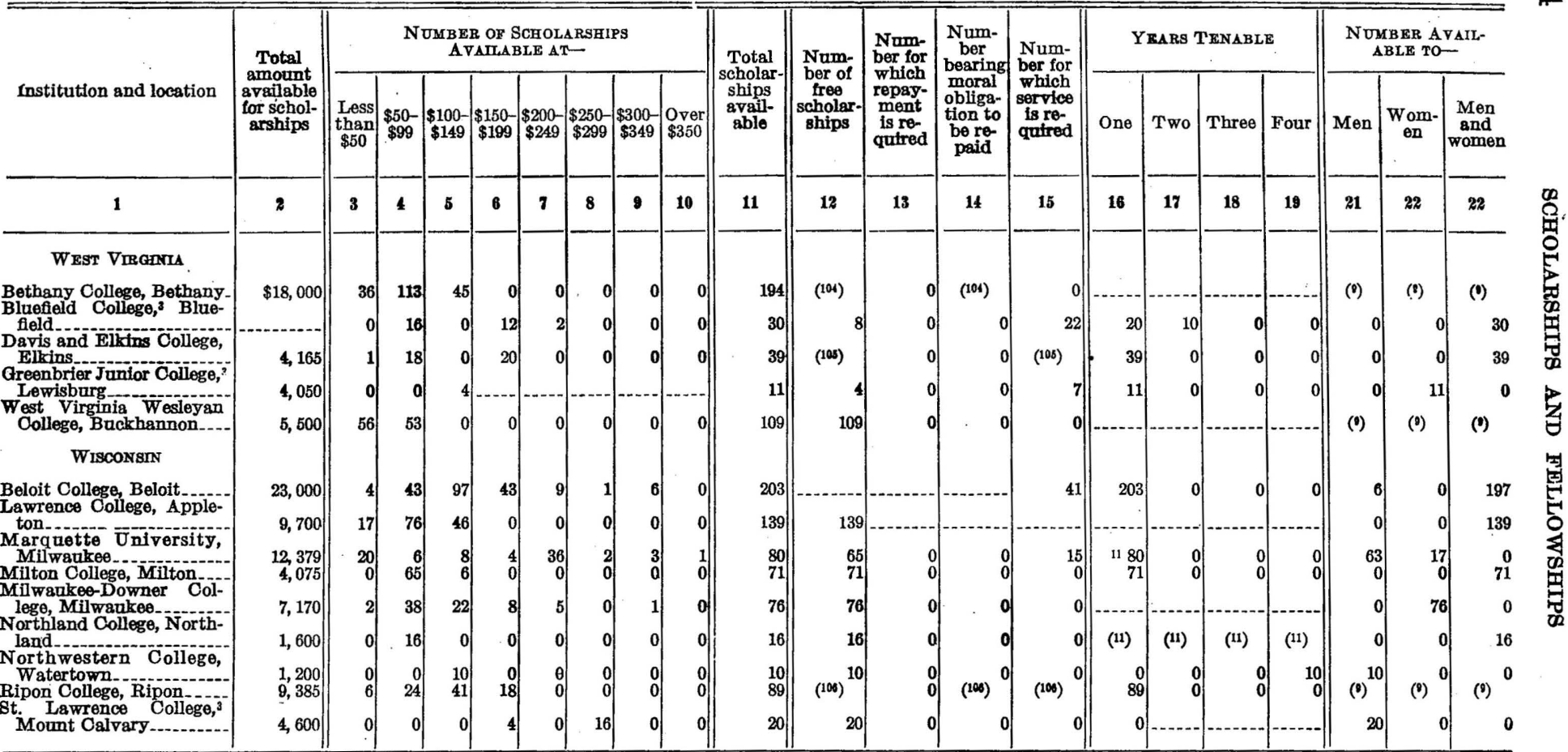

3 Junior college.

${ }_{100}^{100} \$ 10,000$ in free scholarships: $\$ 8,000$ in scholarships for which there is a moral obligation to be repaid.

11 May be renewed.

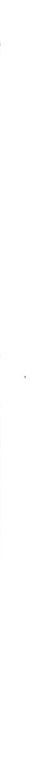


TABLE 10.-FELLOWSHIPS AVAILABLE AT PRIVATELY SUPPORTED COLLEGES AND UNIVERSITIES, 1934-35

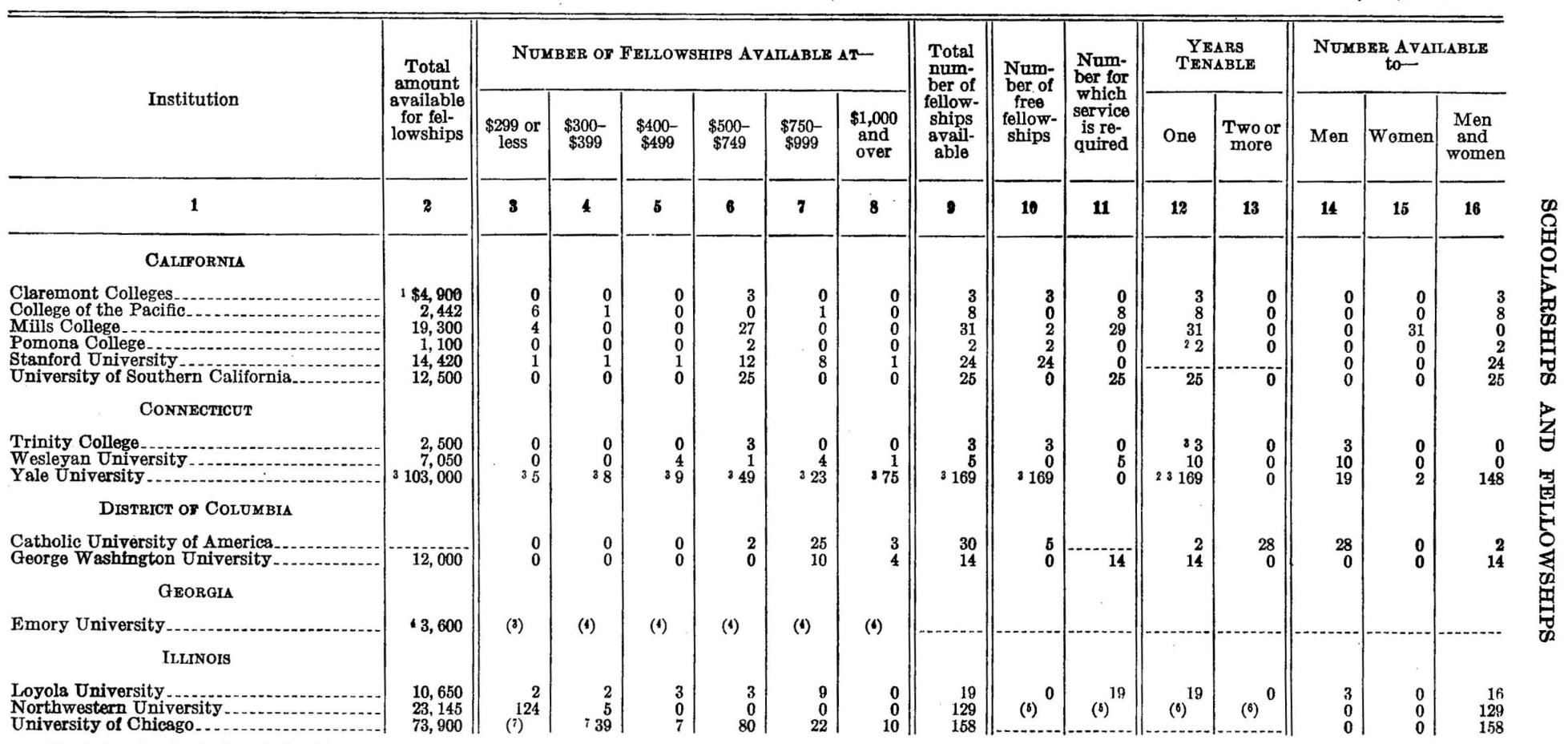

1 Includes also funds for scholarships.

2 May be renewed.

For scholarships for graduate study, distributed as follows: 3 at $\$ 50-\$ 99 ; 3$ at $\$ 150-\$ 199 ; 13$ at $\$ 200-\$ 249$. All require service; all tenable for 1 year.

Fow do departmental assisting.

i Granted each semester. $\$ 300-\$ 309$. 
TABL 10.-FELLOWSHIPS AVAILABLE AT PRIVATELY SUPPORTED COLLEGES AND UNIVERSITIES, 1934-35-Contd.

\begin{tabular}{|c|c|c|c|c|c|c|c|c|c|c|c|c|c|c|c|}
\hline \multirow[b]{2}{*}{ Institution } & \multirow{2}{*}{$\begin{array}{c}\text { Total } \\
\text { amount } \\
\text { availabble } \\
\text { lor fel- } \\
\text { lowships }\end{array}$} & \multicolumn{6}{|c|}{ NUMBER OF FELLOWSHIPS AVATLABLE $\triangle T-$} & \multirow{2}{*}{$\begin{array}{l}\text { Total } \\
\text { num- } \\
\text { ber of } \\
\text { fellow- } \\
\text { ships } \\
\text { avail- } \\
\text { able }\end{array}$} & \multirow{2}{*}{$\begin{array}{c}\text { Num. } \\
\text { ber of } \\
\text { free } \\
\text { fellow- } \\
\text { ships }\end{array}$} & \multirow{2}{*}{$\begin{array}{l}\text { Num- } \\
\text { ber for } \\
\text { which } \\
\text { service } \\
\text { is re- } \\
\text { quired }\end{array}$} & \multicolumn{2}{|c|}{$\underset{\text { TENABLE }}{\text { YEARg }}$} & \multicolumn{3}{|c|}{$\begin{array}{l}\text { NOMBER AVATLABLR } \\
\text { to- }\end{array}$} \\
\hline & & $\begin{array}{c}\$ 299 \text { or } \\
\text { less }\end{array}$ & $\$ 300-$ & $\$ 400-$ & $\$ \$ \$ 740$ & $\$ \$ \$ 7099$ & $\begin{array}{c}\$ 1,000 \\
\text { and } \\
\text { over }\end{array}$ & & & & One & $\begin{array}{c}\text { Two or } \\
\text { more }\end{array} \mid$ & Men & Women & $\begin{array}{l}\text { Men } \\
\text { and } \\
\text { women }\end{array}$ \\
\hline 1 & 2 & 3 & 4 & 5 & 6 & 7 & 8 & 8 & 10 & 11 & 12 & 13 & 14 & 15 & 16 \\
\hline INDIANA & \multirow{3}{*}{$\$ 3,750$} & \multirow{3}{*}{$\cdot 15$} & \multirow{3}{*}{$\begin{array}{l}3 \\
0\end{array}$} & \multirow{3}{*}{$\begin{array}{l}2 \\
0\end{array}$} & \multirow{3}{*}{$\begin{array}{l}2 \\
0\end{array}$} & \multirow{3}{*}{$\begin{array}{l}1 \\
0\end{array}$} & \multirow{3}{*}{$\begin{array}{l}0 \\
0\end{array}$} & \multirow{3}{*}{$\begin{array}{r}9 \\
15\end{array}$} & \multirow{3}{*}{$\begin{array}{l}4 \\
0\end{array}$} & \multirow{3}{*}{$\begin{array}{r}5 \\
15\end{array}$} & \multirow{3}{*}{$\begin{array}{r}9 \\
15\end{array}$} & \multirow{4}{*}{$\begin{array}{l}0 \\
0\end{array}$} & \multirow{4}{*}{$\begin{array}{l}0 \\
0\end{array}$} & \multirow{4}{*}{$\begin{array}{r}0 \\
15\end{array}$} & \multirow{3}{*}{$\begin{array}{l}9 \\
0\end{array}$} \\
\hline $\begin{array}{l}\text { De Pauw University } \\
\text { St. Mary-of-the-Woods Cöliege............ }\end{array}$ & & & & & & & & & & & & & & & \\
\hline $\mathbf{K}_{\Delta \mathrm{NSAS}}$ & & & & & & & & & & & & & & & \\
\hline Washburn College_-........ & \multirow{2}{*}{2,000} & \multirow[t]{2}{*}{10} & \multirow[t]{2}{*}{0} & \multirow[t]{2}{*}{0} & \multirow[t]{2}{*}{0} & \multirow[t]{2}{*}{0} & \multirow[t]{2}{*}{0} & \multirow[t]{2}{*}{10} & & & & & & & \\
\hline LOVISIANA & & & & & & & & & & & & & & & \\
\hline Tulane University of Louisiana & 500 & 2 & 0 & 0 & 0 & 0 & 0 & 2 & & & & & & & \\
\hline MAINE & & & & & & & & & & & & & & & \\
\hline Bowdoin College & 1,100 & 1 & 0 & 1 & 1 & 0 & 0 & 3 & 3 & 0 & 2 & 1 & 3 & 0 & 0 \\
\hline MARYLAND & & & & & & & & & & & & & & & \\
\hline $\begin{array}{l}\text { Goucher College } \\
\text { Hood College }\end{array}$ & $\begin{array}{r}1,750 \\
500\end{array}$ & $\stackrel{0}{2}$ & $\begin{array}{l}0 \\
0\end{array}$ & $\begin{array}{l}0 \\
0\end{array}$ & $\begin{array}{l}0 \\
0\end{array}$ & $\begin{array}{l}1 \\
0\end{array}$ & ${ }^{10} 1$ & $\stackrel{2}{2}$ & 2 & 0 & 2 & 0 & $\begin{array}{l}0 \\
0\end{array}$ & $\stackrel{2}{2}$ & $\begin{array}{l}0 \\
0\end{array}$ \\
\hline 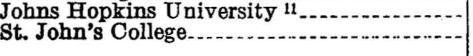 & 1,905 & - & -0 & -- & 3 & -0 & 0 & 3 & -3 & $\overline{0}$ & 3 & 0 & 3 & --1 & $\overline{0}$ \\
\hline MASSACHUSETTS & & & & & & & & & & & & & & & \\
\hline 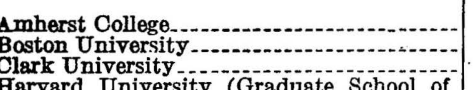 & $\begin{array}{r}17,000 \\
25,658 \\
8,500\end{array}$ & $\begin{array}{r}1 \\
46 \\
5\end{array}$ & $\begin{array}{c}1 \\
23 \\
11\end{array}$ & $\begin{array}{l}0 \\
6 \\
3\end{array}$ & $\begin{array}{r}10 \\
13 \\
1\end{array}$ & $\begin{array}{l}2 \\
4 \\
0\end{array}$ & $\begin{array}{l}4 \\
0 \\
0\end{array}$ & $\begin{array}{l}18 \\
92 \\
20\end{array}$ & $\begin{array}{l}16 \\
50 \\
20\end{array}$ & $\begin{array}{r}2 \\
12 \\
12 \\
0\end{array}$ & $\begin{array}{l}17 \\
90 \\
20\end{array}$ & $\begin{array}{l}1 \\
2 \\
0\end{array}$ & $\begin{aligned} 18 \\
13 \\
0\end{aligned}$ & $\begin{array}{r}0 \\
21 \\
0\end{array}$ & $\begin{array}{r}0 \\
58 \\
20\end{array}$ \\
\hline $\begin{array}{l}\text { Harvard University (Graduate School of } \\
\text { Arts and Sciences) } \\
\text { Mount Holvoke College }\end{array}$ & $\begin{array}{r}1388,590 \\
3,750\end{array}$ & 2 & $\begin{array}{r}101 \\
0\end{array}$ & $\underset{0}{2}$ & $\begin{array}{r}25 \\
6\end{array}$ & $\frac{4}{0}$ & 28 & $\begin{array}{l}18 \\
162 \\
8\end{array}$ & 159 & 3 & 160 & 2 & 160 & $\begin{array}{c}0 \\
8\end{array}$ & 2 \\
\hline $\begin{array}{l}\text { Mount Holyoke College } \\
\text { Radcliffe College. } \\
\text { Smith College. }\end{array}$ & $\begin{array}{r}3,750 \\
20,000 \\
17.000\end{array}$ & $\begin{array}{l}1 \\
3 \\
7\end{array}$ & $\begin{array}{l}0 \\
2 \\
1\end{array}$ & $\begin{array}{r}0 \\
17 \\
0\end{array}$ & $\begin{array}{r}6 \\
10 \\
5\end{array}$ & $\begin{array}{r}0 \\
5 \\
13\end{array}$ & $\begin{array}{l}1 \\
1 \\
1\end{array}$ & $\begin{array}{r}8 \\
38 \\
27\end{array}$ & $\begin{array}{l}8 \\
38 \\
27\end{array}$ & (11) $\begin{array}{r}0 \\
0\end{array}$ & $\begin{array}{r}8 \\
38 \\
27\end{array}$ & $\begin{array}{l}0 \\
0 \\
0\end{array}$ & $\begin{array}{l}0 \\
0 \\
0\end{array}$ & $\begin{array}{r}8 \\
38 \\
27\end{array}$ & $\begin{array}{l}0 \\
0 \\
0\end{array}$ \\
\hline $\begin{array}{l}\text { Infts College } \\
\text { Wellesley College- }\end{array}$ & $\begin{aligned} 41,750 \\
3,850\end{aligned}$ & $\begin{array}{l}1 \\
0\end{array}$ & $\begin{array}{l}2 \\
0\end{array}$ & $\begin{array}{l}5 \\
0\end{array} \mid$ & $\begin{array}{l}7 \\
0\end{array}$ & $\begin{array}{l}3 \\
0\end{array}$ & ${ }_{3}^{12}$ & 3 & 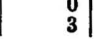 & & 3 & & & & (16) \\
\hline
\end{tabular}




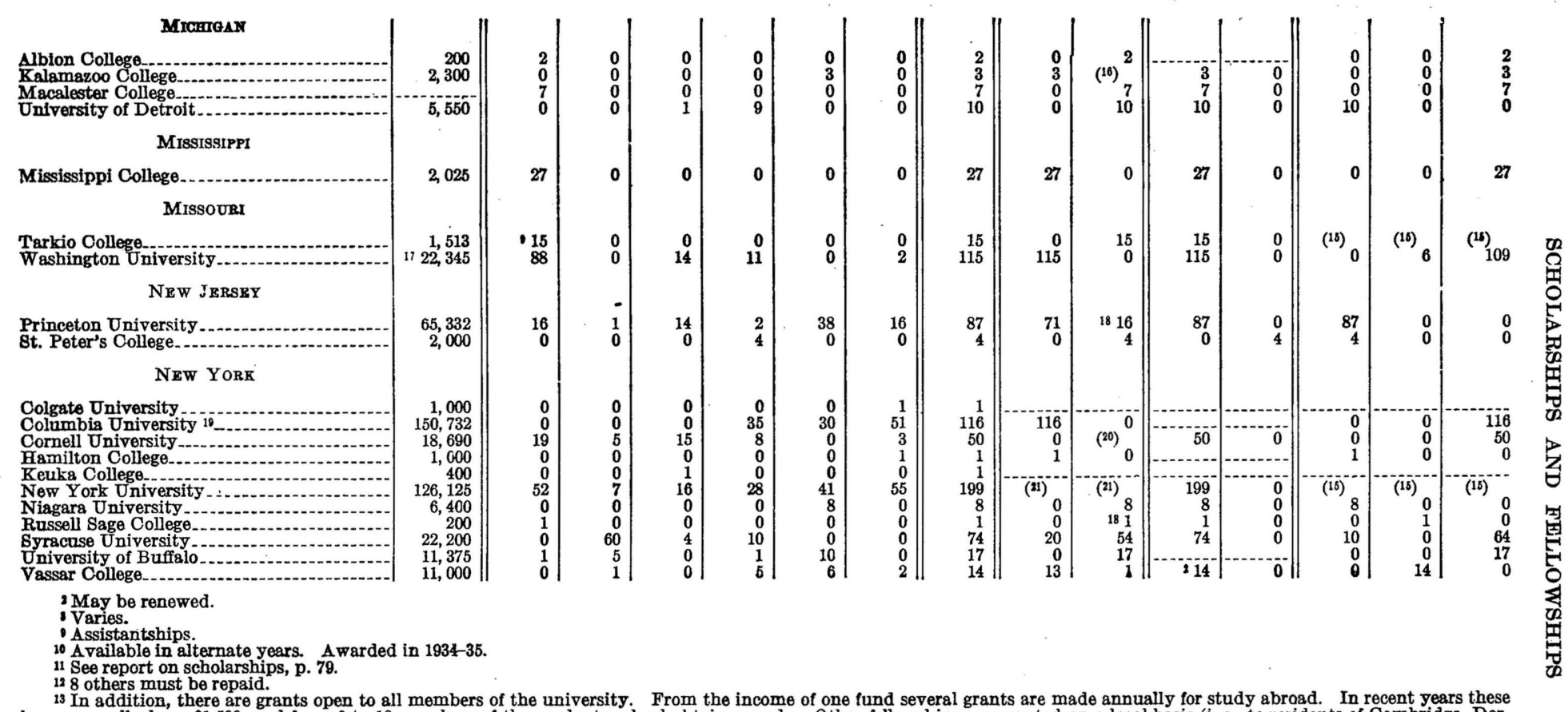

13 In addition, there are grants open to all members of the university. From the income of one fund several grants are made annually for study abroad. In recent years these
(ind chester, etc.) and are available for members of the graduate school of arts and sciences.

1" "May require 6 hours a week-seldom do."

16 One requires a small amount of help.

17 Includes fellowships and rebates.

10 Not including Bard College or Barnard College (both of which provide scholarships, but failed to report). Teachers College is listed elsewhere.

206 hours per week may be required.
$\mathbf{2 1 2 2 , 8 7 5}$ in fellowships requiring service; $\$ 3,250$ in free fellowships. 
TABLE 10.--FELLOWSHIPS AVAILABLE AT PRIVATELY SUPPORTED COLLEGES AND UNIVERSITIES, 1934-35-Contd.

\begin{tabular}{|c|c|c|c|c|c|c|c|c|c|c|c|c|c|c|c|}
\hline \multirow[b]{2}{*}{ Institution } & \multirow{2}{*}{$\mid \begin{array}{c}\text { Total } \\
\text { amount } \\
\text { availabble } \\
\text { for fel- } \\
\text { lowships }\end{array}$} & \multicolumn{6}{|c|}{ NUMBER OF FELLOWSHIPS AVAILABLE AT-- } & \multirow{2}{*}{$\begin{array}{l}\text { Total } \\
\text { num } \\
\text { bur of } \\
\text { fellow- } \\
\text { ships } \\
\text { avail- } \\
\text { able }\end{array}$} & \multirow{2}{*}{\begin{tabular}{|l} 
Num- \\
ber of \\
free \\
fellow- \\
ships
\end{tabular}} & \multirow{2}{*}{\begin{tabular}{|l} 
Num- \\
ber for \\
which \\
service \\
is re \\
quired
\end{tabular}} & \multicolumn{2}{|c|}{ 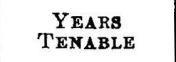 } & \multicolumn{3}{|c|}{$\begin{array}{l}\text { NUMBER A A } \\
\text { to- }-\end{array}$} \\
\hline & & $\begin{array}{l}\$ 299 \text { or } \\
\text { less }\end{array}$ & $\$ \$ \$ 300-$ & $\$ \$ \$ 490-$ & $\$ \$ \$ 749$ & $\$ \$ \$ 909$ & $\begin{array}{c}\$ 1,000 \\
\text { and } \\
\text { over }\end{array}$ & & & & One & $\begin{array}{c}\text { Two or } \\
\text { more }\end{array}$ & Men & Women & $\begin{array}{l}\text { Men } \\
\text { and } \\
\text { women }\end{array}$ \\
\hline 1 & 2 & 3 & 4 & 5 & - & 7 & 8 & o & 10 & 11 & 12 & 13 & 14 & 15 & 16 \\
\hline $\begin{array}{c}\text { NORTH CARoLnNA } \\
\text { Duke University }\end{array}$ & $\$ 26,650$ & 0 & 17 & 0 & 31 & 0 & 1 & 49 & & (27) & 49 & 0 & 0 & 0 & 49 \\
\hline $\begin{array}{l}\text { Оно } \\
\text { Cedarville College }\end{array}$ & & & & & & & & & & & & & & & \\
\hline $\begin{array}{l}\text { John Carroll University } \\
\text { Lake Erie College-............ }\end{array}$ & $\begin{array}{l}500 \\
500 \\
300\end{array}$ & $\begin{array}{r}3 \\
0\end{array}$ & 0 & $0_{0}^{-0}$ & 0 & $0_{0}^{-0}$ & 0 & 3 & 3 & 0 & 0 & 3 & 3 & $a_{0}^{-0}$ & ${ }_{0}^{0}$ \\
\hline $\begin{array}{l}\text { Ohio Wesleyan University.......... } \\
\text { St. John's University }\end{array}$ & $\begin{array}{l}36,750 \\
360\end{array}$ & 227 & $\begin{array}{c}1 \\
0\end{array}$ & $\begin{array}{c}0 \\
0 \\
0\end{array}$ & 0 & $\begin{array}{c}0 \\
0 \\
0\end{array}$ & 0 & 027 & 87 & $0^{-}$ & 27 & 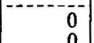 & 0 & $\begin{array}{ccc}1 \\
0 \\
0\end{array}$ & 27 \\
\hline $\begin{array}{l}\text { Western Reserve University } \\
\text { Wittenburg College. }\end{array}$ & \begin{tabular}{rl|l}
14,430 \\
8,971
\end{tabular} & $\begin{array}{rl} & 0 \\
23 & 117\end{array}$ & $\begin{array}{r}5 \\
5\end{array}$ & $\begin{array}{l}1 \\
0\end{array}$ & $\begin{array}{l}1 \\
0\end{array}$ & $\begin{array}{l}0 \\
4 \\
0\end{array}$ & $\begin{array}{l}0 \\
7 \\
0\end{array}$ & $\begin{array}{r}1 \\
18 \\
122\end{array}$ & $\begin{array}{r}18 \\
122\end{array}$ & $0_{0}^{-1}$ & $\begin{array}{l}1 \\
18 \\
46\end{array}$ & $\begin{array}{r}0 \\
0 \\
76\end{array}$ & $\begin{array}{l}1 \\
7 \\
7\end{array}$ & $\begin{array}{r}0 \\
12 \\
1\end{array}$ & $\begin{array}{r}0 \\
114\end{array}$ \\
\hline ОвLАномА & & & & & & & & & & & & & & & \\
\hline Bethany-Peniel College....... & 500 & 4 & 0 & 0 & 0 & 0 & 0 & 4 & 0 & 4 & 0 & 4 & (16) & (15) & (16) \\
\hline PENNSYLVARLA & & & & & & & & & & & & & & & \\
\hline 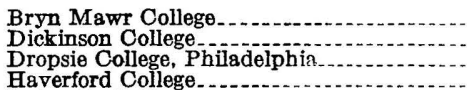 & $\begin{array}{r}30,760 \\
1,702 \\
2,000 \\
\end{array}$ & $\begin{array}{l}0 \\
0 \\
0 \\
0\end{array}$ & $\begin{array}{l}0 \\
0 \\
0 \\
0\end{array}$ & $\begin{aligned} 20 & \\
2 & \\
0 & \end{aligned}$ & $\begin{array}{l}0 \\
0 \\
4 \\
9\end{array}$ & \begin{tabular}{r|}
21 \\
1 \\
0 \\
0
\end{tabular} & $\begin{array}{l}4 \\
0 \\
0 \\
0\end{array}$ & $\begin{aligned} 45 & \\
3 & \\
4 & \\
9 & \end{aligned}$ & 3 & $\begin{array}{c}0 \\
3 \\
3\end{array}$ & $\begin{array}{r}4 \\
9 \\
9\end{array}$ & $\begin{array}{c}-1 \\
0 \\
0\end{array}$ & $\begin{array}{l}0 \\
2 \\
9 \\
9\end{array}$ & $\begin{aligned} & 45 \\
& 1 \\
& 0 \\
& 0\end{aligned}$ & $\begin{array}{l}0 \\
0 \\
0 \\
0\end{array}$ \\
\hline $\begin{array}{l}\text { Haverorda College } \\
\text { Lafayette College- }\end{array}$ & $950^{-1}$ & 0 & $\begin{array}{l}0 \\
0\end{array}$ & 1 & 1 & $\begin{array}{l}0 \\
0\end{array}$ & $\begin{array}{l}0_{0} \\
0\end{array}$ & $\begin{array}{l}y \\
2\end{array}$ & & & & & $\frac{9}{2}$ & 0 & 0 \\
\hline $\begin{array}{l}\text { Lebigh University } \\
\text { Swarthmore College.............. }\end{array}$ & $\begin{array}{r}16,920 \\
2,700 \\
037\end{array}$ & $\begin{array}{l}0 \\
0\end{array}$ & $\begin{array}{l}0 \\
0\end{array}$ & $\begin{array}{l}0 \\
0\end{array}$ & $\begin{aligned} 22 \\
5\end{aligned}$ & $\begin{array}{l}4 \\
0\end{array}$ & $\begin{array}{l}0 \\
0\end{array}$ & $\begin{array}{rl}26 & 26 \\
5 & 0\end{array}$ & $\begin{array}{r}26 \\
5\end{array}$ & $\begin{array}{l}0 \\
0\end{array}$ & $\begin{array}{r}0 \\
5 \\
7\end{array}$ & $\begin{array}{r}26 \\
0 \\
0\end{array}$ & $\begin{aligned} 26 \\
0\end{aligned}$ & $\begin{array}{l}0 \\
2 \\
0\end{array}$ & $\begin{array}{l}0 \\
3 \\
7\end{array}$ \\
\hline $\begin{array}{l}\text { University of Pittsburgh } \\
\text { Washington and Jefferson College } \\
\text { Wilson College }\end{array}$ & 1,800 & $\begin{array}{r}47 \\
6 \\
0\end{array}$ & $\begin{array}{r}r \\
0 \\
0\end{array}$ & $\begin{array}{c}0 \\
0 \\
0\end{array}$ & $\begin{array}{r}0 \\
0 \\
3\end{array}$ & $\begin{array}{c}-2 \\
0 \\
0\end{array}$ & $\begin{array}{l}2 \\
0 \\
0\end{array}$ & $\begin{array}{r}65 \\
6 \\
3\end{array}$ & $\begin{array}{l}0 \\
2 \\
0\end{array}$ & $\begin{array}{r}24 \\
24 \\
6\end{array}$ & $\begin{array}{r}51 \\
0\end{array}$ & $\begin{array}{r}14 \\
6\end{array}$ & $\begin{array}{l}6 \\
0 \\
6 \\
0\end{array}$ & $\begin{array}{l}0 \\
0 \\
0 \\
3\end{array}$ & $\begin{array}{r}6 \\
6 \\
0 \\
0\end{array}$ \\
\hline RHODE ISLAND & & & & & & & & & & & & & & & \\
\hline $\begin{array}{l}\text { Brown University } \\
\text { Pembroke College (Brown Ünivers }\end{array}$ & $\begin{aligned} 16,150 \\
2,100\end{aligned}$ & $\begin{array}{l}2 \\
0\end{array}$ & $\begin{array}{r}17 \\
0\end{array}$ & $\begin{array}{l}2 \\
1\end{array}$ & ${ }_{1}^{22}$ & $\begin{array}{l}3 \\
0\end{array}$ & $\begin{array}{l}1 \\
1\end{array}$ & $\begin{array}{r}47 \\
3\end{array}$ & 47 & 0 & 3 & 0 & $\stackrel{9}{9}$ & $\begin{array}{l}2 \\
\mathbf{3}\end{array}$ & $\begin{array}{c}36 \\
0\end{array}$ \\
\hline
\end{tabular}




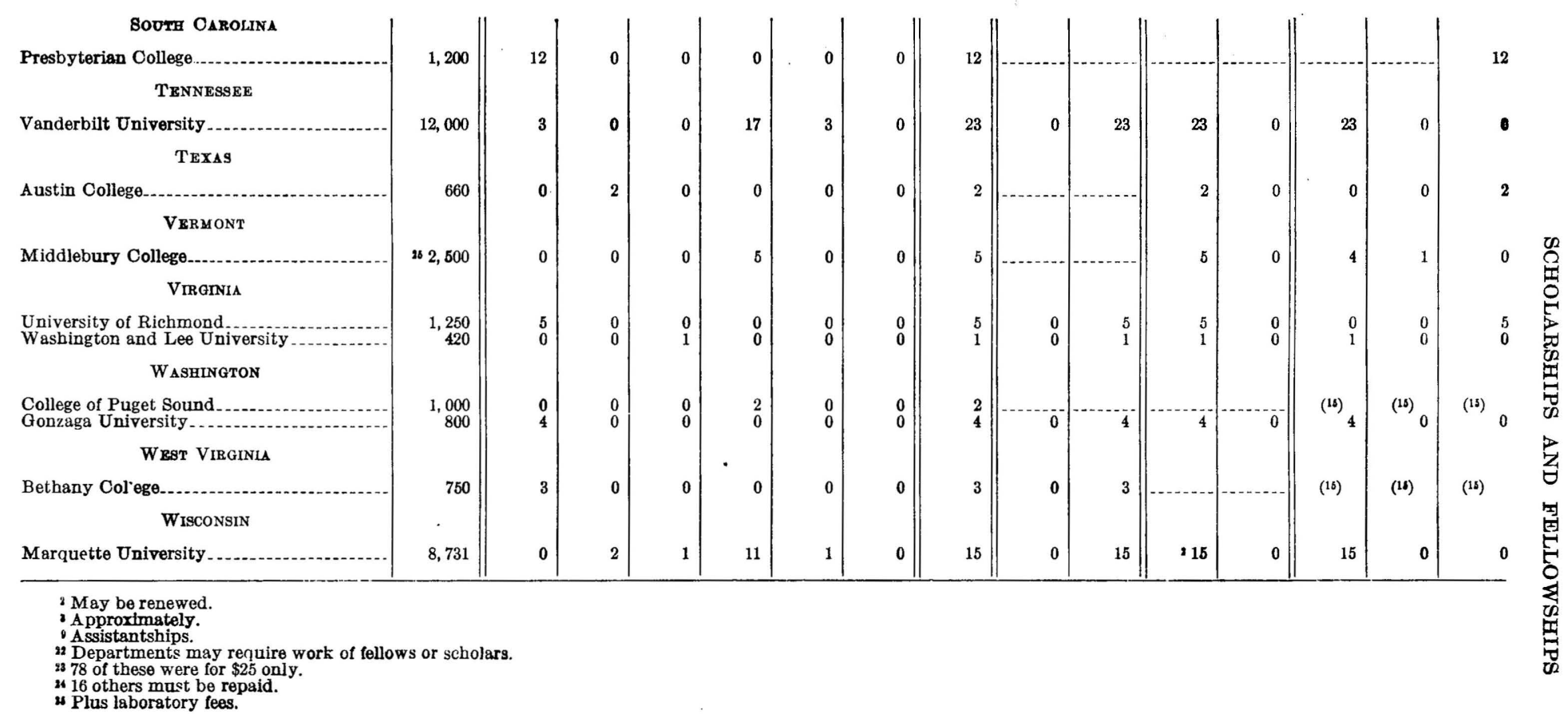


Scholarships and fellowships in the following special fields are offered by the institutions listed in the preceding tables. The number of offerings in special fields are included in the figures given in the tables. Some of the institutions did not report scholarships and fellowships for study in special fields; others indicated that they had offerings in various departments, but did not specify them. A number of institutions known to offer assistantships omitted mention of them.

\section{TABLE 11.-SCHOLARSHIPS AND FELLOWSHIPS AT PRIVATELY ENDOWED UNIVERSITIES AND COLLEGES DESIGNATED FOR STUDY IN SPECIAL FIELDS}

Administration:

George Washington University, Washington, D. C.

American literature:

Northwestern University, Evanston, Ill_..................... 1

Anatomy:

University of Chicago, Chicago, Ill

University of Buffalo, Buffalo, N. Y............

Anthropology:

Yale University, New Haven, Conn ................... ${ }^{1} 3$

Harvard University, Cambridge, Mass............ 1

Anthropology and the science of society:

Yale University, New Haven, Conn . . . .

Archaeology:

University of Chicago, Chicago, Ill........................

Johns Hopkins University, Baltimore, Md.......... . . . .......

Radcliffe College, Cambridge, Mass _............. _....... 2

Cornell University, Ithaca, N. Y.....................

Bryn Mawr College, Bryn Mawr, Pa.................... 1

Brown University, Providence, R. I.

Architecture:

Yale University, New Haven, Conn .............

Harvard University, Cambridge, Mass

Washington University, St. Louis, Mo ........... 1

Columbia University, New York, N. Y . _.........

Art:

Cornell University, Ithaca, N. Y...........................

Mills College, Mills College, Calif

Yale University, New Haven, Conn.

1 -........

Mount Holyoke College, South Hadley, Mass

Radcliffe College, Cambridge, Mass

Washington University, St. Louis, Mo

Astronomy:

Radcliffe College, Cambridge, Mass . _... 1

Princeton University, Princeton, N. J

Bacteriology:

Yale University, New Haven, Conn

\footnotetext{
i 2 may be used also for study and research in botany, zoology, geology, or geography.

i fellowships and 114 scholarships are given in the art school, including departments of painting, sculpture and architecture.
} 
Bible study:

Dropsie College, Philadelphia, $\mathrm{Pa}$

Biochemistry:

Yale University, New Haven, Conn

Boston University, Boston, Mass

Columbia University, New York, N. Y

Biology:

Northwestern University, Evanston, Il

Harvard University, Oambridge, Mass.............. 5

Radcliffe College, Cambridge, Mass

Princeton University, Princeton, N. J

Cornell University, Ithaca, N. Y.

J

University of Buffalo, Buffilo, N. Y

Bryn Mawr College, Bryn Mawr, Pa . . . . . . . . . . . . . . . .

Brown University, Providence, R. I

Vanderbilt University, Nashville, Tenn . . . . . . . . . .

Biological sciences:

Botany:

Yale University, New Haven, Conn . . . . . . . . . . . . . 3 or more

Yale University, New Haven, Conn ..................... ${ }^{4} 3$

University of Chicago, Chicago, Ill....................

Cornell University, Ithaca, N. Y . . . . . . . . . . . . .

Business administration:

Boston University, Boston, Mass....................... 10

Harvard University, Cambridge, Mass_................... 81

Columbia University, New York, N. Y . . . . . . . . . . . . . 3

Marquette University, Milwaukee, Wis........... 5

Business economics:

Johns Hopkins University, Baltimore, Md.......... 10

Chemistry:

Stanford University, Stanford University, Calif _...- 2

Yale University, New Haven, Conn ...................

George Washington University, Washington, D. C.. ........

McKendree College, Lebanon, Ill . . .

Northwestern University, Evanston, Ill...........

University of Chicago, Chicago, Ill........................

University of Notre Dame, Notre Dame, Ind........ . . . . . . .

Johns Hopkins University, Baltimore, Md.......... ..........

Amherst College, Amherst, Mass ... . . . . . . . . . . .

Harvard University, Cambridge, Mass

Mount Holyoke College, South Hadley, Mass....... . . . . . . .

Radcliffe College, Cambridge, Mass . . . . . . . . . . . . . . . . .

Kalamazoo College, Kalamazoo, Mich...................

Princeton University, Princeton, N. J...................

St. Peter's College, Jersey City, N. J.

Columbia University, New York, N. Y

Cornell University Ithaca, N. Y

Syracuse University, Syracuse, N. Y

University of Buffalo, Buffalo, N. Y

Western Reserve University, Cleveland, Ohio

1
3
A number
16
2
19
1
-2
1
1
2
4
3
3
1
20
5
1

34 fellowships may be used either in organic chemistry or biochemistry; 1 may be used either in physiological chemistry or biochemistry.

- 2 may be used also for resesrch in anthropology, zoology, geology, or geography.

$\checkmark$ Assistantships. 
Chemistry-Continued.

Scholarships

Bryn Mawr College, Bryn Mawr, Pa

Lafayette College, Easton, $\mathrm{Pa}$

Brown University, Providence, R. I.

Vanderbilt University, Nashville, Tenn

Civil engineering:

Stanford University, Stanford University, Calif ....-

Classics:

Yale University, New Haven, Conn

Harvard University, Cambridge, Mass

Princeton University, Princeton, N. J

Commerce:

Northwestern University, Evanston, Ill

University of Notre Dame, Notre Dame, Ind

Course for training advisers of girls and deans of women:

Syracuse University, Syracuse, N. Y

Dentistry:

Northwestern University, Evanston, Ill

Harvard University, Cambridge, Mass

Tufts College, Medford, Mass

Washington University, St. Louis, Mo

Marquette University, Milwaukee, Wis

Economics:

George Washington University, Washington, D. C $\ldots \ldots$

University of Chicago, Chicago, Ill .........................

Harvard University, Cambridge, Mass

Radcliffe College, Cambridge, Mass . . . . . . . . . . . . . . . . .

Tufts College, Medford, Mass . . . . . . . . . . . . . . .

Princeton University, Princeton, N. J

Columbia University, New York, N. Y

Cornell University, Ithaca, N. Y

1

1

5

2

\section{1}

32

A number A number

3

Economics and political science:

University of Chicago, Chicago, Ill

Economics and politics:

Bryn Mawr College, Bryn Mawr, Pa ................... 1

Education:

Johns Hopkins University, Baltimore, Md

2

Boston University, Boston, Mass

4

Smith College, Northampton, Mass

3

Syracuse University, Syracuse, N. Y

${ }^{5}$ Several.

Bryn Mawr College, Bryn Mawr, Pa

Electrical engineering:

Stanford University, Stanford University, Calif ...... .

2 Engineering:

Yale University, New Haven, Conn

George Washington University, Washington, D.

Northwestern University, Evanston, Ill

5

Johns Hopkins University, Baltimore, Md

Harvard University, Cambridge, Mass

Tufts College, Medford, Mass

A n u mber. 
Engineering-Continued.

Washington University, St. Louis, Mo

Scholarships Fellowships

Princeton University, Princeton, N. J

37 .......

Columbia University, New York, N. Y

Cornell University, Ithaca, N. Y.

8

Syracuse University, Syracuse, N. Y

93

Marquette University, Milwaukee, Wis

Engineering and architecture:

Washington University, St. Louis, Mo_.......... 24

English:

Yale University, New Haven, Conn

Harvard University, Cambridge, Mass.................... 1

Radcliffe College, Cambridge, Mass . . . .

Tufts College, Medford, Mass

Princeton University, Princeton, N. J.-..... 118

Columbia University, New York, N. Y

Cornell University, Ithaca, N. Y

Syracuse University, Syracuse, N. Y

Bryn Mawr College, Bryn Mawr, Pa $\ldots \ldots \ldots$

Lafayette College, Easton, $\mathrm{Pa}_{\ldots}$

Brown University, Providence, R. I.

Vanderbilt University, Nashville, Tenn _................ 6

English or history:

Mills College, Mills College, Calif ....... 2

Geography:

Yale University, New Haven, Conn

Geology:

Yale University, New Haven, Conn $\ldots$

Harva:d University, Cambridge, Mass........

Columbia University, New York, N. Y .

Cornell University, Ithaca, N. Y . .

University of Buffalo, Buffalo, N. Y

Bryn Mawr College, Bryn Mawr, Pa.................. 1

Vanderbilt University, Nashville, Tenn ..................

German:

Radcliffe College, Cambridge, Mass . . . . . . . . . . . . . . .

Bryn Mawr College, Bryn Mawr, Pa .................. 1

Government:

Harvard University, Cambridge, Mass.................. 1

Radcliffe College, Cambridge, Mass _........ 2

Government and political science:

Yale University, New Haven, Conn . . . . . . . . . . . . . . . Several.

Greek:

University of Chicago, Chicago, Ill ....................

Johns Hopkins University, Baltimore, $\mathrm{Md} \ldots \ldots \ldots$

Columbia University, New York, N. Y _._. 8

Cornell University, Ithaca, N. Y.......... 3

Bryn Mawr College, Bryn Mawr, Pa ...................... 1

Hebrew and cognate languages:

Dropsie College, Philadelphia, Pa....... 1

- Assistantships.

7 May be used also for study and research in anthropology, botany, zoology, or geology.

82 may be used also for study in anthropology, botany, zoology, or geography.

- May be used also for study in Latin. 
History:

Stanford University, Stanford University, Calif

Yale University, New Haven, Conn

Scholarships Fellowships

George Washington University, Washington, D. C.

1

University of Chicago, Chicago, Ill

Amherst College, Amherst, Mass.

Harvard University, Cambridge, Mass_........... 1

Mount Holyoke College, South Hadley, Mass..............

Radcliffe College, Cambridge, Mass

Princeton University, Princeton, N. J.

Columbia University, New York, N. Y

Cornell University, Ithaca, N. Y. 4

University of Buffalo, Buffalo, N. Y

Bryn Mawr College, Bryn Mawr, Pa

Dropsie College, Philadelphia, $\mathrm{Pa}$

Vanderbilt University, Nashville, Tenn 6

History of art:

Bryn Mawr College, Bryn Mawr, Pa.................... 1

Home economics:

Mills College, Mills College, Calif.

Cornell University, Ithaca, N. Y.

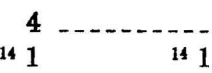

Syracuse University, Syracuse, N. Y Humanities:

University of Chicago, Chicago, Ill_....................... 1

Hygiene and bacteriology:

University of Chicago, Chicago, $\mathrm{Hl}$

Hygiene and public health:

Johns Hopkins University, Baltimore, Md

Industrial relations:

Bryn Mawr College, Bryn Mawr, Pa.................. 1 or 2

Journalism:

Yale University, New Haven, Conn _................. 1

Northwestern University, Evanston, Ill- 6

Columbia University, New York, N. Y

6

Marquette University, Milwaukee, Wis

8

Landscape architecture:

Harvard University, Cambridge, Mass_............ . . . . . . 11

Languages:

Columbia University, New York, N. Y

Bryn Mawr College, Bryn Mawr, Pa_..... 2

Latin (see also under "Greek"):

Law:

Bryn Mawr College, Bryn Mawr, $\mathrm{Pa} \ldots \ldots \ldots$

Northwestern University, Evanston, Ill

Stanford University, Stanford University, Calif

Yale University, New Haven, Conn.
A consid-

e r a b le A number number

147

- Assistantships.

10 In American history.

11 for study in history or economics; 1 may be used also for study in philosophy, philology, literature, political science, political economy, mathematics, or natural science.

12 For study in history and government.

13 In Jewish history.

14 See also p. 57. 
Law-Continued.

Amherst College, Amherst, Mass

Boston University, Boston, Mass

51

142

Harvard University, Cambridge, Mass

Fellowships

Tufts College, Medford, Mass

1614

Washington University, St. Louis, Mo.

45

Columbia University, New York, N. Y

Cornell University, Ithaca, N. Y

University of Buffalo, Buffalo, N. Y

Vanderbilt University, Nashville, Tenn

Marquette University, Milwaukee, Wis

Library service:

Columbia University, New York, N. Y

University of Chicago, Chicago, Ill .........................

Western Reserve University, Cleveland, Ohio.......

Literary, linguistic, and historical studies:

Northwestern University, Evanston, Ill ............

Literature:

Amherst College, Amherst, Mass

Radcliffe College, Cambridge, Mass . . .

Mathematical science:

Northwestern University, Evanston, IIl

Material medica:

University of Buffalo, Buffalo, N. Y thematics:

Amherst College, Amherst,

191

Harvard University, Cambridge, Mass .............

Radcliffe College, Cambridge, Mass

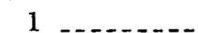

171

182

Princeton University, Princeton, N. J

2

Columbia University, New York, N. Y . .

Cornell University, Ithaca, N. Y

Syracuse University, Syracuse, N. Y

University of Buffalo, Buffalo, N. Y

Bryn Mawr College, Bryn Mawr, Pa

Vanderbilt University, Nashville, Tenn

Medicine:

Stanford University, Stanford University, Calif ....-

Yale University, New Haven, Conn . . . . . . . .

George Washington University, Washington, D. C.-

Loyola University, Chicago, Ill ..................

Northwestern University, Evanston, IIl-

Amherst College, Amherst, Mass

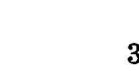

2

Boston University, Boston, Mass _..................

Harvard University, Cambridge, Mass

Tufts College, Medford, Mass

Washington University, St. Louis, Mo

1

- Assistantships.

15 For use at any school approved by the board of trustees of the college.

16 In law and diplomacy.

17 May be used also for study in philosophy, history, political science, political economy, mathematics, or natural science.

181 in English literature and 1 in comparative literature.

10 May be used also for study in philosophy, literature, history, political science, political economy, or natural science.

${ }^{0}$ For use at any school approved by the board of trustees of the college. 
Medicine-Continued.

Scholarships Fellowships

Columbia University, New York, N. Y

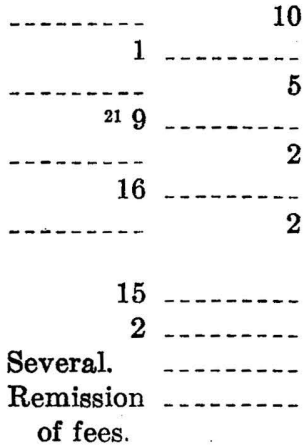

Cornell University, Ithaca, N. Y . . . . . . . . . .

Western Reserve University, Cleveland, Ohio........

Lafayette College, Easton, $\mathrm{Pa}_{\text {. }}$

University of Pittsburgh, Pittsburgh, $\mathrm{Pa}$

Vanderbilt University, Nashville, Tenn

Marquette University, Milwaukee, Wis

Ministry:

Trinity College, Hartford, Conn

George Washington University, Washington, D. C..-

Hobart College, Geneva, N. Y

Davidson College, Davidson, N. C

of fees.

Missionary service:

Northwestern University, Evanston, Ill _.......... 1

Modern languages:

Princeton University, Princeton, N. J.

Music:

Mills College, Mills College, Calif

Yale University, New Haven, Conn ............ $20 \quad 1$

Harvard University, Cambridge, Mass...................

Radcliffe College, Cambridge, Mass ...

Columbia University, New York, N. Y ...

Natural science:

Amherst College, Amherst, Mass_........................ ${ }^{22} 1$

Nursing:

Stanford University, Stanford University, Calif .....

Yale University, New Haven, Conn.

Washington University, St. Louis, Mo

Western Reserve University, Cleveland, Ohio

231

23

9

25

Organic chemistry:

Yale University, New Haven, Conn ..................

Oriental languages:

Princeton University, Princeton, N. J._._. 1

Oriental seminary:

Johns Hopkins University, Baltimore, Md......... ......... 1

Pharmacy:

University of Buffalo, Buffalo, N. Y.

Philology:

Amherst College, Amherst, Mass

Radcliffe College, Cambridge, Mass....................... 2

Philosophy:

Yale University, New Haven, Conn . . . _.

Amherst College, Amherst, Mass....... 1

" For premedical students.

22 May be used also for study in philosophy, philology, Hterature, history, political science, politica] economy, or mathematics.

" For sohool nursing.

14 4 may be used in biochemistry.

" May be used also for study in philosophy, literature, history, political science, political economy, mathematics, or natural science.

${ }^{20} 1$ in Indie philosophy and 1 in romance philology.

"May be used also for study in philosophy, literature, history, political soience, political economy, mathematics, or natural science. 
Philosophy-Continued.

Scholarships

Harvard University, Cambridge, Mass

Fellowships

Radcliffe College, Cambridge, Mass

Princeton University, Princeton, N. J

Columbia University, New York, N. Y.

Cornell University, Ithaca, N. Y.

University of Buffalo, Buffalo, N. Y

Y Y

Bryn Mawr College, Bryn Mawr, Pa

Physical science: Physics:

Yale University, New Haven, Conn .................. 1

Yale University, New Haven, Conn ................... 2

George Washington University, Washington, D. C.

Johns Hopkins University, Baltimore, Md........ _......... 1

Harvard University, Cambridge, Mass........... _...

Mount Holyoke College, South Hadley, Mass_..... _......... 1

St. Peter's College, Jersey City, N. J .

Columbia University, New York, N. Y _...... 1

Cornell University, Ithaca, N. Y

Syracuse University, Syracuse, N. Y

University of Buffalo, Buffalo, N. Y....

Bryn Mawr College, Bryn Mawr, Pa......... _...... ${ }_{28} 2$

Vanderbilt University, Nashville, Tenn $\ldots \ldots \ldots \ldots \ldots$

Physical education:

Amherst College, Amherst, Mass

Physiology:

University of Chicago, Chicago, Ill

Radcliffe College, Cambridge, Mass

University of Buffalo, Buffalo, N. Y

Political economy:

Amherst College, Amherst, Mass ...

Political science:

Northwestern University, Evanston, Ill_.............. Several.

Goucher College, Baltimore, Md....................... ${ }^{30} 1$

Johns Hopkins University, Baltimore, Md

Amherst College, Amherst, Mass

Radcliffe College, Cambridge, Mass . .

Syracuse University, Syracuse, N. Y........... . . . . . 6 Several.

Politics:

Princeton University, Princeton, N. J._................ 1

Psychiatry:

University of Buffalo, Buffalo, N. Y........... 1

Psychology:

Yale University, New Haven, Conn

George Washington University, Washington, D. C. $\ldots \ldots \ldots$

Radcliffe College, Cambridge, Mass ........................ 1

1 Assistantships.

at 1 may be used for research in chemistry.

20 May be used also for study in philosophy, literature, history, political science, mathematics, or natural science.

20 For "study and development of the subject of political education of women in the United States" Available in alternate years.

31 May be used also for study in philosophy, philology, literature, history, political economy, mathematics, or natural science.

$75014^{\circ}-36-8$ 
Psychology-Continued.

Scholarships

Princeton University, Princeton, N. J

Scholarships

Fellowships

Columbia University, New York, N. Y.

Cornell University, Ithaca, N. Y

University of Buffalo, Buffalo, N. Y

Bryn Mawr College, Bryn Mawr, Pa......................

Public affairs:

Syracuse University, Syracuse, N. Y

${ }^{5}$ Several.

Rabbinical study:

Dropsie College, Philadelphia, $\mathrm{Pa}$

Romance languages:

Johns Hopkins University, Baltimore, Md...................

Radcliffe College, Cambridge, Mass . . .

Cornell University, Ithaca, N. Y._...........

Religion and missions:

Yale University, New Haven, Conn ......... 1

Semitics:

Yale University, New Haven, Conn ............. . . 1

Social science:

Northwestern University, Evanston, Ill..........

Amherst College, Amherst, Mass.

Columbia University, New York, N. Y....................

Social service administration:

University of Chicago, Chicago, Ill

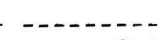

Social economy and social research:

Bryn Mawr College, Bryn Mawr, Pa

Social work:

Loyola University, Chicago, Ill.

4 or 5

Washington University, St. Louis,

5

Sociology:

University of Chicago, Chicago, Ill ...........................

Harvard University, Cambridge, Mass

Radcliffe College, Cambridge, Mass . . . . .

University of Buffalo, Buffalo, N. Y...................

Western Reserve University, Cleveland, Ohio...... _........ 6

Vanderbilt University, Nashville, Tenn .................... 1

Theology:

Yale University, New Haven, Conn $\ldots 161$

University of Chicago, Chicago, Ill_..._._. 11

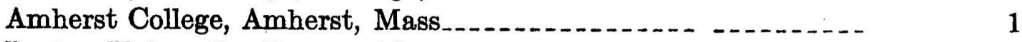

Boston University, Boston, Mass_..._....... 49

Harvard University, Cambridge, Mass

Vanderbilt University, Nashville, Tenn

Zoology:

Yale University, New Haven, Conn..................... 3 or more.

Johns Hopkins University, Baltimore, Md.............. 2

Noтв.-See also scholarships and fellowships available at independent privately endowed technical and professional schools, tables 13 and 14, pages 110 and 114, and those given by State-supported technical schools, tables 2 and 3 , pages 44 and 52.

- Assistantships.

"For the study of social, economic, and political institutions. 
TABL 12.-SCHOLARSHIPS AND FELLOWSHIPS AVAILABLE AT PRIVATELY SUPPORTED TEACHERS COLLEGES AND NORMAL SCHOOLS, 1934-35

\begin{tabular}{|c|c|c|c|c|c|c|c|c|c|c|c|c|c|c|c|c|c|}
\hline \multirow{2}{*}{ Institution and location } & \multirow{2}{*}{$\begin{array}{c}\text { Total } \\
\text { amount } \\
\text { available } \\
\text { for schol- } \\
\text { arships } \\
\text { and fel- } \\
\text { lowships }\end{array}$} & \multicolumn{8}{|c|}{$\underset{\text { NUMBER OF SCHOLARSHIPS AND FrLLOWSHIPS }}{\text { AVAILABLE AT- }}$} & \multirow{2}{*}{\begin{tabular}{|c|} 
Total \\
number \\
of schol- \\
arships \\
and fel- \\
low- \\
ships \\
avail- \\
able
\end{tabular}} & \multirow{2}{*}{$\begin{array}{c}\text { Num- } \\
\text { ber } \\
\text { free }\end{array}$} & \multirow{2}{*}{$\begin{array}{l}\text { Num- } \\
\text { ber for } \\
\text { which } \\
\text { service } \\
\text { is re- } \\
\text { quired }\end{array}$} & \multicolumn{2}{|c|}{$\begin{array}{l}\text { YEARS } \\
\text { TENABLE }\end{array}$} & \multicolumn{3}{|c|}{$\underset{\text { TO- }}{\text { NUMBER AVAILABLE }}$} \\
\hline & & $\begin{array}{c}\text { Less } \\
\text { than } \\
\$ 50\end{array}$ & $\$ 50-$ & $\$ \$ \$ 100-$ & $\$ \$ \$ 150-$ & $\begin{array}{l}\$ 200- \\
\$ 249\end{array}$ & $\$ \$ \$ 250-$ & $\$ \$ 300-$ & $\begin{array}{l}\text { Over } \\
\$ 350\end{array}$ & & & & One & $\begin{array}{c}\text { Two to } \\
\text { four }\end{array}$ & Men & Women & $\begin{array}{l}\text { Men } \\
\text { and } \\
\text { women }\end{array}$ \\
\hline $\mathbf{1}$ & 2 & 3 & 4 & 5 & 6 & 7 & 8 & $\theta$ & 10 & 11 & 12 & 13 & 14 & 15 & 16 & 17 & 18 \\
\hline $\begin{array}{l}\text { Arnold College, New Haven, Conn } \\
\text { Concordia Teachers College, River Forest, Iil- } \\
\text { National College of Education, Evanston, Il- } \\
\text { Pestalozzi Froebel Teachers College, Chicago, } \\
\text { Normal College of American Gymnastic Union, } \\
\text { Indianapolis, Ind }\end{array}$ & $\begin{array}{r}\$ 2,400 \\
125 \\
9,237 \\
4,500\end{array}$ & $\begin{array}{l}0 \\
2 \\
0 \\
0 \\
0\end{array}$ & $\begin{array}{r}0 \\
1 \\
3 \\
0 \\
14\end{array}$ & $\begin{array}{r}24 \\
0 \\
12 \\
0 \\
8\end{array}$ & $\begin{array}{r}0 \\
0 \\
4 \\
5-10 \\
0\end{array}$ & $\begin{array}{l}0 \\
0 \\
6 \\
0 \\
0\end{array}$ & $\begin{array}{l}0 \\
0 \\
0 \\
0 \\
\end{array}$ & $\begin{array}{r}0 \\
0 \\
20 \\
5-10 \\
\end{array}$ & $\begin{array}{l}0 \\
0 \\
0 \\
0\end{array}$ & $\begin{array}{r}24 \\
3 \\
45 \\
16-20 \\
20\end{array}$ & $\begin{array}{r}3 \\
22\end{array}$ & 110 & $\begin{array}{r}0 \\
-45 \\
10-20\end{array}$ & \begin{tabular}{c|c}
24 \\
$-2-$ \\
0 \\
0
\end{tabular} & $\begin{array}{l}0 \\
3 \\
0 \\
0\end{array}$ & $\begin{array}{r}0 \\
0 \\
45 \\
10-20\end{array}$ & $\begin{array}{r}24 \\
0 \\
0 \\
0\end{array}$ \\
\hline $\begin{array}{l}\text { Indianapolis, Ind } \\
\text { Progressive Series Teachers College, St. Louis, Mo- } \\
\text { Panzer College of Physical Education, East } \\
\text { Orange, N. J. }\end{array}$ & $\begin{array}{r}3,640 \\
4,741 \\
400\end{array}$ & $\begin{array}{l}0 \\
0\end{array}$ & $\begin{array}{r}14 \\
0\end{array}$ & $\begin{array}{r}8 \\
40\end{array}$ & $\begin{array}{l}0 \\
0\end{array}$ & $\begin{array}{r}10 \\
0\end{array}$ & $\begin{array}{l}0 \\
0\end{array}$ & $\begin{array}{l}0 \\
0\end{array}$ & $\begin{array}{l}0 \\
0\end{array}$ & $\begin{array}{l}32 \\
40\end{array}$ & $\begin{array}{l}32 \\
40\end{array}$ & $\begin{array}{l}0 \\
0 \\
0\end{array}$ & 13 & 27 & 0 & 0 & 40 \\
\hline $\begin{array}{l}\text { Child Educeation Foundation, New York, N. } \\
\text { Flatbush Teacher-Training School, Brooklyn, } \\
\text { N. Y }\end{array}$ & $\begin{array}{l}2,375 \\
1,800\end{array}$ & 0 & $\theta$ & 0 & 0 & 0 & 0 & 2 & 2 & $\begin{array}{l}4 \\
4\end{array}$ & $\begin{array}{ll}8 & 1 \\
3 & 3 \\
8 & 6\end{array}$ & $\begin{array}{r}34 \\
3 \\
0\end{array}$ & $\begin{array}{l}4 \\
0 \\
0\end{array}$ & $\begin{array}{l}0 \\
4 \\
9\end{array}$ & $\begin{array}{l}0 \\
0 \\
0\end{array}$ & $\begin{array}{l}0 \\
4 \\
9\end{array}$ & ${ }_{0}^{4}$ \\
\hline $\begin{array}{l}\text { Harriette Melissa Mills Training School, New } \\
\text { York, N. Y } \\
\text { osavage School of Physical Education, New York, }\end{array}$ & 200 & $\mathbf{0}$ & 0 & 2 & 0 & 0 & 0 & 0 & 0 & 2 & & & & & & 2 & 0 \\
\hline $\begin{array}{l}\text { N. Y.. } \\
\text { Neachers College (Columbia University), New }\end{array}$ & B 2,050 & 0 & 17 & 1 & 0 & 0 & 0 & 0 & 1 & 019 & 19 & 0 & 19 & 0 & 0 & 0 & 19 \\
\hline $\begin{array}{l}\text { York, N. Y } \\
\text { Toledo Teachers College, Toledo, Ohio } \\
\text { Ilman Training School, Philadelphia, Pa. }\end{array}$ & $\begin{array}{r}736,840 \\
1,090 \\
260\end{array}$ & $\begin{array}{r}64 \\
0 \\
0\end{array}$ & $\begin{array}{r}16 \\
2 \\
0\end{array}$ & $\begin{array}{r}20 \\
6 \\
0\end{array}$ & $\begin{array}{r}44 \\
0 \\
0\end{array}$ & $\begin{array}{r}17 \\
0 \\
0\end{array}$ & $\begin{array}{l}9 \\
1 \\
1\end{array}$ & $\begin{array}{r}37 \\
0 \\
0\end{array}$ & $\begin{array}{r}17 \\
0 \\
0\end{array}$ & $\begin{array}{r}r 224 \\
9 \\
1\end{array}$ & 223 & 1 & $\begin{array}{r}224 \\
0 \\
1\end{array}$ & $\begin{array}{l}0 \\
9 \\
0\end{array}$ & $\begin{array}{l}1 \\
0 \\
0\end{array}$ & \begin{tabular}{l|}
1 \\
0 \\
1
\end{tabular} & $\begin{array}{r}222 \\
9 \\
0\end{array}$ \\
\hline
\end{tabular}

112 others must be repaid.

Exchange stadent.

?1 other carries a moral obligation to be repaid.

2 scholarships are limited to instruction in dancing: 1 at $\$ 100,1$ at $\$ 1,010$

$7 \$ 10,550$ is for fellowships, distributed as follows: 2 at $\$ 0-\$ 299 ; 11$ at $\$ 300-\$ 399 ; 2$ at $\$ 400-\$ 499 ; 10$ at $\$ 500-\$ \bar{r}$ is $; 1$ at $\$ 750-\$ 999$. In addition to scholarships a nd fellowships, the college granted (in 1934-35) free tuition to 198 staff members, totaling $\$ 11,045 ; 843$ tuition allowances in its elementary and secondary schools, totaling $\$ 153,854$; and loans to stadents totaling approximately $\$ 40,000$. 
TABLE 13.-SCHOLARSHIPS AVAILABLE AT INDEPENDENT PRIVATELY ENDOWED TECHNICAL AND

PROFESSIONAL SCHOOLS, 1934-35

ART SOHOOLS

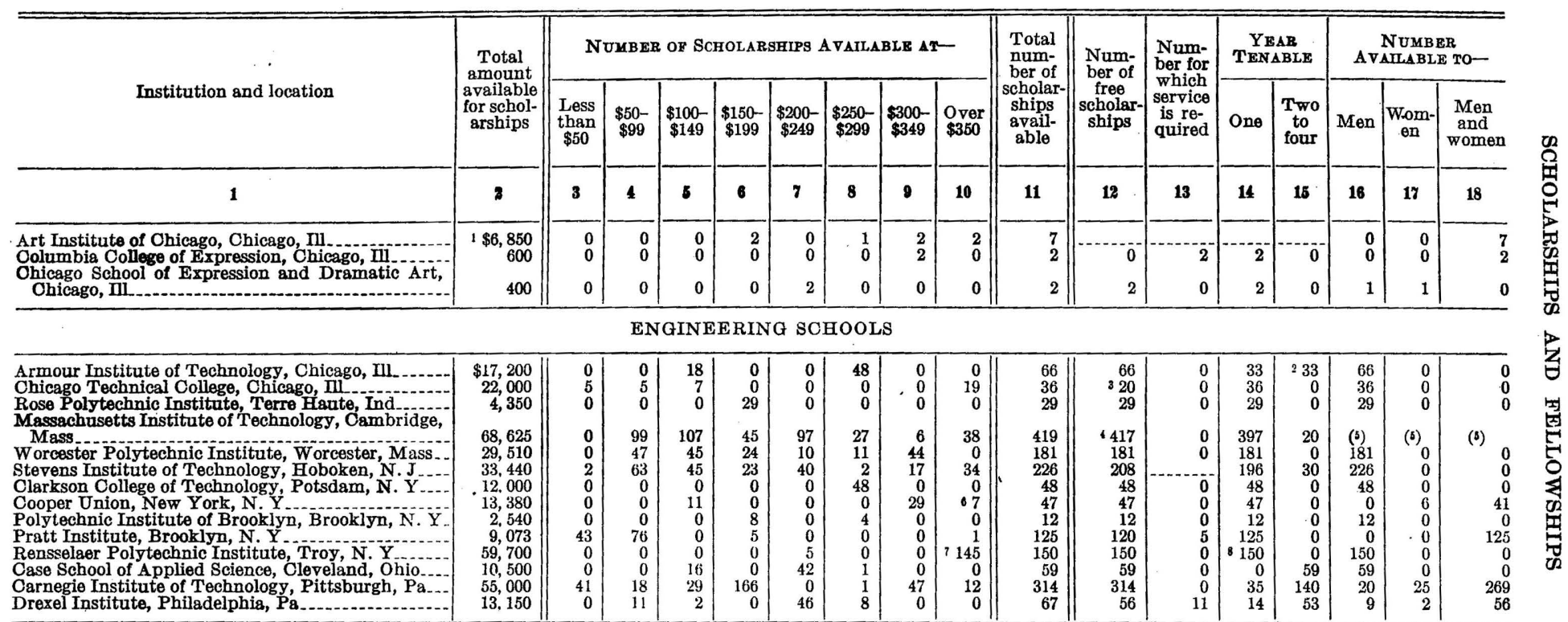

LAW SCHOOLS

\begin{tabular}{|c|c|c|c|c|c|c|c|c|c|c|c|c|c|c|c|c|c|}
\hline $\begin{array}{l}\text { The American University, Las Angeles, Calif..... } \\
\text { Indiana Law School, Indianapolis, Ind -.. } \\
\text { Y.M. O. A. Night Law School, Oincinnati, Ohio.- } \\
\text { John Randolph Neal College of Law, Knaxville, } \\
\text { Tenn }\end{array}$ & $\begin{array}{r}\$ 600 \\
75 \\
500\end{array}$ & $\begin{array}{l}0 \\
2 \\
0 \\
0\end{array}$ & $\begin{array}{r}0 \\
0 \\
8 \\
5-10\end{array}$ & $\begin{array}{l}0 \\
0 \\
0\end{array}$ & $\begin{array}{l}0 \\
0 \\
0\end{array}$ & $\begin{array}{l}3 \\
0 \\
0\end{array}$ & $\begin{array}{l}0 \\
0 \\
0\end{array}$ & $\begin{array}{l}0 \\
0 \\
0\end{array}$ & $\begin{array}{r}3 \\
0 \\
0\end{array}$ & $\begin{array}{r}2 \\
8 \\
5-10\end{array}$ & 2 & 0 & $5-10$ & 0 & $\begin{array}{l}2 \\
0 \\
0 \\
0\end{array}$ & $\begin{array}{l}1 \\
0 \\
0 \\
0\end{array}$ & $\begin{array}{r}0 \\
2 \\
8 \\
5-10\end{array}$ \\
\hline
\end{tabular}


MEDICAL SCHOOLS

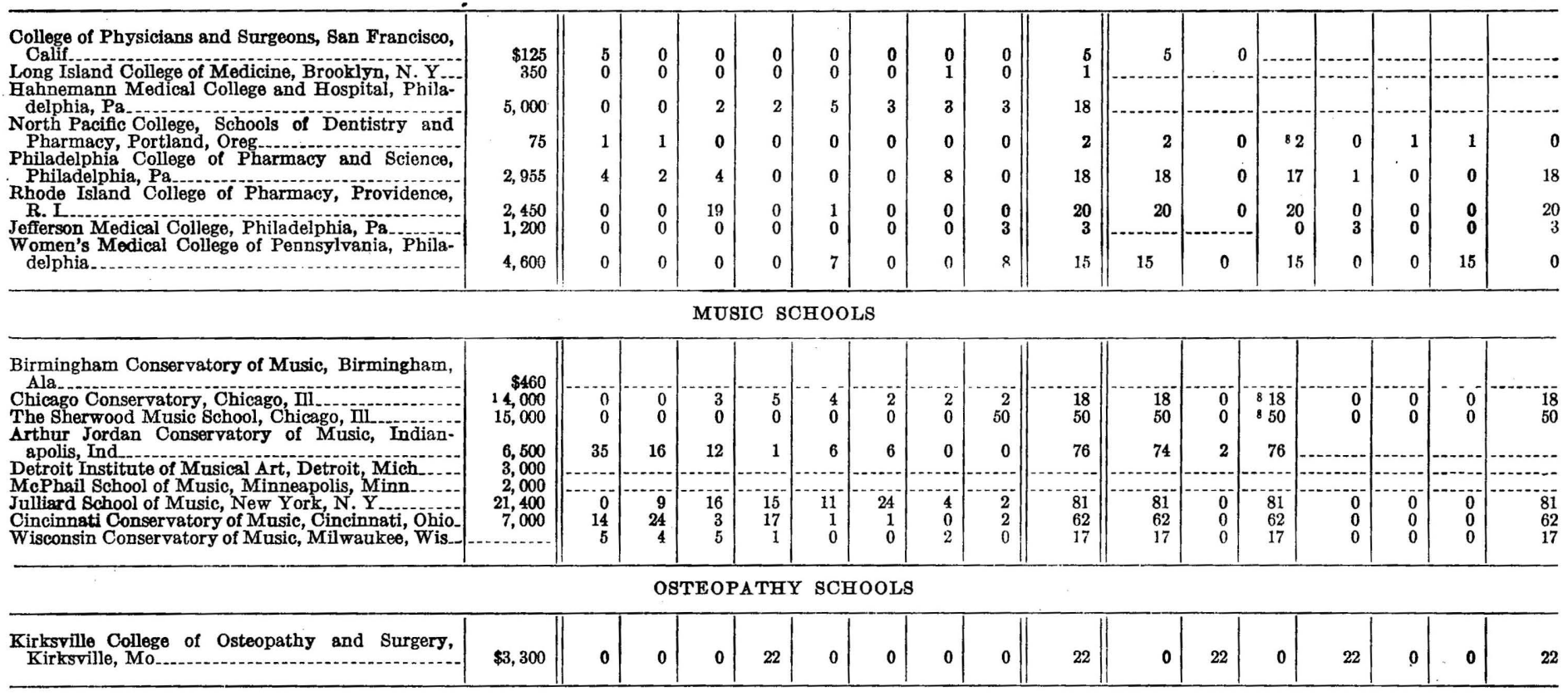

Approximately.

In the department of fire-protection engineering.

316 others carry a moral obligation to be repaid.

2 others carry a moral obligation to be repaid.

i Number not reported. $\$ 1,250,4$ for $\$ 480$, and 1 for $\$ 460$.

141 cover tuition of $\$ 400 ; 4$ cover tuition plus living quarters estimated at $\$ 175$ annually.

5 must be repaid. 
TABLE 13.-SCHOLARSHIPS AVAILABLE AT INDEPENDENT PRIVATELY ENDOWED TECHNICAL AND PROFESSIONAL SCHOOLS, 1934-35-Continued

PHARMACY SCHOOLS

\begin{tabular}{|c|c|c|c|c|c|c|c|c|c|c|c|c|c|c|c|c|c|}
\hline \multirow{2}{*}{ Institution and location } & \multirow{2}{*}{\begin{tabular}{|} 
Total \\
amount \\
available \\
for schol- \\
arships
\end{tabular}} & \multicolumn{8}{|c|}{ NUMBER OF SCHOLARSHIPS AVAILABLE AT— } & \multirow{2}{*}{$\begin{array}{c}\text { Total } \\
\text { num- } \\
\text { ber of } \\
\text { scholar- } \\
\text { ships } \\
\text { avail- } \\
\text { able }\end{array}$} & \multirow{2}{*}{$\begin{array}{c}\text { Num- } \\
\text { ber of } \\
\text { free } \\
\text { scholar- } \\
\text { ships }\end{array}$} & \multirow{2}{*}{$\begin{array}{l}\text { Num- } \\
\text { ber for } \\
\text { which } \\
\text { service } \\
\text { is re- } \\
\text { quired }\end{array}$} & \multicolumn{2}{|c|}{$\underset{\text { TENABLE }}{\text { YEAR }}$} & \multicolumn{3}{|c|}{$\begin{array}{l}\text { NUMBER } \\
\text { AVAILABLE TO- }\end{array}$} \\
\hline & & $\begin{array}{c}\text { Less } \\
\text { than } \\
\$ 50\end{array}$ & $\$ 50-$ & $\begin{array}{l}\$ 100- \\
\$ 149\end{array}$ & $\begin{array}{l}\$ 150- \\
\$ 199\end{array}$ & $\$ \$ 200-$ & $\$ 250-$ & $\begin{array}{c}\$ 300- \\
\$ 349\end{array}$ & $\begin{array}{l}\text { Over } \\
\$ 350\end{array}$ & & & & One & $\begin{array}{l}\text { Two } \\
\text { to } \\
\text { four }\end{array}$ & Men & Wom- & $\begin{array}{l}\text { Men } \\
\text { and } \\
\text { women }\end{array}$ \\
\hline 1 & 2 & 3 & 4 & 5 & 6 & $\boldsymbol{7}$ & 8 & 9 & 10 & 11 & 12 & 13 & 14 & 15 & 16 & 17 & 18 \\
\hline $\begin{array}{l}\text { Connecticut College of Pharmacy, New Haven, } \\
\text { Conn } \\
\text { Louisvilie College of Pharmacy, Louisvile, Ky } \\
\text { Massachusetts College of Pharmacy, Boston, Mass.-. } \\
\text { St. Louis College of Pharmacy, St. Louis, Mo }\end{array}$ & $\begin{array}{r}\$ 1,150 \\
150 \\
1,280 \\
1,000\end{array}$ & $\begin{array}{l}0 \\
0 \\
2 \\
0\end{array}$ & $\begin{array}{l}0 \\
0 \\
9 \\
0\end{array}$ & $\begin{array}{l}0 \\
1 \\
0 \\
0\end{array}$ & $\begin{array}{l}0 \\
0 \\
3 \\
0\end{array}$ & $\begin{array}{l}5 \\
0 \\
1 \\
5\end{array}$ & $\begin{array}{l}0 \\
0 \\
0 \\
0\end{array}$ & $\begin{array}{l}0 \\
0 \\
0 \\
0\end{array}$ & $\begin{array}{l}0 \\
0 \\
0 \\
0\end{array}$ & $\begin{array}{r}5 \\
1 \\
015 \\
5\end{array}$ & $\begin{array}{r}5 \\
1 \\
10 \\
5\end{array}$ & $\begin{array}{l}0 \\
0 \\
0 \\
0\end{array}$ & $\begin{array}{r}5 \\
0 \\
10 \\
5\end{array}$ & $\begin{array}{c}0 \\
-5 \\
0\end{array}$ & $\begin{array}{l}0 \\
0 \\
0 \\
0\end{array}$ & $\begin{array}{l}0 \\
0 \\
0 \\
0\end{array}$ & $\begin{array}{r}5 \\
1 \\
15 \\
5\end{array}$ \\
\hline \multicolumn{18}{|c|}{ SCHOOL OF SOCIAL WORK } \\
\hline $\begin{array}{l}\text { Graduate School for Jewish Social Work, New } \\
\text { York, N. Y }\end{array}$ & $\$ 3,000$ & 0 & 0 & 0 & 16 & $\mathbf{0}$ & 10 & 0 & 0 & 26 & 26 & 0 & 26 & 0 & 0 & 0 & 26 \\
\hline \multicolumn{18}{|c|}{ THEOLOGICAL SCHOOLS } \\
\hline $\begin{array}{l}\text { Berkeley Baptist Divinity School, Berkeley, Calif-- } \\
\text { Church Divinity School of the Pacific, Berkeley, } \\
\text { Calif }\end{array}$ & $\$ 6,000$ & $\begin{array}{l}0 \\
0\end{array}$ & 2 & 17 & 0 & 0 & 0 & 0 & 0 & 19 & & & 0 & 3 & $\left({ }^{(0)}\right.$ & $(s)$ & (5) \\
\hline $\begin{array}{l}\text { Pacific School of Religion, Berkeley, Calif } \\
\text { San Francisco Theological Seminary, San Anselmo, } \\
\text { Calif. }\end{array}$ & 2,500 & $\begin{array}{l}0 \\
0 \\
0\end{array}$ & $\begin{array}{r}0 \\
16 \\
36\end{array}$ & $\begin{array}{l}0 \\
1 \\
0\end{array}$ & $\left.\begin{array}{r}0 \\
29 \\
0\end{array}\right]$ & $\begin{array}{l}0 \\
0 \\
0\end{array}$ & $\begin{array}{l}8 \\
0 \\
0\end{array}$ & $\begin{array}{l}0 \\
1 \\
0\end{array}$ & $\begin{array}{l}0 \\
0 \\
0\end{array}$ & $\begin{array}{r}8 \\
47 \\
36\end{array}$ & $\begin{array}{r}8 \\
32 \\
0\end{array}$ & $\begin{array}{r}0 \\
15 \\
36\end{array}$ & $\begin{array}{r}0 \\
0 \\
36\end{array}$ & $\begin{array}{r}8 \\
15 \\
0\end{array}$ & $\begin{array}{r}8 \\
0 \\
36\end{array}$ & $\begin{array}{l}0 \\
0 \\
0\end{array}$ & $\begin{array}{r}0 \\
15\end{array}$ \\
\hline $\begin{array}{l}\text { nliff School of Theology, Denver, Colo } \\
\text { Berkeley Divinity School, New Haven, Conn } \\
\text { Columbia Theological Seminary, Decatur, Ga } \\
\text { Bethany Biblical Seminary, Chicago, Ill-. Chicago, } \\
\text { Chicago Lutheran Theological Seminary; Chical }\end{array}$ & $\begin{array}{l}2,160 \\
1,000 \\
3,700 \\
3,750 \\
1,300\end{array}$ & $\begin{array}{l}0 \\
8 \\
0 \\
0 \\
3\end{array}$ & $\begin{array}{r}36 \\
0 \\
0 \\
0 \\
0\end{array}$ & $\begin{array}{r}0 \\
0 \\
4 \\
0 \\
12\end{array}$ & $\begin{array}{r}0 \\
4 \\
0 \\
25 \\
0\end{array}$ & $\begin{array}{l}0 \\
0 \\
7 \\
0 \\
0\end{array}$ & $\begin{array}{l}0 \\
0 \\
2 \\
0 \\
0\end{array}$ & $\begin{array}{l}0 \\
0 \\
1 \\
0 \\
0\end{array}$ & \begin{tabular}{l||}
0 \\
0 \\
1 \\
0 \\
0
\end{tabular} & $\begin{array}{l}36 \\
12 \\
15 \\
25 \\
15\end{array}$ & $\begin{array}{r}0 \\
12 \\
0 \\
0\end{array}$ & $\begin{array}{r}36 \\
0 \\
15 \\
1023\end{array}$ & $\begin{array}{l}36 \\
12 \\
15 \\
25\end{array}$ & $\begin{array}{r}0 \\
0 \\
0 \\
0 \\
15\end{array}$ & $\begin{array}{r}36 \\
0 \\
15 \\
25 \\
11\end{array}$ & $\begin{array}{l}0 \\
0 \\
0 \\
0 \\
4\end{array}$ & $\begin{array}{r}0 \\
12 \\
15 \\
0 \\
0\end{array}$ \\
\hline Chicago Lutheran Theological Seminary; Chicago, & 1, & & & & & & & & & & & 18 & 818 & 0 & 18 & 0 & 0 \\
\hline $\begin{array}{l}\text { Presbyterian Theological Seminary, Chicago, Ill..- } \\
\text { Seabury-Western Theological Seminary, Evanston, } \\
\text { III }\end{array}$ & 12,50 & 0 & 0 & 125 & 0 & 0 & 0 & 0 & 0 & 125 & 125 & 0 & 125 & 0 & 125 & 0 & 0 \\
\hline Wartburg Theological Seminary, Dubuque, Iowa- & 408 & $\begin{array}{l}0 \\
9\end{array}$ & \begin{tabular}{l|l}
0 \\
6
\end{tabular} & $\begin{array}{l}0 \\
0\end{array}$ & $\begin{array}{l}1 \\
0\end{array}$ & \begin{tabular}{l|l}
0 \\
0
\end{tabular} & $\begin{array}{l}0 \\
0\end{array}$ & $\begin{array}{r}34 \\
0\end{array}$ & $\begin{array}{l}0 \\
0\end{array}$ & $\begin{array}{l}35 \\
15\end{array}$ & $\begin{array}{l}32 \\
15\end{array}$ & $\begin{array}{l}3 \\
0\end{array}$ & 35 & 0 & $\begin{array}{l}35 \\
15\end{array}$ & $\begin{array}{l}0 \\
0\end{array}$ & 0 \\
\hline
\end{tabular}


Louisville Presbyterian Theological Seminary, Southern Baptist Theological Seminary, Louisville, $\mathrm{Ky}$
Westminster Theological Seminary, Westminster,

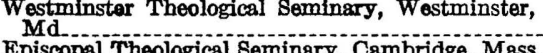
Suomit College and Theological Seminary, Hancock,

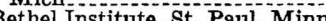

Ber Bloomfield College and Theological Seminary, Drew Theological Seminary, Madison, N. New Brunswick Theological Seminary, New Burn wick, N. J.................................... Princeton Theological Seminary, Princeton, N. J... Aiburn Theological Seminary, Auburn, N.

Colgate-Rochester D i vinity School Rochester, N.Y

General Theological Seminary of the Protestant Chicago Theological Seminary, Chicago, $\mathrm{Ml}$ Jewish Theological Seminary of America, New York, N. Y . Union Theological Seminary, New York, N. YBonebrake Theological Seminary, Dayton,

Crozer Theological Seminary, phia, $\mathrm{Pa}$. Latheran Theological Seminary, Gettysburg, $\mathrm{Pa}$ Lutheran Theological Seminary, Mount Airy, Pa-burgh, Pa $\mathrm{Pani}$ Theological Seminary, Austin Presbyterian Theological Seminary, Austin, Tex Protestant Episcopal Theo Union Theological Seminary, Richmond, Va........
St. Francis Seminary, St. Francis, Wis............

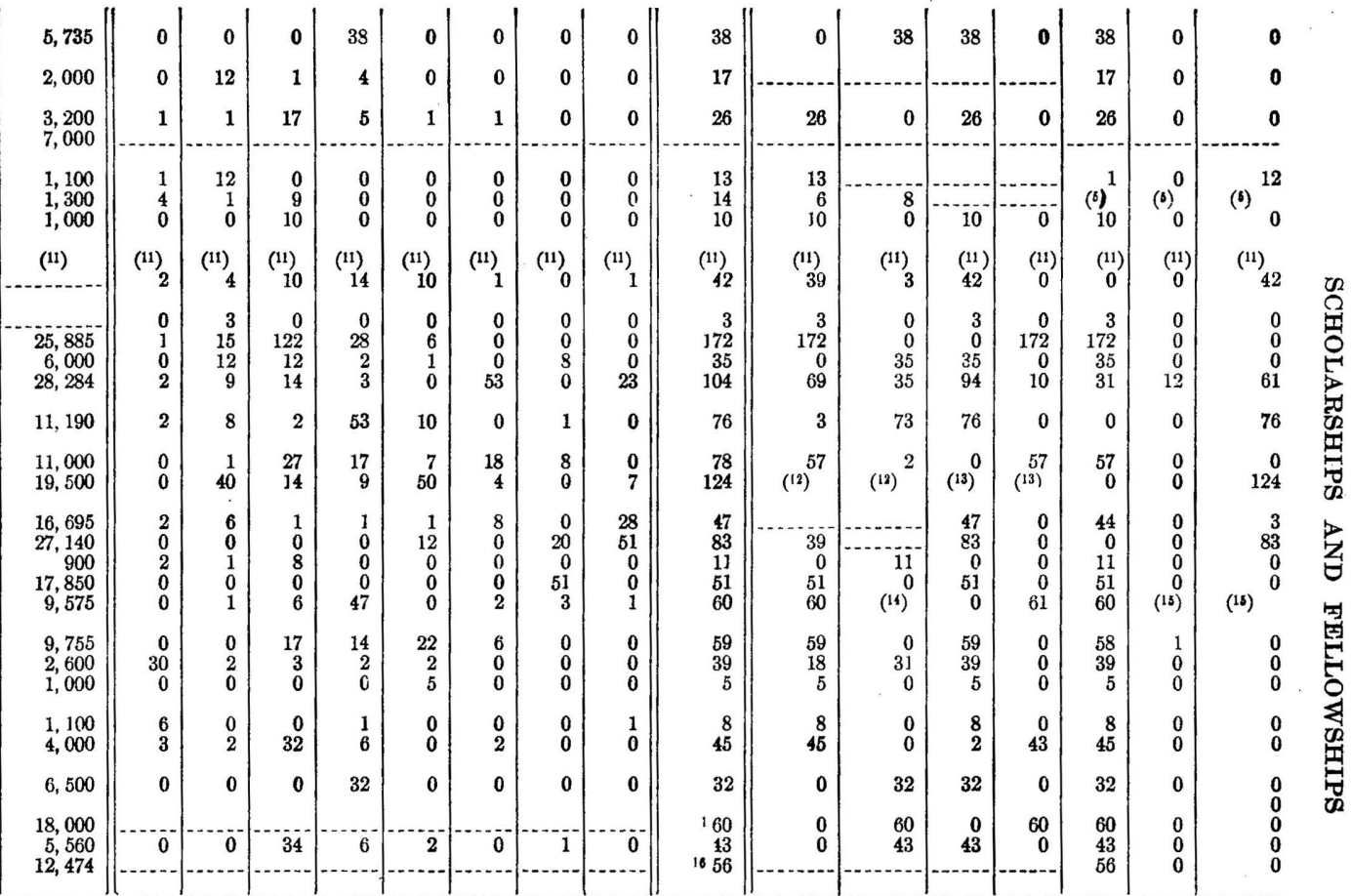

1 Approximately - Number not reported.

10 May be renewed.

11 Tuition free; granted to 72 students in 1934-35.
12 Scholarships to the amount of $\$ 16,000$ require service of holders.

14 Most scholarships are given for 1 year; a fow are for 2 and a few for 3 years

is

16 Grants mado in 1933-34. 
TABLE 14.-FELLOWSHIPS AND GRADUATE SCHOLARSHIPS AVAILABLE AT INDEPENDENT PRIVATELY ENDOWED TECHNICAL AND PROFESSIONAL SCHOOLS, 1934-35

ART SOHOOL

\begin{tabular}{|c|c|c|c|c|c|c|c|c|c|c|c|c|c|c|c|}
\hline \multirow[b]{2}{*}{ Institution . } & \multirow{2}{*}{$\begin{array}{c}\text { Total } \\
\text { amount } \\
\text { available } \\
\text { forfellow- } \\
\text { ships }\end{array}$} & \multicolumn{6}{|c|}{ NUMBER OF FELLOWSHIPS AVATLABLE $\triangle T-$} & \multirow{2}{*}{\begin{tabular}{|c|} 
Total \\
number \\
of \\
fellow- \\
ships \\
avail- \\
able
\end{tabular}} & \multirow{2}{*}{$\begin{array}{l}\text { Num- } \\
\text { ber of } \\
\text { free } \\
\text { fellow- } \\
\text { ships }\end{array}$} & \multirow{2}{*}{$\begin{array}{l}\text { Num- } \\
\text { ber for } \\
\text { which } \\
\text { service } \\
\text { is re- } \\
\text { quired }\end{array}$} & \multicolumn{2}{|c|}{ YEARSTENABLE } & \multicolumn{3}{|c|}{ NUMBER A VAILABLE TO- } \\
\hline & & $\begin{array}{c}\$ 299 \\
\text { or less }\end{array}$ & $\$ 300-$ & $\$ 400-$ & $\$ \$ 500-$ & $\begin{array}{l}\$ 750- \\
\$ 999\end{array}$ & $\begin{array}{l}\$ 1,000 \\
\text { and } \\
\text { over }\end{array}$ & & & & One & $\begin{array}{c}\text { Two or } \\
\text { more }\end{array}$ & Men & $\begin{array}{c}\text { Wom- } \\
\text { en }\end{array}$ & $\begin{array}{c}\text { Men } \\
\text { and } \\
\text { women }\end{array}$ \\
\hline 1 & 2 & 3 & 4 & 5 & 6 & $\boldsymbol{\gamma}$ & 8 & 9 & 10 & 11 & 12 & 13 & 14 & 15 & 16 \\
\hline Art Institute of Chicago. & $\begin{array}{c}\$ 7,500- \\
\$ 8,500\end{array}$ & 0 & 0 & $\mathbf{0}$ & 2 & 0 & 5 & 7 & & & & & 0 & 0 & \\
\hline
\end{tabular}

ENGINEERING SOHOOLS

\begin{tabular}{|c|c|c|c|c|c|c|c|c|c|c|c|c|c|c|c|}
\hline $\begin{array}{l}\text { Armour Institute of Technology } \\
\text { Massachusetts Institute of Technology } \\
\text { Stevens Institute of Technology } \\
\text { Polytechnic Institute of Brookin } \\
\text { Rensselaer Polytechnic Institute } \\
\text { Case School of Applied Science } \\
\text { Carnegie Institute of Technology }\end{array}$ & $\begin{array}{r}\$ 450 \\
96,250 \\
8,500 \\
5,760 \\
17,550 \\
9,500 \\
14,000\end{array}$ & $\begin{array}{r}3 \\
210 \\
112 \\
0 \\
1 \\
0 \\
0\end{array}$ & $\begin{array}{r}0 \\
0 \\
0 \\
10 \\
21 \\
0 \\
0\end{array}$ & $\begin{array}{l}0 \\
0 \\
0 \\
0 \\
0 \\
0 \\
0\end{array}$ & $\begin{array}{r}0 \\
62 \\
0 \\
0 \\
0 \\
219 \\
0\end{array}$ & \begin{tabular}{r|}
0 \\
4 \\
0 \\
2 \\
12 \\
0 \\
28
\end{tabular} & $\begin{array}{l}0 \\
7 \\
2 \\
0 \\
0 \\
0 \\
0\end{array}$ & $\begin{array}{r}3 \\
283 \\
114 \\
12 \\
34 \\
19 \\
28\end{array}$ & $\begin{array}{r}0 \\
283 \\
114 \\
0 \\
34 \\
0 \\
0\end{array}$ & $\begin{array}{r}3 \\
0 \\
0 \\
12 \\
0 \\
19 \\
28\end{array}$ & $\begin{array}{r}3 \\
283 \\
112 \\
0 \\
134 \\
0 \\
28\end{array}$ & $\begin{array}{r}0 \\
0 \\
2 \\
12 \\
0 \\
19 \\
0\end{array}$ & $\begin{array}{r}3 \\
-114 \\
12 \\
34 \\
19 \\
28\end{array}$ & $\begin{array}{c}0 \\
-0 \\
0 \\
0 \\
0 \\
0\end{array}$ & $\begin{array}{c}0 \\
- \\
0 \\
0 \\
0 \\
0 \\
0\end{array}$ \\
\hline
\end{tabular}

MEDICAL SOHOOLS

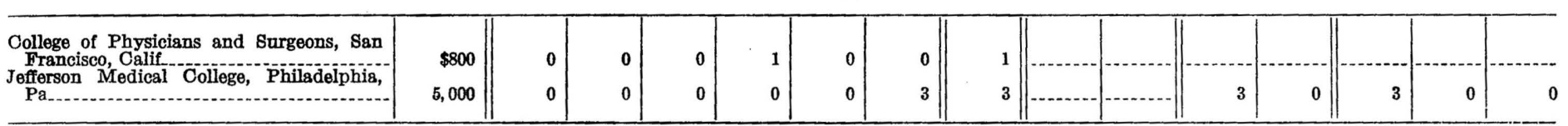

MUSIO SCHOOL

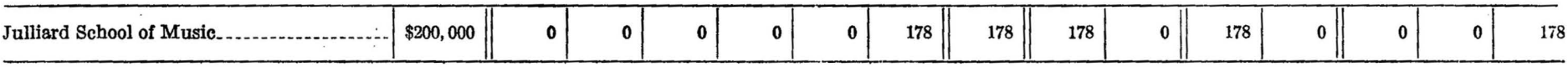


OSTEOPATHY SOHOOLS

\begin{tabular}{|c|c|c|c|c|c|c|c|c|c|c|c|c|c|c|c|}
\hline $\begin{array}{l}\text { Chicago College of Osteopathy } \\
\text { Kirksville College of Osteopathy and sur- } \\
\text { gery }\end{array}$ & $\begin{array}{r}\$ 840 \\
900\end{array}$ & $\begin{array}{l}6 \\
2\end{array}$ & $\begin{array}{l}0 \\
0\end{array}$ & $\begin{array}{l}0 \\
0\end{array}$ & $\begin{array}{l}0 \\
0\end{array}$ & $\begin{array}{l}0 \\
0\end{array}$ & $\begin{array}{l}0 \\
0\end{array}$ & $\begin{array}{l}6 \\
2\end{array}$ & $\begin{array}{l}0 \\
0\end{array}$ & $\begin{array}{l}6 \\
2\end{array}$ & $\begin{array}{l}6 \\
0\end{array}$ & $\begin{array}{l}0 \\
2\end{array}$ & $\begin{array}{l}0 \\
0\end{array}$ & $\begin{array}{l}0 \\
0\end{array}$ & $\begin{array}{l}6 \\
2\end{array}$ \\
\hline
\end{tabular}

PHARMAOY SCHOOLS

\begin{tabular}{|c|c|c|c|c|c|c|c|c|c|c|c|c|c|c|c|}
\hline $\begin{array}{l}\text { Massachusetts College of Pharmacy } \\
\text { Philadelphia College of Pharmacy and } \\
\text { Science- }\end{array}$ & $\begin{array}{r}\$ 8,000 \\
3,500\end{array}$ & $\begin{array}{l}0 \\
0\end{array}$ & $\begin{array}{r}0 \\
10\end{array}$ & $\begin{array}{l}0 \\
0\end{array}$ & $\begin{array}{l}0 \\
0\end{array}$ & $\begin{array}{l}5 \\
0\end{array}$ & $\begin{array}{l}4 \\
0\end{array}$ & $\begin{array}{r}9 \\
10\end{array}$ & $\begin{array}{l}0 \\
0\end{array}$ & $\begin{array}{r}9 \\
10\end{array}$ & $\begin{array}{r}0 \\
10\end{array}$ & $\begin{array}{l}9 \\
0\end{array}$ & $\begin{array}{l}9 \\
0\end{array}$ & $\begin{array}{l}0 \\
0\end{array}$ & $\begin{array}{r}0 \\
10\end{array}$ \\
\hline
\end{tabular}

SOHOOL OF SOCIAL WORK

\begin{tabular}{|c|c|c|c|c|c|c|c|c|c|c|c|c|c|c|c|}
\hline Graduate School of Jewish Social Work & $\$ 9,000$ & 0 & 9 & 0 & 3 & 1 & 0 & 13 & $\boldsymbol{\theta}$ & 4 & 0 & 0 & 0 & 0 & 13 \\
\hline
\end{tabular}

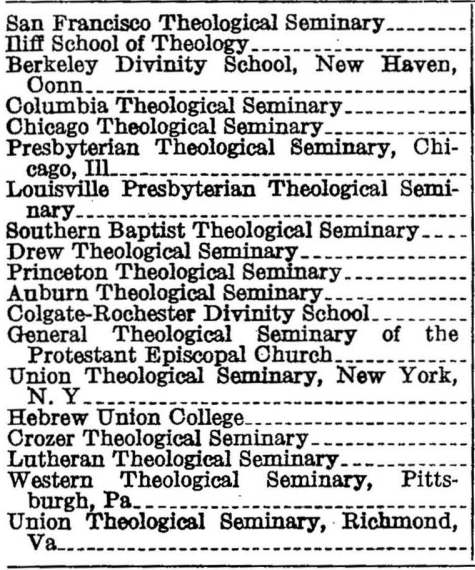

1 May be renewed

\begin{tabular}{r||r|r|r|r|}
\hline$\$ 700$ & 0 & 0 & 0 & 1 \\
500 & 0 & 0 & 0 & 1 \\
1,150 & 0 & 1 & 0 & 1 \\
7,000 & 2 & 0 & 1 & 0 \\
4,000 & 0 & 0 & 0 & 4 \\
3,500 & 0 & 0 & 0 & 0 \\
3,400 & 0 & 0 & 0 & 7 \\
\hline 4,000 & 13 & 0 & 0 & 0 \\
450 & 0 & 0 & 0 & 2 \\
3,200 & 0 & 0 & 0 & 0 \\
6,500 & 1 & 0 & 2 & 1 \\
8,400 & 0 & 0 & 0 & 0 \\
2,500 & 0 & 0 & 1 & 0 \\
1,100 & 0 & 0 & 0 & 1 \\
900 & 0 & 0 & 0 & 2 \\
800 & 0 & 0 & 0 & 0 \\
1,900 & 0 & 0 & 4 & 0 \\
\hline
\end{tabular}

2 Graduate assistants.

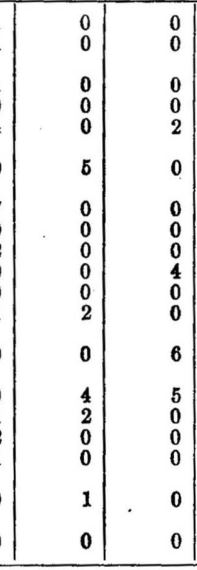

0

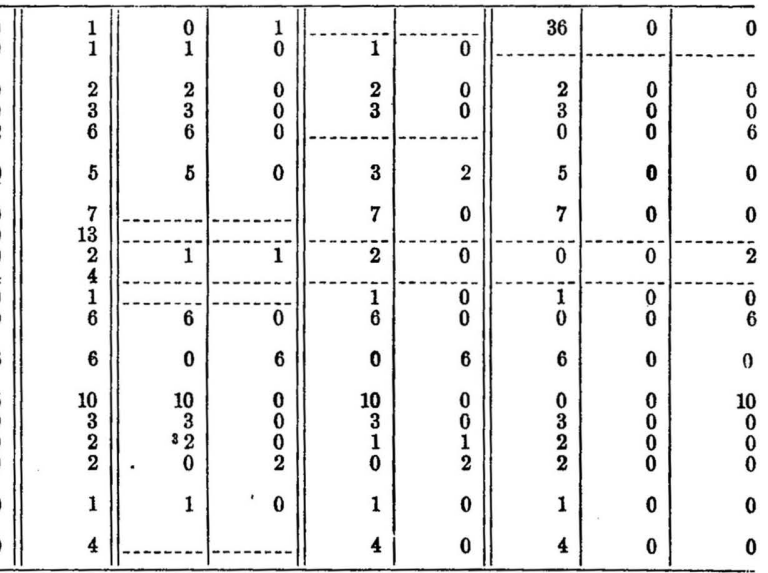

3 Carries a moral obligation to be repaid.

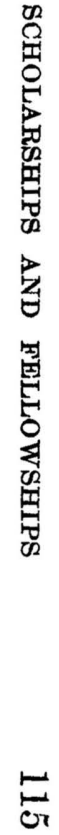





\section{APPENDIX}

\section{UNITED STATES \\ DEPARTMENT OF THE INTERIOR \\ OFFICE OF EDUCATION}

To the President of the University or College:

The U. S. Office of Education is now revising the study of Scholarships and Fellowships made in 1931 by Ella B. Rateliffe (Bulletin No. 15, 1931). In order that these aids may be correctly indicated for your institution, will you please answer the following questions for the current year and return the sheet in the enclosed return envelope, which requires no postage. Use approximate figures where actual amounts cannot be given.

Sincerely yours,

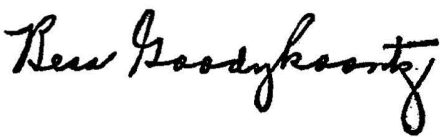

Assistant Commissioner.

1. Number of grants made annually for:

Scholarships: Less than $\$ 50$

Fellowships:

$\$ 0-299$

$\$ 50-99$

-..-.-.-.

300-399

100-149

-.........

$400-499$

150-199

500-749

200-249

-

750-999

250-299

- $-\cdots-\cdots-\cdots-1$

1000-1499

300-350

1500-2000

Over 350

-

Over 2000

Total

-...-.....-

Total

2. Total amount available annually for

\begin{tabular}{|c|c|}
\hline Scholarships & Fellowships \\
\hline & $\$ \ldots \ldots$ \\
\hline$\ldots$ & $\ldots \ldots$ \\
\hline & 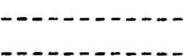 \\
\hline & - \\
\hline$\cdots$ & $\cdots-\cdots$ \\
\hline - & $-1--1,-1-1$ \\
\hline 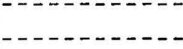 & 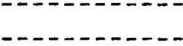 \\
\hline - & $\ldots$ \\
\hline$-1-1-1-1$ & $-\cdots-1$ \\
\hline$\ldots$ & -1 \\
\hline
\end{tabular}

6. If some grants are limited for study in subjects such as agriculture, English, history, medicine, please indicate on reverse side of this sheet the number of (a) scholarships and (b) fellowships limited to each department.

Date 






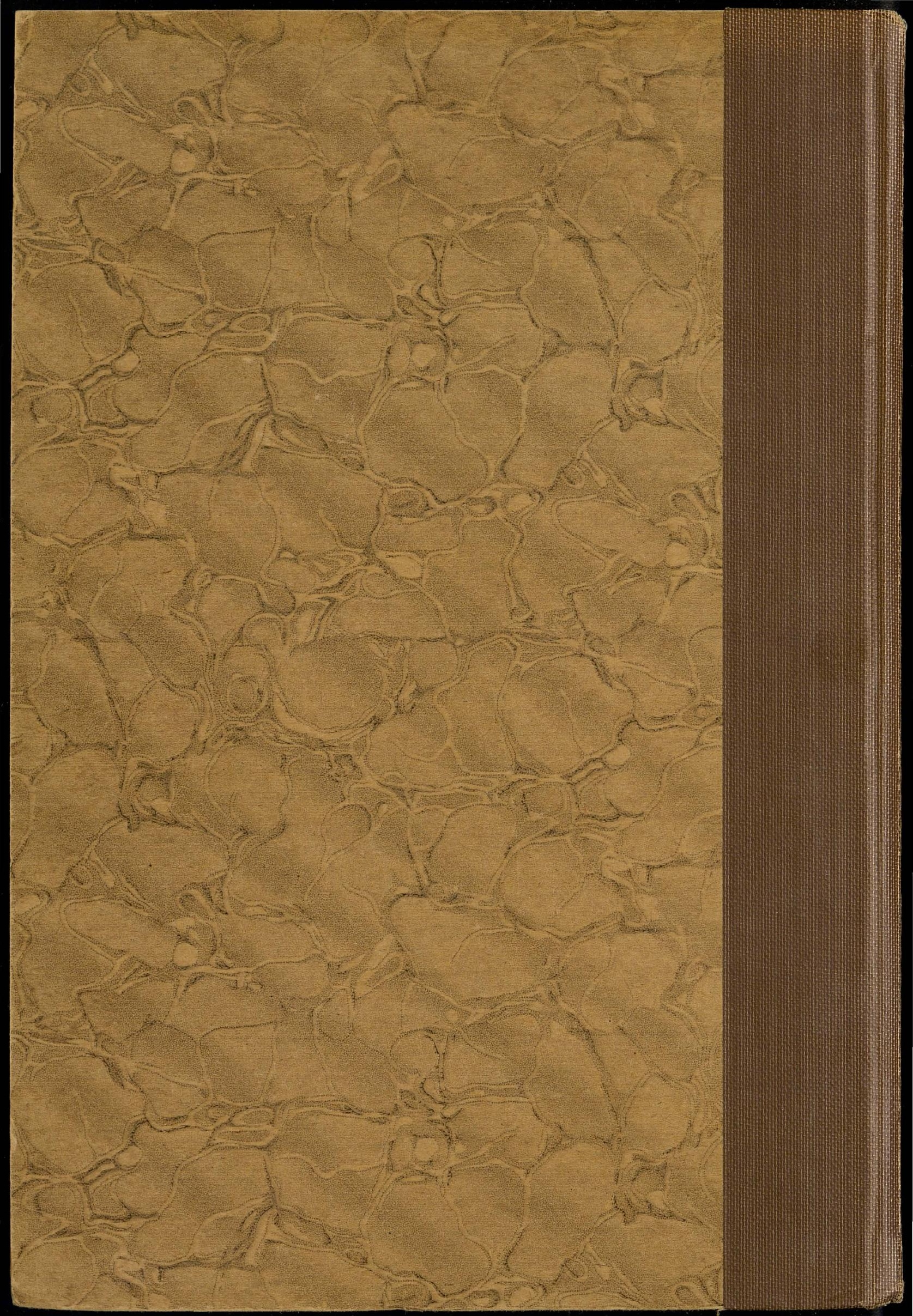

